Florida International University FIU Digital Commons

3-9-2012

\title{
(IN)Security of the Chosen People: Theological Foundations of Shi'a Strategic Culture
}

Sayed Amir Mirtaheri

Florida International University, s.amir.mirtaheri@gmail.com

DOI: $10.25148 /$ etd.FI12042314

Follow this and additional works at: https://digitalcommons.fiu.edu/etd

\section{Recommended Citation}

Mirtaheri, Sayed Amir, "(IN)Security of the Chosen People: Theological Foundations of Shi'a Strategic Culture" (2012). FIU

Electronic Theses and Dissertations. 579.

https://digitalcommons.fiu.edu/etd/579 


\section{FLORIDA INTERNATIONAL UNIVERSITY}

Miami, Florida

(IN)SECURITY OF THE CHOSEN PEOPLE:

THEOLOGICAL FOUNDATIONS OF SHI'A STRATEGIC CULTURE

A dissertation submitted in partial fulfillment of the

requirements for the degree of

DOCTOR OF PHILOSOPHY

in

INTERNATIONAL RELATIONS

by

Sayed Amir Mirtaheri

2012 
To: Dean Kenneth G. Furton

College of Arts and Sciences

This dissertation, written by Sayed Amir Mirtaheri, and entitled (In)Security of the Chosen People: Theological Foundations of Shi'a Strategic Culture, having been approved in respect to style and intellectual content, is referred to you for judgment.

We have read this dissertation and recommend that it be approved.

Nicholas Onuf

Thomas A. Breslin

Maria del Mar Logrono Narbona

Mohiaddin Mesbahi, Major Professor

Date of Defense: March 9, 2012

The dissertation of Sayed Amir Mirtaheri is approved.

Dean Kenneth G. Furton

College of Arts and Sciences

Dean Lakshmi N. Reddi

University Graduate School

Florida International University, 2012 
(C) Copyright 2012 by Sayed Amir Mirtaheri

All rights reserved. 


\section{DEDICATION}

To Maryam and Maseeh

with love. 


\section{ACKNOWLEDGMENT}

I would like to express my gratitude to my Dissertation Committee. I have been truly privileged to work with Dr. Mohiaddin Mesbahi, my Major Professor, in my $\mathrm{PhD}$ program. Throughout these years, I have learned extensively not only from his vast knowledge and his analytical methods in International Relations, but also from his extraordinary character and his amazing ability to sympathize with people of different backgrounds. My limited knowledge of International Relations has been shaped in important ways by Professor Mesbahi's analytical and intellectual approach. I cannot overstate my gratitude for his constant support, kindness and encouragement, and for his intellectual guidance that has brought this dissertation to fruition. Also, I would like to express my appreciation to the members of my Dissertation Committee, Professor Nicholas Onuf, Professor Thomas Breslin, and Professor Maria Logrono Narbona, for their support, interest and involvement in my work. Working with such distinguished scholars, great teachers and caring mentors has been an exceptional educational opportunity for me.

I must also recognize and thank for the help and support I have received from Professor Aisha Musa, who initially served as a member of my Dissertation Committee. I am grateful to Florida International University's Graduate School for awarding me the Dissertation Evidence Acquisition Fellowship and the Dissertation Year Fellowship without which writing this dissertation would have not been possible. I must also thank Carleton University in Ottawa and especially Professor Farhang Rajaee, the Director of the College of the Humanities at Carleton, for providing me with the access to the 
University's library facilities during the final stages of my writing in the summer and fall of 2011.

I am indebted to the intellectual guidance I have received from Professor Richard Bulliet, Professor Mohsen Kadivar and Professor Farhang Rajaee in the course of writing this dissertation. In addition, my sincere thanks go to the staff and faculty of the Department of Politics and International Relations at FIU for all their help and support throughout the past six years. In particular, I would like to recognize the kindness and thoughtfulness of late Professor Antonio Jorge, Professor Thomas Breslin, Professor Harry Gould, Professor Elisabeth Prugl, Professor Ralph Clem and Ms. Luz Aviles. Last but not least I am deeply grateful for the help and sacrifices of my parents, my wife, Maryam, and my brothers, Ahmad and Mohammad. 


\title{
ABSTRACT OF THE DISSERTATION \\ (IN)SECURITY OF THE CHOSEN PEOPLE:
}

\section{THEOLOGICAL FOUNDATIONS OF SHI‘A STRATEGIC CULTURE}

by

\author{
Sayed Amir Mirtaheri
}

Florida International University, 2012

Miami, Florida

Professor Mohiaddin Mesbahi, Major Professor

This dissertation explores the theological foundations of Shi'a strategic cultures within the theoretical framework of Neo-Traditionalism and rule-oriented Constructivism. In terms of methodology, it uses historical analysis based on mainstream Muslim historiographies, and discourse analysis of major classical Shi‘a texts. The dissertation identifies three Shi'a concepts of Shahādah, i.e. martyrdom, Taqīyyah loosely translated to precautionary concealment- and Wilāyah/Walāyah as the theological foundations of various Shi'a strategic cultures. While -mystical- Shahādah refers to "idealistic" metaphors in Shi'a Islam based on the story of Shi'a third Imām, Taqīyyah essentially refers to "commonsense counsel of caution." Shahādah provided the Shi'a community with a sense of metaphysical security through salvation when the community was deprived of prospects for social prosperity. It belittled physical pain and worldly defeat by emphasizing the ideal of fighting for justice. This also led to an essentially different understanding of Jihād in Shi‘a Islam compared to Sunnī Islam. In contrast to Shahādah, the doctrine of Taqīyyah was a proactive and pragmatic strategy chosen by Shi'a minority and aimed at survival. The doctrine of Taqiyyah highly valued 
the collective and individual survival of Shi ${ }^{`}$ a Muslims. It socialized them with a cautious attitude towards politics and towards state. The Aristotelian prudence embedded in Taqiyyah eventually became Shi'a modus vivendi for many centuries. Finally, the Shi'a ontology of Wilāyah/Walāyah refers to the exoteric and esoteric aspects of the metaphysical structure of the world through which the Grace of God is bestowed upon men according to Shi'a Islam. Wilāyah and Walāyah constituted one of the central points of distinction between Sunnī Islam and Shi`a Islam. At the same time, they socialized Shi'a Muslims with a sense of authority essential for the protection of a persecuted community. More importantly, however, they projected Shi'a community as the protectors of the "heart of Islam." This allowed the seemingly contradictory doctrines of Shahādah and Taqīyyah to coexist in Shi'a strategic thinking; for a "special community" were believed to be allowed to resort to special measures for its protection. 


\section{TABLE OF CONTENTS}

\section{CHAPTER}

PAGE

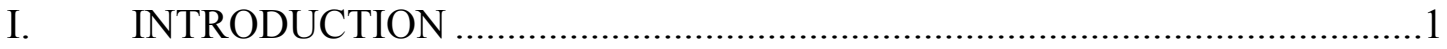

The General Context of the Research ….......................................................... 1

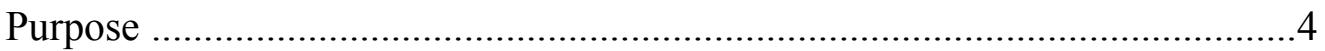

Research Questions and Dissertation Structure .........................................5

Theoretical Framework and Methodology ............................................... 18

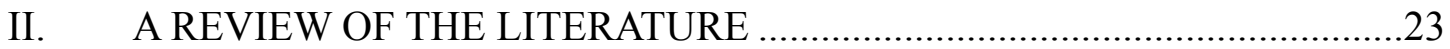

Introduction.......................................................................................2 23

International Relations: Religion and Secularism ....................................24

Security Studies: Islam and Strategic Culture ..........................................53

Shī'ah Studies: Shī'ah and Orientalism .................................................72

Dissertation Contributions .....................................................................98

III. SHAHĀDAH: METAPHOR OF AN IDEAL ............................................. 100

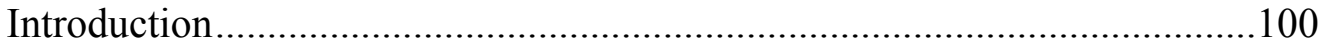

The Foundations of Shī' $\overline{1}$ Doctrine of Shahādah and Its Implications .........103

The Mystical Dimension of Shahādah .....................................................125

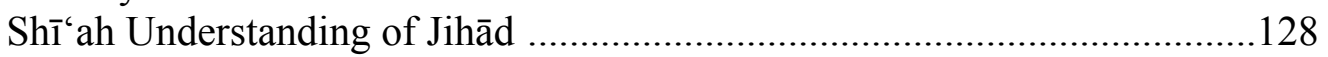

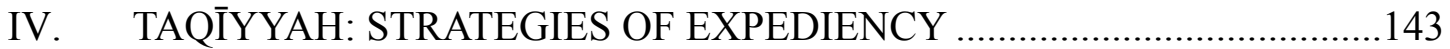

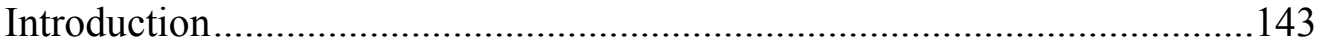

The Foundations of Shī'̄i Doctrine of Taqìyyah and Its Implications ...........145

Principled Action and Expediency: The Legacy of 'Alī .............................176

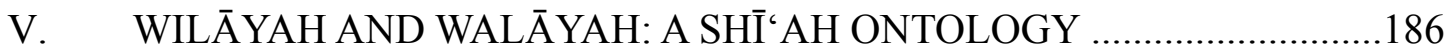

Understanding Wilāyah and Walāyah ....................................................186

Strategic Implications ........................................................................201

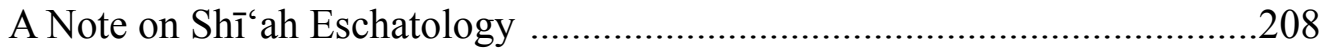

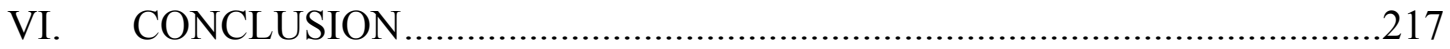

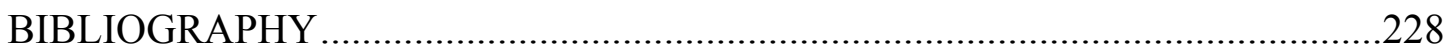

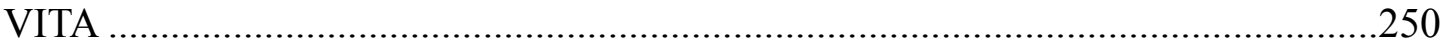




\section{CHAPTER I}

\section{INTRODUCTION}

\section{The General Context of the Research}

More than three decades ago, a throne that had seated kings for thousands of years crumbled in the face of a $\mathrm{Sh}^{-}{ }^{6} \mathrm{ah}^{1}$ revolution in Iran. Amidst the surprise of many observers, both inside and outside the country, a group of Shī'ah Muslims had achieved a noticeable strategic "success." The Revolution was soon dubbed the "Islamic" Revolution, which was reasonable to the extent that Shī'ah Islam is one of the two popular versions of the religion. Yet, the generic term "Islamic Revolution" tends to

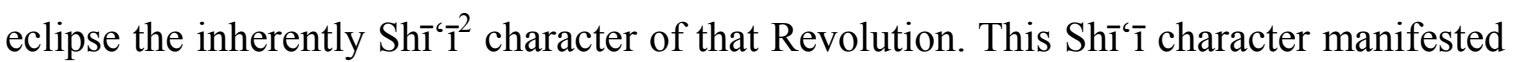
yet more in the political system that emerged after the Revolution in complex -and at times paradoxical- ways. As many scholars of Islam and Iran have noted, the Revolution in Iran and the following political system are but one of the many potential outcomes of Shī'ah history. It is not possible, in other words, to reduce an ancient non-homogenous tradition to merely three decades of political experience. Yet, the Revolution and the thus far viable political system that followed it are among the main reasons for the production of studies such as this one.

The unexpected "success" of Ayatollah Khomeini in establishing an "Islamic state" becomes more challenging to explain when one compares Khomeini's political accomplishments with those of his counterparts in the Sunnī world. Even two decades

\footnotetext{
${ }^{1}$ Throughout this dissertation, I have generally used ALA-LC transliteration system for Arabic terms, names, titles and phrases. For Arabic words that have been Latinized, I have used the most common -or one of the most common- English version(s).

${ }^{2} \operatorname{Sh}^{\top}{ }^{\top} \overline{1}$ is the adjective form of the noun Shī‘ah.
} 
after his death, Ayatollah Khomeini's political "victory" remains unparalleled among the Muslim aspirants of politicized Islam. Except for the notable exception of the ill-fated Taliban state in Afghanistan, prominent advocates of "political Islam" in the Sunnī world have either failed to establish an "Islamic state" or have chosen not to pursue such an objective. In stark contrast, an obscure Ayatollah toppled one of the oldest royal systems in the world to establish the first "Shī'ah Republic." Meanwhile, in Sunn̄ Arab Middle East, secular Arab nationalisms of the Nasser era -with its socialist undertone- were shattered by the repeated defeat of Arab national armies at the hand of Israeli military forces. The subsequent religious backlash to that secular project generally failed to succeed as long as it adhered to its rigid ideological tenets. The lack of "success" was despite the forceful emergence of Mujahedeen in Afghanistan and their military achievements. Mujahedeen did take credit for bringing down one of the two superpowers. Their sympathizers in the Sunnī Arab world, however, failed to bring down a single -and much weaker- Arab dictator. In contrast, the recent wave of uprisings in the Arab world during the "Arab Spring" succeeded with much ease and rapidity in toppling down a series of dictators. The success can be attributed to a variety of complex causes. Yet, radical forces of "political Islam" seem to be receiving a small share of the credit for the success. Recent Arab uprisings differed markedly, both in their form and in their objectives, from the type of social movements that ideologists of older generations including Khomeini would wish.

Similar to Ayatollah Khomeini, radical Sunnī ideologists fiercely challenged the conservative and mostly pro-West dictators and kings in various Arab countries, yet to no avail. The long record of their repeated defeat forced many of them to abandon -or at 
least tone down- political struggle and a few of them to go underground. The resulting environment did indeed allow for a new younger generation of activists to emerge and surprise the world in 2010. The failure of Sunnī ideological movements in the past decades also led to the birth of terrorist organizations such as Al-Qaeda. These organizations were, in part, the result of a radicalizing political environment that denied meaningful forms of political participation -participations that would have arguably marginalized some of the radical voices.

There is the notable exception of Taliban reign in Afghanistan. A peculiar combination of superpower engagements during the Cold War and socioeconomic factors created an environment fertile for a Sunn̄̄ radical group to seize power -and to marginalize almost any other voice in the country. Yet, the experience proved an unviable one. Taliban was not remotely as competent as their western neighbor in defying the United States and in maintaining their hold on power. The contrast begs the question of why Shī'ah ideologists succeeded in toppling arguably one of the most powerful kings in the world, establishing a new political order, surviving one of the longest and most brutal wars of the past century, and withstanding the constant pressure from the international order.

My dissertation aims at contributing to better understanding of the root causes of the contrast between Shī'ah and Sunn̄̄ politics. It does so by applying the notion of strategic culture in the context of Security and Strategic Studies. The notion of strategic culture tries to captures the foundational socio-cultural themes that shape a country's, a nation's, or a people's strategic and security behaviors. It asks what historical, 
geographical, social and political trajectory a group of people have had to endure. ${ }^{3}$ On the basis of the answers to this question, strategic culture studies strive to understand and explain the actions and reactions of the people in question through a "general framework." It must be noted, however, that in the present dissertation, strategic culture is not considered as a substitute for material forces. It is, instead, assumed that such material factors have been translated into certain cultural practices and belief systems. These beliefs and practices have in turn affected material realities. The strategic culture of a people, in other words, may be understood as a "compressed story" of the -lived, projected and/or imagined- experiences of those people throughout history, as much as such compression may be possible.

\section{Purpose}

The main purpose of my $\mathrm{PhD}$ dissertation, therefore, is to better understand the basic tenets of Shī`î strategic cultures. It looks into Shī‘ah theology and history to understand how the minority Shī'ah community understood its existence vis-à-vis the majority Sunnī world; and how such understanding was translated into Shī‘̄ì strategic doctrines. These doctrines have had enduring effects in Shī‘i conceptualizations of the notions of security and threat. ${ }^{4}$ Conceptualizations of security among Shī ah Muslims

\footnotetext{
${ }^{3}$ Linking the question of strategy to the notion of culture -and that of identity- is one of the results of postCold War questions and challenges in Security Studies. The contributions of the "Copenhagen School" of Security Studies are particularly relevant here. See, for instance, Buzan, B., Wæver, O., \& de Wilde, J. (1998). Security: A New Framework for Analysis. Boulder: Lynne Rienner Publishers; and Williams, Michael C. (2007). Culture and Security: Symbolic Power and the Politics of International Security. New York: Routledge.

${ }^{4}$ The author acknowledges that using rather general terms such as "Shī'ah Islam" and "Shī'ah Muslims" might be problematic. There is a considerable diversity among Shi' 'ah Muslims and this study does not assume the existence of a singular homogenous Shī'ah Islam. Taking such diversity of experiences and doctrines into account, the research aims at identifying the influential yet common perceptions and doctrines -partially- shaping political behaviors of Shī'ah communities throughout history.
} 
bear a close relation to their treatments of the notion of justice and the institutions of political power. It is, therefore, consequential in $\operatorname{Sh}^{\top}{ }^{`} \overline{1}$ understandings and implementations of social movements on the one hand, and those of state and sovereignty on the other. Given the above context, the study serves as a bridge between the political theology of Shī'ah Islam, its political history, and Security Studies literature in International Relations.

\section{Research Questions and Dissertation Structure}

In tackling the question of Shī ${ }^{`}$ ah strategic cultures, the primary question is which concepts have been central in shaping Shī'ahs' worldview when it comes to their existence. What constitutes, in other words, the "philosophy of existence" for Sh``ah Muslims. Inquiring about Shī‘ $1 \overline{1}$ "philosophy of existence" will allow us to better understand the notions of security, survival, and threat as understood by Shī'ahs, for it is this philosophy that provides Shī‘ah Muslims with deeper-than-instinct answers for why the community needs to protect its survival.

After careful review of historical and theological sources in Shī ah Islam, the study identifies three central concepts upon which Shī'î strategic cultures rest. These are -in the order of presentation in this dissertation- the doctrine of Shahādah (i.e. martyrdom), the doctrine of Taqiyyah -or so-called "expedient concealment," and the foundational notions of Wilāyah and Walāyah. ${ }^{5}$ The three concepts are not equal in terms

\footnotetext{
${ }^{5}$ The words Wilāyah and Walāyah come from the same Arabic root $w-l-y$, which has various meanings. The word Wilāyah usually means "sovereign power," "rule," and "authority." The word Walāyah generally means "to be a friend," "friendship," and "guardianship." In Shī'ah theology, Wilāyah and Walāyah respectively refer to external and internal aspects of the "metaphysical structure" of the universe around which the world is organized, and through which the Grace of God is believed to be bestowed upon man. See Chapter V for more discussion.
} 
of the emphases laid upon them in Shī'ah theology. ${ }^{6}$ The first two, however, appear as parallel forces throughout history. The two were to balance Shī'ah Muslims' aspirations for their ideals on the one hand and their often dreadful and unfavorable material conditions on the other. Before a brief discussion of these two, however, it is worth paying attention to the notions of Wilāyah and Walāyah upon which the first two doctrines rest.

If one is asked to squeeze the "philosophy of existence" -or raison d'être- of Shī'ah Muslims into one concept, there is arguably no better answer than the dual notions of Wilāyah and Walāyah. Chapter V will include a more comprehensive study of the two concepts, the literal meanings of the terms, as well as their nuanced differences. For the purpose of introduction, however, it suffices to say that Wilāyah and Walāyah respectively refer to the external and internal aspects of a uniquely $\mathrm{Sh}^{\mathrm{i}}{ }^{‘} \overline{1}$ ontology. ${ }^{7}$ Walāyah refers to a "metaphysical structure" through which the Grace of God is bestowed upon men. Accordingly, there must always exist "infallible" saints who are carriers of Walāyah and who are the "metaphysical centers" of the universe. Shī'ah Muslims maintain that the line of these "holy bearers of Walāyah" goes back to Adam. After Adam, the most prominent "bearers of Walāyah" were the prophets, though the

\footnotetext{
${ }^{6}$ As will be discussed later, neither Shahādah nor Taqīyyah are central theological notions in Shī‘ah Islam. In contrast, Wilāyah and Walāyah are foundational notions in Shī'ah theology; and they are closely associated with the Shī'ī principle of imamate. In comparison, Shahādah and Taqīyyah may be considered as secondary theological notions, which appear on the list of subjects in various theological works of Shī'i authors.

${ }^{7}$ It must be noted that Shī'ah Muslims and -Shī‘ah and non-Shī'ah- Sūfiss are similar in their emphasis

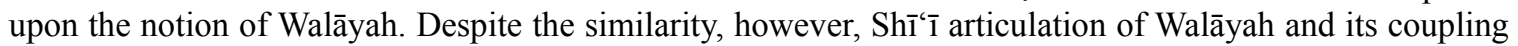
with Wilayah - as well as their clear emphasis on the role played by the immediate family of the Prophet in connection to both Wilāyah and Walāyah- constitute a unique version of the two concepts. See Chapter V for more discussion.
} 
honor was not exclusive to them. Following the death of Prophet Muhammad, the "seal of the prophets" according to Islam, the line of prophecy was broken indefinitely. In order to compensate for the absence of the prophets as the categorical "bearers of Walāyah," Shī'ah Muslims turned to the Prophet's direct descendants from his daughter, Fātịmah bint Muhammad. ${ }^{8}$ Twelve individuals, according to majority of Shī'ah Muslims, were recognized as the "bearers of Walāyah" and the channel via which the Grace of God was -and has been- distributed throughout men. These individuals are called Imām by Shī‘ah Muslims. ${ }^{9}$ Without such "bearers of Walāyah," Shī'ah Muslims believe, the world would not exist for the simple reason that its existence hinges upon the Divine Grace. ${ }^{10}$

At the same time, the highly esoteric and mystical notion of Walāyah was paralleled with a more mundane notion of Wilāyah, which refers to exoteric authorities. With such powerful "inner and universal authority" bestowed upon the "bearers of Walāyah," it was only reasonable for Shī'ah Muslims to believe that, more than anyone

${ }^{8} 605-632$ C.E.

${ }^{9}$ For more information on Shī'ah Islam and the Shī‘ah Imāms, see Țabāṭabā’̄̄, Sayyid Muhammad Ḥusayn. (1975). Shi 'ite Islam. Trans. S. H. Nasr. Albany: State University of New York Press. A useful collection of articles can also be found in Nasr, S. H., Dabashi, H., \& Nasr, S. V. R. (Eds.). (1989). Expectation of the Millennium: Shi 'ism in History. Albany: State University of New York Press.

${ }^{10}$ According to Shī'ah sources, following the death of the eleventh Imām, the line continued in a miraculous fashion. His young son, the twelfth Imām, went into "Occultation"; and ever since, he is believed to continue functioning as the "bearer of Walāyah" indirectly. According to the doctrine of Occultation, the twelfth Imām, Muhammad ibn Ḥasan -also known by his epithets al-Mahdī and al-Qā'im (b. 868 C.E.)- will return at the end of the world. It is by his death that, due to the final closure of the line of the "bearers of Walāyah," the world is believed to come to an end. This means that in Shī'ah Islam, the central notion of Walāyah is directly connected to Shī'ah eschatology. A brief discussion of Shī'ah eschatology and the doctrine of the "hidden Imām" is offered in Chapter V in relation to the general framework of this dissertation. For more information, see Sachedina, Abdulaziz A. (1981). Islamic Messianism: The Idea of the Mahdi in Twelver Shi ism. Albany: State University of New York Press; Modarresi Tabatabaii, Hossein. (1993). Crisis and Consolidation in the Formative Period of Shi 'ite Islam: Abu Ja'far Ibn Qiba Al-Razi and His Contribution to Imamite Shi'ite Thought. Princeton: Princeton University Press; and chapter 2 in Nasr, S. H. et al (Eds.). Expectation of the Millennium. 
else, these "holy people" have the right to external authority. In matters of judiciary and governance, who else could fulfill the duties better than the "bearers of Walāyah," they asked. Therefore, the Imāms appeared as the best candidates for ruling Muslim society. The logical extension of inner Walāyah into external Walāyah proved to be consequential in Shī'ī understanding of legitimate political power, and later on its uncomfortable and half-hearted accommodation of the modern state; for implicit in the attribution of Wilāyah to the Imāms was the conclusion that any other political power is an unjustified and, therefore, despotic rule. In fact, the strong anti-political-power drive in Shī'ah Islam has its roots in the above theological argument. Some of the implications of this drive will also be discussed throughout this dissertation and especially in relation to the central principle of justice in Shī'ah Islam. More specific implications of the notions of Wilāyah and Walāyah -for instance in regards to the modern nation-state- are beyond the scope of this dissertation and other scholars have written extensively on those subjects. ${ }^{11}$

Before turning to the two doctrines of Shahādah and Taqīyyah and their relations with the ontology of Wilāyah and Walāyah, it is useful to review the principle of justice in Shī'ah Islam in an introductory fashion. Justice seems to have been among the universal concerns of men. Yet, one may observe an acute attention to the principle of

\footnotetext{
11 The far-reaching impacts of Shî'ah political theology on the modern institution of the nation-state became clear to me through a series of extensive interviews with Professor Mohiaddin Mesbahi during Fall 2008.

As the reader will find throughout my dissertation, I have extensively benefited from Professor Mesbahi's insightful comments, feedback, and analyses on numerous occasions. This has been the result of my extensive interviews with Professor Mesbahi between Spring 2008 and Spring 2012, as well as his lectures in various graduate seminars including his graduate seminars on Islam in International Relations (Spring 2007) and on Security and Strategic Studies (Fall 2007). From this point, I will refer to Professor Mesbahi's comments and analyses by using $\underline{\mathrm{M}}$. Mesbahi, Interviews or M. Mesbahi, Lectures depending on the category.
} 
justice, its value, and its implications among minority communities. Such an attention is clearly the case for Shī'ah Muslims. Their emphasis on justice, or 'Adl, might indeed be a reflection of their harsh and bleak social history. Being a small minority within an antagonistic Sunnī majority and living for centuries under the threat of persecution by Sunnī rulers, Shī'ah theologians turned to the question of justice for two interrelated reasons: explanation and hope. They expounded upon the notion of Divine Justice and elevated it as one of the "five pillars" of Shī'ah Islam. ${ }^{12}$ Divine Justice was to provide desperate Shī'ah Muslims with a big-picture understanding of the world in which their current misery and plights were but a passing and temporary phase. The big picture, they argued, was at the end essentially just and undeniably good -despite "short periods" in which the evil surpassed the good. Divine Justice also provided Shī'ah Muslims with a promise of the ultimate salvation from internal and external calamities. For these reasons, justice appears heavily in Shī'ah eschatology to the extent that the end of times is marked by the "triumph of justice over injustice." Furthermore, 'Alī ibn Abī Țālib ${ }^{13}$, the first Shī'ah Imām and the second most venerated figure in Shī'ah Islam, is often seen as the epitome of justice and just ruling by Shī'ah Muslims. ${ }^{14}$ Throughout history of Shī'ah Islam, 'Alī has been seen as the role-model for rulers and kings. These kings have often

\footnotetext{
${ }^{12}$ Along with Divine Justice , or al- 'Adl, the "five pillars" are the doctrines of Unity -al-Tawhīd-, afterlife -al-Ma'ād-, prophet-hood -al-Nubuwwah-, and imamate -al-Imāmah. Note that imamate in Shī'ah reading refers to the status of the descendants of the Prophet and their possession of Wilāyah and Walāyah. The term, therefore, has quite different connotations in Shī‘ah and Sunnī Islams.

${ }^{13} 600$ - 661 C.E. He is also known by his epithet Amīr al-Mu'minīn. From this point, wherever the single name 'Alī is used in this dissertation, it refers to 'Alī ibn Abī Ṭālib.

${ }^{14}$ For a short period of time, 'Alī reigned as the Muslim caliph. In fact, he is the fourth Sunnī caliph and the last of the "Four Rightly Guided" caliphs according to Sunnī Muslims. His caliphate was marked by internal turmoil in the Muslim world and several civil wars, which eventually led to the assassination of 'Ali by an extremist Muslim group. The assassination paved the way for the rise of the Umayyad dynasty.
} 
been exhorted by Shī'ah community to follow 'Alī's example of just rule; even though the mainstream Shī'ah belief holds that all rulers will eventually fail to live up to 'Alī's high standards. Shī'ah narration of 'Alī's life and rule becomes so idealistic that it is difficult to imagine an ordinary person equaling him in piety or in justice. Although the emphasis on justice in Shī'ah Islam goes beyond the above examples, they seem to sufficiently convey the point. Given the importance of justice in Shī'ah Islam, I have discussed -directly or indirectly- its implications for Shī's̄ strategic cultures throughout the dissertation.

One of the central doctrines shaping $\operatorname{Sh}^{\mathbf{1}}{ }^{‘} \overline{1}$ strategic cultures is the doctrine of Shahādah or martyrdom. ${ }^{15}$ Much has been written on martyrdom in Islam and in Shī'ah Islam. The large body of literature has contributed to better understanding of the Shì' ${ }^{-} \overline{1}$ understandings of martyrdom. At the same time, certain mistakes in reading the $\mathrm{Sh}_{\overline{1}}^{-} \overline{1}$ doctrine of Shahādah have caused common misunderstandings. These misunderstandings have been exacerbated following the terrorist attacks of September 11, 2001. As a result, there is a tendency among some writers to lump the ancient and complex doctrine of Shahādah in Shī'ah Islam together with the modern phenomenon of suicide killing. One of the root causes of these misunderstandings has been a confusion of Sunnī understanding of external Jihād -or holy exertion- with its Shī' $\overline{1}$ understanding. Here, the principle of justice and its priority for Shī‘ah Muslims appear once again. In Sunn̄̄ discourses, the notions of Jihād and martyrdom are associated with the Prophetic tradition of wars with the "infidels" for the "spread of Islam.” In Shī‘̄i discourses, however, Jihād

\footnotetext{
15 The centrality of the doctrine of Shahādah in Shī' $\overline{1}$ strategic thinking became clear to me through my interviews with Professor Mesbahi [M. Mesbahi, Interviews, Fall 2008].
} 
and martyrdom are closely associated with the third Shî‘ah Imām's ${ }^{16}$ battle with another group of Muslims in his efforts to "protest against injustice." It must be noted that Shī'ah jurists have often followed the examples of Sunnī jurists in understanding external Jihād as fighting with the "infidels." Yet, their legal writings diverged from Shī‘ī popular discourses on Jihād for two reasons. One was the geography of Shī‘ah Muslims that allowed only limited encounters with the so-called "infidels." For the most part, Shī'ah Muslims lived in enclaves surrounded by a larger Sunnī community who were not -at least technically- "infidels." As such, the idea of "Jihād with infidels to spread Islam" was irrelevant. The other reason has been the history of Sh'`‘ ah Muslims' access to power. During the formative centuries of Shī`ah Islam, Shī`ah Muslims had no or limited access to power -and sovereignty. The limited access prevented them from any meaningful engagement in wars with "infidels." Following the death of the Prophet, it was mainly the first three Sunnī caliphs -and specially the second caliph, 'Umar ibn al-Khațāāb- who engaged in territorial expansion of Muslim world. The early caliphs, in other words, did militarily engage the "infidels" and needed judicial codebooks for the conduct of external Jihād. Mainstream Shī‘ī beliefs, however, held the legitimacy of the reign of the first three caliphs -as well as their acts of war and peace- in question. In contrast, the short reign of the fourth caliph and the first Shī'ah Imām, 'Alī, was generally colored by internal conflicts and civil wars to such an extent that no major incidence of engagement with the "infidels" occurred. Following the assassination of "Alī, the rise of the Sunnī Umayyad and Abbasid dynasties meant a long period of inferiority for Shī‘ah Muslims.

\footnotetext{
${ }^{16}$ The third Shī'ah Imām is Husayn ibn 'Alī (626 - 680 C.E.), who was also a grandson of the Prophet. He is known by his epithets Abā 'Abd Allāh and Sayyid al-Shuhadā'. From this point, wherever the single name Husayn is used in this dissertation, it refers to Husayn ibn 'Alī.
} 
During the aforementioned period, it was generally the Sunnī Muslims who were the conquerors and the empire-builders. ${ }^{17}$ In response, Sunnī jurists had to come up with elaborate and complex codes of conduct concerning external Jihād -with "infidels"- and concerning its aftermath. Many of these codes were later on found their ways into the writings of Shī'ah jurists, even though Shī'ah Muslims had more limited encounters with the "infidels." 18

In general, early Shī'ah jurists’ replicating the codes of external Jihād from their Sunnī colleagues has had limited relevance to Shī'ah community; for the prime metaphor of martyrdom in Shī'ah Islam came from the death of the third Imām, Husayn. ${ }^{19}$ As mentioned before, his martyrdom did not happen in a Jihād with the "infidels." Instead, it was a group of fellow Muslims who slaughtered Husayn and his companions and imprisoned the survivors. What has made Husayn's battle an "exemplary Jihād” in Shī'ah Islam -and his martyrdom a "supreme act of sacrifice"- was his struggle against “injustice.” Husayn’s martyrdom has left a profound imprint on Shī‘ah collective consciousness. There is arguably no other single incidence in the history of Shī'ah Islam that can be compared with what happened in Karbalā in 680 C.E. For over a thousand years, Shī'ah Muslims recognize the anniversary of his martyrdom with processions and

\footnotetext{
${ }^{17}$ See, for instance, Bennison, Amira K. (2009). The Great Caliphs: The Golden Age of the 'Abbasid Empire. London: I.B.Tauris \& Co. This is, of course, not to dismiss the important Shī'i contributions during this period or the so-called "Shī'ah century" from 945 to 1055 C.E. [Ibid. p. 45]. See also Piscatori, James. (1986). Islam in a World of Nation-States. Cambridge: Cambridge University Press.

${ }^{18}$ See Faghfoory, Mohammad H. (forthcoming April 2012). Ethic of War and Peace in Shi'ite Islam. In G. M. Reichberg \& H. Syse (Eds.), Ethics of War and Peace in World Religions. Cambridge: Cambridge University Press.

${ }^{19}$ Husayn and a number of his close companions were killed in 680 C.E. in Karbalā [see Ṭabātabā̄̄̄, Sayyid Muhammad Husayn. Shi ite Islam. pp. 196-200; and Nasr, S. H. et al (Eds.). Expectation of the Millennium. pp. 45-57].
} 
mourning while remembering the "extreme injustice" committed against the "Master of the Martyrs.",20

In regards to the study of Shì ${ }^{-} \overline{1}$ strategic cultures, the story of Husayn created an important conceptual framework. A central question in studying a people's strategic culture is whether they have specific conceptualizations of the notion of security in contrast to others. For Shī'ah Muslims, Husayn’s martyrdom has served as a metaphor of security throughout the centuries. The metaphor, of course, is a peculiar and somewhat paradoxical understanding of security; for by all worldly and material measures, Husayn failed in his -political or otherwise- quest. Most of his companions were killed and the remaining members of his family had to go through a long journey of humiliation at the hands of their captors. Yet, Shī'ah Muslims found in such utter insecurity and pain inflicted upon Husayn a foundation for their understanding of security. While Chapter III deals with this issue in more detail, the gist of the Shī' $\overline{1}$ attitude was to view Husayn's martyrdom as the "ultimate salvation" -leading to a sense of permanent and "metaphysical security" unachievable through any other means. The utmost insecurity of death at the hand of an unjust oppressor was deemed the source of greatest security. The above Shī's understanding of security is clearly articulated in the response that Husayn's surviving sister, Zaynab bint 'Alī' ${ }^{21}$, gave to the Umayyad caliph, Yazīd ibn $\mathrm{Mu}^{\text {'āwīyah }}{ }^{22}$.

\footnotetext{
${ }^{20}$ One of the epithets of Husayn among Shī'ah Muslims is Sayyid al-Shuhadā' meaning the "Master of the Martyrs." Originally, the exalting epithet belonged to Hamzah ibn 'Abd al-Mutallib, the Prophet's beloved uncle and companion, who had been killed in 625 C.E. in the Battle of Uhud. Shī'ah Muslims still use the title of "Master of the Martyrs" in reference to Hamzah ibn "Abd al-Muṭallib, albeit rarely.

${ }^{21}$ d. 682 C.E.

${ }^{22}$ d. 683 C.E.
} 
Following the Battle of Karbalā, when Zaynab bint 'Alī and other prisoners of war entered Yazīd ibn Mu‘āwīyah's court in Damascus, Yazīd ibn Mu‘āwīyah inquired Zaynab bint 'Alī about the sufferings and humiliations she and her family had to go through. In doing so, Yazīd ibn Mu'āwīyah also implied the fall of the prisoners from the Grace of God. Reportedly, Zaynab bint 'Alī responded that "[in what we have endured] I did not behold anything but of great beatitude.",23

In the centuries following the Battle of Karbalā, Shī'ah Muslims went through a long period of external insecurity and socioeconomic pressure. It is not surprising, therefore, that they saw the story of Husayn as an extreme version of their own difficult condition; and that they sought relief in remembering the "ultimate sacrifice" of Husayn. The story, despite its tragic and sorrowful quality, appeared as a story of hope. It sanctioned a belief that the utmost insecurity will eventually turns into ultimate and blissful salvation. It was understood as the fulfillment of the Qur'ānic repeated promises $^{24}$ that with each period of difficulty, there shall be a time of comfort -even though such comfort may come after death.

In the formative period of Shī'ah Islam, therefore, the notions of Shahādah and Jihād were developed differently by Shī'ah Muslims compared to their Sunn̄̄ coreligionists. During the same period, a more pragmatic and practical doctrine of expediency also appeared due to the forces of reality. The doctrine was called the doctrine of Taqīyyah - often loosely translated to "precautionary concealment." Compared to the

\footnotetext{
${ }^{23}$ The words of Zaynab bint 'Alī has been reported in various Shī'‘̄ sources including 'Allāmih Majlisī, Biḥār al-Anwār, Vol. 45, p. 116.

${ }^{24}$ See the Qur'ān 94:5 and 94:6.
} 
doctrine of Shahādah, the doctrine of Taqiyyah was a more proactive response to the hostile environment. The elaborate theological Shī's edifice around the notion of Shahādah emerged partly as a reaction to a sociopolitical landscape that seemed to offer no prospect of security for Shī'ah community. In response, religious leaders of the community took refuge in the notion of "metaphysical security" epitomized in Shahādah. This is not to deny the grounds of Shahādah as a "religious act" in -Shī'ah- Islam. Rather, it is to argue that the rise of Shahādah -and the accompanying accommodation of pain and suffering- in collective consciousness of Shī'ah community was in part a reaction to social realities.

In contrast, Taqīyyah was a proactive and finely calculated strategy by a persecuted people. The word has often been translated as "precautionary concealment" or "cautionary dissimilation," which is not precise -although they do convey one of the commonly understood implications of the term. The more detailed discussion of the meanings and implications of the term will be presented in Chapter IV following the seminal contribution of the late Professor Hamid Enayat. ${ }^{25}$ For the purpose of introduction, however, it must be said that the term Taqiyyah refers to "commonsense 'counsel of caution'."26 The underlying principle behind Taqīyyah is close to Aristotelian prudence. ${ }^{27}$ As such, Taqīyyah was a call for caution, deliberation, and sound judgment

\footnotetext{
${ }^{25}$ See Enayat, Hamid. (1982). Modern Islamic Political Thoughts. Austin: University of Texas Press.

${ }^{26}$ See Ibid. p. 175.

${ }^{27}$ The notion of prudence at the heart of the doctrine of Taqiyyah became clear to me through my personal communications with Professor Mohsen Kadivar during September 2010. I am also indebted to Professor Farhang Rajaee for an insightful conversation regarding the notion of prudence in Aristotle's political philosophy and in Taqīyyah [F. Rajaee, personal communication, July 7, 2011]. For an insightful discussion of prudence within a different religious context, see Bireley, Robert. (1990). The Counter-Reformation Prince: Anti-Machiavellianism or Catholic Statecraft in Early Modern Europe. Chapel Hill: University of
} 
among members of a persecuted minority. The doctrine valued the survival of the Shi' ${ }^{`} a h$ community as well as Shī‘ah individuals. Furthermore, the drive for survival went beyond natural instinct and was, implicitly or explicitly, linked to Shī'ah "philosophy of existence" -i.e. Wilāyah and Walāyah. If one can view one's community as a "chosen community" in the sense of receiving the Grace of God, one can feel a strong religious duty to protect the community's survival too.

The introduction of the doctrine of Taqīyyah by Shī'ah Imāms had immediate consequences for the Shī‘ah community and its security. According to Shī‘ah Muslims, the principle of prudence was observed by 'Alī in his long period of political silence during the reign of the first three caliphs, whom mainstream Shī'ah Muslims came to regard as illegitimate successors to the Prophet. Yet, it was after the catastrophic events of Karbalā and the slaughters of their third Imām that Shī'ah community began to reflect more on the notions of prudence and expediency. The Battle of Karbalā evinced, inter alia, the extremely precarious hold of Shì ah community on survival. If the highly venerated and respected grandson of the Prophet were not spared, who would, Shī'ah Muslims asked. Thus, at the same time that Shī'ah community began to nurture a passionate love for Husayn and his "ultimate act of worship," they also devised a strategy of survival. The strategy was further elaborated upon by the subsequent Shī'ah Imāms. More important than their words, however, the principle of prudent action was manifested in the behaviors of these later Imāms. Unlike their predecessor, Husayn, they often treated matters of politics with extreme caution. ${ }^{28}$ They even treated the avengers of

\section{North Carolina Press.}

${ }^{28}$ Although this claim generally applies to most of the Shī'ah Imāms who followed Ḥusayn, there are few 
Husayn with alertness refusing to openly and actively support their military campaigns. The extreme caution allowed Shī'ah community to revive after the devastating blow it had endured in Karbalā. The community grew in number and later Shī'ah Imāms, especially the fifth and the sixth Imāms, ${ }^{29}$ managed to disseminate a large corpus of theological, legal and juridical teachings. These teachings later on served as one of the foundations of Shī`ah jurisprudence.

Not surprisingly, the doctrine of Taqīyyah proved to be a double-edged sword. The extraordinary possibilities embedded in it called for a balancing force against potential misuse. The central question was the "proper" application of Taqīyyah, or what may be called "principled Taqīyyah." In Shī'ah theology, there are several provisions regarding the religiously sanctioned practice of Taqiyyah. The most important balancer against the forces of expediency released by the doctrine of Taqiyyah, however, has been the example of the Shī'ah patriarch, 'Alī. He is generally praised by Shī'ah Muslims as a "man of principle," a saint who refused to "compromise his values" for the sake of expediency and practical calculations. Additional discussion on 'Alī's legacy of "principled action" and its resulting paradigm in Sh``‘ah Islam can be found in Chapter IV. Following Chapter V on Wilāyah and Walāyah, Chapter VI offers the concluding remarks for this dissertation by putting together the doctrines of Shahādah and Taqīyyah within the central Shī‘ah ontology of Wilāyah and Walāyah.

exceptions. Arguably the most important exception to this generalization is the seventh Imām, Mūsā ibn Ja'far, also known by his epithet al-Kāzim (744 - 799 C.E.), who was more politically active and, as a result, spent many years in the prison of the Abbasid caliph.

${ }^{29}$ These are Muhammad ibn 'Alī, also known by his epithet al-Bāqir (677 - 732 C.E.) and Ja'far ibn Muḥammad, also known by his epithet al-Ṣādiq (702 - 765 C.E.). 


\section{Theoretical Framework and Methodology}

Following the above overview of the structure of this dissertation, I will briefly identify the theoretical framework of this research based on the prominent schools of thought in International Relations. Theoretically speaking, this dissertation has a hybrid framework. It tries to follow a combination of "neo-traditionalist" (or "neoclassical") Realism $^{30}$ on the one hand and rule-oriented Constructivism ${ }^{31}$ on the other. The two-sided framework allows me to take into account both the role of ideas and the forces of realities; for it appears to be problematic to give prominence to one at the expense of the other -at least when it comes to Sh``‘ah history. Whether ideas are more influential in shaping the reality or vice versa may depend on the specific time and place the two collide. Nevertheless, a combination of Neoclassical Realism and Constructivism seems to provide the flexibility needed to understand the complexities abundant in Shī'ah political theology. The combination accommodates how the social reality of being a minority was translated into certain ideas and doctrines in Shī'ah Islam -e.g. the original elaboration of the doctrine of Shahādah or the proactive response in the doctrine of Taqīyyah. It also explains how certain ideas and doctrines in Shī‘ah Islam have changed the social reality -e.g. the impacts of the notion of prudence at the heart of the doctrine of

\footnotetext{
${ }^{30}$ For more information on "neo-traditionalist" or "neoclassical" Realism, see Lobell, S. E., Ripsman, N. M., \& Taliaferro, J. W. (Eds.). (2009). Neoclassical Realism, the State, and Foreign Policy. Cambridge: Cambridge University Press; Cozette, Murielle. (2008). What Lies Ahead: Classical Realism on the Future of International Relations. International Studies Review, 10, 667-679; Rose, Gideon. (1998). Neoclassical Realism and Theories of Foreign Policy. World Politics, 51(1), 144-172; and Vasquez, John A. (1998). The Power of Power Politics: From Classical Realism to Neotraditionalism. Cambridge: Cambridge University Press.

${ }^{31}$ See Onuf, Nicholas. (1989). World of Our Making: Rules and Rule in Social Theory and International Relations. Columbia: University of South Carolina Press. See also Sterling-Folker, Jennifer. (Spring 2002). Realism and the Constructivist Challenge: Rejecting, Reconstructing, or Rereading. International Studies Review, 4(1), 73-97.
} 
Taqīyyah or, in modern times, the consequential revival of and revisions in the doctrine of Shahādah. As such, Neoclassical Realism/Constructivism seems to be an effective theoretical framework to understand the swirl of ideas and reality in Shī'ah history as well as the inevitable complexities and, at times, contradictions.

Neoclassical Realism may be considered as the return of Classical Realism following the relative decline of reductionist Neorealism in International Relations. Neoclassical Realism revives the emphasis on a more reflective mode of research in which human nature, history, and their interactions are taken seriously. Such an Augustinian-Niebuhrian sensitivity makes it possible to appreciate the complexities surrounding human existence and human conditions. ${ }^{32}$ For its ability to accommodate complexities, Classical Realism is potentially capable of conducting "Phenomenological studies" ${ }^{\$ 3}$ of religions and religious beliefs in international relations. Conducting such a task seems to be more difficult within the rationalistic framework of Neorealism or that of Liberalism. Many examples, including Morgenthau's reference to certain religious aspects of international relations and the notion of "tragedy," indicate Classical Realism's dormant capacities in this regard. ${ }^{34}$ In addition to its reflective mode of research, the study of ethics and the engagement of normative questions in Classical Realism ${ }^{35}$ provide

\footnotetext{
${ }^{32}$ See Niebuhr, Reinhold. (1932). Moral Man and Immoral Society: A Study in Ethics and Politics. New York: Charles Scribner's.

${ }^{33}$ See the following Chapter for more discussion.

${ }^{34}$ See, for instance, Morgenthau's trilogy of human nature including the "biological," "rational," and "spiritual" aspects, as well as his pessimism regarding the potential of rationality and the promises of modernity [see Morgenthau, Hans J. (1946). Scientific Man vs Power Politics. Chicago: University of Chicago Press].

${ }^{35}$ See, for instance, Carr, E. H. (2001). The Twenty Years' Crisis 1919-1939: An Introduction to the Study of International Relations. New York: Palgrave Macmillan.
} 
the necessary, albeit primitive, foundation for the study of religion in international relations. The question of norms relates to the second element of my theoretical framework, namely norm-oriented Constructivism. ${ }^{36}$

Despite important potential of Classical Realism in terms of understanding normative questions, this school of thought has yet to offer a systematic framework for addressing such questions. The challenge of addressing normative questions is where the contributions of Constructivism in general and rule-oriented Constructivism in particular are significant. Except for Neorealism, there is arguably no other school of thought in International Relations that offers a solid "theoretical system" as rule-oriented Constructivism does. ${ }^{37}$ The Constructivist theoretical system is based on a well-thoughtout set of concepts and a clear pattern of interaction among those concepts. When it comes to the study of religion in International Relations, therefore, I share with Kubálková that rule-oriented Constructivism is more capable of understanding religion compared to other Constructivist or non-Constructivist schools of thought. ${ }^{38}$ As explained

\footnotetext{
${ }^{36}$ I use norm-oriented Constructivism and rule-oriented Constructivism interchangeably. In an analytically insightful review of Constructivism, Burch differentiates between the two and names the works of scholars such as Ruggie and Finnemore as examples of norm-oriented Constructivists and those of theorists such as Onuf and Kratochwill as examples of rule-oriented Constructivists. One perceivable difference is the notion of identity, which Onuf is reluctant to use. Though insightful, however, the distinction does not seem to be decisive. Within rule-oriented Constructivism, norms can still be accommodated as less formal rules. In addition, resorting to the notion of identity is not always necessary to explain the effects of norms/rules on social agents as Onuf's notion of "rule/Rule" seems to deliver a similar function. In any case, I borrow from both rule-oriented and norm-oriented versions of Constructivism in my research. See Burch, Kurt. (2002). Toward a Constructivist Comparative Politics. In Daniel Green (Ed.), Constructivism and Comparative Politics (pp. 60-87). New York: M. E. Sharpe; Ruggie, John G. (1998). Constructing the World Polity: Essays on International Institutionalization. New York: Routledge; Finnemore, Martha. (1996). National Interests in International Society. New York: Cornell University Press; Onuf, Nicholas. World of Our Making: Rules and Rule in Social Theory and International Relations; and Kratochwil, Friedrich V. (1989). Rules, Norms, and Decisions: On the Conditions of Practical and Legal Reasoning in International Relations and Domestic Affairs. New York: Cambridge University Press.

${ }^{37}$ See in particular Onuf, Nicholas. World of Our Making: Rules and Rule in Social Theory and International Relations.

${ }^{38}$ See Kubálková, Vendulka. (2003). Toward an International Political Theology. In F. Petito \& P. Hatzopoulos (Eds.), Religion in International Relations: The Return from Exile (pp. 79-105). New York: Palgrave Macmillan.
} 
before, it is also the closest theoretical framework in International Relations to the Phenomenological approach I am pursuing in my research. I will not use Neorealism and Liberalism due to their inherent positivism and behavioralism, which render them less capable of understanding religious phenomena. I also will not use Wendt's Structural Constructivism due to the disabling ambiguity of the notion of "structure" at the heart of his theory. ${ }^{39}$ It is not, in other words, clear to me how one can devise a research question using Wendt's rather nebulous notion of structure.

Since the topic of my research is the evolution of the notion of security in Shī'ah history and Shī'ah theology, I use historical analysis of the overall changes in material conditions of Shī'ah Muslims in parallel to discourse analysis of their theological works. Historical analysis is the favorite method of Classical/Neoclassical Realism while discourse analysis is more at home with Constructivism. Indeed, theological discourses both reflect and affect material conditions. Therefore, the two methods are in constant dialogue here and are not dealt with separately. I will use discourse analysis to review the relevant concepts in selected texts ${ }^{40}$ of Shī'ah Islam -including the primary sources such as the Qur'ān and the Hadīth collections, as well as the secondary sources such as exegesis on the Qur'ān and jurisprudential treatises by prominent Shī'ah Fuqahā (i.e. jurists). The historical analysis will be used to better understand the relevant practices in the history of Shī'ah Islam.

\footnotetext{
${ }^{39}$ See Wendt, Alexander. (1999). Social Theory of International Politics. New York: Cambridge University Press.

${ }^{40}$ See the list of Classical Sources in the Bibliography.
} 
In terms of specific texts used in this research, the works of some prominent Shī‘ah Fuqahā have been of particular importance. ${ }^{41}$ These figures include -but are not limited to- Muḥammad ibn Bābawayh (Shaykh al-Ṣadūq), al-Sharīf al-Raḍī, Shaykh alMufīd, al-Sharīf al-Murtaḍā, Shaykh al-Ṭūsī, Amīn al-Islām Ṭabarsī, Aḥmad ibn Idrīs alḤillī, Muḥaqqiq Ḥillī, 'Allāmih Ḥillī, Muḥammad ibn Makkī (Shahīd al-Awwal), Muhaqqiq al-Karakī, Shahīd al-Thān̄i, Muḥaqqiq al-Ardabīlī, Mullā Muḥsin Fiỵ̣ Kāshānī, al-Ḥurr al- 'Āmilī, ‘Allāmih Majlisī, Fāḍil Hindī, Ja'afar Kāshif al-Ghițā’, Mullā Aḥmad Narāqī, Shaykh al-Anșārī, and Șāḥib al-Jawāhir.

From a certain perspective, the present dissertation is a humble addition to the late Professor Hamid Enayat's Modern Islamic Political Thought. While Professor Enayat addressed some central questions in Political Theory of Shī'ah and Sunnī Islam, I hope to contribute to our knowledge of Shī'ah Islam by addressing some related questions in the field of Strategic Studies. Indeed Enayat briefly addresses notions such as Shahādah and Taqīyyah in his important work. He does so, however, within the framework of political theory and political ideas. Given its relevance and importance, his foundational work has been reviewed and discussed in Chapters II, III, IV and $\mathrm{V}^{42}$ On the basis of his initial thoughts and contributions, I will try to shed some more lights on the strategic consequences of these political doctrines, their historical and theological backgrounds, and their essential and strategic connection to the notions of Wilāyah and Walāyah.

\footnotetext{
${ }^{41}$ I am indebted to Professor Mohsen Kadivar for his help in identifying the key figures among classical Shi' ${ }^{\prime}$ ah jurists and theologians in regard to the subject of this dissertation [M. Kadivar, personal communication, September 22, 2010].

${ }^{42}$ I am indebted to Professor Farhang Rajaee who first directed me to Hamid Enayat's important contribution. Through a number of conversations regarding this dissertation in 2011, Professor Rajaee helped me to better understand the essential relationship between the present research in the field of Strategic Studies and Professor Enayat's foundational work in the field of Political Theory.
} 


\section{CHAPTER II}

\section{A REVIEW OF THE LITERATURE}

\section{Introduction}

Given the multidisciplinary nature of the research question in my dissertation, different bodies of literature have been examined. In particular, I review the literature on religion produced by the International Relations discipline as the literature for which my research is a case study. I then explore parts of the Security Studies literature within International Relations to further contextualize my study. In fact the notion of strategic cultures comes from this subset of International Relations literature and the study of strategic culture in Shī'ah Islam lies within an emerging strategic culture literature. The main interlocutors of my research are, therefore, those scholars in the field of strategic culture studies in International Relations discipline. In a larger context, however, my study belongs to Political Science literature and not that of Religious Studies, although some of the relevant Religious Studies literature on Shī'ah Islam must be engaged. The related Religious Studies literature, however, have been used within the theoretical frameworks of International Relations. In fact, one of the contributions of this dissertation is to convey and represent some of the Religious Studies literature on Shī'ah Islam to scholars of International Relations in an accessible fashion.

It is also important to emphasize that my dissertation is strictly narrowed to the study of the majority Twelver Shī'ah Islam and not other versions of Shī'ah Islam such as

the Ismā'îlīs or Zaydīs. In other words, whenever the term Shī'ah is used in this dissertation, it refers to Twelver Shī'ah unless otherwise specified. Some of the general results of my study, however, may be cautiously extended to other branches of Shī'ah 
Islam. In addition, in order to better understand specificity of the Twelver Shī ${ }^{-} \overline{1}$ doctrines and practices, references may be made to relevant arguments in other -Sunnī or Shī' ${ }^{`}$ ahbranches of Islam whenever necessary.

\section{International Relations: Religion and Secularism}

There is a challenge associated with any study of religion conducted within the framework of the modern Social Sciences. The challenge arises from the fact that these sciences are generally secular in their paradigms. As one of the products of the Enlightenment, the modern Social Sciences followed the powerful convictions of that age about the fate of religions. The influential thinkers of the Enlightenment understood Christianity and, by extension, other religions of the world as fading phenomena belonging to the past. Religions were, at worst, collections of pre-modern man's distorted view of the world he lived in or, at best, a necessary stage of man's "progress" towards modernity. As a result, the rise of the Enlightenment had rendered this pre-modern stage an obsolete one. The modernist faith arguably relied on two assumptions about the function of religions and on the two associated developments in Europe. The first projected function of religions was to provide men with explanation of the world. With the emergence of the European scientific revolution in the centuries that preceded the Enlightenment and with the success of the experimental modern sciences in explaining the world, it was only reasonable for the Enlightenment philosophers to question the ability of religions in explaining how the world worked. ${ }^{43}$ The second presumed function

\footnotetext{
${ }^{43}$ For more philosophical discussions of faith-reason interaction in the contemporary world, see Habermas, Jürgen. (2002). Religion and Rationality: Essays on Reason, God and Modernity. Cambridge: The MIT Press; and Habermas, Jürgen, et al. (2010). An Awareness of What is Missing: Faith and Reason in a Postsecular Age. Cambridge: Polity Press.
} 
of religion was to serve as a foundation for individual and collective identities. With the Church in disarray after the Reformation and the rise of powerful nationalism and the modern nation-states, this function was also fulfilled by other non-religious entities. Nationality began to supersede religious ties in defining men's allegiances. These two developments, i.e. scientific revolution and the rise of the modern nation-states, led to the relative demise of Christianity in Europe. Yet, despite the prediction of the "progressive" Enlightenment thinkers, the rest of the world did not follow the suit. Not only have religions not disappeared from our social scenery, some of the major events of the second half of the twentieth century can only be understood as a comeback of religions to the fore. As a result, many scholars of modern Social Sciences have begun to reconsider some tenets of the prevailing secular worldview. Despite the scholarly efforts to accommodate the revival of religions, the academic Social Sciences are not yet a fully open environment for studying religious phenomena. Study of religions is even more challenging when it comes to International Relations, arguably the most secular of all Social Sciences. As mentioned above, the relative demise of Christianity and the disappearance of God as a point of reference in Europe from the sixteenth century onward has been one of the permissible causes of the rise of the modern nation-states. In fact, some scholars of International Relations consider the modern nation-states as modern secular gods and nationalism as a modern secular religion. ${ }^{44}$ Therefore, International Relations emerged as a secular discipline by default due to the secular nature of the object of its study. The historical trajectory, in turn, renders studies on religion in International Relations particularly challenging.

\footnotetext{
${ }^{44}$ M. Mesbahi, Interviews, Spring 2009.
} 
Despite all the difficulties, there appeared a surge in a new type of literature on religion in International Relations after the end of the Cold War. As Berger argues, this emerging literature questioned "[t]he [validity of the] proposition that modernity necessarily leads to a decline of religion." 45 As a result, many International Relations scholars involved themselves in the discussion of religion while not quite comfortable in doing so. Wallerstein's analysis is a sample outcome of such a situation. While acknowledging the gap in the scholarship and the necessity of inclusion of religion, he appears to maneuver around the difficult how questions. ${ }^{46}$ The wary accommodation of religious phenomena in International Relations might be an indication of still-deep attachments to secularized paradigms. In fact, Berger claims that there are two exceptions to the "desecularization" of the world today. One is Western Europe and the other is students with "Western-type higher education [...] in the humanities and social sciences." 47

The now undisputed argument about the necessity to take religions into account does not provide us with much insight anymore. The more difficult question is how to take religions into account. Here, most of the literature in International Relations seems to be ambiguous in its approaches. An example of this ambiguity may be found in the analysis put forward by Fox and Sandler. ${ }^{48}$ The authors argue for the necessity of adding

\footnotetext{
${ }^{45}$ Berger, Peter. (2000). Secularism in Retreat. In J. L. Esposito \& A. Tamimi (Eds.), Islam and Secularism in the Middle East (pp. 38-51). New York: New York University Press. p. 39.

${ }^{46}$ Wallerstein, Immanuel. (2005). Render Unto Caesar?: The Dilemmas of a Multicultural World. Sociology of Religion, 66(2), 121-133.

${ }^{47}$ Berger, Peter. Secularism in Retreat. p. 45.

${ }^{48}$ Fox, Jonathan, \& Sandler, Shmuel. (2004). Bringing Religion into International Relations. New York:
} 
religion to Realism for religion has an important legitimizing function for governments and for their policies. Furthermore, religion plays a significant role in local conflicts, and in contrast to the Enlightenment presumptions, it is still a fundamental source of "identity." Yet, the lack of a clear vision on how to include religion in the study of international relations seems to have led to the authors' acknowledgment of the methodological and epistemological deficiencies. They conclude that their book "leaves us with as many questions as answers" ${ }^{49}$ in regards to the study of religion. Fox and Sandler's conclusion is in no way uncommon as many of the works on religion in International Relations indicate similar methodological and epistemological uncertainties.

A part of the problem in secular studies of religion arises from traditional secular convictions. Hurd, for instance, claims that, "[t]o seal its claim to moral superiority, secularism denominates 'religion' as the domain of the violent, the irrational, the undemocratic, [and] the 'other'." ${ }^{50}$ Hurd also provides a brief historiography of the concept of the "secular" in the West and argues that secularism is intertwined with the notion of "taking possession." According to Hurd, "in the Westphalian era, the term "to secularize' referred specifically to the laicization of church lands.. ${ }^{, 51}$ As such, secularism has had, from its origin, certain totalitarian potential and tendencies. In a similar vein, Esposito examines some cases of historical ties between secularism on the one hand and

Palgrave Macmillan.

${ }^{49}$ Ibid. p. 179.

${ }^{50}$ Hurd, Elizabeth S. (2004). The Political Authority of Secularism in International Relations. European Journal of International Relations, 10(2), 235-262. p. 237.

${ }^{51}$ Ibid. p. 241. 
suppression and dictatorship on the other. ${ }^{52}$ Built upon her assessment of secularism and its "aggressive" nature, Hurd questions the secularist hegemony in International Relations. $^{53}$

At the same time, one must not ignore or underrate certain secularist innovations to accommodate study of religious phenomena within the secular framework of the modern Social Sciences. Casanova, for instance, offers a nuanced understanding of the challenges secularization is facing in the West. ${ }^{54} \mathrm{He}$ aims to understand and accommodate the role of religion in the public sphere within the framework of modern secularization project. To do this, secularization itself must be revisited, Casanova argues. He differentiates between three elements of the concept. The first element is the Enlightenment premise that religious beliefs and practices are declining as a result of lack of validity and thus relevance. The second element of secularization is what one may call the French perspective, or laïcité, which emphasizes the public-private dichotomy. Laïcité then brushes religion and religious practices to the latter sphere. The last is the AngloSaxon approach that revolves around the separation of political authority, i.e. the state, on the one hand and the religious authority, i.e. the church, on the other. According to

\footnotetext{
${ }^{52}$ See Esposito, John L. (2000). Islam and Secularism in the Twenty-First Century. In John L. Esposito \& Azzam Tamimi (Eds.), Islam and Secularism in the Middle East (pp. 1-12). New York: New York University Press.

${ }^{53}$ See also Hurd, Elizabeth S. (2008). The Politics of Secularism in International Relations. Princeton: Princeton University Press; as well as her article in Shah, T. S., Stepan, A., \& Toft, M. D. (Eds.). (2012). Rethinking Religion and World Affairs. Oxford: Oxford University Press. The edited volume offers several other insightful treatments of religion in international relations as well. See also Snyder, Jack L. (Ed.). (2011). Religion and International Relations Theory. New York: Columbia University Press, which offers a collection of articles on how the rising visibility of world religions is affecting the foundations of global politics including the institution and functions of state as well as the notions of war and territory

${ }^{54}$ Casanova, José. (1994). Public Religions in the Modern World. Chicago: University of Chicago Press.
} 
Casanova, the first element has been falsified in many parts of the world -though it is arguably still valid in Western Europe. ${ }^{55}$ The second element, on the other hand, fails to understand religions' public roles. It is, therefore, the last element that is the central pillar of modern secularization according to Casanova. It is also this last element that offers a viable solution in secular study of religions and public religiosity. Following the AngloSaxon interpretation of secularization, one may defend the public role of religions while remaining faithful to the basic tenets of secularization. ${ }^{56}$

Geertz's approach is also an example of secularist novelty to study religion without abandoning secular premises. By defining religion as a "cultural system," Geertz is opening the possibility of Huntingtonian treatment of religion where religion is subsumed in a rather nebulous notion of civilization or culture. Geertz defines religion as “(1) a system of symbols which acts to (2) establish powerful, pervasive, and long-lasting moods and motivations in men by (3) formulating conceptions of a general order of existence and (4) clothing these conceptions with such an aura of factuality that (5) the

\footnotetext{
${ }^{55}$ In contrast, Charles Taylor believes that secularism "has to do with the (correct) response of the democratic state to diversity" and not "the relation of state and religion [see Taylor, Charles. (2012). The Meaning of Secularism. In D. R. Hoover and D. M. Johnston (Eds.), Religion and Foreign Affairs: Essential Readings (pp. 11-20). Waco: Baylor University Press. p. 12; and Taylor, Charles. (2007). A Secular Age. Harvard: Harvard University Press]. For other examples of theoretical re-conceptualization of modern secularism, see Calhoun, C., Juergensmeyer, M., \& VanAntwerpen, J. (Eds.). (2011). Rethinking Secularism. Oxford: Oxford University Press.

${ }^{56}$ See also Casanova's article in Shah et al. (Eds.). Rethinking Religion and World Affairs, as well as his response to Talal Asad in Casanova, José. (2006). Secularization Revisited: A Reply to Talal Asad. In D. Scott \& C. Hirschkind (Eds.), Powers of the Secular Modern: Talal Asad and His Interlocutors (pp. 12-30). Stanford: Stanford University Press. Talal Asad's works may be viewed as an Edward Saidean treatment of secularism and secularization in their critical undertone. See, for instance, Asad, Talal. (2003). Formations of the Secular: Christianity, Islam, Modernity. Stanford: Stanford University Press.
} 
moods and motivations seem uniquely realistic." 57 (emphasis in the original)

The definition is cautiously articulated so that it allows Geertz to "take religions seriously" while remaining within the boundaries of secularism. In particular, the notion of religious symbols being "clothed" in "an aura of factuality," which seems to be the implicit consensus in the secular academia, is pronounced here following the reference to the "long-lasting" power of such symbols.

Given the above general context, the diverse jargon of the emerging literature on the subject of religion in International Relations may be organized within four conceivable frameworks. These, in the order of divergence from the basic premises of modernism, include the Enlightenment, Identity, Phenomenological and Traditionalist approaches.

The first possible analytical framework is the classic modern stance. The Enlightenment approach asserts that religions are to fade away -at least from the public sphere. As such, religions gradually become of lesser significance in social analyses. It is an Auguste Comte approach in which it is assumed that humanity is "growing out of religion." The Enlightenment approach seems to have been the mainstream perspective towards the study of religion in International Relations until recently when the events of the last couple of decades forced many scholars of International Relations and Political Sciences to search for alternative analytical frameworks. ${ }^{58}$ The search has led to the

\footnotetext{
${ }^{57}$ Geertz, Clifford. (1973). The Interpretations of Cultures. New York, Basic Books. p. 90.

58 The dismissal of religions by variety of Marxian and Marxist theories as "false consciousness" may be viewed essentially within the framework of the Enlightenment approach, though later generations of Marxian theories also began to accommodate religions at least as one of the social forces to be reckoned
} 
emergence of a literature in International Relations that follows the Identity approach and -to a lesser extent- the Phenomenological approach.

The second analytical framework is the Identity approach in which religion is acknowledged as a subjective force with certain objective manifestation such as rituals. This subjective force partially shapes the identity and thus behavior of social actors interacting with it. The Identity approach is arguably close to Durkheim's sociology of religion in which religion is a socially constructed reality serving to orient individuals and societies. ${ }^{59}$ In the Identity approach, religion is often seen as a phenomenon similar to ethnicity. Religion could be used, for instance, as an instrument at the disposal of political actors to legitimize their actions or to mobilize the masses. By avoiding deep engagement of religions, the Identity approach dodges some difficult questions. In particular, it overlooks the theoretical challenge that the rise of religions has posed to the discipline of International Relations. In International Relations, therefore, the Identity approach towards religion remains essentially "functionalist," i.e. sensitive to political functions of religion in international politics. Religions are seen as one of the compartments of the "identity structure" and as such, they can be measured and analyzed by associated and manifested behaviors. Arguably one of the most influential pieces on International Relations and religion, The Clash of Civilizations, follows this approach. ${ }^{60}$ Huntington

with. See Raines John. (Ed.). (2002). Marx on Religion. Philadelphia: Temple University Press; and Mendieta, Eduardo. (Ed.). (2005). The Frankfurt School on Religion: Key Writings by the Major Thinkers. New York: Routledge.

${ }^{59}$ See Durkheim, Émile. (2001). The Elementary Forms of Religious Life. Oxford: Oxford University Press.

${ }^{60}$ See Huntington, Samuel P. (1996). The Clash of Civilizations and the Remaking of World Order. New York: Simon \& Schuster. 
borrows the term from the prominent "Orientalist," Bernard Lewis. ${ }^{61}$ Lewis employs civilizational conceptualization $^{62}$ to understand the Muslim world. In fact, The Clash of Civilization may be seen as an example of the "Orientalist" literature ${ }^{63}$ in International Relations. More nuanced versions of the Identity approach can be found in the literature in which religions are seen as the foundation of normative power for certain actors. In Shi 'a Revival, for instance, Vali Nasr takes such an instrumentalist approach towards religion. ${ }^{64}$ Within the Identity approach, it is a frequent solution to view religion as an ideology, so that religion can be treated in the same way that nationalism has been analyzed. The appeal of the Identity approach is that the reduction of religion to ideology obviates the necessity of difficult theoretical and methodological innovations. The same concepts and methods that have been employed in understanding ideologies, or ethnicity, can now be applied to a new "case," namely religion. The Identity approach seems also to be the favorite approach for scholars who tend to think within the (neo)Realist frame of thought in International Relations. For this group of scholars, accommodation of non-

\footnotetext{
${ }^{61}$ See Lewis, Bernard. (1990). The Roots of Muslim Rage. The Atlantic Monthly, 266(3), 47-58.

${ }^{62}$ By civilizational conceptualization, I mean using the broad notion of civilization to explain social phenomena at large. Civilizational conceptualizations, in general, seem to fit comfortably within the Identity approach. For further discussion, see Hall, M., and Jackson, P. T. (Eds.). (2007). Civilizational Identity: The Production and Reproduction of "Civilizations" in International Relations. New York: Palgrave Macmillan.

${ }^{63}$ The term "Orientalism" refers here to the mainstream school of thought in the study of the Orient. It also invokes the important critique of Oriental Studies by Edward Said. Huntington and Lewis both believe that modern secular democracies are a project deeply rooted in the Western civilizational heritage -and in the case of Huntington, more specifically in the Protestant Christian heritage. They, therefore, cast doubts on the possibility of successful secularization of other cultures or civilizations leading to their conclusion of inevitable forthcoming clash of civilizations. See Said, Edward. (1978). Orientalism. New York: Vintage Books; Huntington, Samuel P. The Clash of Civilizations and the Remaking of World Order; and Lewis, Bernard. The Roots of Muslim Rage.
}

${ }^{64}$ See Nasr, Vali. (2006). Shi ' a Revival: How Conflicts within Islam Will Shape the Future. New York: WW Norton \& Co. 
material forces is not always unproblematic. Furthermore, the Identity approach is compatible with the Constructivism of the type Wendt advocated; ${ }^{65}$ for this version of Constructivism engages the concept of identity and that of culture.

In addition to Wendt's Constructivism, scholars writing within the Identity approach sometimes engage Classical Realism as a potentially capable theoretical perspective to understand religion in international relations. Writing in the aftermath of September 11 terrorist attacks, Keohane begins with the argument that "[w]e need to synthesize insights from classical realism, institutionalism, and Constructivism, but we also need to take alternative worldviews —including religious ones — more seriously.",66 His analysis shows the angle via which an Identity approach tackles the question of religion. Keohane justifies the use of Classical Realism in studying religious worldviews because, according to him, Classical Realism "takes very seriously the human desires to dominate or to hate., ${ }^{, 67}$

Thomas explores religion and international conflict by viewing religion as, inter alia, "a form of ideology," "a form of identity," "a form of "soft power'," and as -rather ambiguous notions of- "civilization or culture area."68 One may argue that the broad and uncertain analytical framework behind these many descriptions characterizes the Identity

\footnotetext{
${ }^{65}$ See Wendt, Alexander. Social Theory of International Politics.

${ }^{66}$ Keohane, Robert O. (2002). Power and Governance in a Partially Globalized World. New York: Routledge. p. 283.

${ }^{67}$ Ibid. p. 272.

${ }^{68}$ See Thomas, Scott M. (2000). Religion and International Conflict. In K. R. Dark (Ed.), Religion and International Relations (pp. 1-23). New York: Palgrave Macmillan. pp. 1-11.
} 
approach. The next step is to discuss "[ $[$ ] he religious challenge to international society" caused by the confrontation of "strong religions" versus "weak states." Hence, Thomas's analysis may be considered as a mainstream example of the Identity literature on religion in International Relations. ${ }^{70}$ Once again, the author calls for "taking religion seriously" and declares that the twentieth century was "the last modern century." "71 This is in line with Gellner's implicit dismissal of "non-fundamentalist" religiosities as inconsequential while making a scathing attack against "nihilist" postmodernism. ${ }^{72}$ Gellner paints a world in which three forces of "religious fundamentalism," "rationalist fundamentalism," and "relativist postmodernism" compete with each other. His analysis of Muslim "fundamentalism" offers some fresh, albeit debatable, insights. Yet, it is the convenient comparison of categorically disparate phenomena such as religions and "scientific methods" ${ }^{\text {"73 }}$ that appears problematic in Gellner's work. In his argument against the "end of modernity," Thomas also follows such clear-cut categorizations and convenient comparisons. Thomas claims that the weakening of modern sociopolitical structures is caused by a deepening identity dilemma;

"Ernest Gellner has argued that since the period of colonial occupation the developing countries have been confronted with a

\footnotetext{
${ }^{69}$ Ibid. p. 14.

${ }^{70}$ See also Haynes, Jeffrey. (1998). Religion in Global Politics. New York: Longman; and Haynes, Jeffrey. (2011). Religion, Politics, and International Relations: Selected Essays. New York: Routledge.

${ }^{71}$ Thomas, Scott M. (2000). Taking Religious and Cultural Pluralism Seriously: The Global Resurgence of Religion and the Transformation of International Society. Millennium, 29(3), 815-841. p. 816.

${ }^{72}$ See Gellner, Ernest. (1992). Postmodernism, Reason, and Religion. London: Routledge. pp. 4-6; and Ibid. p. 50

${ }^{73}$ Ibid. p. 80.
} 
dilemma: should they emulate the West and spurn their own culture in order to gain equality in power, or should they affirm their own cultural and religious traditions but remain materially weak?"74

In line with Asad's criticism of Geertz's notion of "religion as a cultural system,,"75 Thomas believes that in response to the above identity dilemma, religiosity has changed in certain parts of the world. For instance, a new -privatized- religion has been "invented" in order to serve modern nation-states through shaping "the identity of the community. ${ }^{, 76}$ It must be mentioned, however, that along with his mainly identity-based argument, Thomas examines the ethical cores of major religious traditions in the world as well. These ethical cores, according to Thomas's phenomenological observation, have noticeable potential for shaping international relations. The phenomenological analysis leads Thomas to write about religions' potential roles in promoting peace or fighting poverty.

A similar oscillation between the Identity approach and the Phenomenological approach ${ }^{77}$ can be found in Thomas's other works. ${ }^{78}$ The author recognizes the crisis of modernity and the role played by the quest for "authenticity" in response to that crisis.

\footnotetext{
${ }^{74}$ Thomas, Scott M. Taking Religious and Cultural Pluralism Seriously. p. 817.

75 See Geertz, Clifford. The Interpretations of Cultures; and Asad, Talal. (1983). Anthropological Conceptions of Religion: Reflections on Geertz. Man (NS), 18(2), 237-259.

${ }^{76}$ Thomas, Scott M. Taking Religious and Cultural Pluralism Seriously. p. 823.

${ }^{77}$ See below for more extensive discussion of the Phenomenological approach in the study of religion in International Relations.

${ }^{78}$ See, for instance, Thomas, Scott M. (2005). The Global Resurgence of Religion and the Transformation of International Relations: The Struggle for the Soul of the Twenty-First Century. New York: Palgrave Macmillan.
} 
Thomas views this quest as one of the forces behind the worldwide rise of religions. To the extent that Thomas's analysis strives to "rethink" the interaction of religion on the one hand and international cooperation, diplomacy, international conflicts, development, and democracy on the other, the work tilts towards the Phenomenological approach. The content of this rethinking, however, is not far from the Identity approach; for the emerging turn towards faith, Thomas argues, is the result of the "search for authentic identity, meaning and economic development." ${ }^{, 79}$ The significance of religions in international relations, therefore, remains tied to the provision of transnational identity and soft power.

A number of scholars writing within the Identity approach have focused on the study "fundamentalism" instead of religions. One prime example of this is the Chicago Fundamentalism Project. Defined as an attempt by "true believers [...] to arrest the erosion of religious identity," fundamentalism is understood by Almond and Appleby as a response to securitization of religion. ${ }^{80}$ Reporting the findings of the Chicago Project, Almond and Appleby review a variety of arguably disparate phenomena under the same rubric of fundamentalism. The authors acknowledge the limitations of using the term "fundamentalism." Yet, they go on to explain the increasing visibility of different religions by resorting to the notion of "enclave culture." The conceptual reduction allows Almond and Appleby to associate various, otherwise dissimilar, challenges together. Moreover, by building their analysis of religions in international relations around the

\footnotetext{
${ }^{79}$ Ibid. p. 43.

${ }^{80}$ See Almond, G. A., Appleby, S., \& Sivan, E. (2003). Strong Religion: The Rise of Fundamentalisms Around the World. Chicago: University of Chicago Press.
} 
notion of "enclave cultures," Almond and Appleby formulate the problématique of religion for International Relations as an enclave one. They seem to take for granted secularization as the status quo order of the world "attacked by strong religions."

Antoun also uses the term fundamentalism to identify an "orientation" that fights against the "ideology of modernism." 81 Here, fundamentalism appears as an identity bastion. Antoun analyzes his anthropological observations in Jordan to pinpoint what he believes are the essential characters of fundamentalism, namely traditioning, totalism, activism, scripturalism, search for purity, selective modernization, controlled acculturation, and perception of history as good-evil struggle. Similar to the cultural/civilizational approach of Huntington, however, the definition appears to be nebulous and the conceptual boundaries of the notion of fundamentalism remain underdefined in some of these characteristics.

As noted above, some scholars of the Identity approach tend to ideologize religions. Juergensmeyer, for instance, argues that the world is experiencing a rise of ethnic "religious nationalism" against secular states. This is partly a result of the crisis and failure of secular versions of nationalism in fulfilling ethno-national demands. ${ }^{82}$ "Religious nationalism" in turn leads to a "new Cold War" according to him. ${ }^{83}$ This type of nationalism is the "ideology [that] combines traditional religious beliefs in divine law

\footnotetext{
81 See Antoun, Richard T. (2001). Understanding Fundamentalism: Christian, Islamic, and Jewish Movements. Walnut Creek: AltaMira Press.

${ }^{82}$ See Juergensmeyer, Mark. (2001). The Global Rise of Religious Nationalism. In D. N. Hopkins, L. A. Lorentzen, E. Mendieta, \& D. Batstone (Eds.), Religions/Globalizations: Theories and Cases (pp. 66-83). London: Duke University Press.

${ }^{83}$ See Juergensmeyer, Mark. (1993). The New Cold War?. Berkeley: University of California Press.
} 
and religious authority with the modern notion of the nation-state. ${ }^{\prime 84}$ The turn to religion was, according to Juergensmeyer, an attempt "to build a "postcolonial" national identity" 85 at the time when the newly born countries strived for an enduring foundation for the definition of the self. On the basis of the above analysis, Juergensmeyer concludes that the problem is not a religious but a political one. The treatment of religion as primarily a competing ideology continues to shape Juergensmeyer's later works on religious violence. For instance, he employs a rather contradictory notion of "cosmic war" ${ }^{\prime 86}$ waged by terrorists and emphasizes its "theatrical power" in impressing the terrorists' audience. ${ }^{87}$ Along with his Identity approach, Juergensmeyer does sometimes engage phenomenological observations. He does so in particular to understand the mindset of those involved in acts of religious violence. These phenomenological observations also allow him to identify some of the socioeconomic contexts of such violent acts. For instance, he believes that social isolation and loss of agency are among the forces shaping the socioeconomic contexts of terrorism. ${ }^{88}$ Juergensmeyer's working compromise between the Identity approach and phenomenological observations eventually leads to his rather counterintuitive conclusion that "[ $\mathrm{t}] \mathrm{he}$ cure for religious

\footnotetext{
${ }^{84}$ Ibid. p. 69.

${ }^{85}$ Ibid. p. 74.

${ }^{86}$ The term is a problematic one given the Greek roots of the term cosmos, which means, at the same time, order and beauty.

${ }^{87}$ See Juergensmeyer, Mark. (2003). Terror in the Mind of God: The Global Rise of Religious Violence. Berkeley: University of California Press.

${ }^{88}$ For a similar approach, see also Stern, Jessica. (2003). Terror in the Name of God: Why Religious Militants Kill. New York: Harper Collins Publishers.
} 
violence may ultimately lie in a renewed appreciation for religion itself ${ }^{89}$ or, in other words, in employing religions' potential to contain their potentially harmful tendencies.

The third approach is the Phenomenological one, which studies religions with methodological "empathy." The notion of methodological empathy is related to Weber's notion of "empathy." It highlights the necessity of understanding the religious "perspectives" in order to understand religious behaviors and identities. The Phenomenological approach is also in line with the phenomenological movement in philosophy. ${ }^{91}$ One assumption of the Phenomenological approach is that, unless studied from within, religions cannot be fully understood and explained. Therefore, the Phenomenological approach takes religions seriously in their own terms but only because religions have been taken seriously in their own terms by their followers. The Phenomenological approach strives to understand, as much as possible, what it means to be a dedicated Muslim, Buddhist, Christian or Hindu. It strives to, in other words, understand the lived experience of a believer. Compared to the Identity approach, the Phenomenological approach allows a deeper appreciation of the difficulties involved in the study of religion and also a better understanding of the new possibilities and limitations emerging from the rise of religions in international affairs. That is why some of the more nuanced works on religion in international relations ${ }^{92}$ belong to the

\footnotetext{
${ }^{89}$ Juergensmeyer, Mark. Terror in the Mind of God: The Global Rise of Religious Violence. p. 243.

${ }^{90}$ See Weber, Max. (1993). The Sociology of Religion. Boston: Beacon Press.

${ }^{91}$ See, for instance, Husserl, Edmund. (1970). The Crisis of European Sciences and Transcendental Phenomenology. Evanston: Northwestern University Press; and Heidegger, Martin. (2004). The Phenomenology of Religious Life. Bloomington: Indiana University Press.

92 The list of potential meeting points of religions and international affairs as discussed in this body of
} 
Phenomenological approach. The Phenomenological approach is more akin to those scholars who write and think within the Constructivist school of thought in International Relations. In fact, Wendt's notion of "culture" as "shared knowledge affecting identity and behavior" can also be used in Phenomenological studies, albeit Wendtian Constructivism seems to be more suitable for the Identity approach discussed above. ${ }^{93}$ The Phenomenological approach seems to be more comfortable using Onuf's systematic Constructivism. ${ }^{94}$ Here, religion can be seen as a normative system or, as Onuf puts it, a system of rules. $^{95}$

Kubálková advocates the development of the subfield of International Political Theology. ${ }^{96}$ She maintains that, given the emphasis put by religions on texts and interpretations, Onuf's linguistic and rule-oriented Constructivism is the proper analytical framework for the development of International Political Theology. Besides this intriguing suggestion, however, her discussion of International Political Theology

literature includes religious modern just war theories, religions and peacemaking processes and efforts, religions and environmental protection movements, religions and anti-poverty movements, Christian Liberation Theology and its counterparts in other faith traditions, religions and just world order(s), and religions and diversity. It must be mentioned, however, that writing within the Phenomenological approach does not necessarily mean a positive assessment of religion and its social and international roles.

${ }^{93}$ Wendt, Alexander. Social Theory of International Politics.

${ }^{94}$ Onuf, Nicholas. World of Our Making.

95 The feminist treatments of religion in International Relations may also be categorized under the Phenomenological approach but with a masculinity-femininity awareness involved. An example of this feminist Phenomenological approach is the presentation given by Ann Tickner at the Robert Keohane Festschrift Conference, Princeton University, February 2005. It is within a similar Phenomenological paradigm when feminist theologians of various religious traditions call for "feminine interpretations" of religious texts, symbols, rituals, and experiences. Such "feminine interpretations" are deemed to allow one to go beyond rationalistic and "masculine understandings" of religion that, according to these advocates of feminine theology, has been prevalent in the post-Enlightenment era.

${ }^{96}$ See Kubálková, Vendulka. Toward an International Political Theology. 
remains, for the most part, on the abstract level. Viewing religion as a speech act, Kubálková uses a post-positivist secular language to define religion as a "system of rules (mainly instruction-rules) and related practices, which act to [...] explain the meaning of existence including identity, ideas about self, and one's position in the world, [...] thus motivating and guiding the behaviour of those who accept the validity of these rules on faith." ${ }^{97}$ Kubálková's definition, for its emphasis on the function of religions in defining identity and in guiding behavior, is close to the Identity approach. Yet, the abstract level of International Political Theology renders Kubálková's conceptual contribution flexible enough to be employed by those scholars who conduct phenomenological studies of religions.

Within the Phenomenological paradigm and in one of the insightful pieces written on religion in International Relations discipline, Laustsen and Wæver employ the Copenhagen School of Security Studies to analyze securitization of religion. ${ }^{98}$ Their argument begins with taking the orientation common in Identity approach literature on religion, namely with the inquiry about the link between religions on the one hand and questions of threat and security on the other. Religion is one of the "sectors" in which a securitizing agent can perform a securitizing speech act. Acknowledging the limitations of the identity-based and "functionalist" definition of language, Laustsen and Wæver argue for the necessity of defining religion in the ways it appear to the believers, i.e. a phenomenological definition. They use various notions and analyses by Kierkegaard,

\footnotetext{
${ }^{97}$ Kubálková, Vendulka. (2000). Towards an International Political Theology. Millennium - Journal of International Studies, 29, 675-704. p. 695.

${ }^{98}$ See Laustsen, Carsten B., \& Wæver, Ole. (2000). In Defence of Religion: Sacred Referent Objects for Securitization, Millennium - Journal of International Studies, 29, 705-739.
} 
Bataille, and Smart to substantiate such phenomenological definition of religion; and they argue that such definition must take into account the "doctrinal," "ritual," "mythic/narrative," "experiential/emotional," "ethical/legal," "social," and "material" dimensions of the Sacred. ${ }^{99}$ According to the authors,

"religion has three main dimensions. It has faith as the guiding principle of discourse. This faith is only possible due to a distinction between immanent and transcendent, and this distinction is finally reinterpreted as a distinction between sacred and profane. On the one hand, the transcendent is interpreted as that which is given by divine speech, purity, timelessness, supernatural powers, goodness, benevolence/forgiveness/salvation, and sublimity. [...] On the other hand, the earthly realm is interpreted as characterised by 'writing', impurity, selfishness, constraints by time and space, the ordinary, evil, egoism/revenge, and the representable/copies. All seven dimensions propose a way of overcoming this separation of the earthly and the divine. These mediating practices are scriptures, rituals, myths, miracles, ethics, care/community, and iconography."100

The above definition of religion is indeed a broad and comprehensive one. Despite the phenomenological originality put into this definition of religion, Laustsen and Wæver

99 For further reference, see Kierkegaard, Søren. (1962). Afsluttende Uvidenskabelig Efterskrift. København: Gyldendal; Bataille, George. (1989). Theory of Religion. New York: Zone Books; and Smart, Ninian. (1996). Dimensions of the Sacred: An Anatomy of the World's Beliefs. London: Fontana Press.

${ }^{100}$ Laustsen, Carsten B., \& Wæver, Ole. In Defence of Religion. p. 718. 
return to the Identity approach when exploring the security linkage between language and religions. Because of the sacredness of the Sacred, the authors argue, securitization of religion is almost automatic when a threat to a religion is perceived by the adherents to that religion. On the other hand, the language of "fundamentalism" is almost inherently a securitizing language. Finally, Laustsen and Wæver end up with a rather "reductionist" assertion that the "three main ways religion can be involved in international politics" include:

"1. A religious group is considered to be a threat to the survival of the state. 2. Faith is seen as threatened by whoever or whatever 'nonreligious' actor or process (states, technology, industrialism, modernism, etc.). 3. Faith is seen as threatened by another religious discourse or actor." ${ }^{\prime 101}$

In other words, there seems to be a disconnect between the authors' extensive effort to define religion in phenomenological terms in the first part, and the analysis of securitization of religion in the second part of their argument. The definition seems to remain almost insignificant in the analysis.

As noted above, the use of the term "fundamentalism" has not been limited to the scholars writing within the Identity approach. Karen Armstrong, for instance, uses it in reference to "embattled forms of spirituality." 102 Combined with her Phenomenological approach in studying religion, the above conceptualization of "fundamentalism" allows Armstrong to contextualize the phenomenon within the broader trend of the rise of

\footnotetext{
${ }^{101}$ Ibid. p. 720.

${ }^{102}$ See Armstrong, Karen. (2001). The Battle for God. New York : Random House.
} 
religions. It must be noted, however, that the Phenomenological approach began with the larger question of the crisis of secularization. ${ }^{103}$ Therefore, the Phenomenological approach tends to treat "fundamentalism" as only one of the extreme manifestations of a deeper and more consequential transformation happening in the social world. As a result, the Phenomenological approach sometimes views the role played by religion for believers as one of protection. Religious beliefs, religious rituals, and religious communities are assumed to function as a "Sacred Canopy"104 shielding the believers against subjective horrors of modernity -for instance nihilism and the crisis of meaning of life and that of suffering- as well as protecting them against objective pains and sufferings abundant in life. This role implies certain social dynamics and political consequences at the time when secularization appears to be in retreat. ${ }^{105}$

The methodological "empathy" towards religion among some Phenomenological scholars has also led to the emergence of a literature on the "constructive" side of the rise of religion. Gopin argues optimistically about the potential of common values among

\footnotetext{
${ }^{103}$ See Husserl, Edmund. The Crisis of European Sciences and Transcendental Phenomenology.

${ }^{104}$ See Berger, Peter. (1967). The Sacred Canopy: Elements of a Sociological Theory of Religion. New York: Anchor Books.

${ }^{105}$ See Berger, Peter (Ed.). (1999). The Desecularization of the World. Washington: Ethics and Public Policy Center. Norris and Inglehart disagree with such a conclusion and offer a serious alternative explanation. They argue that the rise of religions has been caused by a relative increase in the population of non-secular countries at the time when the population of most secular regions of the world -such as those in Western and Northern Europe- is falling rapidly. In other words, secularization is, according to the authors, a successful and irreversible process wherever it happens. In cases such as the United States where the rise of religion in the past four decades has not been due to indigenous demographic changes, the authors claim that the insecurity of a Capitalist structure has transformed vulnerability into religiosity. Meanwhile, immigration has also helped the boost of religiosity in the United States. See Norris, Pippa, \& Inglehart, Ronald. (2004). Sacred and Secular: Religion and Politics Worldwide. Cambridge: Cambridge University Press.
} 
world religions. ${ }^{106}$ These values include "empathy," "pacifism," "sanctity of life," “compassion," and "discipline."107 Such commonalities, Gopin argues, could serve as a foundation for conflict resolution and peacemaking. ${ }^{108}$ In the same vein and with a "leftist" twist, Falk argues for the potential benefits in the resurgence of religion in controlling the unleashed forces of globalization; and, by invoking the example of Gandhi, in helping to create a global ethical order, a "humane global government.",109 Unlike scholars writing within the Identity approach, those working within the Phenomenological framework have, thus, begun to question the validity of secularist dogmas in the Social Sciences. Despite this questioning, however, they rarely make a radical departure from the secular premises of the Social Sciences. In fact, Enlightenment "functionalism" can still be recognized in the Phenomenological literature. A common theme here is the call to engage religious creeds emphasizing social justice and human dignity for the betterment of the world. Religions appear as useful instruments towards achieving secular objectives. At the bottom line, both the Identity approach and the

\footnotetext{
${ }^{106}$ See Gopin, Marc. (2000). Between Eden and Armageddon: The Future of World Religions, Violence, and Peacemaking. Oxford: Oxford University Press. See also Gopin's article in Hoover et al. (Eds.). Religion and Foreign Affairs. pp. 271-80.

${ }^{107}$ Weber may also be considered to follow a similar approach when exploring the complex roles religions have played in human society; for he saw an essentially constructive association between Protestant doctrines on the one hand and the economic development in North America on the other. See Weber. Max. (2002). The Protestant Ethics and the "Spirit" of Capitalism and Other Writings. New York: Penguin Books.

${ }^{108}$ For an example of the related literature on "religious peacebuilding," see Hertog, Katrien. (2010). The Complex Reality of Religious Peacebuilding: Conceptual Contributions and Critical Analysis. Plymouth: Lexington Books.

109 See Falk, Richard A. (2001). Religion and Humane Global Governance. New York, Palgrave Macmillan; and Falk, Richard A. (2003). A Worldwide Religious Resurgence in an Era of Globalization and Apocalyptic Terrorism. In F. Petito \& P. Hatzopoulos (Eds.), Religion in International Relations: The Return from Exile (pp. 181-208). New York: Palgrave Macmillan.
} 
Phenomenological approach can become "instrumentalist," the former by seeing religion as a destabilizing instrument available to potentially anti-status-quo political actors; the latter by viewing religion as a potentially beneficial instrument at the disposal of statusquo political leaders or mainstream reformers. It must be noted that the discussion of the potential benefits of engaging religions in the Phenomenological literature has sometimes been balanced with the acknowledgment of the evidence of the dangers posed by religious revival to world security and prosperity.

Seiple and Hoover follow the Phenomenological approach in investigating the nexus of security and religion. ${ }^{110}$ The contributors to this edited volume cover, among other aspects, the potential social values of religion -especially those within the Abrahamic family- in contributing to issues such as promotion of peace or human dignity. The notion of "religious freedom" is a recurring theme in the book and it has even been tied to national, regional, and international security. Jean Elshtain goes as far to argue for "military intervention $[\ldots]$ guided by, not narrow realpolitik, nor by naïve humanitarianism, but by religiously grounded philosophy of justice as equal regard" (emphasis in the text). ${ }^{111}$ Along similar lines, Johnston and Sampson have edited a collection of articles on conflict resolution mechanisms and potential offered by world religions. ${ }^{112}$ The Phenomenological approach as presented in Johnston and Sampson's

\footnotetext{
${ }^{110}$ See Seiple, Robert A., \& Hoover, Dennis R. (Eds.). (2004). Religion and Security: The New Nexus in International Relations. Lanham: Rowman \& Littlefield. See also Seiple's article in Hoover, et al. (Eds.). Religion and Foreign Affairs. pp. 211-6.

111 Elshtain, Jean. (2004). Military Intervention and Justice as Equal Regard. In R. A. Seiple \& D. R. Hoover (Eds.), Religion and Security: The New Nexus in International Relations (pp. 115-130). Lanham: Rowman \& Littlefield. p. 116.

112 See Johnston, Douglas, \& Sampson, Cynthia. (Eds.). (1994). Religion, the Missing Dimension of Statecraft. Oxford: Oxford University Press. See also Johnston's article in Hoover et al. (Eds.). Religion
} 
volume stands in stark contrast to the Enlightenment approach. It acknowledges various historical and social roles played by religion and asserts that such roles should be welcomed in the future. Cases of contributions of religion to conflict resolution, peacemaking, and peacekeeping are presented as the evidence, according to the authors, for such an embrace. Eventually, the authors of this edited volume try to re-introduce the "religious dimension of statecraft," which implies that besides war, great powers, balance of power, diplomacy, and international law, one should add religion as the sixth pillar of the "international society.",113

Oscillating between the Identity and the Phenomenological approaches, Norris and Inglehart use statistics and argue that religiosity is correlated with the level of perceived security -or insecurity. ${ }^{114}$ Security, according to Norris and Inglehart, is defined in terms of basic human security, which means access to the essential means of survival and a minimum level of welfare. Taking refuge in religion, therefore, is a reaction to the perceived insecurity of a world that is filled with poverty, hunger, and disease. In a sense, despite their secular undertone and their consequential dismissal of the meaning-of-life crisis in the secularized world, Norris and Inglehart come close to explaining one of the key functions of religion, namely to offer a shelter from

and Foreign Affairs. pp. 263-70.

${ }^{113}$ See Bull, Hedley. (1995). The Anarchical Society: A Study of Order in World Politics. New York: Columbia University Press.

${ }^{114}$ See Norris, Pippa, \& Inglehart, Ronald. Sacred and Secular: Religion and Politics Worldwide. 
unavoidable contingencies of life. Their argument in International Relations parallels

Berger's argument in Sociology of Religion. ${ }^{115}$

The last approach comes from Traditionalism, or Perennialism, in Religious

Studies. Traditionalism has by and large been marginalized in Social Sciences literature.

The prominent Traditionalists such as René Guénon, Frithjof Schuon, Ananda Coomaraswamy, Seyyed Hossein Nasr, Titus Burckhardt, Martin Lings and Huston Smith are unique in modern academia for they take religions seriously on their own terms. ${ }^{116}$ Furthermore, they treat religions or, as they often called them, religious Traditions not only as a subjective force shaping actors' identity and behaviors, but also -and more importantly according to these authors- as an objective reality. In other words, Traditionalists stand in sharp contrast to the cardinal premises of the secularized modern Social Sciences and indeed modernity itself. For the most part of history, according to Traditionalists, humankind believed in the existence of parallel unseen universes along

${ }^{115}$ See Berger, Peter. The Sacred Canopy. See also Berger's article in Hoover et al. (Eds.). Religion and Foreign Affairs. pp. 21-32.

${ }^{116}$ Some of the most influential and essential works produced within the Traditionalist School of Thought include Guénon, René. (1989). Oriental Metaphysics. Unknown: Hanuman Books; Guénon, R. (1995). Fundamental Symbols: The Universal Language of Sacred Science. Cambridge: Fons Vitae; Guénon, R. (2001). The Crisis of Modern World. Hillsdale: Sophia Perennis; Guénon, R. (2004). The Multiple States of Being. Hillsdale: Sophia Perennis; Guénon, R. (2004). The Reign of Quantity and the Signs of the Times. Hillsdale: Sophia Perennis; Schuon, Frithjof. (1982). Esoterism As Principle and As Way. Hillsdale: Sophia Perennis; Schuon, F. (1984). The Transcendent Unity of Religions. Wheaton: Quest Books; Schuon, F. (2003). Form and Substance in Religions. Bloomington: World Wisdom; Schuon, F. (2003). Stations of Wisdom. Bloomington: World Wisdom; Schuon, F. (2003). The Eyes of the Heart: Metaphysics, Cosmology, Spiritual Life. Bloomington: World Wisdom; Schuon, F. (2003). To Have a Centre. Bloomington: World Wisdom; Coomaraswamy, Ananda. (2007). Figures of Speech or Figures of Thought?: The Traditional View of Art. Bloomington: World Wisdom; Nasr, Seyyed Hossein. (1989). Knowledge and the Sacred. Albany: State University of New York Press; Nasr, S. H. (1996). Religion and the Order of Nature. Oxford: Oxford University Press; Nasr, S. H. (1997). Man and Nature: The Spiritual Crisis in Modern Man. Chicago: Kazi Publications; Burckhardt; Titus. (1987). Mirror of the Intellect: Essays on Traditional Science \& Sacred Art. Albany: State University of New York Press; Lings, Martin. (2006). Symbol \& Archetype: A Study of the Meaning of Existence. Cambridge: Fons Vitae; Smith, Huston. (1992). Forgotten Truth: The Common Vision of The World's Religions. New York: HarperCollins; and Smith, H. (2001). Why Religion Matters: The Fate of the Human Spirit in an Age of Disbelief. New York: HarperCollins. 
with our visible and tangible world. Mankind also moved ahead, according to these scholars, and developed a variety of discourses to explain the relationship between the various universes. On the basis of these discourses and doctrines, man also "discovered" a variety of practices and techniques to engage the metaphysical forces of the other worlds. These techniques were sometimes in such a way that their employment would leave certain visible and tangible marks on the "physical" world.

Modern Social Sciences have in general remained silent about the possibility of the existence of such unseen metaphysical structures in the world. In contrast, Traditionalists call for the necessity of opening up to such a possibility. They insist that religions are built around a "real system" that lies beyond human capacity to be fully understood. Evidently, the current ethos of modern Social Sciences is reluctant to take such drastic strides away from the convenient secularized academia. The reluctance might be one of the reasons why Traditionalism, despite more than a century of extensive academic scholarship, remains rather marginalized in the modern academia in the West. At the same time, the core shortcomings of the secular Social Sciences in the study of religions, Traditionalists argue, lie in their hesitation, or inability, to accommodate a Traditionalist perspective.

According to Traditionalists, the disagreement between the secular foundations of the modern Social Sciences on the one hand and religions on the other relates to the Christian background of these Sciences. They argue that an implicit assumption of the modern Social Sciences projects Christianity as the generic religion and its history and fate as the generic history and fate of other religions. The decline of religious observance in Western Europe, therefore, was interpreted as the inevitable future of other religions. 
According to Traditionalists, by remaining caught in Western Europe's experience in regards to religion, the modern Social Sciences have become structurally and psychologically less able to understand the revival of religion. In particular, these Sciences have missed the relative inconsequentiality of the fall of Christianity in Europe for different religious traditions in other parts of the world or even for Christianity in other places. The rather unique stances taken by Traditionalists on issues related to religious traditions have deterred some scholars from engaging in a serious conversation with them. As a result, the Phenomenological approach seems to be the closest modern Social Sciences can get comfortably to a more or less comprehensive study of religion.

Besides these four general approaches, there exists also a body of literature in International Relations that aims at tracing modern secular institutions such as the state back to its religious roots -and particularly to the religious doctrines of the preEnlightenment era. The well-known literature on the Christian roots of Just War theory and secular jus in bello and jus ad bellum and the Augustinian legacy as well as the reference to and the revival of the Natural Law tradition in International Relations are some prominent examples of such literature. ${ }^{117}$ There is also the Schmittian literature on political theology, which interprets sovereignty as an institution of secular divinity. This literature also takes "the concept of the political" to a whole new level in which "the political" is deemed as an existential backbone of man's identity. ${ }^{118}$ Following this

\footnotetext{
${ }^{117}$ See, for instance, the collection of articles on "Ethics of Force" in Hoover et al. (Eds.). Religion and Foreign Affairs. pp. 129-75. The edited volume is a useful collection of some key readings on religion and international relations.

118 See Schmitt, Carl. (1986). Political Theology: Four Chapters on the Concept of Sovereignty. Cambridge: MIT Press; and Schmitt, Carl. (1996). The Concept of the Political. Chicago: University of Chicago Press.
} 
Schmittian tradition, Carlson and Owen deal with post-9/11 sovereignty and the roles religion could play in armed conflicts, military intervention, globalization, justice and human rights. ${ }^{119}$ The dichotomy of the sacred versus the sovereign is explored in the book. This dichotomy, according to Carlson and Owen, is one of the most significant aspects of the rise of religions and religious commitments. Both the modern, Western nation-state and the sacred are self-referential and both demand, according to the authors, complete loyalties from those paying allegiance to them. The result is an almost automatic conflict between the two. Appleby calls the same dilemmatic situation as "Serving Two Masters." 120 The competition between religious God and the secular gods, i.e. modern nation-states, provides certain potential for "constructive" "destructive" impacts of religion on international politics. ${ }^{122}$ One basic question, nevertheless, is whether the underlying tension between "totalism" of religion on the one hand and the "totalitarian" foundation of the modern nation-state on the other is sustainable and containable or not. In any case, this literature, although it engages religion, cannot be properly considered as a literature on religion in international relations. Instead, it functions as an exploration of the sometimes disputed religious roots of secular International Relations and international relations. As such, this particular

\footnotetext{
119 See Carlson, J. D., \& Owens, E. C. (Eds.). (2003). The Sacred and the Sovereign: Religion and International Politics. Washington: Georgetown University Press.

${ }^{120}$ See Appleby, Scott. (2003). Serving Two Masters? Affirming Religious belief and Human Rights in a Pluralistic World. In J. D. Carlson and E. C. Owens (Eds.), The Sacred and the Sovereign: Religion and International Politics (pp. 170-195). Washington: Georgetown University Press.

${ }^{121}$ See the section on the Phenomenological approach above.

${ }^{122}$ M. Mesbahi, Lectures, Fall 2007, and M. Mesbahi, Interviews, Spring 2008.
} 
literature does not extensively contribute to our understanding of the revival of religions in the world and its implications.

In terms of studying religions in International Relations, one particular "barrier of entry" has been the more recent entanglement of religion and security. The introduction of many contemporary International Relations scholars to the question of religion has been through the phenomenon of terrorism. The entanglement, therefore, of International Relations' study of religion with Security Studies literature has been almost by default. In particular, the Security Studies literature on threat perception, non-traditional sources of violence, and fourth-generation warfare has colored the study of religions in the discipline. This in turn has exacerbated the complexities involved in the task of studying religions. The resulting "reductionism" has been paralleled with the tendency among some International Relations scholars to be as "limitationist" or minimalist as possible in the study of religion. The minimalism has encouraged research agendas that follow applied and selective approaches in order to predict the potential consequences of the revival of religions for international security. Such research approaches have sometimes had to compromise the totality of religions as systems of thought and modes of living in favor of immediate concerns for national and global security.

On the basis of the survey of literature on religion in International Relations, my study on the theological foundations of $\mathrm{Sh}^{-}{ }^{‘} \overline{1}$ strategic cultures basically follows the Phenomenological approach as explained above. It attempts to understand as much as possible the fundamental concepts that have shaped Shī'ī perceptions of security and threat as these concepts have been understood by Shī'ah Muslims throughout history. The Phenomenological approach has been chosen because the Enlightenment approach and 
the Identity approach seem to have serious shortcomings in studying religions. These methodological and conceptual shortcomings have rendered them less capable of proper analysis of religions and their roles in today's world. As for the Traditionalist approach, there exist several difficulties that render a Traditionalist research in International Relations especially challenging. In particular, there is no extensive Traditionalist literature in Political Sciences, Sociology, and International Relations at this point that one may engage and to which one may contribute. Nearly all of the currently existing Traditionalist literature lies within the realm of Religious Studies. As yet, it is not clear how the Traditionalist scholarship can be systematically and consistently employed in other branches of the Social Sciences. Nevertheless, this study benefits from some of the Traditionalist insights in the study of Shī'ah Islam. In particular, the presented study of the Shī's notions of Wilāyah and Walāyah in Chapter V would have not been possible without insightful contributions made by Traditionalist scholars who have written on the esoteric foundations of Shī'ah Islam. To summarize, although this study generally follows the Phenomenological approach, it also borrows to the extent possible from Traditionalists in their study of religions in general and Shī‘ah Islam in particular.

\section{Security Studies: Islam and Strategic Culture}

In addition to the general literature on religion in International Relations, this study belongs to a sub-set of literature within Security Studies. In this part, the present study on strategic cultures in Shī'ah Islam will be contextualized in the narrower literature on strategic cultures. As mentioned before, this literature is emerging within the Security Studies in International Relations and strives to understand "the relationship 
between culture and strategy." $" 123$ It asks how culture and cultural institutions affect and shape the strategic perceptions and responses of culturally different actors. There is, therefore, an assumption underlying this literature that claims strategic doctrines and behaviors $^{124}$ are not completely universal. In this context, to the extent that religions have been a building block of various cultures, ${ }^{125}$ this study of strategic concepts in Shī'ah Islam would be a direct contribution to the literature on strategic cultures in International Relations.

The notion of strategic culture goes back to the Cold War era when a number of scholars suggested that some of the Soviet strategic behaviors might have ideological or cultural roots. ${ }^{126}$ Snyder defined strategic culture as the "sum total of ideals, conditional emotional responses, and patterns of habitual behavior that members of the national strategic community have acquired though instruction or imitation and share with each other with regard to nuclear strategy."127 The impacts of the Cold War structure of international relations may be recognized in Snyder's state-centric definition and the

${ }^{123}$ See Johnston, Alastair I. (1995). Thinking about Strategic Culture. International Security, 19(4), 32-64.

${ }^{124}$ Here, strategic doctrines and behaviors refer to those collective doctrines and behaviors that deal with questions of threat, survival, violence, war, and peace.

125 The notion of "culture" has used in a rather broad and loose sense here. In fact, there exist debates around this notion and its use. The author acknowledges, therefore, that there is a certain degree of ambiguity in the definition of "culture." With this acknowledgment in mind, culture implies a "shared knowledge" [see Wendt, A. Social Theory of International Politics] or "shared norm" about a certain practice -for instance act of violence in war or containment of violence by peace. In addition, "culture" partially shapes the meaning of victory and the means towards victory.

${ }^{126}$ M. Mesbahi, Lectures, Fall 2007. For examples of the early studies on the Soviet strategic culture, see Snyder, Jack L. (1977). The Soviet Strategic Culture: Implications for Nuclear Options, R-2154-AF. Santa Monica: Rand Corporation; Jones, David R. (1990). Soviet Strategic Culture. In C. G. Jacobsen (Ed.), Strategic Power: USA/USSR (pp. 35-49). London: St. Martin's Press; and Gray, Colin. (1986). Nuclear Strategy and National Style. Lanham: Hamilton Press.

${ }^{127}$ Snyder, Jack L. The Soviet Strategic Culture. p. 9. 
focus on "nuclear strategy." Nevertheless, the definition acknowledges the possibility of different strategic styles based on non-material forces.

With the collapse of the Soviet Union and the ideologically bifurcated global system, the notion of strategic culture could now be employed in studying the behaviors of various (state or non-state) actors. The post-Cold War world also appeared to be less ideologically organized. As a result, the term "culture" in strategic culture was employed in reference to a broader range of human phenomena including religious belief systems. This broader employment of strategic culture may be found in the post-Cold War conceptualization of strategic culture by one of the so-called "first generation" theorists of the notion. Gray maintains that culture is the "context" of various strategic behaviors. ${ }^{128}$ The "strategic cultural context for strategic behavior,"," in other words, directly and indirectly informs actors and institutions. The more flexible ${ }^{130}$ conceptualization of strategic culture has paved the way for a new generation of studies. These include, for instance, Johnston's study of Chinese strategic culture, ${ }^{131}$ Katzenstein edited volume on culture and national security; ${ }^{132}$ Kier's study of French and British

\footnotetext{
${ }^{128}$ Gray, Colin. (1999). Strategic Culture as Context: The First Generation of Theory Strikes Back. Review of International Studies, 25, 49-69.

${ }^{129}$ Ibid. p. 50.

${ }^{130}$ Black, for instance, argues that the notion of strategic culture "depends for its applicability on a degree of flexibility" [see Black, Jeremy. (2004). Rethinking Military History. New York: Routledge. p. 142].

${ }^{131}$ Johnston, Alastair I. (1995). Cultural Realism: Strategic Culture and Grand Strategy in Chinese History. Princeton: Princeton University Press.

${ }^{132}$ Katzenstein, Peter J. (Ed.). (1996). The Culture of National Security: Norms and Identity in World Politics. New York: Columbia University Press
} 
culture-doctrine nexus between the World Wars; ${ }^{133}$ Krause's edited volume on the role of cultural factors in disarmament and arms control; ${ }^{134}$ Duffiled's study of the post-Cold War non-Neorealist security strategy of Germany; ${ }^{135}$ Glenn et al.'s edited volume on national strategic cultures in India, Nigeria, Japan, Australia, Russia and Germany; ${ }^{136}$ Sondhaus's study of national "ways of war"; ${ }^{137}$ Mufti’s study of Turkish "Republic" strategic culture; ${ }^{138}$ and a number of studies on European Union's emerging -or projected- strategic culture. ${ }^{139}$

133 Kier, Elizabeth. (1997). Imagining War: French and British Military Doctrine between the Wars. Princeton: Princeton University Press.

${ }^{134}$ Krause, Keith R. (1999). Culture and Security: Multilateralism, Arms Control and Security Building. New York: Frank Cass Publisher.

${ }^{135}$ Duffield, John S. (Autumn 1999). Political Culture and State Behavior: Why Germany Confounds Neorealism. International Organization, 53(4), 765-803.

${ }^{136}$ Glenn, J., Howlett, D., \& Poore, S. (Eds.). (2004). Neorealism versus Strategic Culture. Burlington: Ashgate Publishing. The book offers an insightful and rich review of Neorealism and "Culturalism" in the study of national security. Although the following six case studies of the book do not directly engage the full range of the Neorealist-Culturalist debate, they all indicate the impacts of historical and cultural forces in shaping various national security doctrines.

${ }^{137}$ Sondhaus, Lawrence (2006). Strategic Culture and Ways of War. New York: Routledge. The book is an example of a genre of writing within the strategic culture literature that specifically focuses on various national cultures of war -and national attitudes towards military forces. Other examples of such studies include Black, Jeremy. Rethinking Military History, Farrell, Theo. (2005). The Norms of War: Cultural Beliefs and Modern Conflict. Boulder: Lynne Rienner; Buley, Benjamin. (2008). The New American Way of War: Military Culture and the Political Utility of Force. New York: Routledge. Adamsky, Dima. (2010). The Culture of Military Innovation: The Impact of Cultural Factors on the Revolution in Military Affairs in Russia, the US, and Israel. Stanford: Stanford University Press; Black, Jeremy. (2012). War and the Cultural Turn. Cambridge: Polity Press; and Johnson, Robert. (2012). The Afghan Way of War: How and Why They Fight. New York: Oxford University Press.

${ }^{138}$ Mufti, Malik. (2009). Daring and Caution in Turkish Strategic Culture: Republic at Sea. New York: Palgrave Macmillan.

${ }^{139}$ See, for instance, Meyer, Christoph O. (2006). The Quest for a European Strategic Culture: Changing Norms on Security and Defence in the European Union. New York: Palgrave Macmillan; and Toje, Asle. (2008). America, the EU and Strategic Culture: Renegotiating the Transatlantic Bargain. New York: Routledge. 
Buzan et al. offer a new framework for studying the notion of security. This framework involves a "securitizing agent," for example states, international organizations, or religious authorities that, through a successful speech act, establishes the perception of an existential threat. This threat is articulated within one or more "security sectors," including political, military, societal, cultural, environmental or economic. The main thrust of a securitizing speech act is to claim that the source of the threat is existentially endangering a valued "referent object" such as a country, a culture, the environment, a religion, or an ethnic group. ${ }^{140}$ Therefore, the process of securitization has to engage some cultural and social elements in order to be successful. The cultural dimension of securitization is why, according to these authors, war as the ultimate measure or response to the securitization of an object also involves some cultural and social aspects. War is deemed as a totalizing phenomenon that engages all muscles of the parties involved. The totalizing nature of war implies some culturally specific as well as some universal aspects.

The particularity of each collective act of violence may arise from particular cultures involved in the act. At the same time, all collective acts of violence show some common features. For example, certain common elements in all strategic cultures have appeared due to the pragmatic concerns for functionality. Throughout history, various cultures have copied each others' strategic behaviors and doctrines. For instance, LiddellHart's "indirect approach" that emphasizes speed and maneuverability became one element of a "thin universal strategic culture" in the last century. ${ }^{141}$ The Sun Tzuean and

\footnotetext{
${ }^{140}$ See Buzan et al., Security: A New Framework for Analysis.

${ }^{141}$ See Liddell-Hart, Basil H. (1991). Strategy. New York: Penguin Books.
} 
economical element of surprise aimed at destroying enemy's physical and mental equilibrium was soon copied and adopted by various cultures around the globe. In a similar vein, blitzkrieg became a universal element of strategic cultures due to its success during the Second World War. Mearsheimer goes further to argue that most modern conventional wars have shown three common and general strategies: attrition to exhaust the enemy, limited aims strategies, and, indeed, blitzkrieg. ${ }^{142}$ In addition to these common strategies, the evolution of warfare from the first generation to the fourth generation has produced universally adopted practices and doctrines. ${ }^{143}$

Most of these generic aspects of strategic cultures are rooted in technological development, strategic inventions, and functionality. The first generation warfare brought with itself a generic military culture of ranks and military-civilian distinctions. The monopoly of state in using systemic violence to achieve political objectives was also strengthened. The second generation of warfare brought by itself the practice of indirect fire, psychological and radio warfare rooted in technological development or strategic innovation. The third generation introduced universal elements of mechanized warfare (technology), new methods of using military technology such as blitzkrieg (strategy), and the increased role of surprise and speed. The fourth generation of warfare, however, has been more problematic. It challenged the monopoly of states in employing systemic violence and, in doing so, partially shaped a new universal strategic culture. ${ }^{144}$

\footnotetext{
${ }^{142}$ See Mearsheimer, John J. (1983). Conventional Deterrence. Ithaca: Cornell University Press.

${ }^{143}$ The following discussion of the generations of warfare has been adopted from Professor Mesbahi's lectures in his gradate seminar on Security and Strategic Studies in Fall 2007.

${ }^{144}$ M. Mesbahi, Lectures, Fall 2007.
} 
As militarily and technologically weaker actors began to accommodate elements of the fourth generation warfare, the stronger players also developed counter-strategies such as counter-revolutionary and counter-guerrilla warfare. ${ }^{145}$ Again, one unintended consequence has been the spread of similar doctrines and practices around the globe, including the blurring boundary between civilians and military personnel, between zones of conflict and those of peace, and between military campaigns and political processes of nation- or state-building. ${ }^{146}$

Another more or less universal aspect of strategic cultures emerged in the last century has been the extremely totalizing image of war. ${ }^{147}$ War was deemed as a practice that engaged various aspects of a society's life from military to politics, economics, financial networks, culture, education and, in cases where religion was involved, the socalled "cosmic level." The religious element projected an "essentialist" fight between the forces of good and the forces of evil. Within this context, an alternative generic strategic culture appeared. Mesbahi calls this alternative a generic strategic culture of "resistance."148 The examples of universally adopted techniques and doctrines of resistance ranged from Mao's manual for guerrilla-warfare and techniques of hit-and-run, to Lawrence's prescription for defeating the enemy without engaging its main force, to

\footnotetext{
${ }^{145}$ Ibid.

${ }^{146}$ See Connor, Walker. (1972). Nation-Building or Nation-Destroying?. World Politics, 24(3), 319-355.

${ }^{147}$ I am indebted to Professor Mesbahi for the following analysis of the universal transformations in the conceptualization and actual practice of war. The general framework of this discussion regarding the thin universal strategic culture, its historical trajectory, and the consequential effects of fourth generation warfare on it are, in particular, the results of Professor Mesbahi's informative comments and lectures [M. Mesbahi, Lectures, Fall 2007, and M. Mesbahi, Interviews, Spring \& Fall 2008].
}

${ }^{148}$ M. Mesbahi, Lectures, Fall 2007, and M. Mesbahi, Interviews, Spring 2008. 
Castro's techniques of revolutionary warfare. All these techniques transcended cultural and geographical differences and generated a generic strategic culture of resistance. Indeed, each local revolutionary group changed and modified certain aspects of these guidelines in order to accommodate geographical, cultural, political, and economic contingencies. Nevertheless, certain generic elements remained in place.

Along with these transformations, some developments also happened in the nature of war that, in turn, affected various strategic cultures universally. ${ }^{149}$ Examples of these transformations include introduction of electronic warfare, joint campaigns, encryption techniques, and development of various "Special Forces." Yet, most of these generic -and technical- elements of strategic cultures were unintended consequences of technological developments, strategic innovations, or functional successes. In contrast, one of the first major attempts in modern time to create a generic strategic culture by design happened in 1648 C.E. in Westphalia. Following decades of religious wars, the Treaty of Westphalia monopolized the states' right to resort to violence. The Treaty also fortified a universal notion of nonintervention by sanctioning the concept of sovereignty. War appeared as one of the resources exclusively at the disposal of the newly-born institution of modern state. It became Clausewitzian -or purely instrumental- war, or the "continuation of politics by other means." Westphalia marked the end of the mercenary strategic cultures of the Middle Ages, the "absolutist" strategic cultures of the Reformation, or the elaborate and ceremonial strategic cultures of the demising European nobilities. The new generic strategic culture was evolved and further solidified in 1713 C.E. by the Utrecht Treaty in

\footnotetext{
${ }^{149}$ For an overview of these changes see Cohen, Eliot A. (1996). A Revolution in Warfare. Foreign Affairs, 75(2), 37-54.
} 
which "balance of power" was recognized as a pillar of European politics and a foundation of peace in Europe. As mentioned before, in this European strategic culture, war was deemed an accepted leverage to keep the "balance" in place.

Napoleon contributed to the next major development in the generic strategic culture. Mesbahi argues that Napoleon turned the Hobbesian notion of state on its head. ${ }^{150}$ It was no longer the state's responsibility to provide its subjects or citizens with security. Instead, it was the citizens' responsibility to protect and secure the state. As many scholars of strategic cultures have noticed, the Napoleonic wars brought the notion of "nations in arms" to the center of an increasingly universal strategic culture. According to Mesbahi, this development totalized -or "absolutized"- the notion of war within various strategic cultures. ${ }^{151}$ The transformation also glorified the practice of war in a sharp contrast to the Clausewitzian "instrumentalist" conceptualization of the practice. Yet the enormous costs of engagement in a prolonged state of war involving the whole population proved to be unsustainable. This led to re-appreciation of the notion of balance of power in European strategic cultures as the foundation of peace. Many Western strategists and thinkers of Classical Realism such as Kissinger, Carr, Kennan, and Morgenthau saw war as more or less something devoid of any majesty and awe.

Another consequential development took place during the Paris Peace Conference in 1919 following the First World War. An implicit universal notion appeared that, at least on the level of propaganda, projected war as a criminal act. The language adopted by the League of Nations almost equated war with aggression. This was to usher in an important

\footnotetext{
${ }^{150}$ M. Mesbahi, Lectures, Fall 2007.

${ }^{151}$ Ibid., and M. Mesbahi, Interviews, Spring \& Fall 2008
} 
change of language within the universal strategic culture; for various strategic cultures around the globe followed the anti-aggression language that had aimed at de-normalizing war-albeit without any substantial change in strategic doctrines and behaviors. ${ }^{152}$

Carr famously attacked the conceptualization of war within some of the more sanguine liberal strategic cultures. In his The Twenty Years' Crisis, Carr argued that the League of Nations had mistaken the absence of war for a stable and sustainable peace. ${ }^{153}$ The League had wrongly assumed, in other words, that the status quo was acceptable to all. Carr also denied that non-violence was a permanent possibility. He asserted that the proposed "international law" would simply remove war as an instrument at the disposal of states to protect their security and to maintain the balance of power without providing any effective substitute. It was the adoption of this new strategic culture by some European powers that led, according to Carr, to the Second World War. Therefore, Carr and other Classical Realists argued for a cautious "re-normalization" of war as an undesirable yet necessary instrument. Following the Second World War, most strategic cultures around the globe seemed to have accepted a similar image of war as the "ultimate instrument of foreign policy" or the so-called "last resort." In unusual symbioses, therefore, different and inconsistent elements of the Clausewitzian "instrumentalist" notion of war, the Napoleonic totalized notion of war, the liberal anti-

\footnotetext{
${ }^{152}$ Angell offers a classic account of this pre-First World War liberal philosophy. See Angell, Norman. (1972). The Great Illusion: A Study of the Relation of Military Power in Nations to Their Economic and Social Advantage. New York: Arno Press.

${ }^{153}$ Carr, E. H. (2001). The Twenty Years' Crisis 1919-1939: An Introduction to the Study of International Relations. New York: Palgrave Macmillan.
} 
war discourse, and the Classical Realists' war-as-the-last-resort notion began to appear in various strategic cultures.

Meanwhile, nuclear weapons disturbed the universal and local strategic cultures. Many strategic analysts believed that the nuclear technology had led to a qualitative change. In contrast to almost all other elements within different conventional strategic cultures, a nuclear war could not have a meaningful objective, they argued. Brodie and others developed a new strategic paradigm for the nuclear age. They declared that such weapons made total wars obsolete. ${ }^{154}$ The change called for a major adjustment in various strategic cultures. At the same time and on a more practical level, the doctrine of nuclear deterrence appeared to be more powerful compared to conventional deterrence. On the more philosophical and moral level, however, a taboo soon began to emerge around nuclear weapons. The weapons' massive scale of destructive power made them a different and disturbing category. Caught between pragmatic concerns and grave moral consequences, many strategic cultures responded hypocritically to the nuclear age as onthe-surface condemnation of the expansion of nuclear weaponry became more or less a universal practice. It must be mentioned, however, that there is a counter-argument against the half-normative, half-pragmatist treatment of nuclear arms. Waltz, for instance, claims that a certain "sobering" and universal effect is embedded in the process of becoming a nuclear power. Not surprisingly, Waltz' problematic claim has come under serious attacks by his critics. ${ }^{155}$

\footnotetext{
${ }^{154}$ See Steiner, Barry H. (1991). Bernard Brodie and the Foundations of American Nuclear Strategy. Lawrence: University of Kansas Press.

${ }^{155}$ See Sagan, Scott D., \& Waltz, Kenneth N. (2002). The Spread of Nuclear Weapon: A Debate Renewed. New York: WW Norton \& Co.
} 
As we review the universal changes that took place in various strategic cultures, it is worth paying some attention to the consequences of the Vietnam War. In particular, Vietnam gave birth to a modern just war theory that, in turn, shaped the discourse and paradigms of various strategic cultures. Michael Walzer developed a secular version of jus ad bellum and jus in bello. He employed the old analogy between individual and state and their corresponding rights. ${ }^{156}$ The foundation of his just war theory, therefore, was no longer Christian Natural Law tradition and the affiliated notion of "obligations." Instead, the modern articulation of the notion of natural rights, which had been popularized by, inter alios, John Locke, served as the theoretical foundation for Walzer's theory. Since all states must provide a minimum level of security for their citizens, Walzer argued that war of self-defense is inherently legitimate. At the same time, he qualified this claim by including the principle of proportionality and that of distinction between civilian and military targets. The two principles soon became the pillars of just war discourse in various strategic cultures. This was yet another layer of legal turns in strategic paradigms that tried to distinguish between "aggression" and "self-defense." In nearly all the wars of the past couple of decades, the parties involved have accused the other side to be the aggressor while justifying their own actions on the ground of self-defense.

Beyond these generic elements borrowed and adopted by various strategic cultures, there have been exclusive elements in a number of local strategic cultures. These specific items and discourses arise from unique cultural settings and historical trajectories. It is the study of these culturally specific features and their roots that has

\footnotetext{
${ }^{156}$ See Walzer, Michael. (2006). Just and Unjust Wars: A Moral Argument with Historical Illustrations. New York: Basic Books.
} 
been the research focus of strategic culture literature. For instance, Japan and Germany embarked on an aggressive social re-construction of their strategic cultures following the Second World War. ${ }^{157}$ Both countries aimed at transforming their respective strategic cultures from a militaristic one towards a culture built around "trading states."

Similar to the cases of Germany and Japan, it is possible to distinguish several other national strategic cultures in today's world. For instance, Israelis developed an early strategic culture rooted in religious imageries and theological discourses. Mesbahi argues that the image of weak David played a crucial role in shaping young Israel's strategic culture when the newly-born state perceived itself as weak and vulnerable under existential threat. ${ }^{159}$ Although the decisive military successes of Israeli army in the 1960s and the 1970s decreased the relevance of the Davidian image, Israeli strategic culture has remained distinct in many aspects as Israel continues to see itself in an exceptionally hostile environment. China under Mao also developed a distinct strategic culture. Johnston argues that Maoist China combined elements of Confucianism, Sun Tzu's teachings, and Marxism with lessons from Chinese historical experiences. Underlying this symbiosis was the Cold War image of the world as a zero-sum battlefield between

\footnotetext{
${ }^{157}$ See Berger, Thomas U. (1996). Norms, Identity, and National Security in Germany and Japan. In P. J. Katzenstein (Ed.), The Culture of National Security (pp. 317-356). New York: Columbia University Press. For more recent studies of Japanese and German strategic cultures, see Glenn, J., Howlett, D., \& Poore, S. (Eds.). Neorealism versus Strategic Culture. pp. 129-52; and Ibid. 204-23. For an insightful analysis of Japanese strategic culture prior and during the Second World War and how culture shaped strategic perceptions in Imperial Japan, see Morgan, Forrest E. (2003). Compellence and Strategic Culture of Imperial Japan: Implications for Coercive Diplomacy in Twenty-First Century. Westport: Praeger Publishers.

158 See Rosecrance, Richard. (1986). The Rise of The Trading States: Commerce and Conquest in the Modern World. New York: Basic Books.

${ }^{159}$ M. Mesbahi, Lectures, Fall 2007.
} 
Capitalism on the one hand and Communism on the other. ${ }^{160}$ The resulting Chinese "offensive realism," according to Johnston, did not develop based on structural calculations. Instead, it was rooted in the multi-faceted cultural background of Maoist China. In a similar vein, Lenin developed a Marxist version of just war theory. Believing that Communism cannot survive in one country and that expansion of Marxism is a necessity, Lenin argued for a distinct strategic culture that condoned violence if it facilitated the emergence of universal Communism. According to Mesbahi, this ideologically specific strategic culture was in line with Lenin's forceful "volunteerism."161 An assertive "volunteerist," Fanon also believed that violence is an inherent and "just" part of anti-colonial resistance. ${ }^{162}$ A similar line of thought gave birth to several nationalistic and socialist strategic cultures that viewed violence as inevitable means towards a justified goal.

Finally, the United States has also developed a unique strategic culture. Similar to other specific strategic cultures, the United States' strategic culture is a symbiosis of various distinct discourses and paradigms added to the generic elements of strategic cultures. ${ }^{163}$ In particular, the United States has adopted and combined discourses of

\footnotetext{
${ }^{160}$ See Johnston, Alastair I. (1996). Cultural Realism and Strategy in Maoist China. In P. J. Katzenstein (Ed.), The Culture of National Security (pp. 216-268). Following the collapse of the Soviet Union and the so-called "rise of China," there has been more interest in studying Chinese strategic culture. See, for instance, Zhang, Shu Guang. (1992). Deterrence and Strategic Culture: Chinese-American Confrontations, 1949-1958. New York: Cornell University Press; and Feng, Huiyun. (2007). Chinese Strategic Culture and Foreign Policy Decision-Making: Confucianism, Leadership and War. New York: Routledge.

${ }^{161}$ M. Mesbahi, Lectures, Fall 2007, and M. Mesbahi, Interviews, Spring 2008. For a post-Cold War study of Russian strategic culture, see Glenn, J., Howlett, D., \& Poore, S. (Eds.). Neorealism versus Strategic Culture. pp. 173-203.

${ }^{162}$ See Fanon, Frantz. (2004). The Wretched of the Earth. New York: Grove Press.

${ }^{163}$ Given the technological superiority that the United States achieved towards the end of the nineteenth
} 
"exceptionalism," "utopianism," "legalism," and "isolationism" in its formulation of foreign policy, and thus in the creation of its strategic culture. ${ }^{164}$ In the twentieth century, Gaddis argues that the Pearl-Harbor experience restarted the forces of expansion, "unilateralism" and hegemony in American strategic culture. These responses, he claims, are the generic reaction to a surprise attack in American strategic culture. ${ }^{165}$ Others emphasize the role played by the Vietnam War that ended the post-World War II strategic paradigm in the United States and led to what Roskin calls the "Vietnam generational paradigm" of non-intervention. ${ }^{166}$ The unexpected end of the Cold War, according to Mesbahi, contributed to an era of “triumphalism" in the United States' dynamic strategic culture. ${ }^{167}$ It was in the context of this updated strategic culture that the first Persian Gulf War was framed as a legitimate response by the community of states (under the United States' leadership) to Iraq's violation of international law. The second Persian Gulf War, however, illustrated a significant transformation that had taken place in American post-

century, one may expect that technology has played an important role in shaping American strategic culture. In fact, a combination of technological military advancements and cultural dynamics has led to emergence of an American "strategy of technology" that "postulates the achievement of victory through application of scientific principles and technological means alone" [see Harris, Brice F. (2009). America, Technology and Strategic Culture: A Clausewitzian Assessment. New York: Routledge. p. 153]. See also Mahnken, Thomas. (2008). Technology and the American Way of War Since 1945. New York: Columbia University Press.

${ }^{164}$ See Mead, Walter R. (2002). Special Providence: American Foreign Policy and How It Changed the World. New York: Routledge.

${ }^{165}$ See Gaddis, John L. (2004). Surprise, Security, and the American Experience. Cambridge: Harvard University Press.

${ }^{166}$ See Roskin, Michael. (1999). From Pearl Harbor to Vietnam: Shifting Generational Paradigms and Foreign Policy. In G. J. Ikenberry (Ed.), American Foreign Policy: Theoretical Essays (pp. 315-336). New York: Longman.

${ }^{167}$ M. Mesbahi, Lectures, Fall 2007, and M. Mesbahi, Interviews, Spring 2009. 
9/11 strategic culture. It showed a departure from the principle of non-intervention in American strategic culture. ${ }^{168}$

The various strategic cultures that have appeared around the globe have not been completely unique. They indeed have been consciously and unconsciously influenced by the universal strategic doctrines and practices. We have already recognized these universal elements as a thin universal strategic culture in which various branches of local strategic cultures have their roots. In this context, Islam has also partially shaped various strategic cultures in different Muslim societies. For instance, some scholars argue that within the Muslim version of just war theory, it is speculated that Muslims may be the unjust party involved in war. ${ }^{169}$ Other elements of Muslim religious beliefs, theological doctrines, and jurisprudential rulings have historically shaped Muslim strategic cultures. Meanwhile, a family of distinct strategic cultures appeared in Shī‘ah Islam. The emergence of these cultures was the result of a variety of causes including the historical trajectory of Shī'ah community and their level of access to political power. In particular, the experience of Shī'ah Muslims living for a long time as a minority group has colored these strategic cultures. On the other hand, Shī'ah Muslims' understanding of Islam and their version of the religion provided the theological foundation for these unique strategic cultures. The result of this symbiosis of history and theology has been Shī'ī strategic

\footnotetext{
${ }^{168}$ This, of course, does not mean that non-intervention has always been the determining factor in shaping the United States' strategic decisions. Instead, the principle of non-intervention has been one of a number of paradigms and discourses that have shaped such decisions.

${ }^{169}$ See, for instance, El Fadl, Khaled Abou. (2002). The Place of Tolerance in Islam. Boston: Beacon Books.
} 
perspectives that show noticeable differences compared to those of the majority Sunnī Muslims.

Vali Nasr and Roy Mottahedeh both notice the centrality in Shī'ah history of the killing of the third Shī'ah Imām, the Prophet's grandson, in Karbalā in the seventh century. ${ }^{170}$ The event gave more visibility to Shī'ahs as a religious community conscious of its minority status within the larger Muslim community. As a result, notions such as resistance, pain, suffering, and martyrdom embodied in the story of the Prophet's grandson were established in Shī'ah theology and, later on, in Shī's̄ strategic cultures. As will be discussed later, however, the foundation of Shī' $\overline{1}$ strategic cultures goes further back to the time of the Prophet. The root of these distinct strategic cultures is in the way 'Alī, the first Shī'ah Imām, and few other companions of the Prophet understood the Prophet's message. It is true that one of the central pillars of Shī' ${ }^{\top} \overline{1}$ strategic cultures has been the notion of Shahādah ${ }^{171}$ embodied in the dramatic events of Karbalā. It is also true that the historical experience of the Shī'ah community as a persecuted and harassed minority following the Battle of Karbalā led to the rise of cautionary doctrines such as Taqīyyah ${ }^{172}$ in $S^{S} \overline{1}^{`}$ ah theology and $\operatorname{Sh}^{\top}{ }^{`} \overline{1}$ strategic cultures. Yet, these two elements of

\footnotetext{
${ }^{170}$ See Nasr, Vali. Shi ' a Revival; and Mottahedeh, Roy. (2000). The Mantle of The Prophet: Religion and Politics in Iran. Oxford: Oneworld Publications. More detail about this event and the theological and doctrinal consequences of it are provided in Chapter III.

171 The doctrine of Shahādah, or martyrdom, divorced the notion of victory from worldly gains and concrete results. The doctrine separated moral victory from physical victory, valuing the former and belittling the latter. This was in line with Shī'ah Muslims' minority status and their limited access to political or military success in their early history. A more extensive discussion of the Shī'i doctrine of martyrdom, its features in contrast to a similar notion in Sunnī Islam, and its place in Shī'ì strategic doctrines is offered in Chapter III.

${ }^{172}$ The doctrine of Taqiyyah established both in Shī'ah orthodoxy and orthopraxy the principle of prudence and precaution. The doctrine was developed by Shī'ah Imāms and Shī'ah theologians in early centuries of Shi' ${ }^{`}$ ah Islam as a survival strategy in response to an increasingly hostile environment. As expected, this
} 
Shì`ī strategic cultures, namely Shahādah and Taqīyyah, could have not coexisted without the ontology of Wilāyah and Walāyah. ${ }^{173}$ The roots of the Shī'ī notions of Wilāyah and Walāyah go back to 'Alī and his companions' understanding of the core message of the Prophet. The centrality of Wilāyah and Walāyah in the Shī‘ah-Sunnī split has sometimes been neglected by reduction of the split to a matter of political succession to the Prophet. However, a proper understanding of Shī's strategic cultures is not possible without revisiting the notions of Wilāyah and Walāyah. Among these three central notions of Shī‘ $\overline{1}$ strategic cultures, the literature on Shī'ah Islam has often focused on the first, namely the doctrine of Shahādah. The focus has been, partly, the result of the emergence of Iran's "Islamic state" and the following eight-year war between Iran and Iraq. In fact, Mesbahi argues that during the long War, martyrdom became a powerful element of the Iranian strategic culture. He goes further to argue that, during the War, the "backbone of Iran's national security" became the doctrine of Shahādah. ${ }^{174}$

In contrast to most of the cases of strategic cultures reviewed above, Shī's strategic cultures are not necessarily "national" strategic cultures. Instead, these strategic cultures informed the collective attitudes of various Shī'ī communities and their -

proved to be an extremely powerful doctrine and a version of Shī‘i "principlism" emerged along with it as a "controlling" paradigm. A more extensive discussion of the Shī'i doctrine of Taqìyyah, its features and its limitations including the Shī'ì paradigm of principled action, as well as Taqīyyah's place in Shī'ah strategic doctrines is offered in Chapter IV.

${ }^{173}$ The notions of Wilāyah and Walāyah respectively articulate the exoteric and esoteric dimensions of Shi' 'ah ontology and refer to the spiritual hierarchy of the world via which the Grace of God is bestowed upon man. The two have been among the most central Shī'i theological doctrines and constitute an original point of distinction between Shī'ah and Sunnī versions of Islam. A more extensive discussion of the Shī's notions of Wilāyah and Walāyah as well as their foundational place in Shī'ī strategic doctrines is offered in Chapter V.

${ }^{174}$ M. Mesbahi, Interviews, Spring 2010, and Mesbahi, Mohiaddin. (Spring 2011). Free and Confined: Iran and the International System. Iranian Review of Foreign Affairs. 2(5), 9-34. 
religious and political- leaders when it comes to the issue of survival. The fact that the early Shī'ah community was the victim of persecution for a long period of time meant a constant preoccupation in the community about their survival. This preoccupation brought into the fore the type of questions that lie at the heart of any strategic culture. The resulting metaphors and strategies of survival then constituted the content of Shī'i strategic cultures.

It must be re-emphasized that the nationally, religiously, or ideologically specific strategic cultures are often embedded in the thin generic strategic culture discussed above. Specific cultures have been eclectic in picking and choosing certain generic elements; and they have developed unique packages of "norms and values" as well as "strategies and models" $" 175$ regarding the notions of security, threat, survival, and the use of force. Therefore, to talk about specific Shī‘ī strategic cultures does not mean to neglect or deny generic elements that $S^{\top} \overline{1}^{`} \overline{1}$ actors may have adopted in their strategic doctrines and practices. Similar to any other local strategic culture, Shî'ī strategic cultures include various universal elements. Many of these universal elements have been rooted in historical experiences and doctrinal innovations. Examples include the Clausewitzian "instrumentalist" approach to war, the Napoleonic absolutized image of war, the liberal anti-war paradigm, the Realist accommodation of war as the last resort, resistance and revolutionary warfare as well as various elements of the universal notion of just war. Despite these universal factors, however, Shī‘ī strategic cultures have their unique themes rooted in Shī'ah Muslims' historical experience and in Shī'ah theology. My dissertation is, therefore, a contribution towards understanding the theological foundations of these

\footnotetext{
${ }^{175}$ See Katzenstein, Peter J. (Ed.). The Culture of National Security.
} 
specific strategic cultures while paying attention to the accompanying historical developments.

\section{Shī‘ah Studies: Shī‘ah and Orientalism}

The rising significance of religions in today's social and political environment has led to the engagement of Religious Studies literature by scholars in other branches of Social Sciences. In terms of Islamic Studies in general and Shī'ah Studies in particular, this has sometimes meant a rather uncritical reading of a literature partly shaped by “Orientalism." Despite important contributions that "Orientalist" scholars have made to our understanding of Muslim world and Muslim history, the school of thought has certain limitations. These limitations may become particularly consequential when the "Orientalist" perspective is being applied to the study of Islam in other branches of Social Sciences such as International Relations. When it comes to the study of Shì'‘ strategic cultures, having a phenomenological perspective is essential in the study of the subject. Among all the limitations of the "Orientalist" school of thought, the most relevant to the subject of this dissertation is that "Orientalists" explicitly or implicitly project Shī'ah Islam as "Shī'īsm" and/or as an ideological "sect." In fact, this conceptualization of Shī‘ah Islam has a close affinity to the Identity approach discussed above. It, therefore, shares some of the general limitations of the Identity approach in the study of religion.

Madelung, for instance, offers a review of the early religious schools and "sects" in Islam. ${ }^{176} \mathrm{He}$ juxtaposes "Shī'îism" and "Khārijīsm"177 as two early Islamic

\footnotetext{
${ }^{176}$ See Madelung, Wilferd. (1985). Religious Schools and Sects in Medieval Islam. London: Variorum Reprints; and Madelung, Wilferd. (1988). Religious Trends in Early Islamic Iran. Albany: State University of New York Press. In Madelung, Wilferd. (1992). Religious and Ethnic Movements in Medieval Islam. Hampshire: Variorum, reader can find some of Madelung's works on early Islamic eschatology.
} 
movements. ${ }^{178}$ Such categorization of Shī'ah Islam is consequential and leads to the treatment of Shī'ah (Imāmī) Islam as a "sect." In fact, this Shī'ah-as-a-sect approach has not been uncommon within Oriental Studies. The formulation was used, later on, to partially fill the knowledge deficit in International Relations about Islam in general and about Shī'ah Islam in particular. The popularity of the "Orientalist" reading of the Shī'ahSunnī split among International Relations scholars has been partly because these scholars seem to be analytically more comfortable in using political notions such as sects. The familiar language would obviate digging into more difficult questions of theology and religion. The result has been the emergence of a mainstream "Orientalist" International Relations literature on Shī'ah Islam. As the corollary to this, terms such as "sectarian violence” have appeared in Security Studies to understand Sh̄̄'ah-Sunnī dynamics within the Identity approach.

One of the most influential founding fathers of Oriental Studies in the West is Ignác Goldziher. The extent of meticulousness and diligently wrought fine details in his

\footnotetext{
177 "Khārijīsm" refers to the Khawārij, a movement that gained visibility in the final years of "Alī's rule as the fourth Muslim caliph. The original Khawārij may be considered among the earliest violent extremist groups in Muslim history and the first major Takfirin group, i.e. those declaring [other Muslims] disbelievers [upon committing a sinful act]. The Arabic term Khawārij is the plural for Khārijī that literally means "one who has gone out" or "one who is outside." The label is an indication of mainstream Muslims' rejection of the movement and its principles. The literalist and strictly Sharī'ah-oriented Khawārij initially supported 'Alī's caliphate against his major challenger, Mu'āwīyah ibn Abī Sufyān. They soon, however, turned against 'Alī and took issue not only with his political decisions but also with his interpretation of Islam -an interpretation that was to serve as one of the main foundations of Shi' $a$ ah Islam and Sh'`'ah theology. This is why throughout history Shī'ah Muslims took strong stances against the Khawārij. Eventually, 'Alī was assassinated by one of the fanatic members of the Khawārij. In the centuries that followed, the Khawārij divided into various groups such as Azāriqah and Yamāmah and gradually faded away [see Feirahi, Davoud. (2009). Tārīkh Tahawwūl Duwlat dar Islām. Qum: Intishārāt Dānishgāh Mufīd. pp. 236-7; Ahmad ibn Abī Ya'qūb, Tārīkh Ya 'qūbī, Vol. 2, pp. 191-3; and Abū al-Fatḥ Shahristānī, al-Milal wal-Nihal. Vol. 1, pp. 114-37].The group has continued its fringe existence to this day and has steadily become softer in its doctrines and practices to the extent that today's main descendants of the Khawārij are the peaceful 'Ibādīs residing in Oman as well as some smaller communities living in parts of North Africa.

${ }^{178}$ See Madelung, Wilferd. Religious Schools and Sects in Medieval Islam. p. 128.
} 
works should be seen as the signature of the early generation of Oriental Studies in Europe. ${ }^{179}$ The scrupulous examination of ancient Muslim texts, which was the hallmark of these early Oriental Studies, was more or less lost in the works of later generations of "Orientalist" scholars. Writing more than a century ago, Goldziher's list of research interests and questions may appear outdated. His exhaustingly objective style, however, is still of major benefit for anyone who wishes to study Islam, especially within the Identity or Phenomenological frameworks. At the same time, the early Oriental Studies sophistication contrasts to some "reductionist" generalizations that became the feature of the works of "Orientalists" such as Bernard Lewis. Despite his nuanced scholarship, however, Goldziher still views Shī‘ah Islam -or what he calls "Shī‘īsm"- as a sect. It is implied, therefore, that Shī'ah religious doctrines have been formulated and articulated a posteriori by Shī‘ah Muslims to theorize an essentially political dispute. Goldziher even goes further and concludes that Shī'ah Islam is a diversion from the Islamic orthodoxy; and that it potentially contradicts the basic conceptualization of God in Islam.

Based on the "Orientalist" historiography, Madelung turns his attention to the politics of the Shī'ah-Sunnī split and deals with the historical debate over the succession of the Prophet. ${ }^{180}$ Unlike the mainstream "Orientalist" literature, Madelung offers a rather sympathetic account of the early history of Shī'ah Islam; and his historiography comes close to that of mainstream Shī'ah Muslims. He presents 'Alī as an "idealist" and a true believer caught among some "consummate, coolly calculating" power-seeking political

\footnotetext{
${ }^{179}$ See in particular Goldziher, Ignác. (2006). Muslim Studies (Vol. I). Chicago: Aldine Publishing; and Goldziher, Ignác. (1971). Muslim Studies (Vol. II). New York: Aldine Publishing.

${ }^{180}$ See Madelung, Wilferd. (1997). The Succession to Muhammad: A Study of the Early Caliphate. Cambridge: Cambridge University Press.
} 
actors. ${ }^{181}$ In his historiography, however, the consequential and doctrinal differences between Shī‘ah Islam and Sunnī Islam, which are necessary for proper understanding of the later developments, are overshadowed by the focus on politics. Issues such as political authority, legitimate sovereignty, and justice on the exoteric level of the Shī'ahSunnī split are underscored at the expense of esoteric questions of Wilāyah, Walāyah, Divine Justice, and metaphysical hierarchies. The implicit consensus, therefore, has been that $\operatorname{Sh}^{\top}{ }^{\prime} \overline{1}$ theological edifice was a later development providing a justification or explanation for the early political split of the Shī'ah Muslims from the majority of the Muslim community. 'Alī’s exoteric and esoteric formulations of Islam in his words, teachings, and actions are generally overlooked. These exoteric and esoteric differences between Shī'ah Islam and Sunnī Islam are, however, among the root causes of the qualitatively different politics of Shī‘ah Muslims compared to that of the Sunnīs.

Some scholars have tried to address this deficiency in the literature. Amir-Moezzi, for instance, argues that the early history of Shī'ah Islam was heavily esoteric. ${ }^{182}$ The Shī‘ah Imāms ${ }^{183}$ were viewed by their followers as divinely guided spiritual authorities with supernatural knowledge. They were believed to be the raison d'être of the universe and the channel through which the Divine Grace is bestowed upon man. In this esoteric environment, Shī'ah Muslims perceived themselves as a special community responsible

\footnotetext{
${ }^{181}$ Ibid. p. 39.

182 See Amir-Moezzi, Mohammad A. (1994). The Divine Guide in Early Shi'Ism: The Sources of Esotericism in Islam. Albany: State University of New York Press.

${ }^{183}$ As briefly discussed in Chapter I, these are the twelve descendants of the Prophet who are the supreme religious authorities -along with the Prophet and the Qur'ān- for Twelver Shī'ah Muslims. The first Shī'ah Imām, 'Alī, is often considered as one of the Muslim archetypes of spiritual devotion and esoteric achievements.
} 
for protection of the sacred institution of Wilāyah and Walāyah. ${ }^{184}$ Towards this goal, Taqīyyah $^{185}$ was also seen as the duty of Shī'ah Muslims. It must be mentioned, however, that this self-perception was challenged by a minority group within the Shī'ah community, the proponents of the doctrine of "Ulamā al-Abrār -i.e. "the Pious Scholars." These minority Shī'ah theologians maintained that the Imāms were specially learned and highly pious, yet regular, human beings. ${ }^{186}$ Yet, the majority of Shī‘ah Muslims gradually believed in a special esoteric place of their Imāms in the metaphysical and spiritual hierarchy of the universe. The special status of the Imāms was later on translated to certain theological doctrines including that of the "infallibility" of the Imāms or "Iṣmah. These later theological doctrines have had a less esoteric undertone according to AmirMoezzi. Even though the early Shī'ah esotericism gave way to, in Amir-Moezzi’s words, a "theological-juridical-rational Imamism,"187 it always played an important role in Shī'ah version of Islam. The esotericism accompanied Shī'ah exotericism and, in fact, influenced Sunnī esoteric traditions as well. The strength of esoteric themes in Shī'ah Islam has been such that they have made a powerful and ironic return in modern times within an unusual context of modern Iranian politics. ${ }^{188}$

\footnotetext{
${ }^{184}$ See Chapter V.

${ }^{185}$ As briefly introduced before, the term generally implies caution and prudence in order to protect one's safety or property. See Chapter IV for more detail.

${ }^{186}$ See Kadivar, Mohsen. (2006). Qarā’at Farāmūsh Shudih: Bāzkhān̄̄ Naẓarīyih “"Ulamā Abrār”-Talaqqī Awwalīyih Islām Shī'ī az Aṣl "Imāmat”. Madrisih, 1(3), 92-102.

${ }^{187}$ Amir-Moezzi, Mohammad A. The Divine Guide in Early Shi 'Ism. p. 61.

${ }^{188}$ A brief discussion of the mystical dimensions of modern Iranian politics and the utilization of the Shí ${ }^{-} \overline{1}$ mystical doctrines such as Wilāyah and Walāyah for the institution and maintenance of political power is offered in Chapter V.
} 
At the same time, the exoteric question of justice began to surface partly in response to the Shī'ah community's minority status. Justice is indeed a universal theme in various Muslim political philosophies. Therefore, the question of justice appears in various places in Rosenthal's review of the medieval political philosophies in Sunnī Islam. ${ }^{189}$ The work covers prominent Muslim theologians, jurists, scholars, and philosophers such as al-Fārābī (d. 950 C.E.), Ibn Sīnā (d. 1037 C.E.), al-Māwardī (d. 1058 C.E.), al-Ghazzālī (d. 1111 C.E.), Ibn Rushd (d. 1198 C.E.), Ibn Taymīyah (d. 1328 C.E.) and Ibn Khaldūn (d. 1406 C.E.). A central theme in the book is the relevant discussions in Fiqh, i.e. [Muslim] jurisprudence, which served as the theological foundation for the institution of caliphate. It is important to note that the caliphate is a quintessentially Sunn̄̄ institution and Shī'ah Muslims seldom refer to it. In Sunn̄̄ political philosophies, the institution was deemed necessary for two related reasons. These were to "defend the faith"190 and to "command the faithful."191 A dual system of Mulk-Dīn appeared where the bearers of Mulk, i.e. the rule, should observe and respect religion, or Dīn. The Mulk-Dīn system led to a somewhat "constitutionalist" approach towards the institution of caliphate in which the sovereignty of the caliph was not selfreferential. The notion was further corroborated by a Hadīth, or tradition, of the Prophet that described Dīn, i.e. religion, and Mulk, i.e. political authority, as "twins." While this

\footnotetext{
189 See Rosenthal, Erwin. (1962). Political Thought in Medieval Islam: An Introductory Outline. Cambridge: Cambridge University Press.

${ }^{190}$ Ibid. p. 8.

${ }^{191}$ Ibid. p. 26.
} 
dual system remained at the core of Sunnī political philosophies, ${ }^{192}$ the challenge of reconciliation between reason and Dīn/Sharī'ah remained a primary matter of philosophical speculations among Sunn̄̄ Hukamā', or theosophers. In these speculations, the question of justice often appeared as a secondary concern. Rulers' obligations to promote justice usually followed the central obligation of the sovereign to uphold Sharī'ah. In other cases, the two obligations were deemed as identical: "[ $\mathrm{t}]$ he caliph is the defender of the faith, the dispenser of justice."193 The above pattern shaped Sunn̄̄ political philosophies for the most part of the Medieval Age. ${ }^{194}$

Lambton examines Iranian medieval theories and practices of government especially during the (Sunn̄̄) Saljūq period. ${ }^{195}$ The mainstream Sunnī framework during this period was the theory of imamate. ${ }^{196}$ The theory was manifested in the divinely constituted office of the caliph following the examples of the four "Rightly Guided

192 Ibid. p. 8. This is, according to Rosenthal, parallel to Ibn Khaldūn's distinction between Sīyāsah al'Aqlīyah (the politics of reason or rational politics related to the notion of Mulk above) and Sīyāsah alDīniyah (the politics of religion or religious politics related to the notion of Dīn above).

${ }^{193}$ Ibid. p. 26.

${ }^{194}$ Rosenthal also notes the enduring impact of Plato's Republic on Muslim political philosophy. In fact, Plato's philosopher-king related to the dual functions of the institution of caliphate. Similar to the philosopher-king, the caliph was expected to make normative as well as political decisions and to heed both forces of morality and reason. Al-Fārābi, in particular, developed a Muslim version of Plato's philosopherking in his influential Ārā'a Ahl al-Madīnah al-Fādilah [Al-Fārābi, Abū Nașr (1985). On the Perfect State. USA: Oxford University Press]. Furthermore, Plato's political "idealism" partially shaped the mainstream philosophy of power both in Sunnī Islam and in Shī'ah Islam.

${ }^{195}$ The Saljūq dynasty ruled parts of Persia, the Central Asia, the Levant and today's Turkey from the early eleventh century to the early fourteenth century. See Lambton, Ann K. S. (1980). Theory and Practice in Medieval Persian Government. London: Variorum Reprints.

196 The word comes from the same root as the Arabic word Imām does. However, imamate here has a different connotation compared to the same notion in Shī`ah Islam. In Sunnī terminology, imamate means the headship or leadership of the Muslim Ummah. 
Caliphs" and the Prophet. ${ }^{197}$ Trusted in the institution of imamate was the custodianship of Sharī'ah that rendered the state "Islamic." 198

The crisis and eventual fall of the institution of the caliphate ${ }^{199}$ and the rise of the institution of the sultanate ${ }^{200}$ affected Sunnī political philosophies. The historical transition was reflected in a dual quest to theorize a viable Muslim political structure. The sultanate was to preserve "Islamic" character of the society on the one hand and to maintain its political unity in the face of outside enemies on the other. The sacredness long attributed to the institution of the caliphate, however, made the transition difficult. Some Muslim philosophers strove to -at least theoretically- save the caliphate. They tried to synthesize the institutions of caliphate/imamate and sultanate in one framework. It was an effort to emphasize the continuity of a "sacred" office that went back to the Prophet himself. Nevertheless, many including ibn Taymīyah had to give in to the abolition of the institution of the caliphate. Ibn Taymiyah even accepted the possibility according to religious law of having more than one Imām, i.e. political leader, among Muslims and rejected the religious obligation and necessity to uphold the institution of the caliphate. The accommodation of the reality and the fear of chaos went so far that it

\footnotetext{
${ }^{197}$ The four "Rightly Guided Caliphs" are Abū Bakr, 'Umar ibn al-Khaț̣āb, 'Uthmān ibn 'Affān, and 'Alī whose caliphates extended from 632 C.E. to 661 C.E.

${ }^{198}$ See also Rosenthal, Erwin. Political Thought in Medieval Islam.

${ }^{199}$ The demise of the institution of the caliphate was due to a variety of causes including challenges from within the Muslim world. It was the Mongol invasion, however, and the fall of Baghdad in 1258 C.E. that sealed the fate of the Abbasid caliphate.

${ }^{200}$ It must be mentioned that Ottoman sultans sometimes viewed the institution of sultanate as the continuation of the institution of caliphate. The necessity of having blood relation to the Prophet at the heart of the institution of caliphate, however, created some challenges for the Ottoman sultans' formulation of their political legitimacy as caliphs.
} 
reached an unusual pitch. Al-Khunjī argued that the Imām, i.e. the political leader, was "the bearer of power, whether he was righteous or unrighteous."201 Al-Khunjī's extreme stance has become, rather unduly, a common theme in Shī'si critiques of Sunnī political philosophies ever since; for as a minority, Shī'ah Muslims had developed quite different theories of political legitimacy based on the "righteousness" of the bearer of power.

Lambton then follows the familiar categorization of Muslim theories of government into those developed by Muslim philosophers and influenced by ancient Greek political philosophies and those put forward by Muslim jurists and characterized by the centrality of Sharí ${ }^{-} a{ }^{202}$ In between the two categories lies the so-called "Mirrors for Princes" literature, or Sīyāsat-Nāmih. These medieval pamphlets of recommendations for rulers often include philosophical, moral, practical, and juristic arguments. ${ }^{203}$ In contrast to mainstream Shī'ah political thought, the question of legitimacy of caliphate is largely brushed away in Sunnī theories of state. A common theme was to resort to the necessity of the state for provision of a Sharī'ah-based order. Viewing Shī'ah Islam as a "sect," ${ }^{204}$ Lambton argues that "Shī‘̄̄sm" originally initiated as "simply a political legitimist movement." 205 The author also makes the rather sweeping claim that "[n]o

\footnotetext{
${ }^{201}$ See Lambton, Ann. Theory and Practice in Medieval Persian Government. p. 181.

${ }^{202}$ See Lambton, Ann K.S. (1981). State and Government in Medieval Islam: An Introduction to the Study of Political Theory. Oxford: Oxford University Press.

${ }^{203}$ These numerous pamphlets were written in the same spirit that Machiavelli's Prince seems to have been written in. They often address the questions of power, justice, and how to maintain political authority. At the same time, the notion of political expediency is discussed in some of these "Mirrors for Princes" literature creating an important leeway for the sovereign to justify its actions.
}

${ }^{204}$ Ibid. p. 213.

${ }^{205}$ Ibid. p. 219. 
Muslim political theory of state [...] asks the question why the state exists."206 Yet, she acknowledges that the removal of the Abbasid caliph during the Mongol invasion posed much less of a challenge to Shī'ah Muslims compared to their Sunnī coreligionists. ${ }^{207}$ The easier accommodation of the fall of the caliphate was in fact a result of Shī'ahs' having been more comfortable in questioning the legitimacy and the necessity of the state. One of the earliest theoretical questions that Shī'ah jurists strove to answer was how to deal with what they perceived as a "fundamentally illegitimate political structure.” The perceived illegitimacy was rooted in Shī'si categorization of all political powers during the Occultation ${ }^{208}$ as the illegitimate “usurper" of Imāms' authority. ${ }^{209}$ The Shī'‘̄ stance led to a variety of doctrines including Taqīyyah elaborated and expanded by prominent religious figures such as Shaykh al-Mufid ${ }^{210}$.

\footnotetext{
${ }^{206}$ Ibid. p. 1.

${ }^{207}$ Ibid. p. 224.
}

${ }^{208}$ As briefly discussed before, the Occultation refers to the Shī'i doctrine that asserts the Shī'ah twelfth Imām, Muhammad al-Mahdī, disappeared in 873 C.E. into occultation. From 873 C.E. to this day, Shī'ah Muslims believe, he has lived miraculously and has practiced his Walāyah as a "hidden Imām." He will return, according to Shî'i 1 beliefs, at the end of time ushering in the last stage of human history, which is marked by universal justice and prosperity. For more detail on Shī'i eschatology, see Chapter V. Given the fact that legitimate political authority relates to the notion of Wilāyah and belongs to the Imāms according to Shī'ah Islam, early Shī'ah jurists viewed all other worldly powers as usurpation and, thus, illegitimate. This stance shaped the mainstream political philosophy in Shī'ah Islam until the Iranian Revolution of 1979. The dynamics of Shī'ì doctrine of Occultation within Shī'ah political philosophy became clear to me through my interviews with Professor Mesbahi [M. Mesbahi, Lectures, Spring 2007, and M. Mesbahi, Interviews, Fall 2010].

\footnotetext{
${ }^{209}$ Reviewing the jurisprudential efforts of Shī'ah Muslims to deal with the question of political power, Lambton argues that Imāmīyah -i.e. Shī'ah Muslims- isolated themselves from the reality. According to her judgment, they developed a highly unrealistic political doctrine in which any this-worldly power was deemed illegitimate [see Lambton, Ann K.S. State and Government in Medieval Islam, p. 300].

${ }^{210}$ d. 1022 C.E.
} 
The difficulties and confusions caused by the absence of Imām's authority during the Occultation led to the gradual emergence and prominence of Shī'ah Mujtahīds. ${ }^{211}$ They assumed some of the functions of state in administering the Shī'ah community. The Shī' $\overline{1}$ position vis-à-vis the institution of the caliphate also rendered the question of Zulm, i.e. tyranny, an important theme in Shī'ah political thought. As Lambton notes, Zulm was universally perceived as "the great evil" ${ }^{212}$ by Shī'ah jurists. Lambton also recognizes certain potential paradoxes within Shī'ah political philosophies, which caused some ambiguity in the legitimacy of political power during the (Shī'ah) Safavid period ${ }^{213}$ in Persia as the Shī'ah Shahs and the Shī'ah 'Ulamā ${ }^{214}$ competed with each other in identifying their respective spheres of authority.

Keddie has written a detailed account of Iran's modern history. ${ }^{215}$ The account is built on the long-term interest of Keddie in the dynamics of religion and politics in Iran. The book reviews the uneasy relations between the religious 'Ulamā and the royal court during the Safavid and Qājār ${ }^{216}$ dynasties. She also looks into the evolution of the

\footnotetext{
${ }^{211}$ Mujtahid refers to those Shī'ah religious scholars who have cultivated in themselves the jurisprudential knowledge and the skills necessary for extracting religious laws on single or multiple subject matters.

${ }^{212}$ Ibid. p. 225.

${ }^{213} 1501-1736$ C.E.

${ }^{214}$ The word "Ulamā is the plural for the word "Ālim, which means "possessor of knowledge," and traditionally refers to religious scholars in Muslim world. For an insightful account of the "Ulamā-laity interactions throughout the history of Islam, see Bulliet, Richard W. (1994). Islam: The View from the Edge. New York: Columbia University Press.

${ }^{215}$ See Keddie, Nikki. (2006). Modern Iran: Roots and Results of Revolution. New Haven: Yale University Press.

${ }^{216} 1785$ - 1925 C.E.
} 
financial structure around the offices of the high-ranking 'Ulamā. ${ }^{217}$ The financial structure, in turn, resulted in the independence of 'Ulamā from the state -in contrast to their Sunnī counterparts. The rising power of the 'Ulamā eventually led to their involvements in the Constitutional Revolution ${ }^{218}$ in Persia, the Oil Nationalization movement of 1953, and finally in the Islamic Revolution of 1979 in Iran. While Keddie's book is rich in presenting the relevant historical data, it does not offer an analytical framework to understand the grand dynamics of political thought in Shī'ah Islam.

Such an analytical approach can be found in another work by Keddie where the author investigates the forces of resistance, revolution, and stability in Iranian Shī'ah Islam. $^{219}$ The type of dualism Keddie tries to illustrate, i.e. between revolutionary potential in Shī'ah Islam and the "quietist" necessities of maintaining a stable political structure, is particularly important; for a parallel dualism may be found in $\operatorname{Sh}^{\top}{ }^{‘} \overline{1}$ strategic cultures as well. In fact, a part of this dissertation is to show a similar "idealistpragmatist" dynamic manifested in the doctrines of Shahādah and Taqīyyah. While claiming a "revolutionary nature" 220 in Iranian Islam, Keddie does not explore the theological and doctrinal roots of it. Instead, she emphasizes the institutional privileges, the organizational structure, and the financial independence of the Shī'ah clergy as the

\footnotetext{
${ }^{217}$ This financial structure was developed due to various religious alms paid to elite 'Ulamā. In Shī'ah Islam, these alms included "Khums" -i.e. one-fifth of idled property to be paid annually-, "Zakāt" -i.e. the traditional Muslim alms paid on selected items- and "Waqf" -i.e. religious endowments. To organize the financial transactions between the merchant class and the 'Ulamā, an intricate and ever-growing bazaar'Ulamā network emerged.

$2181905-1907$.

${ }^{219}$ See Keddie, Nikki. (1995). Iran and the Muslim World: Resistance and Revolution. New York: New York University Press.

${ }^{220}$ Ibid. p. 5.
} 
force behind this "revolutionary nature."221 The mainstreaming Ușūlī School of Shī'ah jurisprudence, ${ }^{222}$ Keddie maintains, provided high-ranking Shī'ah 'Ulamā, or the Marāji', with a powerful status. They could now play an active role in matters social and political. The peculiar organization of 'Ulamā and their economic independence, however, was rooted in Shī' $\overline{1}^{-}$strategic discourses on political power as well as the social reality of having been a minority for a long time.

Keddie also investigates the examples of modern "political revival" in the Muslim world. $^{223}$ This wave of "political activism" began to emerge in the past two centuries as a response to colonialism and imperialism. The tobacco "movement," which was the precedent to Persia's Constitutional Revolution, has been of central historical and symbolic importance. Keddie reviews the 1891-2 tobacco boycott in Persia and the central role played by the alleged fatwā -i.e. religious rulings- of a Mujtahid, Grand Ayatollah Shīrāzī. The fatwā created a mass boycott that eventually turned out to be a successful political action. ${ }^{224}$ The boycott is symbolically important for it was among the

\footnotetext{
${ }^{221}$ Related arguments may be found in Keddie, Nikki. (1983). Religion and Politics in Iran: Shi ism from Quietism to Revolution. New Haven: Yale University Press. The book is a useful collection of articles by prominent scholars covering a variety of subjects such as the early developments in the notion of imamate and authority, the Ușūî̀-Akhbārī divide, the qualified openness of the "gates of Ijtihād," the pro-status quo stances of 'Ulamā, the bazaar-'Ulamā interactions, as well as a brief review of the political thoughts of important figures such as Ayatollah Kāshān̄i, 'Alī Sharī‘atī̄, Ayatollah Bāqir Șadr, and Ayatollah Khomeini.
}

${ }^{222}$ The Ușūlī-Akhbārī split is one of the main divisions in the history of Shī'ah jurisprudence. The Ușūlīs generally give a higher status to independent reasoning in religious rulings. In contrast, the Akhbārīs argue for stricter and more literal adherence to religious texts, the traditions of the Prophet, and those of the Shī'ah Imāms. For more discussion, see below and also Nasr, S. H. et al (Eds.). Expectation of the Millennium. pp. 280-6.

${ }^{223}$ See Keddie, Nikki. (1966). Religion and Rebellion in Iran: The Tobacco Protest of 1891-92. London: Frank Cass; Keddie, Nikki. (1968). An Islamic Response to Imperialism: Political and Religious Writings of Sayyid Jamal al-Din "al-Afghani”. Berkeley: University of California Press; and Keddie, Nikki. (1972). Sayyid Jamal al-Din "al-Afghani": A Political Biography. Berkeley: University of California Press.

${ }^{224}$ The alleged fatwa is reported to be issued in 1891 in response to a wide range of concessions given to a 
first times when the power of the 'Ulamā vis-à-vis the state and the colonial powers came to the light. In addition, the success of the boycott led to the rise of the Shī' 1 doctrine of Nafy-i Sabīl -i.e. Refusal of [others'] Way [to dominate Muslims]. ${ }^{225}$ This doctrine encouraged Shī'ah Muslims to remove any way by which non-Muslims might dominate Muslim nations. It also functioned as a religious creed for obtaining “independence."

In a similar context, Keddie traces the influence of Shī‘ 1 doctrines on Jamāl al-Dīn

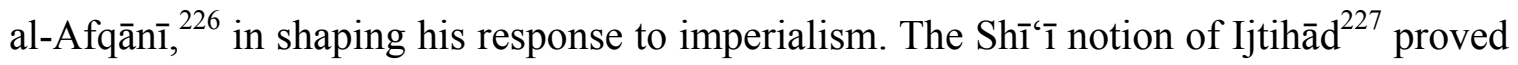
to be essential for al-Afqān̄ though he usually represented himself as a Sunnī Muslim. According to Mesbahi, al-Afqān̄̄'s alleged role in soliciting the famous boycott fatwā in

British citizen, Major Talbot. The concession was granted in 1890 by Nāșir al-Dīn Shah of the Qājār dynasty in order to cover parts of the Persian state's large budget deficit. Included in the concession was a monopoly right for the cultivation, sale, and export of tobacco products. Threatened by the economic prospects of the concessions, the domestic tobacco industry in Persia protested. Eventually, it is reported that Grand Ayatollah Shīrāzī issued a fatwā banning the use of tobacco and emphasizing that observing the ban was a religious duty. The widespread observance of the fatwā forced the Shah to revoke the concession deal with Major Talbot. See Keddie, Nikki. Religion and Rebellion in Iran; and Abrahamian, Ervand. (1982). Iran between Two Revolutions. Princeton: Princeton University Press. p. 73.

${ }^{225}$ The most important religious foundation for this doctrine is the verse 4:141 of the Qur'ān, which states "[...] and never will God grant to the unbelievers a way (to triumph) over the believers" [consulted with Yūsuf 'Alī's translation]. This doctrine was officially adopted into Iran's Constitution after the Revolution of 1979 [see The Constitution of Islamic Republic of Iran, Articles 152 and 153].

${ }^{226}$ Also known as Jamāl al-Din Asadābādī, al-Afqānī (d. 1897 C.E.) was arguably one of the major figures in the Muslim political revival in the nineteenth century. Although he did have some religious education, the extent of this education is not known. Al-Afqāni travelled extensively throughout the Muslim world and resided in various places including Egypt, Persia, and Turkic Ottoman Empire as well as Europe. A "political activist" interested in strategic alliance among various Muslim powers against imperialism, alAfqānī influenced the next generation of Muslim "revivalists" such as the Egyptian jurist, Muhammad 'Abuh (d. 1905). See Keddie, Nikki. An Islamic Response to Imperialism; and Keddie, N. Sayyid Jamal alDin "al-Afghani."

${ }^{227}$ Ijtihād means the systematic extraction of new religious rules from authentic sources and via legitimate methods by a Mujtahid. It has been defined as the "process of arriving at judgements on points of religious law using reason and the [science] of principles of jurisprudence" [see Subhān̄ī, Ja 'far. (2001). Doctrines of Shi 'i Islam: A Compendium of Imami Beliefs and Practices. Trans. By Reza Shah Kazemi. London: I.B.Tauris. p. 182]. 
the tobacco "movement" illustrates his capacity to think strategically. ${ }^{228}$ Al-Afqān̄ managed, in other words, to employ the dormant power of the Shī'ah 'Ulamā to advance his political agenda. Meanwhile, one may find the trace of the quintessentially $\operatorname{Sh}^{\top} \overline{1}^{\top} \overline{1}$ doctrine of Taqīyyah in his life ${ }^{229}$; for al-Afqānī proved to be a versatile man who had an incredible level of flexibility and prudence in accommodating different settings both within and without the Muslim world. In fact, al-Afqān̄i is, according to Keddie, one of the first Muslims in modern times who practiced the strategy of Taqìyah not only as a survival strategy but also as a means to exert political influence. This is why scholars such as Mesbahi believe al-Afqānī to be historically an important Shī'ah strategist. ${ }^{230}$

The notion of Ijtihād and the doctrine of Taqīyyah illustrate some of the strategic potential of Shī'ah Islam. It also reminds the relevance of theology in shaping social phenomena. The rather "essentialist" Identity approach embedded in the "Orientalist" literature sometimes makes it difficult to analyze such strategic potential of theology. Without taking into account the role of religious ideas in shaping Shī'ah history, including ideas about political power, justice, and security, it is not possible to understand why, for instance, modern Iran has had such an active political dynamics in the past century including the Constitutional Revolution of 1905, the Nationalization of Oil movement of 1953, the "White Revolution" of 1963, the Islamic Revolution of 1979, the

\footnotetext{
${ }^{228}$ M. Mesbahi, Lectures, Spring 2007.

${ }^{229}$ See Keddie, Nikki. An Islamic Response to Imperialism. pp. 18-9.

${ }^{230}$ M. Mesbahi, Lectures, Spring 2007.
} 
Iran-Iraq war in the 1980s, the Reformist movement in the 1990s, the rise of Iranian neoconservatives in the $2000 \mathrm{~s}$, and the recent "Green movement" of $2009 .^{231}$

Amir-Arjomand offers an informative examination of Shī'ah history. ${ }^{232}$ During the period in which the Shī'ah Imāms were present ${ }^{233}$, Amir-Arjomand notices certain periods of "political quietism" by the Imāms. ${ }^{234}$ The rather long periods of "political quietism," in turn, provided a strong religious justification for acquiescence of Shī'ah Muslims to non-Shī'ah rulers. During the "major Occultation," or al-Ghaybah al-Kubrā, with the important exceptions of some Shī'ah rebellions, "political quietism" became the Shī'ah modus vivendi. The "quietism" was also an expedient strategy that contributed to the survival of Twelver Shī'ah Muslims. Amir-Arjomand views the doctrine of Taqīyyah as an indication of de-politicization of Shī'ah Islam due to the prevailing social realities. By paying attention to Shī's̄ tradition of "political quietism," Amir-Arjomand tries to

${ }^{231}$ The relatively quiet period in Iran's modern history between the Constitutional Revolution in 1905 and the Nationalization of Oil movement in 1953 was due, in part, to the international context of this period. As Keddie notes, this international context of Iranian politics included the two World Wars and the extensive and aggressive involvement of Russian and British governments in Iranian affairs. In terms of domestic politics, foreign powers' interventions were among the most important determining factors in this period. In addition to this international context, the transition in 1926 from the Qājār dynasty to the Pahlavī dynasty (1925 - 1979) in between the two World Wars played a role in the containment of anti-status quo social forces in Iran. See Keddie, Nikki. (1980). Iran: Religion, Politics and Society: Collected Essays. New York: Frank Cass.

${ }^{232}$ See Amir-Arjomand, Said. (1984). The Shadow of God and the Hidden Imam: Religion, Political Order, and Societal Change in Shi 'Ite Iran from the Beginning to 1890. Chicago: University of Chicago Press.

${ }^{233}$ This period extends from 632 to 941 C.E. according to Shī'i beliefs. The period from 874 to 941 C.E. is called the period of "minor Occultation." Shī'ah Muslims believe that during this period, the twelfth Imām, Muhammad al-Mahdī, remained in contact with his followers through four representatives. These included 'Uthmān ibn Sa'īd (d. 875-6 C.E.), Muḥammad ibn 'Uthmān (d. 917-8 C.E.), Ḥusayn ibn Rūh Nawbakhtī (d. 937-8 C.E.), and "Alī ibn Muhammad Samurī (d. 941 C.E.). Shortly before the death of the last representative in 941 C.E., it is believed that al-Mahdī announced the beginning of his "major Occultation" lasting till this day and ending at the end of history.

${ }^{234}$ This "political quietism" was particularly noticeable during the imamate of the fourth, the fifth, the sixth, the ninth, the tenth, and the eleventh Shī'ah Imāms. See Chapter IV for more discussion. 
balance Keddie's argument regarding revolutionary potential in Shī'ah Islam. ${ }^{235}$ It is with the combination of the two traditions that one may explain as distinct political actors as Ayatollah Khomeini and Ayatollah Sīstānī ${ }^{236}$ within the same analytical framework.

In terms of historical developments, the Shī' ${ }^{1}$ Safavid dynasty rose from the more "activist" tradition in Shī'ah Islam. ${ }^{237}$ Within the increasingly successful Safavid political system, a mutually beneficial arrangement emerged between the Safavid royal court on the one hand and the Shī'ah 'Ulamā on the other. The amicable relations began with the declaration of Shī'ah Islam as the religion of the state in Persia in 1501 C.E. by Shāh Ismā‘̄il $I^{238}$. The Iranian Shī`ah Islam was further strengthened by the migration of a group of elite Shī'ah Fuqahă $\overline{ }^{239}$ from the Jabal al-'Āmil region in Ottoman Syria ${ }^{240}$ to

${ }^{235}$ It seems, however, that Amir-Arjomand interprets "political quietism" of Shī'ah Muslims as an indication of secularization of Shī ah Islam. This is not an unproblematic interpretation for it is inconsistent with the later developments in Shī'ah history. The extent of Sh'̄'ah "political activism," especially in the modern era, shows that secularization never really took roots among Shī'ah Muslims. This, indeed, does not mean dismissing the practical and political significance of "quietism" in Shī'ah Islam and its consequences. Eventually, however, the loose separation of political and religious authorities during the Safavid and the Qājār periods proved to be unsustainable as the institution of monarchy gradually lost its power and the institution of 'Ulamā gradually increased its influence.

${ }^{236}$ Ayatollah Sīstānī (b. 1930) is the current Za‘'̄m, or Head, of the Sh'̄'ah seminary in Najaf, Iraq. His approach towards politics appears to be close to cautious "pragmatism" or "quietism" of the traditional Shī'ah 'Ulamā.

${ }^{237}$ It is important to acknowledge the Sunnī Sufi roots of the Safavid dynasty in addition to its Shī'ī ones. In fact, some scholars have suggested that the adoption of Shi'a Islam as the religion of the new-born Safavid state might have had something to do with the political calculations vis-à-vis the Sunni Ottomans [see for instance Abisaab, Rula Jurdi. (1994). The Ulama of Jabal 'Amil in Safavid Iran, 1501-1736: Marginality, Migration and Social Change. Iranian Studies, 27(1-4), 103-22]. Despite these alleged political calculations, one cannot ignore the strong religious reverence, if not adherence, of the founders of the Safavid dynasty towards Shī'ah Islam.

${ }^{238}$ d. 1524 C.E.

${ }^{239}$ The word Fuqahā is the plural for the word Faqīh, which means jurist or the scholar of jurisprudence.

${ }^{240} \mathrm{Jabal}$ al-'Āmil is a mountainous region located in today's Lebanon; for centuries the region had been a Shī'ah enclave. When the Safavid rose to power in Persia, they needed a strong theological and intellectual articulation of their political legitimacy vis-à-vis the well-established institution of the sultanate in Ottoman 
Persia. ${ }^{241}$ The long list of the 'Āmilī 'Ulamā in Safavid Persia include some very prominent Shī'ah theologians, philosophers, and Mujtahids such as Muhaqqiq al-Karakī also known as Muhaqqiq al-Thānī (d. 1533 C.E.), Zayn al-Dīn al-'Āmilī also known as Shahīd al-Thānī (d. 1558 C.E.), Shaykh al-Bahā’̄ì (d. 1621 C.E.), Mīr Dāmād (d. 1631-2 C.E.), and Muhammad al-Ḥurr al-'Āmilī (d. 1692 C.E.).

Amir-Arjomand believes that the complex Safavid system led to the separation of the realm of religion from that of politics. ${ }^{242}$ The assumption of total separation of politics and religion is, however, problematic. Muhaqqiq al-Karakī, for instance, obtained special privileges during the reign of Shāh Ṭahmāsp. His religious authority and Shāh Ṭahmāsp's obedient reverence towards him was often translated to political influence. Muhaqqiq al-Karak̄ was granted the title of "Mujtahid al-Zamān̄̄"243 referring to his status as the Mujtahid who represented the hidden Shī'ah Imām, Muhammad al-Mahdī, at the time. The official title survived after Muhaqqiq al-Karakī and was given to prominent Shī'ah 'Ulamā throughout the Safavid period. The office of Mujtahid al-Zamānī signified

Empire. Formulated as the continuation of the sacred institution of the caliphate, the Ottoman sultanate posed a major legitimacy challenge to the young Safavid rule. To address this challenge, the Safavid found in Jabal al-'Āmil the much-needed Shī'i intellectual powerhouse. It must be mentioned that the emergence of Jabal al- 'Āmil as a prominent center of Shī'ah education was in part due to the relative demise of Hullih, the traditional center of Shī'ah 'Ulamā in Iraq. Therefore, the Safavid court invited the high-ranking Shī'ah 'Ulamā of the remote Jabal al-'Āmil to migrate to Persia's capital city of Isfahan. Many of these 'Ulamā accepted the invitation. As a result, a major center of Shī'ah scholarship and intellectual production emerged in Safavid Persia during the reigns of Shāh Ismā‘īl I, Shāh Ṭahmāsp (d. 1576 C.E.), and Shāh 'Abbās I (d. 1629 C.E.).

${ }^{241}$ See for instance Abisaab, Rula Jurdi. (2004). Converting Persia: Religion and Power in Safavid Empire. New York: I.B.Tauris \& Co Ltd.

${ }^{242}$ Amir-Arjomand, Said. The Shadow of God and the Hidden Imam.

${ }^{243}$ It has been argued that the title of Mujtahid al-Zamānī is the Safavid equivalent of modern title of Grand Ayatollah. Given the association of Mujtahid al-Zamānī with the highest religious office in the Safavid court, however, this does not seem to be the case for, unlike Grand Ayatollah, the title of Mujtahid alZamānī often signified a single highest-ranking religious authority. 
the political legitimacy of the Safavid Shahs through their projected association with the hidden Imām, i.e. the ultimate source of political legitimacy in Shī'ah Islam.

While the assumption of a complete separation of politics and religion is questionable, the Safavid system did provide the religious authorities with a breathing space to flourish. They now benefited from the political and financial support of an increasingly powerful state. In a matter of decades Sunnī Persia turned Shī'ah and arguably the most powerful Shī'ah state in history was born. In parallel, an increasingly influential class of Shī'ah 'Ulamā with complex institutions emerged. After a relatively short period of marginalization under Nādir Shāh (d. 1747 C.E.) of the Afshār dynasty ${ }^{244}$ and during the short-lived Zand dynasty ${ }^{245}$, the Shī'ah 'Ulamā regained their legitimizing power with the rise of the Qājār dynasty in 1785 C.E. At the same time, while the court'Ulamā relations retained certain financial dimensions, the latter gradually established its relative financial independence from the former.

During the same period of Shī'ah history the Ușūli School of thought gained the upper hand in their competition with the Akhbārīs. While the difference between the two theological strands of $\mathrm{Sh}^{-}{ }^{-}$ah Islam cannot be said to be a clear-cut one, there are certain and potentially consequential distinctions. The Ușūlīs grant, in general, a higher status to independent reasoning in religious rulings. They advocate Ijtihād as a systematic use of human reasoning faculty in studying authentic religious sources in order to issue fatwās to address new questions and challenges. In contrast, the Akhbārīs protested what they

\footnotetext{
${ }^{244} 1736-1796$ C.E.

2451750 - 1794 C.E. Note that neither the Afshār dynasty nor the Zand dynasty succeeded in claiming the whole Persian territory leading to the overlap of their reigns over different parts of Persia.
} 
believed to be an unacceptable intervention of human understanding in modifying “eternal and sacred laws" of God. The Akhbārīs obtained some momentum in the early Safavid period as a result of the teaching of Muhammad Amīn al-Astarābādī (d. 1627 C.E.). Al-Astarābādī severely criticized the mainly Ușūlī Shī'ah 'Ulamā of the past. ${ }^{246} \mathrm{He}$ preached stricter and more literal adherence to the traditions of the Prophet and those of the Shī'ah Imāms. The Akhbārīs did not approve of Ijtihād and gave a minimum role to reasoning.

In contrast, the Ușūlīs believed in an ever-expanding role of Ijtihād. The increasing importance of Ijtihād also meant that Fuqahā were to play yet more significant role in Shī'ah society. It was the Fuqahā who were believed to be equipped with the necessary knowledge and skills to use their reasoning in extraction of new religious laws. They developed an elaborate Science of Principles -i.e. 'Ilm al-Ușūl- to guide jurists in systematic generation of new bodies of Shī'si laws. They also created the institution of Marja ‘īyah during the Qājār period. A Marja‘ was a qualified Faqīh who had mastered the Science of Principles and had obtained a firm grasp of Shī'ah religious sources, including the Qur'ān, the traditions and Hadīth of the Prophet, and those of the Shī'ah Imāms. A Marja' was allowed to extract new laws for his followers and the Shī'ah community

\footnotetext{
${ }^{246}$ The noticeable majority of prominent Shī'ah 'Ulamā have been Ușūīi. The list include influential figures such as Shaykh al-Mufĩd, Shaykh al-Ṭūsī also known as Shaykh al-Ṭā'ifah (d. 1068 C.E.), Muhaqqiq Hillī (d. 1277 C.E.), 'Allāmeh Ḥillī (d. 1325 C.E.), Muḥaqqiq al-Karakī, Shahīd al-Thān̄̄, Ja'far Kāshif al-Ghițā' also known as Shaykh al-Akbar (d. 1813), Shaykh al-Anșārī (d. 1864 C.E.), Ākhūnd Khurāsānī (d. 1911), and 'Allāmeh Nā'īnī (d. 1936). Prominent Akhbārī 'Ulamā included Muhammad Amīn al-Astarābādī, Mullā Muḥsin Fiỵ̣ Kāshānī (d. 1680 C.E.), 'Allāmeh Majlisī (d. 1699/1700 C.E.), and Muhammad al-Ḥurr al-'Āmilī. It must be re-emphasized, however, that the categorization is for analytical purposes and not a strict one. For instance, 'Allāmeh Majlisī may be considered as a moderate Akhbārī as he was also under the influence of some tenets of the Ușūlī School of jurisprudence. See Nasr, S. H. et al (Eds.). Expectation of the Millennium. pp. 280-6 for more discussion of Ușūīi-Akhbārī divide.
} 
could direct their religious questions to him. Marāji ${ }^{247}$ became sources to be followed as well as points of reference for the community. This was a consequential transformation in Shī'ah history as it further institutionalized the authority of the Shī'ah 'Ulamā in their relations to the laity. Indeed, the development was not possible without the rise of the Ușūlīs for the Akhbārīs rejected the institution of Marja‘īyah altogether.

Amir-Arjomand's other contribution covers the next centuries of Shī'ah history in Iran up to the Islamic Revolution of $1979 .{ }^{248}$ The more extensive and forceful efforts to marginalize the 'Ulamā in social, educational, juridical, and political matters began under the Pahlavī dynasty. In particular, Amir-Arjomand investigates the causes of the Revolution. The hypothesis about the relative secularization of Shī'ah Islam suggested in his previous works, however, leads him to dismiss the powerful non-“quietist" dynamics of Shī'ah Islam. Amir-Arjomand emphasizes the "success" of the Shah's modernization project. At the same time, he notices that Khomeini's Revolution was a watershed in political philosophy of Shī'ah Islam in terms of theorizing and implementing a "legitimate state" during the "Occultation of the Twelfth Imām" -or fi 'așr al-ghaybah. ${ }^{249}$

${ }^{247}$ The word Marāji` is the plural for the word Marja‘.

${ }^{248}$ See Amir-Arjomand, Said. (1988). The Turban for the Crown: The Islamic Revolution in Iran. Oxford: Oxford University Press.

249 Another informative collection of articles is Amir-Arjomand, Said. (1988). Authority and Political Culture in Shi 'ism. Albany: State University of New York Press. This is an edited volume in which the essays by the editor and by Etan Kohlberg are particularly of interest, although not all the arguments are beyond debate. One point in case is Amir-Arjomand's assumption - presented in his other works too- that Ayatollah Khomeini illustrates a revolutionary departure from Shī'ah tradition of political philosophy. This is in line with Amir-Arjomand's assertion about the relatively successful secularization of Shī'ah Islam during the Safavid and the Qājār periods. While it is true that Ayatollah Khomeini articulated a major change in Shī'ah political theology and especially in the scope of Wilāyat Faqīh, one can argue that he merely used traditional Shī'ī concepts and doctrines such as Ijtihād, Wilāyah, and Walāyah in unprecedented ways [see Chapter V for more discussion of Wilāyah and Walāyah]. Therefore, the tradition Amir-Arjomand is referring to might be, as Shī'ahs sometimes use this analogy, the Husaynī, i.e. the "activist" or revolutionary, tradition in contrast to the Hasanī, i.e. the "quietest," tradition of Shī'ah Islam. 
For the first time, the Ușūlī notion that Shī'ah 'Ulamā can succeed the Shī'ah Imāms in certain capacities was taken to its logical extreme. Khomeini argued that Shī'ah 'Ulamā are not only the religious authority in the absence of the Imāms, but also a legitimate political authority. $^{250}$

Hairi has written a historical account of the consequential era of the Constitutional Revolution from 1905 to $1911 .^{251}$ It reviews the intellectual origins of the Revolution and the role played by the "Ulamā for or against "Constitutionalism" -then perceived as a modern template for political structure of the state. The book also includes a review of the foundations of Shī'ah political theology such as the issue of the succession to the Prophet, the "infallible" Imāms - or the doctrine of "Ișmah-, the Occultation and the institution of Marja‘iyah. ${ }^{252}$ As noted before, The Constitutional Revolution was an important prelude to the Islamic Revolution of 1979. It also surfaced some of the difficulties $\mathrm{Sh}^{\bar{\imath}}$ ah theologians had to tackle when it came to engagement in modern politics. The split among the 'Ulamā in response to the Constitutional Revolution was exemplified in the pro-Constitution Akhūnd Khurāsānī ${ }^{253}$ (d. 1911) in Najaf and pro-

\footnotetext{
${ }^{250}$ For a primary source on Ayatollah Khomeini, see Algar, Hamid. (1981). Islam and Revolution: Writings and Declarations of Imam Khomeini (1941-1980). Berkeley: Mizan Press.
}

${ }^{251}$ See Hairi, Abdul Hadi. (1977). Shiism and Constitutionalism in Iran: A Study of the Role Played by the Persian Residents of Iraq in Iranian Politics. Leiden: Brill.

${ }^{252}$ As mentioned before, the institution of Marja'iyah - or "Marja' al-Taqlīd," i.e. the "Source to be Followed," - is a rather recent development that gained prominence during the Qājār period. The establishment of the office is sometimes attributed to Shaykh Muhammad Husayn Najafi in 1846 C.E. [see Faghfoory, Mohammad H. Ethic of War and Peace in Shi'ite Islam]. During the Safavid period, however, the high-rank 'Ulamā were called "Nuwwāb Imām," which is plural for "Nā'ib Imām" meaning Imām's vicegerent. The idea of "Ulamā being the vicegerent of the Imāms was popularized in particular by Muhaqqiq al-Karakī. He also put this notion in practice by leading the Friday Prayer, a religious role previously believed to be exclusive to the Shī'ah Imāms.

${ }^{253}$ Akhūnd Khurāsān̄̄ is one of the most influential Shī'ah 'Ulamā of modern times. His contributions to 'Ilm al-Ușūl, i.e. the Science of Principles, has been monumental as his works are among the standard 
monarchy Shaykh Faẓlullāh Nūrīist in Tehran. Hairi reviews Tanbīh al-Ummah wa Tanzīh al-Millah written by 'Allāmih Nā'īnī (d. 1936), one of the prominent students of Akhūnd Khurāsān̄i. The book is arguably the most important religious text of the era dealing with the issue of political power in Shī'ah Islam. 'Allāmih Nā'̄n̄ñ acknowledges the limitations of the constitutional system, including "its parliamentary political structure," compared to the ideal Shī'ah political structure, i.e. a system in which the political power is in the hand of the "infallible" Shī'ah Imām. 'Allāmih Nā'̄̄n̄ makes his case mostly based on Shī' $\overline{1}$ theological arguments but also by some borrowings from antityranny literature of the period. He refuted Shaykh Fazlullāh Nūrī’s pro-monarchy stance. Nevertheless, even 'Allāmih Nā'īn̄i maintains the Mujtahids’s right to "veto" any "antiIslamic" legislation. Hairi concludes that while Shaykh Faẓlullāh Nūrī "understood that constitutionalism cannot be brought into conformity with Islam," 'Allāmih Nā'īnī was "confused with wrong or vague interpretations of modern concepts ... [such as] the meaning of liberty and equality in democracy.",255

It is true that Shaykh Faẓlullāh Nūrî̀s opposition to the establishment of the Parliament in Persia after the Constitutional Revolution was partly related to the paradox of sovereignty and self-referentiality of modern nation-states in Shī'ah Islam. ${ }^{256}$ Yet, the

textbooks in various $S^{\prime} \bar{\imath}^{`}$ ah seminaries today. Akhūnd Khurāsān̄̄ also played a significant political role in the Constitutional Revolution. By sanctioning the Revolution, he protected the "Constitutionalists" against being labeled as non-Muslims. His contributions to Shī'ah political philosophy, however, remain understudied. One of the recent studies to address this deficiency has been produced by Mohesn Kadivar in Farsi [see Kadivar, Mohsen. (2007). Sìyāsat-Nāmih Khurāsānī. Tehran: Kawīr Publications].

\footnotetext{
${ }^{254}$ Shaykh Faẓlullāh Nūrī was executed in 1909 by the verdict of a pro-Revolution court presided over by another Shī'ah clergy.

${ }^{255}$ Hairi, Abdul Hadi. Shiism and Constitutionalism in Iran. p. 234.

${ }^{256}$ M. Mesbahi, Lectures, Fall 2007, and M. Mesbahi, Interviews, Fall 2011.
} 
"confusion" mentioned above was universal as both Shaykh Faẓlullāh Nūrī and 'Allāmih Nà'înī had to deal with similar theoretical challenges. The confusion later on manifested itself in the fact that, in 1979, Ayatollah Khomeini implemented some of 'Allāmih Nā'in̄ì's ideas, such as the veto power of a council of Mujtahids, and adopted a similar anti-tyranny $^{257}$ tone. Yet, it was Shaykh Faẓlullāh Nūrī who became the iconic figure among the revolutionaries after the Islamic Revolution. He was praised by Ayatollah Khomeini $^{258}$ despite the fact that Shaykh Faẓlullāh Nūrī had been adamantly against the idea of parliamentary legislation or women's suffrage. Both of these were endorsed by Ayatollah Khomeini. Unlike Khomeini, Shaykh Faẓlullāh Nūrī was also a prominent promonarchy figure. This indicates Ayatollah Khomeini's hovering between "pro-modern" ideas of 'Allāmih Nā'īnī -in his endorsement of the partial sovereignty of the Parliament- on the one hand and the "anti-modern" position of Shaykh Fazlullāh Nūrī in his rejection of certain "non-Islamic" aspects of modern states on the other.

The theoretical difficulties of modern politics for Shī'ah 'Ulamā, therefore, cannot be easily reduced to conclusions such as "incompatibility" or "compatibility" of Islam and modern nation-state. Instead, the complex dynamics that such theoretical and theological challenges have put in motion must be recognized; for there is no single or simple "Shi'i theory of government" 259 as Hairi suggests.

\footnotetext{
${ }^{257}$ A rather common term to refer to the notion of "political tyranny" in modern political discourses of Shī'ah 'Ulamā has been the term Istibdād.

${ }^{258}$ This must be added, however, that Ayatollah Khomeini's praises for Shaykh Faẓlullāh Nūrī mostly occurred before the Revolution of 1979 and in the early years after the Revolution. It has been suggested that as Ayatollah Khomeini struggled with the practical requirements of statecraft, he distanced himself from arguably uncomplicated political ideas of Shaykh Faẓlullāh Nūrī [M. Mesbahi, Lectures, Fall 2007, and M. Mesbahi, Interviews, Fall 2011].

${ }^{259}$ Hairi, Abdul Hadi. Shiism and Constitutionalism in Iran. p. 55.
} 
Hamid Enayat's Modern Islamic Political Thought is one of the most important contributions to the study of modern political thought in the Muslim world. The book includes two sections particularity relevant to this research, namely a brief discussion of the doctrine of Taqīyyah and a more extended discussion of the doctrine of Shahādah in Shī'ah Islam. The basic definition, history, and modern revisions of the two concepts have been briefly explained. Enayat views the martyrdom of Husayn as a powerful and dramatic experience with potential rhetorical power for modern Shî‘'i politics. The event, furthermore, should be contextualized in the central paradigm of justice in Shī'ah Islam. Such an approach would allow to understand the enduring legacy of the massacre of Karbalā in reshaping the notion of Jihād in Shī'ah Islam compared to the same notion in Sunnī Islam. ${ }^{260}$ The resulting Shī̄ì doctrine of Shahādah and Jihād enabled, for instance, the Iranian state to successfully brand its war with the neighboring Muslim country, Iraq, as Jihād without denying the Muslim-hood of the Iraqi nation. This was in contrast to Iraqi state's nationalistic propaganda against Iranian “Ajams."261 In addition to the discussion of Shahādah, Enayat discusses the doctrine of Taqīyyah within his study of political theory in Shī‘ah Islam. Even though the section dedicated to Taqīyyah is a short one, it provides a foundation for the study of the doctrine in Shī's strategic cultures here. This is why in Chapter IV of this dissertation, which discusses the doctrine of Taqiyyah, I will start with Enayat's analysis of the subject.

\footnotetext{
${ }^{260}$ In the following Chapter, a more detailed discussion of Shahādah is offered and the differences between the Shī's 1 and Sunnī understandings of the notion of Jihād are also explained.

${ }^{261}$ The word 'Ajam means non-Arab and when used by contemporary Arabic speakers, it sometimes have derogatory connotations.
} 
The inclusion of Shī'ah Islam along with Sunnī Islam in Enayat's book renders it a significant contribution to a literature that has often focused on Sunnī Islam. Enayat makes this important contribution with a refreshing perspective in studying -Shī'ahIslam:

"The distinguishing features of Shī'̄̄sm in relation to Sunnīsm should be sought not only in its fundamental principles, but perhaps more importantly in its ethos, in the tone of historically developed attitudes which have informed and infused the Shī' $\overline{1}$ stance on the controversial issues of Islamic history, society and dogma. [...]. In trying to understand this ethos, one has to deal with 'historical Shī‘̄ism’, namely, a Shī‘īsm which has taken shape in the actual living experience of specific groups of Muslims [...].",262

\section{Dissertation Contributions}

As reviewed above, this dissertation engages three bodies of literature, namely studies of religion in International Relations, studies of Shī'ah Islam in Religious Studies, and studies of strategic cultures in the sub-field of Security Studies in International Relations. Within the first body of literature, the dissertation belongs to the Phenomenological approach, although it also employs some of the Traditionalist insights about Shī'ah Islam. These Traditionalist contributions will be particularly important in Chapter V on the notions of Wilāyah and Walāyah.

\footnotetext{
${ }^{262}$ Enayat, Hamid. Modern Islamic Political Thought. p. 19. It must be mentioned that, in this dissertation, the use of the term Shī'ism, which is usually an "Orientalist" term and which has been used by Professor Enayat, has been generally avoided. Needless to say, the use of the term by Professor Enayat does not mean his work is an example of the contemporary "Orientalist" literature
} 
As for the studies of Shī'ah Islam within Religious Studies, this dissertation avoids contemporary "Orientalist" reductions and simplifications by employing the Phenomenological approach. In particular, it disagrees with the reduction of Shī'ah Islam to a political "cult," a "sect," or an ideology. Instead, it treats Shī'ah Islam as a selfreferential understanding of Islam. In fact, one of the central contributions of this study is to bridge the gap between phenomenological studies of Shī'ah Islam in Religious Studies on the one hand and Security Studies of Shī'ah Islam on the other. While insightful studies of Shī'ah Islam have been conducted in recent decades, most of them have remained within the framework of Religious Studies. It is the intention of this study to bring parts of that knowledge in a systematic fashion and in a familiar language to the students of International Relations. The main audience of this research is, therefore, the scholars of Security Studies in International Relations. More specifically, this dissertation is a direct contribution to the growing body of literature on various strategic cultures. Two points must be re-emphasized in this regard. First, the notion of $\operatorname{Sh}^{-}{ }^{-} \overline{1}$ strategic cultures does not refer to pure paradigms of security. As mentioned above, a Shì'is strategic culture contains some uniquely $\operatorname{Sh}^{-}{ }^{‘} \overline{1}$ elements embedded within a universal culture of security. Secondly, this study of the theological foundations of Shī's strategic cultures is itself a foundational study. In other words, it does not engage and analyze specific manifestations of Shī'si strategic cultures throughout history. Instead, it strives to understand the generic paradigms of such manifestations. Therefore, this study will serve as a framework for future analyses of various $\mathrm{Sh}^{\top}{ }^{‘} \overline{1}$ strategic cultures in different places and times. 
Finally, my study is essentially an extension to the late Professor Hamid Enayat's Modern Islamic Political Thought. In recent decades, there has arguably been some shift of interest from political thought studies towards Strategic Studies when it comes to Shī'ah Islam. This dissertation engages the doctrine of Shahādah, the doctrine of Taqīyyah, and the ontology of Wilāyah and Walāyah with this shift in mind. It engages the doctrine of Shahādah and Aristotelian prudence at the heart of Taqīyyah primarily to understand their strategic implications. It also employs the notions of Wilayyah and Walāyah as key concepts to better understand Shī'ah Islam. In analyzing these various concepts, this dissertation benefits from the studies on Shī'ah political thought. Yet, it keeps its focus on strategic implications of such thought. At the same time, it does so with a phenomenological sensitivity or, in Hamid Enayat's words, with an eye on the "actual living experience ${ }^{263}$ of Shī'ah Muslims.

${ }^{263} \mathrm{Ibid}$. 


\title{
CHAPTER III
}

\section{SHAHĀDAH: METAPHOR OF AN IDEAL}

\section{Introduction}

\author{
On October $10^{\text {th }}$ of the year 680 C.E., ${ }^{264}$ Husayn ibn 'Alī, the grandson of the \\ Prophet Muhammad, ${ }^{265}$ was killed in the Battle of Karbalā in today’s Iraq. Along with \\ him, nearly all of his reportedly seventy male companions were slaughtered and their \\ families were taken as prisoners. Husayn had been on his way to the city of $\mathrm{Ku}_{\mathrm{fah}}{ }^{266}$ to
} allegedly establish his rule. ${ }^{267}$ En route to Kūfah, Husayn and his companions were met

\footnotetext{
${ }^{264}$ The date coincided with Muharram $10^{\text {th }}$ of the year 61 in Muslim calendar. As will be explained, this day has obtained a significant religious symbolism in Shī ${ }^{`}$ ah Islam.
}

${ }^{265}$ At the time, Husayn was the third Shī'ah Imām following his father 'Alī and his brother Hasan ibn 'Alī -i.e. the second Shī'ah Imām also known by his epithet al-Mujtabā (624 - 670 C.E.). The rest of the twelve Shī'ah Imāms are direct descendants of Ḥusayn ibn 'Alī.

${ }^{266}$ Kūfah is located in today's Iraq to the south of Baghdad. The city was the last capital of 'Alī during his reign as the fourth Muslim caliph -from 656 C.E. to his death in 661 C.E. It was in the great mosque of Küfah that 'Alī was assassinated. In Shī'ah popular culture, the city and its residents at the time often signify those who betrayed the first three Shī'ah Imāms - namely 'Alī, Hasan ibn 'Alī, and Husayn. This betrayal was, according to Shī'ah popular narrative, despite the Kūfis' belief in these Imāms' piety and righteousness as well as their knowledge of the Imāms' political legitimacy.

${ }^{267}$ In the past couple of decades, there have been some discussions regarding Husayn's actual intentions in his politically provocative journey towards the strategic city of Küfah. The mainstream Shī'ah account refers to "thousands of letters" from the Kūfìs inviting Ḥusayn to move to the city and to "reclaim his right to the caliphate" [see "Allāmih Majlisī, Bihar al-Anwār, Vol. 44, p. 376; Aḥmad ibn A 'tham al-Kūfì, Kitāb al-Futūh, Vol. 5, pp. 27-31; Shaykh al-Mufìd, al-Irshäd, Vol. 2, p. 36; and Sayyid Muhṣin al-Amīn al"Āmilī, A 'yān al-Shī'ah, Vol. 1, pp. 589-90]. Some "revisionist" Shī'ah historiographies, however, have queried such explicit political intentions behind the journey. According to these "revisionist" accounts, Husayn left his hometown of Medina due to an increasing political pressure mounted against him and his followers. They refer to Husayn's escape to Mecca to take refuge in the "Holy City" from caliph Yazīd ibn Mu'āwiyah's persecution; and they notice that Husayn left Mecca for Küfah only after he realized that Yazīd ibn Mu'âwīyah would not observe the traditional Muslim belief in the sanctity of the city of Mecca [see Aḥmad ibn Abī Ya'qūb, Tārīkh Ya'qūbì, Vol. 2, pp. 241-2]. In fact, it seems that Husayn himself was not optimistic that the Küfīs would honor their invitations. This is probably why some of Husayn's companions suggested withdrawing into inaccessible mountains of Yemen. Feirahi argues that Husayn, who had expected an eventual military engagement with the army of Yazīd ibn Mu'āwīyah, preferred the geostrategic region of Iraq, which was at the heart of the Muslim world, to the distant mountains of Yemen [see Feirahi, Davoud. Tārīkh Tahawwūl Duwlat dar Isläm. pp. 228-9]. Those who believe that Husayn was forced to leave Mecca for Küfah also refer to a reported sermon he gave once he encountered the first divisions of Yazīd ibn Mu'āwīyah's army. In the sermon, Husayn emphasizes that he -and not Yazīd ibn 
by an army of Yazīd ibn Mu‘āwīyah. Ruling from Damascus, Yaz̄̄d ibn Mu'āwīyah was the self-proclaimed heir to his recently deceased father Mu'āwīyah ibn Abī Sufyān, ${ }^{268}$ the first caliph of the Umayyad dynasty. ${ }^{269}$ Unlike Mu‘āwīyah ibn Abī Sufyān, who had been a master of realpolitik ${ }^{270}$ and a cunning challenger of 'Alī and Hasan ibn 'Alī' ${ }^{271}$, Yazīd ibn $\mathrm{Mu}$ 'āwīyah lacked the necessary political skills and the support network. He also failed to keep at least the appearance of piety and faithfulness that had been associated with the office of the caliph. As a result, Yazīd ibn Mu'āwīyah faced stiff political opposition to his caliphate and had to rely on more brutal measures to establish his rule. In particular, it was necessary for him to extract by force or otherwise a pledge of allegiance from influential figures throughout the Muslim world.

When demanded to offer his pledge of allegiance to Yazīd ibn Mu'āwīyah in Medina, Husayn refused to recognize the legitimacy of the young "extravagant" son of Mu'āwīyah ibn Ab̄̄ Sufyān. The refusal was, of course, only the latest of a long series of tensions between the two families of the 'Alawīs, i.e. the sons of 'Alī, and the Umayyad,

Mu'āwīyah- is the legitimate "bearer of Wilāyah." He then continues that if the enemy does not recognize his Wilāyah, he is ready to "return to Medina" without recognizing Yazīd ibn Mu'āwīyah's caliphate [see Muḥammad ibn Jarīr al-Tabarī, Tārīkh al-Ṭabarī, Vol. 4, p. 303; see also Ibn Kathīr, al-Bidāyah walNihāyah, Vol. 6, pp. 257-60; and Abū al-Hasan Mas'ūdī, Murawwij al-Dhahab wa Ma 'ādin al-Jawhar, Vol. 2]. This offer was rejected leading to Husayn's eventual martyrdom. Despite these recent "revisionist" historiographies of the event, it has been the mainstream narrative of the journey presented above that gave birth to some unique turns in Shī'i strategic cultures. This is why Feirahi argues that the martyrdom of Husayn in Karbalā became the "driving force of all non-Shī'ì (such as Zubayr's) and Shī'ī movements [... that] eventually brought Banī Umayyad [caliphate] down" [see Feirahi, Davoud. Tärīkh Tahawwwül Duwlat dar Isläm. p. 231].

${ }^{268}$ d. 680 C.E.

${ }^{269} 661-750$ C.E.

${ }^{270}$ For some interesting accounts of Mu‘āwīyah ibn Abī Sufyān's political ingenuity and originality, see Feirahi, Davoud. Tärīkh Tahawwwūl Duwlat dar Islām. p. 206.

${ }^{271}$ From this point, wherever the name Ḥasan is used in this dissertation, it refers to Ḥasan ibn 'Alī. 
i.e. the sons of Umayyah. 'Alī himself had fought Mu'āwīyah ibn Abī Sufyān in the inconclusive and controversial Battle of Seffīn ${ }^{272}$. When 'Alī had been elected as the fourth caliph, he had commanded Mu'āwīyah ibn Abī Sufyān, then the governor of the

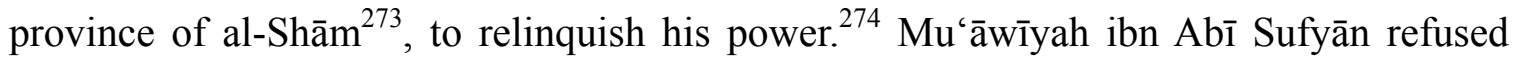
this command and, instead, challenged 'Alī's right to caliphate. He soon became the leader of anti-'Alī political forces and the tension culminated in the Battle of Seffìn. The inconclusive battle led to a period of bifurcated political rule in the Muslim world towards the end of 'Alī's life.

Following the death of 'Alī, his eldest son Hasan assumed the position of caliphate for a short period of time. Only after a military encounter with Hasan and Hasan's concessions to a peace treaty in the face of certain defeat, ${ }^{275} \mathrm{Mu}$ 'āwìyah ibn Abī Sufyān secured his caliphate. The truce, however, did not put to rest the deeper theological and political disagreements between the descendants of the Prophet ${ }^{276}$ on the one hand and the emerging Umayyad court on the other. The Battle of Karbalā, therefore, came in the context of such history of hostility between the sons of 'Alī in Medina and

272657 C.E.

${ }^{273}$ This is today's Syria as well as parts of Lebanon, Jordan, Turkey and Iraq.

${ }^{274}$ The decision of 'Alī to remove Mu'āwīyah ibn Abī Sufyān from his governorship post has often been viewed as an example of the former's lack of interest in "pragmatism" and "political expediency" by Shī'ah Muslims. A more detailed discussion of "Alî's particular political approach can be found in the following Chapter under "Principled Action and Expediency: The Legacy of "Alī."

275 The encounter took place in 661 C.E. near the city of Küfah. According to mainstream Shī'ah historiography, it was the widespread mutiny of the Kūfis in Hasan's army that forced him to withdraw from the battle. Hasan eventually accepted the unfavorable terms of a peace treaty with Mu'āwīyah ibn Abī Sufyān. At the time, Hasan believed that "whatever spares blood is better than whatever causes it be shed" [see Madelung,Wilferd. The Succession to Muhammad. p. 323].

276 'Alī and his sons are often called Ahl al-Bayt by Shī'ah Muslims. The term literally means the "People of the House [of the Prophet]," for 'Alī's first two sons were the Prophet's grandchildren. 
the sons of Umayyah in Damascus.

\title{
The Foundations of Shī‘ī Doctrine of Shahādah and Its Implications
}

\author{
Along with the assassination of ' $\mathrm{Al}^{277}$, the event of the slaughter of the Prophet's
}

grandson in Karbalā brought the notion of Shahādah ${ }^{278}$ to the Shī'ah Muslims' self-

narrative. ${ }^{279}$ The notion of Shahādah had been developed during the life of the Prophet.

The Prophet had engaged in a series of wars against the "infidels." The wars had resulted

in the death of a sizeable number of the Prophet's companions that, in turn, demanded

theological elaboration on their spiritual status and fate. A number of verses ${ }^{280}$ in the ${ }^{277}$ As mentioned before, 'Alī was assassinated in 661 C.E. in Kūfah by a member of Khawārij, a fanatic
and literalist Muslim movement. A brief introduction of this group can be found in Chapter II.

${ }^{278}$ The Arabic word Shahādah comes from the Arabic root sh-h-d (i.e. شهُ ). According to Wehr's ArabicEnglish Dictionary, $s h-h-d$ means, inter alia, "to witness"; "to experience personally"; "to be present"; "to undergo"; "to testify"; "to die as a martyr"; and "to utter the Moslem profession of faith." The root $s h-h-d$ and its derivatives appear more than seventy five times in the Qur'ān. The term has been used in the Qur'ān with a multitude of meanings. Martyrdom is not, however, its primary meaning in the Qur'ān. In Classical Arabic, Shahādah primarily means testimony and bearing witness; and Shahīd means the one who testifies or the one who is the witness [to the truth of some affairs]. Both terms in Arabic have a connotation of truthful testimony based on certitude. The secondary meanings of the terms Shahādah and Shahīd are martyrdom and martyr. In modern times, the secondary meanings of these terms have obtained more significance due to their usage in a number of political paradigms concerning the Muslim world. This is similar to the term Jihād that primarily means exertion and secondarily fighting wars. As for why the term Shahādah has been used in Islam to refer to martyrdom, there have been several explanations. Some have argued that martyrs will "bear witness to the Divine Truth" -or Divine Mercy- on the Day of Judgement [see Muhammad ibn Manzūur, Lisān al- 'Arab]. Others have referred to the Qur'ānic verse that declares martyrs to be alive, "finding their sustenance in the presence of their Lord" [3:169, Yūsuf "Alī's translation]. According to this verse, since martyrs are in fact alive, they are witness to all affairs and, hence, their title is Shahīd. There have also been more esoteric explanations for the Șūfis sometimes call those who achieve the highest level of spiritual ascendance martyrs. This highest level refers to the annihilation of the Șüfi's ego in the Divine Presence and the unification of the former with the latter. Since there is an element of self-sacrifice or annihilation of the self in the Divine Self, the Sūfî literature has used the term Shahādah to describe this state of the soul. Employing this Sūfĩ theme, some have argued that martyrs are called Shahīd in Islam for they bear witness to the highest and most sacred Truth in the world, i.e. the Truth of Unity of all beings. As will be further discussed below, the Șüfĩ themes play an important role in the Shī'ī understandings of Shahādah and the spiritual state of Shahīds.

279 The reader can find a useful summary of Shahādah in Shī'ah political thought in Enayat, Hamid. Modern Islamic Political Thought. pp. 181-94.

280 See, for instance, $2: 154 ; 3: 157,169-171,195 ; 4: 74 ; 9: 111 ; 22: 58 ; 47: 4-6$. Also note that various Prophetic Hadīths reinforced the Muslim notion of martyrdom. See for instance 'Allāmih Majlisī, Biḥ̂âr al- 
Qur'ān, therefore, deal with the notion of Shahādah and the "blissful status" of Shahīds in the eyes of God. Even though this general veneration of Shahādah preexisted the emergence of the Shī'ah-Sunn̄̄ schism, the turn of events in the early history of Islam gave birth to a fairly different doctrine of Shahādah in Shī $^{-}$ah Islam ${ }^{281}$ compared to the dominant Sunnī Islam.

The incident in Karbalā, in particular, showed vividly the grave vulnerability of the Shī'ah community. It led to an acute sense among Shī'ahs of being threatened by fellow Muslims. At the same time, it was seen as evidence that the traditional etiquette of respect and reverence for supposedly inviolable and sacred matters was falling apart in the Muslim society. Even having blood relations to the Prophet and belonging to a family of such high stature could not spare one's life, Shī'ahs deduced. In the honor-driven Arab society of the time, the notion of one's household being imprisoned and exiled was appalling. The fact that such an affront had been committed to the wives and children of Husayn and his companions in Karbalā solidified the belief among early Shī'ah Muslims that they were on their own. In an overwhelmingly Sunnī society and at the dawn of the Muslim empires of the Umayyad and the Abbasid ${ }^{282}$, Shī'ah Muslims were but a weak minority on the fringe. This observation begged for a constant consciousness of their minority status and its implications. It also meant the necessity of elaborating theological

Anwār, Vol. 97, pp.1-16; al-Hurr al-‘Āmilī, Wasā’il al-Shī'ah fi Tahṣ̂̄l al-Masā'il al-Sharī'ah, Vol. 11, pp. 8-10; Muḥammad ibn Ismā'īl al-Bukhārī, al-Ṣaḥ̂h, Vol. 3, pp. 199-235; and 'Alā al-Dīn 'Alī al-Hindī, Kanz al- 'Ummāl fi Sunan al-Aqwāl wal-Af'āl, Vol. 4, pp. 397-407.

${ }^{281}$ See al-Hurr al-‘Āmilī, Wasā’il al-Shī'ah fì Taḥșil al-Masā’il al-Sharī'ah, Vol. 11, p. 8; 'Allāmih Majlisī, Bị̣ār al-Anwār, Vol. 45, p. 118; 'Alī ibn Ab̄̄-Ṭālib, Nahj al-Balāghah, Sermon 119; and Ibid. Letter 53.

282750 - 1258 C.E. 
doctrines as well as survival strategies in order to weather the increasingly harsh environment. It was in this context that Shahādah was re-visited by early Shī‘ah Muslims as a paradigm to take refuge in.

In the face of the utter physical defeat of Husayn in Karbalā and obliteration of nearly all his close companions and the male members of his family, the doctrine of Shahādah was to instill a sense of respect, honor, and even victory. Again, the notion of "victorious martyrdom" had existed in Islam and had been elaborated upon in some verses of the Qur'ān. The story of Husayn, however, brought it to a whole different level. The sufferings that Husayn had to go through in the hands of fellow Muslims began to be understood as the generic story of Shī'ah Muslims. ${ }^{283}$ As a result, some scholars of Islam have argued that in the story of Husayn, Shī'ah Muslims found a mythology for their identity as well as the identity of their enemies. ${ }^{284}$ The fact that the Muslim society silently watched the slaughter of the grandson of the Prophet and, by and large, did not protest it proved to be a wake-up alert for the Shī'ah community. The community had to come in term with its precarious position. To provide itself with a psychological relief from the burden of this overwhelming vulnerability, the early Shī‘ah community developed an elaborate doctrine of sacred suffering and martyrdom. The thrust of this doctrine was the "metaphysical security" 285 of a community so utterly deprived of

\footnotetext{
${ }^{283}$ According to Hamid Enayat, "[t]he memory of Husayn's martyrdom serves as an everlasting exhortation to the Shī'is of all times to brave their numerical inferiority in the face of firmly established majorities" [Enayat, Hamid. Modern Islamic Political Thoughts. p. 20].

284 Soroush, Abdolkarim, Lecture titled “"Aqlānīyat wa Shahādat,” December 15, 2010, Rockville, Maryland. Retrieved from www.drsoroush.com on February 29, 2012.

${ }^{285}$ Shī'ah Muslims commonly refer to the month of Muharram, i.e. the month in which Husayn was killed, as the month of "victory of blood over the sword" to signify this puzzling notion of "metaphysical security." The notion emphasized the eventual and absolute, yet otherworldly, security of the Shi'‘ah
} 
physical security.

Along with this notion of "metaphysical security," there emerged a mainstream Shī' $\overline{1}$ belief that Husayn was well aware of his fate when he embarked on the journey towards Kūfah. He allegedly refused to escape from the battlefield when offered the chance and famously declared hayhāt min al-dhillah, meaning "woe unto the wretchedness." The phrase has ever since become an element of the Shī's discourses on Shahādah, which belittled "wretched survival." Such consciousness regarding the honorable versus the wretched life had of course serious implications for a persecuted minority community. In fact, had it not been accompanied with the more pragmatic doctrine of Taqiyyah ${ }^{286}$, the doctrine of Shahādah could arguably have led to a much more difficult historical trajectory for Shī'ah Muslims.

At the same time, Shahādah provided the early Shī'ah community with the muchneeded source of inspiration and with a sense of honor. The notion of "metaphysical security" asserted Husayn's martyrdom to be for a supreme cause and not in vain, a sacrifice that, according to Shī'ah Muslims, brought him to ultimate security and serenity in the Presence of God. It has been reported that, once encountered with the army of Yazīd ibn Mu'āwīyah, Ḥusayn delivered a sermon. He put forward his grim assessment of the state of the Muslim society in which "the worldly life has been transformed and turned into a more depraved one. [People] have been turning their backs on righteousness and they are doing so as a habit [...]. Do not you see [O my foemen!] that the good has

community in the Divine "grand scheme" and despite the worldly insecurities and persecutions. For more discussion, see Chapter V.

${ }^{286}$ See the following Chapter. 
been forgotten and the evil is not been inhibited? [It is in such conditions that] a believer would rather to meet God [through death]. And, indeed, I do not see this as death so much as salvation, and I do not see living under injustice as anything but misery." ${ }^{287}$ In another famous passage attributed to Husayn, he addresses the motivation behind his journey towards Kūfah. He says 'I have left [Medina] to straighten the affairs of my grandfather's [i.e. the Prophet's] Ummah; I intend to enjoin the good and to prohibit the evil."288 The latter announcement includes a major claim and begs the question of which specific "good" and which specific "evil" Husayn was referring to.

To answer this question, one must note that prior to Yazīd ibn Mu'āwīyah's claim to caliphate, his father, Mu'āwīyah ibn Abī Sufyān, had ruled the Muslim world for about a decade. During this decade, Mu‘āwīyah ibn Abī Sufyān's caliphate remained, for the most part, unchallenged. Husayn, similar to his elder brother, followed a more or less “quietist” approach vis-à-vis Mu‘āwīyah ibn Abī Sufyān. It was only after Yazīd ibn Mu'āwìyah's rise to power that Husayn openly expressed his strongest protests against the "state of affairs" in his "grandfather's Ummah." Husayn goes as far to declare that "it shall be the end of Islam if someone such as Yazīd [ibn Mu'āwīyah] is to be in charge of

\footnotetext{
${ }^{287}$ Various Shī'ah sources have reported longer or shorter versions of the sermon. See 'Allāmih Majlisī, Bihāar al-Anwār, Vol. 44, p. 192; Ibn Shu'bah al-Ḥarrānī, Tuhaf al- 'Uqūl, p. 245; and Sayyid ibn Ṭāwūs, alLuhüf fì Qatlā al-Ṭfüf, p. 48.
}

Note that in many Hadìths attributed to Husayn, one can find a similar theme where he contrasts honorable death in fighting injustice on the one hand and living miserably under injustice on the other. Husayn unequivocally praises the former course while loathing the latter. "Dying honored and free is better," he declares, "than living in humiliation" ['Allāmih Majlisī, Bihăr al-Anwārr, Vol. 44, p. 192; and Shaykh "Abbās al-Qumī, Nafs al-Mahmūm, p. 562] and "death is desired compared to submission to abjection" [Najm al-Dīn Ja'far ibn Namā Hillī, Muthīr al-Aḥzān wa Munīr Subul al-Ashjān, p. 54; and Shaykh alQumī, Nafs al-Mahmūm, p. 562].

${ }^{288}$ See 'Allāmih Majlisīi, Biḥ̄ar al-Anwār, Vol. 44, p. 329. 
the Muslim Ummah."289 The noticeable shift means that the "evil" Husayn was trying to remove from the society was more than political injustice or an "imperfect ruler," for Husayn believed that Mu'āwīyah ibn Abī Sufyān's claim to the caliphate was as unjust as that of Yazīd ibn Mu'āwīyah. Yet, he accepted the former's rule as de facto; and he did not consider it as an "irreversible development" in the Muslims' affairs. The caliphate of Yazīd ibn Mu'āwīyah appeared to be qualitatively different. If left unchallenged by Muslims, Husayn believed, Yazīd ibn Mu‘āwīyah's caliphate would lead to "the end of Islam.”

The key to understanding Husayn's uncompromising opposition to Yazīd ibn Mu'āwīyah is the essentially Shì'ī notions of Wilāyah and Walāyah. As will be further discussed in Chapter V, the two notions constitute a particular Shī‘̄i ontology -a specific understanding of the "metaphysical structure" of the world. Wilāyah and Walāyah refer, respectively, to the exoteric and esoteric aspects of a sacred hierarchy around which the world is believed to have been organized. In Husayn's view, what happened with Yazidd ibn Mu'āwīyah's laying claim on the caliphate was an unacceptable violation of such sacred hierarchies. With his "non-Islamic" outward behaviors and his alleged denial of the Divine Revelations to the Prophet, Yaz̄id ibn Mu'āwīyah epitomized, in Husayn’s eyes, a major deviation in Muslim affairs. In fact, he mentions a number of Yazīd ibn Mu'āwìyah's "blatant" violations on the eve of his martyrdom. He describes Yazīd ibn

\footnotetext{
${ }^{289}$ See Sayyid ibn Ṭāwūs, al-Luhūffí Qatlā al-Ṭfüf, p. 18. Note that in the peace treaty concluded between Ḥasan and Mu'āwīyah ibn Abī Sufyān, there was an item prohibiting Mu'āwīyah ibn Abī Sufyān from creating a hereditary caliphate [see Aḥmad ibn A'tham al-Kūfì. Kitāb al-Futūh. Vol. 4. pp. 290-1; and also Aḥmad ibn Abī Ya'qūb, Tārīkh Ya 'qūbì, Vol. 2, pp. 214-5]. To Ḥusayn, Yazīd ibn Mu'āwīyah's claim to his father's caliphate was, inter alia, a violation of that treaty too. The inherited caliphate was, to Husayn, a clear indication of a return to pre-Islam patterns of tribal politics in the Arabian Peninsula [see Feirahi, Davoud. Tärīkh Tahawwūl Duwlat dar Islām. pp. 201-4].
} 
$\mathrm{Mu}^{\prime} \bar{a}$ wìyah as an "unjust ruler who has turned what is forbidden by God into something allowed; who has broken the Covenant $\left[{ }^{290}\right]$ of God; who is against the tradition of the Prophet; [and] who rules over God's devotees by injustice and arrogance."291 By "straightening the affairs of the Prophet's Ummah," therefore, Husayn intended to reverse such a deviation from Wilāyah and Walāyah. ${ }^{292}$ As such, the more exoteric issue of political injustice seems to have been secondary in Husayn's dramatic and fatal protest against Yazīd ibn Mu'āwīyah.

There is one other indication that short-term political objectives were not a priority in shaping Husayn's decisions. In a number of occasions during his final journey from Medina to Karbalā, it has been reported that Husayn gave permission to and even encouraged his companions to leave; and many of them did so. Had short-term considerations been a factor, Husayn arguably would have not allowed such a large number of desertions. The last of these permissions for leaving came at the last night

\footnotetext{
${ }^{290}$ For the notion of the "Original Covenant" in Islam, see the Qur'ān 7:172 [“When thy Lord drew forth from the Children of Adam -from their loins- their descendants, and made them testify concerning themselves, (saying:) "Am I not your Lord (who cherishes and sustains you)?" They said: "Yea! We do testify." (This) lest ye should say on the Day of Judgment: "Of this we were ignorant."'”]; 36:60 ["Did I not make a Covenant with you, o ye Children of Adam, that ye should not worship Satan?"]; and 33:72 ["We did indeed offer the Trust to the Heavens and the Earth and the Mountains; but they refuse to undertake it, being afraid thereof; but man undertook it; -he was indeed unjust and ignorant" [Yūsuf 'Alī's translation].

${ }^{291}$ Muhammad ibn Jarīr al-Ṭabarī, Tārīkh al-Ṭabarī, Vol. 4, p. 304.

${ }^{292}$ Husayn's assertion that he was the "bearer of Wilāyah and Walāyah" can be recognized in his answer to Walīd ibn "Aqabah, then governor of Medina. After the death of Mu'āwīyah ibn Abī Sufyān, Walīd ibn 'Aqabah approached Husayn to solicit his pledge of allegiance to Yazīd ibn Mu'āwīyah. Refusing Walīd ibn 'Aqabah's request, Husayn says "we [i.e. the Shī'ah Imāms] are the channels of the [Divine] Message; and [we receive] constant visitations from the angles; and [we are] the conduits of the [Divine] Mercy; and with us, God began and to us, He shall conclude... [This is why] a man such as I shall not pledge allegiance to a man such as him [i.e. Yazīd ibn Mu'āwīyah]" [see 'Allāmih Majlisī, Bihar al-Anwār, Vol. 44, p. 325; and Aḥmad ibn A'tham al-Kūfī, Kitāb al-Futūḥ, Vol. 5, p. 14].
} 
before the final day of 'A $\bar{s}$ shürä ${ }^{293}$. In that dramatic night when imminent death was looming over Husayn's camp, he called his men to a meeting. After describing their precarious situation and the prospect of their death, Husayn says "I believe it will be tomorrow when the enemy attacks us. Now, I shall permit you all to leave and I absolve you from your [previous] oath of allegiance [to myself]. So benefit from the darkness of night [to save your lives]! ... For these people are only after me. ${ }^{, 294}$ In this last-night sermon, Husayn also prayed for those who would desert him to be rewarded by God. As a result, Shī‘ah Muslims have often viewed Husayn’s martyrdom as the ultimate and supreme act of individual sacrifice ${ }^{295}$ to protect Islam. The fact that the Imām of the

293 'Āshūrā in Arabic means the number ten or the tenth. The events of Karbalā occurred on the tenth day of the month of Muharram in Muslim calendar. Shì'ah Muslims commonly refer to the day of Husayn's martyrdom as the day of 'Āshūrā; and they generally believe that the Qur'ānic reference to the "ten nights" refer to, inter alia, the first ten nights of Muharram 680 C.E., when Husayn and his small group of companions camped in Karbalā. The promise of heavens for the "peaceful" or "confident soul" at the end of this Qur'ānic chapter has also been believed to be bestowed upon Husayn [see the Qur'ān 89:2, 27-30 and Shaykh Makārim al-Shirāzī, Tafsīr Nimünih, Vol. 26, pp. 440-3. Retrieved from www.andisheqom.com on January 19, 2012].

294 The last-night sermon has been reported in various Shī'ah and Sunnī sources. See for instance Muḥammad ibn Jarīr al-Ṭabarī, Tārīkh al-Ṭabarī, Vol. 4, pp. 317-8; Ibn al-Athīr, al-Kāmil fïl-Tārīkh, Vol. 4, pp. 57-8; Shaykh al-Mufìd, al-Irshād, Vol. 2, p. 91; and Sayyid ibn Țāwūs, al-Luhūf fì Qatlā al-Tufǘf, p. 55 .

${ }^{295}$ The martyrdom of Husayn is the closest equivalent in Islam -within its strict monotheistic frameworkto the Crucifixion of Jesus in Christianity. In both cases, there is a sacrificial element; although in the mainstream Shī'ah story of Husayn, he does not have a Divine nature. In describing Husayn's martyrdom, Shī'ah's sixth Imām, Ja'far ibn Muḥammad, says "[Husayn] offered his blood [to God] to save [God's] devotees from ignorance and confusion" [see "Allämih Majlisī, Bihar al-Anwār, Vol. 98, p. 210; and Muhammad al-Riyshahrī, al- 'Aql wal-Jahl fil-Kitāb wal-Sunnah, p. 163]. Also, in an alleged conversation between Husayn and his step-brother, Muhammad ibn Hanafìyyah, one can find yet another sacrificial imagery. When Muhammad ibn Hanafìyyah tried in vain to dissuade Husayn from embarking on his dangerous journey towards Küfah, Husayn replied that God had wanted to "see him [i.e. Husayn] martyred" [see Sayyid ibn Țāwūs, al-Luhüffì Qatlā al-Tufüf, pp. 39-40]. Although the actual occurrence of this dramatic conversation has been questioned, the imagery has percolated to a great extent into Shī' 1 narration of Husayn's martyrdom.

In addition, similar to the Christian convictions regarding Jesus' Crucifixion, Shī'ah Muslims believe that commemoration of Husayn and mourning for his martyrdom is one of the means towards salvation [see, for instance, 'Allāmih Majlisī, Bihāar al-Anwār , Vol. 44, p. 278; Ibid. Vol. 44, p. 289; al-Hurr al-'Āmilī, Wasā'il al-Shī'ah fì Tahṣīl al-Masā'il al-Sharī'ah, Vol. 14, pp. 500-9; Shaykh 'Abbās al-Qumī, Nafs al-Mahmūm, p. 
whole Shī'ah community viewed the upcoming martyrdom as an individual religious duty and not a collective responsibility of his people had serious strategic implications. It strengthened those theological arguments that viewed the doctrine of Shahādah as an ultimate and exceptional resource. The fact that the deserted companions ${ }^{296}$ had been absolved from their allegiance to the Imām and had been prayed for by the Imām further reinforced this notion. The understanding of Shahādah as an ultimate measure became an important permissive cause for $\mathrm{Sh}^{`}$ 'ah theologians to develop the more pragmatic doctrine of Taqīyyah.

In terms of shaping the strategic paradigm of Shī'ah Islam, the individualistic and non-pragmatic approach of Ḥusayn has had yet another implication. As will be discussed in the following Chapter on Taqīyyah and prudence, on several occasions, the Shī'ah Imāms did appear to be little concerned with "pragmatism." The result was the emergence of a paradigm of "principled action" in Shī'ah Islam along with that of Taqīyyah. Principled action, one might say, is the Shī's equivalent of Kant's deontological- "categorical imperatives." 297 The notion emphasizes acting in accordance to "principles" regardless of the worldly consequences. Two prime examples of adherents to such an approach in the history of Shī'ah Islam have been the first and the third Shī ${ }^{6}$ ah

27; and Enayat, Hamid. Modern Islamic Political Thought. pp. 181-3]. It is interesting to note, however, that Shī'ah Muslims -and the Shī'ah Imāms- have traditionally compared the martyrdom of Husayn with that of John the Baptist [see 'Allāmih Majlisī, Bihār al-Anwā̄r, Vol. 14, p. 168; Ibid. Vol. 14, p. 175; and Shaykh al-Huwayzī, Tafsīr Nür al-Thaqalayn, Vol. 3, p. 324].

${ }^{296}$ It must be noted that those companions who abandoned Husayn have been widely censured by Shí ${ }^{`}$ ah Muslims throughout history. Yet, they have not been considered as non-Shī'ah by the virtue of deserting their Imām due to the explicit permission they had received.

${ }^{297}$ See Kant, Immanuel. (2011). Groundwork for the Metaphysics of Morals: A-German-English Edition. Cambridge: Cambridge University Press. 
Imāms, namely 'Alī and Ḥusayn. While 'Alī’s legacy of principled action in Shī'ah Islam will be discussed in the next Chapter, it is worth looking into this byproduct of Karbalā here. Some of the -mostly earlier-Shī'ah jurists have argued that Husayn was not certain about the outcome of his journey towards Kūfah. These jurists suggest that Husayn left Medina based on rational calculations and with the hope of establishing his political rule against Yazīd ibn Mu'āwīyah in Kūfah. The turn of events, however, forced him to choose between humiliation and death in Karbalā and he, being of such an "honorable lineage," chose the latter. ${ }^{298}$

Mainstream Shī‘ah Fuqahā, in contrast, have believed that Husayn was well aware of his destiny even prior to embarking on his journey towards Kūfah. Either thorough prophecies or by accurate calculations of the political environment, Husayn knew that Küfah would not support his political bid and that he would die. Yet, he did not draw back. This, many Shī'ah commentators have argued, was due to Husayn's adherence to the paradigm of principled action and his low regard for "consequentialism." 299 Some of the later Fuqahā, on the other hand, have tried to combine the two interpretations. While acknowledging Husayn's knowledge of his destiny, these jurists argue that the "Islamic principle" for which Husayn left Medina was, indeed, to establish an "Islamic state" in Kūfah. He knew that he would not succeed. Nonetheless, he embarked, according to these jurists, on his journey towards martyrdom to set a model for his Shī'ah followers. Prominent among the Shī'ah jurists who have

\footnotetext{
${ }^{298}$ See, for instance, Enayat, Hamid. Modern Islamic Political Thoughts pp. 190-4; and Ṣāliḥ̄i Najafābādī, Ni‘matullāh. (1970). Shahīd Jāwìd. Tehran: Unknown.

${ }^{299}$ See 'Allāmih Majlisī, Bih̄ār al-Anwār, Vol. 44, p. 329.
} 
developed this synthetic explanation -or re-elaboration- is Ayatollah Khomeini (d. 1989). ${ }^{300}$ Each of the above three explanations of Husayn's martyrdom have important implications for Shī'ī strategic cultures. The legitimacy of expediency and "pragmatism" as well as the significance of establishing a -Shī' $a h-$ state in Shī'ah Islam all pertain to how Shī'ah Muslims interpret Husayn’s actions. In particular, the interpretation affects the Shī' $\overline{1}$ criteria for engaging in war or opting for peace and for how much such decisions rely on pragmatic or deontological considerations.

It must be re-emphasized that the veneration of Shahādah in Shī'ah Islam and the singular place given to the "Master of the Martyrs" also indicated the special character of Husayn's actions. It is worth noting that out of the twelve Shī'ah Imāms, who are all considered "infallible" by Shī'ah Muslims, it was only Husayn who was killed on the battlefield. By most measures, Husayn's tradition is an exception among the Shī'ah Imāms. The majority, if not all, of the Shī'ah Imāms after Ḥusayn followed a cautious and prudent course of actions. Strategically speaking, this also contributed to the emergence of the notion that Shahādah is a measure to be employed in extraordinary situations. Enayat argues that

"[w]ith the increasing tendency of the Shī'is to a passive form of taqiyyah, and acquiescence in the established order, the concept of the martyrdom of Husayn as vicarious atonement prevailed over its interpretation as a militant assertion of the Shī's causes.

\footnotetext{
${ }^{300}$ See, for instance, Ayatollah Khomeini, Sahīfih Nūr, Vol. 17, pp. 52-61. Retrieved from www.tebyan.net on January 23, 2012.
} 
Concomitantly, weeping, and not edification or political indoctrination, came to be recognised as the sole aim of all reminiscence of Husayn., ${ }^{301}$ (emphases in the text)

The spectacle of Karbalā proved to be a charismatic one for Shī'ah Muslims. It led to annual commemoration of the martyrdom of Husayn in the Muslim month of Muharram by Shī'ah Muslims. The Muharram processions, which are not unlike Christian commemoration of the passions of Christ on Good Friday, continue to be one of the major Shī'ah religious ceremonies. ${ }^{302}$ These annual ceremonies were sanctioned and encouraged by the leaders of the early Shī'ah community -and notably by the Shī'ah Imāms who succeeded Husayn. ${ }^{303}$ The Shī'ah Imāms also encouraged their followers to use the opportunity of commemorating Husayn's martyrdom to revisit the central notions of Wilāyah and Walāyah in Shī'ah Islam. ${ }^{304}$ One can conceive of at least two strategic implications of these commemorations. First, they functioned as an annual reminder of a

${ }^{301}$ See Enayat, Hamid. Modern Islamic Political Thought. p. 183.

${ }^{302}$ Throughout centuries, the processions of Muharram have developed into an elaborate and complex ritual with cultural, social, and indeed political implications. The processions often extend the first ten nights of the month of Muharram culminating in the massive processions of $10^{\text {th }}$ of Muharram -the day of 'Āshūrā. Most devout Shī'ah Muslims, however, observe a general attitude of sorrow for the following forty days i.e. till the end of the Muslim month of Șafar. The processions have entered into the realm of public arts in the form of a genre of dramatic representations called Ta $\mathrm{C}^{\mathrm{z}} \mathrm{y}$ ih. On $10^{\text {th }}$ of Muharram, artists reproduce the events of Karbalā and the martyrdom of H̦usayn in Ta'zīyih. See Malekpour, Jamshid. (2004). The Islamic Drama. Portland: Frank Cass Publishers. Professor Richard Bulliet believes that the formal "ritual" of commemorating the martyrdom of Husayn was first developed during the reign of the Shi' ${ }^{\prime}$ ah Būyid dynasty in Persia in the tenth and eleventh centuries [R. Bulliet, personal communication, March 5, 2010]. See also Enayat, Hamid. Modern Islamic Political Thought. p. 181-2.

303 See 'Allāmih Majlisī, Biḥār al-Anwār, Vol. 98, pp. 1-106 for numerous reports regarding commemoration of Husayn on various religious occasions as well as by making pilgrimage to the site of his martyrdom.

304 See Chapter V and 'Allāmih Majlisī, Bihāar al-Anwār, Vol. 71, p. 354. In the Hadīth reported by 'Allāmih Majlisī, the Shī'ah Imām encourages his followers to meet each other frequently and to use every gathering opportunity "to revive and strengthen the Imām's Amr." Here, Amr, which can loosely be translated into "affairs," appears to refer to the Imām’s Wilāyah and Walāyah. 
turning point in the history of Shī'ah Islam. ${ }^{305}$ It caused socialization and internalization of a strategic attitude towards pain, loss, and suffering. Secondly, the processions functioned as a hallmark ritual of Shī'ah Muslims to distinguish them from the majority Sunnī Muslims. As a collective effort towards an elaborate ceremony, it also strengthened the community bonds much needed for a minority group to survive.

While informing the collective identity of Shī'ah Muslims, the events of Karbalā began to be theorized by prominent Shī'ah jurists. The effort aimed at reconciling Husayn's assertive and proactive actions on the one hand and other Shī'ah Imāms' political "quietism" on the other. As will be discussed in Chapter V, the notions of Wilāyah and Walāyah were central in the accommodation of the two seemingly contradictory approaches within a single theological framework. To the early Shī'ah jurists, however, a primary theological challenge was the tension between Husayn's journey to Karbalā and the Qur'ānic prohibition against self-destruction expressed in the verse 2:195. The verse categorically rejects committing suicide. ${ }^{306}$ As will be discussed in the following Chapter, the universal prohibition of self-destruction in this verse has served as one of the main theological justifications for the doctrine of Taqīyyah in Shī'ah Islam. One of the general deductions drawn from the verse has been, for instance, the limits of a Muslim's duty "to enjoin the good and to prohibit the evil." Shī'ah jurists often argue that if such an enjoining or prohibiting may lead to one's destruction, one must

\footnotetext{
${ }^{305}$ The martyrdom of Husayn in Karbalā was a major turning point in Shī'ah history and not, as some scholars have claimed, the starting point of Shī'ah Muslims as a community. As will be discussed in Chapter V, the distinct foundation of Shī'ah Islam compared to Sunnī Islam has been the notions of Wilāyah and Walāyah going back to the time of the Prophet.

306 “Make not your own hands contribute to (your) destruction” [2:195, Yūsuf ‘Alī’s translation].
} 
avoid it. The fact that Husayn had framed his journey towards Karbalā as an attempt to "enjoin the good and prohibit the evil"307 along with the mainstream Shī's belief that he had known the result of this journey created a major theoretical dilemma for Shī'ah jurists.

The early generations of Shī'ah jurists resolved the tension by explicitly or implicitly suggesting that Husayn was not certain about his coming death when he embarked on the journey towards Küfah. Some of these jurists have argued that, given his high stature in the Muslim society, Husayn felt he would not be harmed. Some prominent Shī‘ah jurists such as Shaykh al-Mufīd, al-Sharīf al-Murtaḍā (d. 1044 C.E.), Shaykh alṬūsī, and Amīn al-Islām Ṭabarsī (d. 1153 C.E.) have suggested this line of argument. ${ }^{308}$ The belief in Husayn's incertitude about his fate was later on rejected by the mainstream Shī'ah jurists as well as the laity. During the early centuries of Shī'ah Islam, the notion of 'Ișmah -or the "infallibility of the Imāms"- gradually became an established Shī' $\overline{1}$ popular belief. Meanwhile, the notion was further elaborated by various Shī‘ah jurists and theologians. The far-reaching implications of the belief in the infallibility of the Imāms and the "Imām's penetrating knowledge of the universe" contradicted ${ }^{309}$ the arguments

\footnotetext{
${ }^{307}$ See ‘Allāmih Majlisī, Bihāar al-Anwār, Vol. 44, p. 329.

${ }^{308}$ See, for instance, Shaykh al-Mufĩd, al-Masā'il al- 'Akbarīyyah; al-Sharīf al-Murtaḍā, Tanzīh al-Anbìyā'; Shaykh al-Ṭ̂ūī, Talkhīṣ al-Shāfí̀; and Amīn al-Islām Ṭabarsī, Majma 'al-Bayān.

${ }^{309}$ It is not difficult to find similar cases in early Shī' 'ah texts where the image and the status of the Shì ${ }^{\top} a h$ Imāms do not quite match the subsequent Shī'i belief in their infallibility and their extraordinary knowledge. In fact, scholars such as Mohsen Kadivar have used some of these texts to argue that early Shī'ah Muslims viewed their Imāms as "extremely knowledgeable and pious, yet fallible men." The reader can find other examples of the discrepancy between the current mainstream Shī'i belief in the infallibility of the Imāms on the one hand and the early depictions of them in Shī'ah sources on the other in Modarresi Tabatabaii, Hossein. Crisis and Consolidation in the Formative Period of Shi 'ite Islam.
} 
proposed by early jurists ${ }^{310}$ regarding Husayn's possible lack of certainty about his imminent death in Karbalā when he left Medina.

Arguably aware of the growing tension between the above solution and the belief in the infallibility of the Imāms, al-Sharīf al-Murtaḍā and Amīn al-Islām Ṭabarsī proposed another possible explanation. ${ }^{311}$ They argued that, given the increasing political pressure on Husayn to announce an oath of allegiance to Yazīd ibn Mu'āwīyah, Ḥusayn had really had no other choice. In other words, Husayn was to choose between humility of being forced to support Yazīd ibn Mu'āwīyah or an honorable death; and he chose the latter course. The explanation is further supported by Husayn's various statements comparing the two options. The above line of argument has received a more favorable response by later Fuqahā. These Fuqahā often viewed Huusayn's martyrdom as a watershed in Islam that had been predicted even by the Prophet himself. ${ }^{312}$ The above theological explanation was also important in shaping Shī's strategic cultures; for it projected Husayn's action -as a manifestation of Shahādah par excellence- to be a proactive one. It was a conscious decision made in accordance to the "principles" at a

\footnotetext{
${ }^{310}$ It must be noted that the above argument is not the only explanation proposed by Shaykh al-Mufid and other early Shī'ah jurists. There are other possible explanations offered by these jurists that are more compatible with the belief in the infallibility of the Imāms.

${ }^{311}$ See Murtaẓawī, S. Dia'. (1998). 'Āshūra dar Fiqh. Qum: Intishārāt Daftar Tablīghāt.

312 There are various secondary Shī'ah sources that attribute a number of Hadīths to the Prophet and 'Alī containing prophecies regarding the fate of Husayn and his martyrdom in Karbalā. These Hadìths often highly praise Husayn as a "chosen devotee" to God and depict his future journey towards his death as an epic one [see, for instance, Shaykh al-Islām al-Juwiynī, Farā'id al-Simțayn, Vol. 2; and al-Qundūzi alHanafī, Yanābi` al-Mawaddah li-dhawī al-Qurbā]. Various Shī'ah sources have also reported that, once about to leave Medina, Husayn wrote to his fellow clan members of Banī Hāshim to accompany him in his journey towards Kūfah. According to these reports, in this letter, Husayn predicted martyrdom for himself and his companions and humiliation for those of Banī Hāshim who stayed behind [see Ibn Shahr Āshūb, Manāqib Āl Abì Țālib, Vol. 3, p. 230; and Ḥasan ibn Sulaymān al-Ḥillī, Mukhtașar Bașā'ir al-Darajāt, p. 6. See also also 'Allāmih Majlisīi, Biḥ̄ar al-Anwār, Vol. 44, p. 310].
} 
time of severity and insecurity.

'Allāmih Hillī, however, took the discussion to a new level. ${ }^{313}$ His argument comes closer to Shī' $\overline{1}$ interpretation of Islam and the implications of the notions of Wilāyah and Walāyah. 'Allāmih Hillī argues that the decision for Hudnih, i.e. truce, ceasefire or peace treaty, and Harb, i.e. war, lies in the province of the Imām's authority. ${ }^{314}$ The authority comes from the Wilāyah of Imām or his exoteric status in the sacred and "metaphysical hierarchy" of the world. An Imām possesses an "extraordinary knowledge" of the "Reality" behind the various things and affairs. As such, he is wellpositioned, 'Allāmih Hillī argued, to choose the appropriate course of action at a given time and place. This is why Husayn's brother, Hasan, chose to conclude a peace treaty with Yazīd ibn Mu'āwīyah's father, while Husayn refused to acquiesce to the rule of Yazīd ibn Mu'āwīyah. Both actions are, according to 'Allāmih Ḥillī, equally legitimate and religiously warranted given the status of Hasan and Husayn as the "bearers of the Divine Wilāyah.” "Allāmih Ḥillī concludes that Ḥusayn could have chosen peace because of his legal and religious authority.

There is an important implication of 'Allāmih Hillī’s interpretation of Husayn's decision to fight, even though it was elaborated upon by later Fuqahā. The Wilāyah of the Imām means not only the legitimacy of his actions and decisions, but also the ultimate

\footnotetext{
${ }^{313}$ See Murtaẓawī, S. Ḍ. 'Āshūra dar Fiqh.

${ }^{314}$ For 'Allāmih Hillī’s extensive discussion of various legal aspects of Hudnih and Harb, see 'Allāmih Hillī, Tadhkirah al-Fuqahā', Vol. 9, pp. 5-390. Another prominent jurist, Shahīd al-Thānī, -i.e. the Second Martyr-, also accepts 'Allāmih Ḥillī’s argument regarding Ḥusayn's decision to fight [see Murtazâwī, S. D. 'Āshüra dar Fiqh; Shahīd al-Thānī, Masālik al-Afhām ilā Tanqīh Sharāyi' al-Islām, Vol. 3, pp. 5-96; and Ibid. Vol. 13, pp. 228-30].
} 
expediency embedded in such actions and decisions. ${ }^{315}$ Since the Imāms are, according to Shī ${ }^{‘} \overline{1}$ beliefs, an essential part of the Divine design for the humanity, their actions are in line with the ultimate goal of creation. Such goal is inherently benevolent. This means that Husayn's refusal to accommodate Yazīd ibn Mu'āwīyah's rule and his death in Karbalā was necessary in the grand scheme of events that were to follow, even though in the short run the decision might have appeared to be futile. ${ }^{316}$

Muhaqqiq al-Karaki ${ }^{317}$ made the next important contribution to the jurisprudential study of Husayn's martyrdom in Karbalā. Murtazawī reviews the major points of differentiation between 'Allāmih Ḥillī and Muhaqqiq al-Karakī regarding the issue of war and peace. ${ }^{318}$ 'Allāmih Hillī in Tadhkirah al-Fuqahà' argues that in no condition Mudāhinah, i.e. opting for truce or peace treaty, is religiously "obligatory," or al-Wājib. Such a course of action may be, nonetheless, legitimate if the expediency and concerns for the Shī'ah community's survival demand it. ${ }^{319}$ The argument was in line with

\footnotetext{
315 The notion of expediency and prudence is particularly associated with the decisions regarding Hudnih, i.e. truce and peace treaties, in Shī'ah juridical texts. The stark contrast between the peace treaty of "Imām Hasan" and the martyrdom of "Imām Husayn" has demanded quite a large number of theoretical efforts by Shi' 'ah theologians aimed at resolving the seeming tension. One outcome of these efforts has been further theorization of the notion of prudence and its legitimacy based on Hasan's peace treaty with Mu'āwīyah ibn Abī Sufyān. In the following Chapter on expediency, a brief analysis of this peace treaty in shaping Shī's strategic cultures is offered.
}

\footnotetext{
316 The notion that Husayn's martyrdom in Karbalā was meant to be an essential step in the progress of Islam as the final message of God is seared into Shi ${ }^{-} \overline{1}$ collective imagination. There are many references to this image of Karbalā as the "guarantor of Islam's future." Ayatollah Khomeini, for instance, declared that "it has been Muharram and Șafar [i.e. the two months in Muslim calendar associated with the events of Karbalā and the commemoration of Husayn's martyrdom by Shī'ah Muslims] that have protected Islam" [see Ayatollah Khomeini, Șahịfih Nür, Vol. 15, p. 330. Retrieved from www.tebyan.net on January 23, 2012].

${ }^{317} \mathrm{He}$ is also known as Muhaqqiq al-Thān̄̄.

${ }^{318}$ Murtaẓawī, S. Ḍ. 'Āshūra dar Fiqh, pp. 51-7.

${ }^{319}$ See ‘Allāmih Hiillī, Tadhkirah al-Fuqahā', Vol. 9, pp. 352-9 -see p. 358 in particular.
} 
‘Allāmih Ḥillī’s other assertion that Ḥusayn's decision to fight was a choice between two religiously allowed courses of actions, i.e. war against injustice or an expedient peace.

In contrast, Muhaqqiq al-Karakī argues that opting for truce may become religiously obligatory for the Imām if the community's survival is hinged upon it. ${ }^{320}$ As Murtazawī notices, Muhaqqiq al-Karakī specifically refers to the Qur'ānic command against self-destruction. ${ }^{321}$ According to him, the absolute terms of this verse circumscribe any seemingly universal command for war in Islam. Muhaqqiq al-Karakī’s argument also implies that the survival of Shī'ah community at the time did not hinge upon Ḥusayn’s refusal to militarily engage his enemies.

In Muhaqqiq al-Karakī’s theological reading of the events of Karbalā, one may find an example of what was to become the mainstream Shì'is understanding of those events. He argues that Husayn's decision to fight could have been the result of a number of considerations: that he did not trust Yazīd ibn Mu'āwīyah would at least in appearance respect a treaty; that, as some historical sources have argued, there was no real offer of truce and political "quietism" to begin with; that he believed the actual choice was between a humiliating death and an honorable one; and that he saw in a humiliating truce

\footnotetext{
${ }^{320}$ Murtaẓawī, S. Ḍ. 'Āshūra dar Fiqh, pp. 51-7; and Muhaqqiq al-Karakī, Jāmi 'al-Maqāṣid fì Sharh alQawā'id, Vol. 3, pp. 466-81 -see p. 467 in particular. Murtaẓawī also reviews Sayyid 'Alī Țabātabā'î̀s response to 'Allāmih Hillī. Similar to Muhaqqiq al-Karakī, Sayyid 'Alī Țabāṭabā'ī rejects the notion that Husayn could have opted for peace without violating his religious duty. He mentions that reviving the tradition of the Prophet was the most important consideration, i.e. Maṣlahah A'zam or "the greatest expediency." Sayyid "Alī Țabāțabā'ī also offers an interesting observation regarding the historical and social context of Husayn's decision. According to him, the Shī'ah community had been discontented with the peace treaty that Husayn's brother, Ḥassan, had concluded with Mu'āwīyah ibn Abī Sufyān. Many Shī'ah Muslims believed that the treaty was a humiliating one. Sayyid 'Alī Țabățabā' $\overline{1}$ argues that given the level of discontent in the community, had Husayn opted for a truce, it would have destroyed the morale of

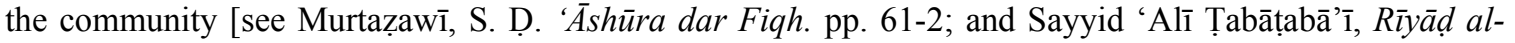
Masā’il fì Bayān Aḥkām al-Shar' bil-Dalā'il, Vol. 7, pp. 494-9 -see p. 497 in particular].

${ }^{321}$ See the verse 2:195 in the Qur'ān.
} 
with Yazīd ibn Mu'āwìyah a major damage to the "foundations of Islam." Therefore, in contrast to 'Allāmih Hịllī, Muḥaqqiq al-Karakī did not see in the actions of Ḥusayn a possible justification for the universal application of the doctrine of Shahādah. Instead, the decision for war and almost certain martyrdom was shaped to a great extent by exceptional historical, social, and psychological contexts of the time. This is further supported by the fact that, as discussed before, Husayn absolved his companions of their oaths of allegiance and allowed them to leave.

The question of Hudnih, i.e. truce or peace treaty, versus Shahādah continued to be a theological problem for many Shī'ah theologians and jurists. The underlying strategic question was, however, when and where Shī'ah Muslims should emulate Husayn's Shahādah and when and where they should follow Hasan's peace treaty. It seemed that the Qur'ān provided enough support for both sides of the argument. ${ }^{322}$ Therefore, Shī'ah theologians had to tackle the question of war and peace with their analytical and textual skills. For a minority community under constant threat of extinction, the answer to this theological question would have had significant implications. In his encyclopedia of the Shī'ah jurisprudential traditions, ${ }^{323}$ Muhammad Hasan al-Najafî ${ }^{324}$ reviews various juridical opinions regarding Hudnih and tries to strike a balance between appreciation of necessities and that of survival on the one hand and the "idealist" doctrine of Shahādah on the other. Similar to Muhaqqiq al-Karakī, al-Najafī

\footnotetext{
${ }^{322}$ While the verse 2:195 was interpreted as a categorical prohibition against self-destruction, verse 2:244 appeared to be a universal invitation to "fight in the cause of God."

${ }^{323}$ Jawāhir al-Kalām fì Sharh Sharāyi ' al-Islām is a multi-volume collection of Shī'ah juridical discourses and the opinions of prominent Shī'ah jurists of the past.

${ }^{324}$ d. 1850 C.E.
} 
views Husayn’s martyrdom as an extreme and exceptional case. ${ }^{325}$ Husayn’s actions, he argues, should be understood in the light of the extraordinary circumstances as well as Husayn’s special status - even arguably among the Shī'ah Imāms. As such, it does not relieve Shī'ah Muslims' from their duty to be cautious and judicious in protecting themselves, their religion and their community either through peace or war. ${ }^{326}$ The line of argument has been the main reason why few Shī'ah jurists have dealt with the events of Karbalā as direct sources of religious reasoning, or Ijtihād. In other words, many Shī‘ah jurists perceived Ḥusayn's unique action -compared to those of other Shī'ah Imāms-as a

tradition beyond the realm of Ijtihād. Instead, the story of Husayn became the epic story of Shī'ah community and one of the pivotal foundations of their self-perception.

The above understanding of the doctrine of Shahādah as the last measure -and reserved for extraordinary circumstances- has been a mainstream paradigm among Shī'ah jurists regarding the matter. The paradigm projected the story of Husayn as the metaphor of an "ideal life," a life that could serve to inspire Shī'ah Muslims but could not be imitated by them. ${ }^{327}$ The most significant exception to this mainstream interpretation belongs to Ayatollah Khomeini. While acknowledging the special status of Husayn,

\footnotetext{
${ }^{325}$ See Muḥammad Ḥasan al-Najafì, Jawāhir al-Kalām fì Sharh Sharāyi 'al-Islām, Vol. 21, p. 3-50; and Ibid., Vol. 21, p. 295.

${ }^{326}$ See Ibid., Vol. 21, pp. 295-6; and Murtazawī, S. D. 'Āshūra dar Fiqh. pp. 68-9.

327 This understanding of Husayn's "idealistic" martyrdom continues to exist to this day. As recent as 2011, Grand Ayatollah Wahīi al-Khurāsānī reiterated the tenets of this interpretation in his message for 2011 annual commemoration of the events of Karbalā. His articulation is particularly important for Wahīi alKhurāsānī is arguably the most prominent "traditional" Marja' in Qum's Shī'ah seminary and is considered by many to be the head -i.e. Za'īm- of that seminary. His understanding of the "lessons of "Āshūrā" follows the mainstream Shi' $\overline{1}$ approach and differs decidedly with that of Ayatollah Khomeini [see www.vahid-khorasani.ir, Retrieved November 28, 2011].
} 
Ayatollah Khomeini took issues with the notion that Husayn's action was beyond jurists' reasoning. Similar to other reported traditions of the Prophet and the Shī'ah Imāms, Ayatollah Khomeini argued, Husayn's martyrdom and the events of Karbalā might be used as a source for religious jurisdiction. ${ }^{328} \mathrm{He}$ acknowledged that Husayn's "extraordinary sacrifice" had been for the higher purpose of protecting the "core of Islam." Yet, he argued that a qualified Shī'ah jurist might as well recognize a moment of such vital threat to Islam. ${ }^{329}$ Upon such recognition, Ayatollah Khomeini believed, the jurist could refer to Husayn's tradition and employ the doctrine of Shahādah. He then offers a number of examples to show what he means by a vital threat to the core of Islam. These include "a threat to the lives or dignity of a group of Muslims," "a threat to destroy the traditions of Islam," "an attempt to remove a "validating proof' [i.e. Hujjat] of Islam," and "an attempt to destroy the supreme signs and symbols of Islam [i.e. Sha'à'ir alIslām]"- such as the house of Ka'bah in Mecca. Once such a threat is looming, a Shī'ah jurist could not side with "short-term expediency," refer to political prudence, or resort to the doctrine of Taqīyyah, Khomeini argued. Indeed, the reference to "the lives or dignity of a group of Muslims” in his argument can be applied to the Shī'ah Muslims as a whole as well as smaller Shī'ah minority communities. The argument brings the doctrine of Shahādah to the fore of Shī'̄ì strategic culture according to Ayatollah Khomeini. On the practical level, he employed this doctrine in formulating Iran's war with Iraq in the 1980s. The "forgotten" doctrine of Shahādah was revived as the tradition of "Imām

\footnotetext{
${ }^{328}$ See for instance Ayatollah Khomeini, Șahĭfih Nür, Vol. 1, p. 164; Ibid. Vol. 7, p. 54; and Ibid. Vol. 17, pp. 58-9. Retrieved from www.tebyan.net on January 23, 2012.

${ }^{329}$ See Murtaẓawī, S. Ḍ. 'Āshūra dar Fiqh. p. 74; and Ayatollah Khomeini, Tahrī̄r al-Wasīlah, Vol. 1, p. 472 .
} 
Husayn" to protect Shī'ah Iran. For this reason, Mesbahi argues that the doctrine of Shahādah was the "backbone of Iran's national security strategy during the war with Iraq." 330 Yet, as Mesbahi notes, the "national security strategy" was not purely nationalistic. The defensive war was not merely about protecting Iran as an independent national unit against the invading Iraq. It was also about protecting Iran as the bastion of Shī‘ah Islam.

This brings us to the more consequential item on the list of examples specified by Ayatollah Khomeini. He refers to 'validating proofs,' i.e. Hujjat ${ }^{331}$, of Islam as something to be carefully protected. Without these 'validating proofs,' people would get bewildered about the religion and they might go astray, he maintained. One of the supreme examples of these 'validating proofs' in Shī'ah Islam is the sacred hierarchies of Wilāyah and Walāyah. It was, as discussed above, in protest against the grave violation of Wilāyah by Yazīd ibn Mu'āwìyah that Husayn laid his life on the line. It was, Khomeini claimed, the serious violation of the same sacred notion by the Shah that allowed Khomeini to employ the doctrine of Shahādah in his struggle against the Pahlavī dynasty. ${ }^{332}$

Ayatollah Khomeini also brought the above argument to its logical extreme. He asserted that Shī'ah Muslims are obliged not only to protect Wilāyah once threatened,

\footnotetext{
${ }^{330}$ M. Mesbahi, Interviews, Spring 2010, and Mesbahi, Mohiaddin. Free and Confined. See also Mesbahi's chapter on Iran-Iraq War in Rajaee, Farhang. (Ed.). (1993). The Iran-Iraq War: The Politics of Aggression. Gainesville: University Press of Florida.

331 The plural for Hujjat is Hujaj.

${ }^{332}$ For a related analysis of Ayatollah Khomieni's direct comparison of Husayn's martyrdom and his own fight against the Shah, see Enayat, Hamid. Modern Islamic Political Thought. p. 194.
} 
they must also strive to establish Wilāyah once it has been destroyed. ${ }^{333} \mathrm{He}$ argued that Husayn’s journey towards Kūfah was a proactive act of "volunteerism" to establish an "Islamic state" based on Husayn's Wilāyah. Ayatollah Khomeini rejected the interpretations of Muhaqqiq al-Hilllī and Șāḥib al-Jawāhir ${ }^{334}$, who had suggested that once in Karbalā, Husayn had had no option but to fight. Instead, Khomeini saw the decision to go to Kūfah as an essentially deliberate one despite Husayn's knowledge of its fate. Husayn's Wilāyah demanded, in other words, a journey that would end in martyrdom. ${ }^{335}$

It is not surprising, therefore, that one of the outcomes of the Iranian Revolution has been a political structure built upon Ayatollah Khomeini's theory of Wilāyat Faqīh. ${ }^{336}$

\section{The Mystical Dimension of Shahādah}

Before visiting the implications of Husayn’s martyrdom for Shī's understanding of Jihād, it is worth discussing the mystical theme of Shahādah in Shī'ah Islam. Shī'ah Muslims trace this mystical theme to a Prophetic tradition. ${ }^{337}$ In addition, there exists the

\footnotetext{
${ }^{333}$ As far as the author is aware, Ayatollah Khomeini has not offered a systematic explanation of Hasan's peace treaty or Husayn's nearly one decade of political "quietism," although the Imāms' Wilāyah was arguably challenged in both cases.

${ }^{334}$ Muhammad Ḥasan al-Najafi [see above].

${ }^{335}$ See for instance Ayatollah Khomeini, Sahifih Nūr, Vol. 1, p. 164; Ibid. Vol. 7, p. 54; and Ibid. Vol. 17, pp. 58-9. Retrieved from www.tebyan.net on January 23, 2012.
}

${ }^{336}$ A brief discussion of the notion of Wilāyat Faqīh is offered in Chapter V. For more information, see Ayatollah Khomeini's Hukümah al-Islämīyyah. Mesbahi offers an insightful analysis of various ramifications of Ayatollah Khomeini's political theory for Iran's modern politics. This includes arguably the first $S^{\top}{ }^{`} ' \overline{1}$ articulation of the self-referential institution of the modern state [M. Mesbahi, Lectures, Fall 2007, and M. Mesbahi, Interviews, Fall 2011].

${ }^{337}$ In particular, Shī'ah sources refer to a reported conversation between the Prophet and Hārithih ibn Mālik, one of his disciples. When Hâarithih ibn Mālik conveyed to the Prophet the "extraordinary spiritual visions" he had received, he asked the Prophet to pray so that God "grants him martyrdom." The Prophet did so and shortly after, Ḥārithih ibn Mālik was killed in a small battle [see "Allāmih Majlisī, Biḥār al- 
Șūfi treatment of the notion of Shahādah. As discussed before, the word Shahādah essentially means to testify and Shahīd is the one who testifies. In the Șūfì literature, it is not unusual to find the term Shahīd in reference to those Șūfìs who have achieved the highest level of mystical experience, namely the experience of unification with God. Since such an experience involves, Șufis believed, the annihilation of one's self in the Divine Self, it implied a sort of demise or "martyrdom." At the same time, according to Șūfĩ doctrines, by sacrificing one's self in the Divine Self, a Șūfĩ would testify the ultimate Truth of Unity -and that there is no being other than the Being. For these reasons, the word Shahīd, which implies both testimony to the Truth and martyrdom, has been an apt term for the Șûfis describing their ultimate religious experiences. Such experiences were also tied to the notion of Walāyah, which is central in various Șuffi traditions of Sunnī or Shī‘ah origins. A Șūfĩ Shahīd was also believed to be a "bearer of the Divine Walāyah" for he or she had ascended through the esoteric and "metaphysical" sacred hierarchy -a hierarchy that the term Walāyah signified.

In the context of Shī'ah Islam, therefore, it is not surprising that the doctrine of Shahādah had obtained a mystical undertone after the events of Karbalā. Not only Husayn literally sacrificed his self in the way of testifying the "ultimate Truth" of Islam, but also he was the supreme "bearer of Walāyah" at the time according to Shī'ahs. ${ }^{338}$ As

Anwār, Vol. 67, p. 174; and Abū Ja'far Thiqat al-Islām Kuliynī, Ușūl al-Kāfí, Vol. 2, p. 54]. According to Sh̄̄'ì interpretations of this report, H̦ārithih ibn Mālik's mystical experience culminated in his desire to thoroughly sacrifice himself through martyrdom. This notion of "mystical martyrdom" was further elaborated by the Shī'ah Imāms and some of the Shī'ah theologians later on.

${ }^{338}$ In fact, one of the longest and most popular "mystical prayers" in Shī'ah Islam, i.e. the prayer of "Arafah, belongs to Husayn who first recited it in his last pilgrimage to Mecca just before embarking on his final journey to Kūfah. The correlation between the "ultimate spiritual experiences" of the Shī'ah Imām on the one hand and Shahādah on the other in Shī's beliefs is not limited to Husayn. Shī'ah Muslims consider all their Imāms to be Shahīd even though only Husayn was killed on the battlefield. All other Shī'ah Imāms 
such, Husayn's martyrdom was more than fulfilling a religious duty in the eyes of Shī'ah Muslims. It was also a gratifying mystical experience of unification with God -albeit appearing physically painful. ${ }^{339}$ Similar to the epic Bhagavad-Gita in Hinduism, Husayn's martyrdom in Karbalā turned the experience of battlefield in Shī'ah Islam into an extremely elaborate mystical experience of the highest order. The mystical flavour of Karbalā, of course, does not mean that "mysticism" has become a driving force in Shī' $\overline{1}$ strategic cultures.

The involvement of the hierarchies of Wilāyah and Walāyah in the Shī's doctrine of Shahādah has had yet another strategic implication. The "blissful state of martyrdom" cannot be achieved unless permission is granted by an appropriate religious authority, i.e. an authority that bears a certain level of Wilāyah and in some cases Walāyah. This is why the overwhelming majority of Shī'ah jurists have argued that "offensive wars" are forbidden unless with the direct permission of an "infallible" Shī'ah Imām. ${ }^{340}$ A Shī'ah killed in an "offensive battle" without such permission will not be considered a martyr according to this ruling. In addition, many Shī'ah jurists hold that a "defensive war" is

were killed in circumstances other than war. Yet their deaths are often understood as their final act of testimony to the Divine Truth and as the "ultimate mystical experience" of Shahādah. This connection is further solidified by a Hadīth attributed to the sixth Shī'ah Imām, Ja 'far ibn Muhammad, in which he says that "[t]here is [and will be] no one among us [i.e. the Shī'ah Imāms] not killed as a martyr" [see 'Allāmih Majlisī, Bihāar al-Anwār, Vol. 27, p. 209].

To further emphasize the "mysticism" of Shahādah, both "Alī and Hasan -i.e. the first and the second Shī'ah Imāms- have argued that a "true Shī'ah" is eventually a martyr regardless of how he or she dies for he or she will "achieve the Sacred Knowledge of the Divine Truth" upon death [see Ibn Abī al-Hadīd, Sharh Nahj al-Balāghah, Vol. 13, p, 111; and Shaykh Hādī al-Najafì, Mūsū 'ah Ahāaìth Ahl al-Bayt, Vol. 8, p. 357].

339 The mystical interpretations of Ḥusayn's martyrdom is not exclusive to Shī‘ah Muslims. Jalāl al-Dīn Rūmī, the prominent Sunnī Șūfī poet (d. 1273 C.E.), venerates his martyrdom as a supreme case of mystical union with God [see Jalāl al-Dīn Rūmī, Mathnawì al-Ma 'nawì, Vol. 6, Verses 792-805].

${ }^{340}$ See Faghfoory, Mohammad H. Ethic of War and Peace in Shi‘ite Islam. 
legitimate only when a qualified jurist sanctions it. ${ }^{341}$ It is only with such a sanction that those killed in a "defensive war" are considered martyrs. In both juridical arguments above, the Shī'ah jurists have relied on the notions of Wilāyah and Walāyah. The extreme nature of "offensive wars" demands the supreme religious authority of the "infallible" Imāms who, according to Shī‘̄ì beliefs, possess both Wilāyah and Walāyah. ${ }^{342}$ "Defensive wars," although less controversial, still require a partial level of Wilāyah, or exoteric

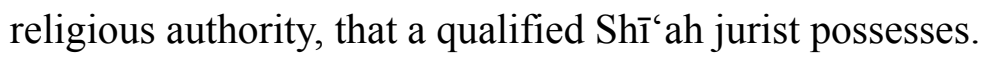

\section{Shī'ah Understanding of Jihād}

Besides their effects on shaping the Shī's doctrine of Shahādah, the events in Karbalā had another important consequence. They left an enduring mark on Shī'i understanding of Jihād. In recent decades and especially following the collapse of the Soviet Union, much has been written about the notion of Jihād in Islam. Yet, the essential difference between the $\operatorname{Sh}^{\top}{ }^{‘} \overline{1}$ and the Sunnī interpretations of this notion has often been overlooked. The Arabic word Jihād means, inter alia, exertion. Similar to the phrase Shahādah, Jihād has been used in Muslim religious discourses in various ways. Many of the scholars of Islam have already pointed to the incorrect translation of Jihād as "Holy War." ${ }^{, 343}$ In traditional Muslim literature the primary meaning of the term Jihād is exertion

${ }^{341}$ Ibid.

${ }^{342}$ As will be discussed later, there seems to be a general consensus among Shī'ah jurists regarding this matter. Mullā Muḥsin Fiỵ̣ Kāshān̄i, for instance, explicitly rejects the possibility of "offensive war" during the Occultation of the twelfth Imām [see the book of Jihād in Mullā Muhssin Fiỵ̣ Kāshānī, Mafātīh alSharāyi '].

343 A prominent example of modern "Orientalist" literature in this regard is Lewis, Bernard. (2004). The Crisis of Islam: Holy War and Unholy Terror. New York: Random House. For different analyses of Jihād in Islam, see Schimmel, Annemarie. (1992). Islam: An Introduction. Albany: State University of New York 
implying struggle with the ego. As such, sacrificing one's comfort and life on the battlefield for a religious cause may be considered as one of the manifestations of Jihād. ${ }^{344}$ Accordingly, Muslim "just wars," or "religiously sanctioned" wars, are considered an example of Jihād by the virtue of being an extension of believers' continuous fight against their egos. While acknowledging this broader context of the term Jihād, this section focuses on the perception of external Jihād, or physical wars, by Shī‘ah Muslims; for the purpose of this section is to better understand the narrative of "just war" in Shī‘ 1 strategic cultures as well as their "metaphysical dimensions.",345

In Sunnī Islam, there seems to be more continuity in the general perception of "just wars" from the time of the Prophet to the present time. Throughout his career as a statesman, the Prophet engaged in a number of battles ${ }^{346}$ with disbelievers, or "infidels."

Press. pp. 68-70; Nasr, Seyyed Hossein. (Fall 1982). The Spiritual Significance of jihãd. Parabola, 7(4), 14-19; and Shah-Kazemi, Reza. (Summer 2009). Recollecting the Spirit of Jihad. Sophia Perennis, 1(3), 23-51].

${ }^{344}$ The often quoted reference in this regard is a Hadith by the Prophet in which he refers to the external war as the smaller Jihād, i.e. Jihād al-Asqar, while praising the inner war of the soul against the ego as the greater Jihād -i.e. Jihād al-Akbar [see Shaykh al-Ṣadūq, Ma 'ānī al-Akhbār, p. 160]. Similar sayings have been reported from 'Alī and Muhammad ibn 'Alī, the first and the fifth Shī'ah Imāms. In these Hadīths, "Jihād with the ego" is often considered as the "most superior" and the "most difficult" of all Jihāds [see, for instance, Ibn Shu'bah al-Ḥarrān̄̄, Tuhaf al- 'Uqūl, p. 286; and al-Ḥurr al- 'Āmilī, al-Fuṣūl al-Muhimmah fì Ușül al-A'immah, pp. 214-24]. 'Alī considers the death of one who has been in constant struggle with his or her ego to be martyrdom. The verse 25:52 of the Qur'ān has also been interpreted as praising the "great Jihād" when referring to strivings for faith and belief [see Faghfoory, Mohammad H. Ethic of War and Peace in Shi'ite Islam].

${ }^{345}$ From this point onward, therefore, wherever the term Jihād is used it means external Jihād unless otherwise clarified.

${ }^{346}$ The most significant of these battles are the Battle of Badr (624 C.E.), the Battle of Uhud (625 C.E.), the Battle of Khandaq (otherwise known as the Battle of Trench in 627 C.E.), and the Battle of Hunayn (630 C.E.). In addition to these battles, the Prophet sealed a large number of peace and truce treaties with various tribes and clans. Prominent among these is the Hudaybiyyah Peace Treaty that was concluded in 628 C.E. between the Prophet and the Meccan disbelievers. The Prophetic tradition of peace treaties has functioned as a sort of counter-balance to his wars. This "counter-tradition" has been used by those Muslim jurists who have argued for the centrality of peace in Islam. For more information on the Prophet's wars and peace treaties, see Muḥammad ibn Jarīr al-Ṭabarī, Tārīkh al-Tabarī, Vol. 2, pp. 131-385. 
The logic behind these battles, it is often argued, was to spread Islam or to secure the interests and the survival of the emerging and vulnerable Muslim community. ${ }^{347}$ On the whole, one essential feature of these wars was that they were fought between believers and "infidels." This continued to be the essential feature of Muslim wars during the time of the first three of the "Rightly Guided Caliphs." ${ }^{348}$ More or less similar

conceptualization of "just wars" against "infidels" survived during the Umayyad, the Abbasid and the Ottoman empires. ${ }^{349}$

Given the above historical context, the first Muslim civil wars that occurred during the caliphate of ' $\mathrm{Al}^{350}$ did appear to be great anomalies. As a result, the Sunnī sources have often described the period of these civil wars as the time of Fitnah, which implies great confusion and perilous disorder. The notion that two Muslim parties had engaged in war with each other created quite a number of theological dilemmas. It was not clear, according to Sunn̄̄ point of view, whether such wars were religiously legitimate. Since these civil wars did not lend themselves to the tradition of the Prophet,

\footnotetext{
${ }^{347}$ Montgomery Watt offers some useful scholarship in terms of the historical context of the Prophet's life and his wars. His interpretations and analyses, however, are not always beyond dispute. See Watt, W. Montgomery. (1961). Muhammad: Prophet and Statesman. Oxford: Oxford University Press; and Watt, W. Montgomery. (1981). Muhammad at Medina. Oxford: Oxford University Press. See also Lings, Martin. (2006). Muhammd: His Life Based on the Earliest Sources. London: Inner Tradition.

348 For mainstream Muslim historiography of the reign of the four "Rightly Guided Caliphs," see Muhammad ibn Jarīr al-Ṭabarī, Tārīkh al-Ṭabarī, Vol. 2, pp. 445-661; Ibid. Vol. 3; and Ibid. Vol. 4, pp. 2120.

${ }^{349}$ See Feirahi, Davoud. Tārīkh Tahawwwūl Duwlat dar Islām. pp. 344-6.

350 These included the Battle of the Jamal (or Camel in 656 C.E.), the Battle of Șiffin (657 C.E.) and the Battle of Nahrawān (658 C.E.). For some more discussion, see the following Chapter.
} 
it was also not clear whether they could be considered as Jihād. The theological predicament becomes yet more disturbing when one considers the parties involved in these battles. In the Battle of Jamal, 'Alī and some prominent disciples of the Prophet fought against 'Āyishah bint Abī Bakr, ${ }^{351}$ the beloved wife of the Prophet, and two other prominent disciples $^{352}$ of his. Similarly, in the Battle of Șiffĩn some disciples of the Prophet fought against each other. ${ }^{353}$ In the Battle of Nahrawān, 'Alī fought against Khawārij, an outwardly pious group of Muslims. ${ }^{354}$ Many Sunn̄̄ jurists, therefore, refrained from definite judgments regarding these wars. They often lean towards 'Alī's position for he was, after all, one of the "Rightly Guided Caliphs." Yet, they usually hesitated to go beyond admonishing the opposing parties in these battles for breaking the "sacred unity" of the Ummah. ${ }^{355}$ Since there was no "disbeliever" side in these battles,

\footnotetext{
${ }^{351}$ d. 678 C.E.
}

${ }^{352}$ These two prominent disciples were Zubayr ibn 'Awwām (d. 656 C.E.) and Ṭalhah ibn 'Ubaydullāh (d. 656 C.E.). It must be mentioned that as the war was to break out, Zubayr ibn 'Awwām left the battlefield following a reported conversation with his former companion 'Alī. For more discussion, see the following Chapter.

${ }^{353}$ In the Battle of Șiffin, 'Ammār ibn Yāsir who was one of the foremost disciples of the Prophet was killed at the age of ninety one by fellow Muslims in the army of Mu'āwìyah ibn Abī Sufyān. The killing of a highly venerated disciple of the Prophet by a Muslim was such a terrifying development that, reportedly, brought the war into a pause momentarily [see Nașr ibn Muzāḥim al-Minqarī, Waqa 'ah Șiffin, pp. 342-5].

354 This group, Khawārij, was a literalist Muslim movement. A brief introduction of this group can be found in Chapter II. 'Alī was eventually assassinated by a member of the same group.

${ }^{355}$ See Muhammad ibn Jarīr al-Ṭabarī, Tārīkh al-Tabarī, Vol. 3 and Ibid. Vol. 4; as well as Ibn al-Athīr, alKämil fïl-Tärīkh, Vol. 3. It must be noted that Sunnī scholars who belong to the Shāfi'i School of jurisprudence have been sometimes less forgiving in their assessment of the opponents of 'Ali, and particularly in regard to Mu'āwīyah ibn Abī Sufyān. In general, however, Sunnī Muslims respect 'Alī, 'Āyishah bint Ab̄̄ Bakr, and Mu'āwīyah ibn Abī Sufyān. It is also worth noting that Ash'arīs usually consider the dead on both sides of these battles to be martyrs while Mu'tazilīs are in general less clear in their judgement [see various discussion of Muslim attitudes towards Așhāa al-Jamal and Aṣhāb al-Ṣiffīn in Abū al-Fatḥ Shahristānī, al-Milal wal-Niḥal, Vol. 1]. 
many Sunnī jurists avoided calling them Jihād, and those killed in these wars martyrs. ${ }^{356}$

The theological dilemmas regarding these battles had first emerged, in fact, during the military preparations for them. Both 'Alī and his opponents had difficulties convincing some of their followers why they should fight with their "Muslim brothers." 'Alī often resorted to his political legitimacy and his "Wilāyah" in his exhortation of his doubtful followers. Mu'āwīyah ibn Abī Sufyān, on the other hand, employed his powerful propaganda machine to cast doubt on 'Alî’s adherence to Islam. In fact, he succeeded in convincing many people in his stronghold, al-Shām, to believe that 'Alī was no longer a "true Muslim." Khawārij also claimed similar charges of Irtidād, or leaving the religion, against ‘Alī. Both Mu‘āwīyah ibn Abī Sufyān's and Khawārij’s solutions

show the difficulty of justifying wars between two groups of Muslims according to Sunn̄̄ Islam.

To Shī'ah Muslims, the situation appeared much more clear. Not only was 'Alī the first Shī'ah Imām and, according to Shī'ah beliefs, the most prominent disciple of the Prophet, but also he was the "bearer of the sacred Wilāyah and Walāyah." Any war against such a man was by definition illegitimate regardless of who had fought it. As a result, Shī'ah Muslims had no theological hesitation in believing that the battles of 'Alī were true Jihāds. They also praised and venerated those companions of 'Alī killed in the battlefields as martyrs. The above perspective divorced the Shì'ī understanding of Jihād from the mainstream Sunnī perception. For a war to be called Jihād, it was no longer

\footnotetext{
356 'Alī's wars during his caliphate and their implications for Shī'ī strategic cultures, especially in terms of the Shī'i doctrine of Taqīyyah and political prudence, will be discussed in some more detail in the following Chapter under the subtitle "Principled Action and Expediency: The Legacy of "Alī."
} 
necessary for one side to consist of "infidels." Two groups of Muslims can indeed engage in Jihād, according to Shī'ah history, and only one side may end up in martyrdom. ${ }^{357}$ In such cases, one group is believed to be the followers of "the Truth," while the other side is believed to be either hypocrite or ignorant. Not surprisingly, the criteria for adherence to "the Truth" in the Shī'i interpretation have been developed around the notions of Wilāyah and Walāyah. In the resulting discourse of Jihād in Shī'ah Islam, the notion of "just war" was tied to the supreme principle of Divine Justice -instead of nominal adherence to Islam. Justice, as will be discussed in Chapter $\mathrm{V}$, is at the core of the sacred hierarchies of Wilāyah and Walāyah in Shī‘ah Islam. ${ }^{358}$ According to Shī‘̄i discourses, any war waged by Muslims in the cause of justice may be deemed a Jihād in the true sense of the term regardless of the religious status of the opposing side. ${ }^{359}$

The shift in the paradigm of Jihād in Shī'ah Islam was, in fact, a manifestation of a central theological feature of Shī'ah Islam, namely the doctrinal version of the Divine

\footnotetext{
${ }^{357}$ Note that in Sunnī Islam, the notion of war between two groups of Muslims was developed later on. Articulating from a majority position, however, Sunnī jurisdiction discusses the notion of Ahl al-Baghy, i.e. rebels, in this regard. The notion refers to a group of Muslims who rise against a legitimate caliph or sultan. According to mainstream Sunnī jurisdiction, it is the duty of Muslims to fight against Ahl al-Baghy; although the war with them is usually called Qitāl, i.e. war, and not Jihād. Note the contrast between minority Shī'ahs' point of emphasis on "justice" -and hence the legitimacy of rising against an "unjust rule"- on the one hand and the majority Sunnīs' point of emphasis on legitimate rulers and the prohibition of challenging such a rule on the other. See, for instance, Imām al-Shāfíīi, Kitāb al-Umm, Vol. 4, pp. 170251 -see pp. 226-238 in particular.

${ }^{358}$ One of the important contributions to Shī'ah Studies in general and the study of justice and spirituality in Shī'ah Islam in particular is Lakhani, M. Ali. (2006). The Sacred Foundations of Justice in Islam: The Teachings of 'Ali ibn Abi Talib. Bloomington: World Wisdom. Reza Shah-Kazemi's essay on "A Sacred Conception of Justice: Imam 'Ali's Letter to Malik al-Ashtar" (Ibid. pp. 61-108) is of particular relevance.

${ }^{359}$ Shī $^{\prime} \overline{1}$ discourses sometimes refer to one of the verses of the Qur'ān regarding Jihād, i.e. verse 2:193, in this matter. The verse does not mention "infidels" as the targets of Jihād. Instead, it describes them as alZālimīn, i.e. those who commit injustice. The verse is particularly significant for it has been referred to by the prominent Sunnī jurist, Muhammad ibn Idrīs al-Shāfi' 'ī, to justify "offensive Jihād against infidels." See below.
} 
Justice. Similar to Sunn̄̄ Mu'tazilīs ${ }^{360}$, Shī'ah theologians emphasized the absolute justness of God. They viewed the principle of justice as the fundamental moral principle from which other moral virtues were derived. The reverence for the principle of justice in Shī'ah theology was accompanied by an acute sensitivity to social justice among the

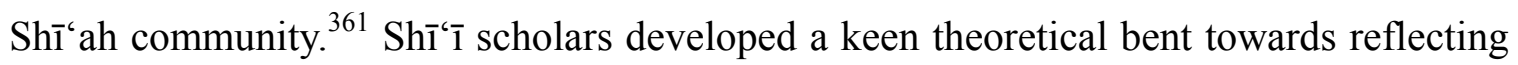
upon justice and injustice. They further established the theological and political emphasis on justice by quoting a Hadīth by the Prophet according to which "a state may survive with infidelity, but [it] would not survive with injustice." 362 Meanwhile, the scrupulous character of "Alī and his rule as the caliph consolidated the central place of justice in Shī'ah theological edifice. Venerated as the "Imām of Justice," or Imām al-'Adl, 'Alī has

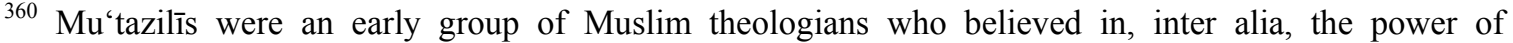
reasoning in interpreting the Qur'ān. They also preached "moral essentialism." The Mu'tazili School was the dominant school of theology in the Sunnī world until about the tenth century when the rivaling Ash 'arī School marginalized them. The Ash'arī School advocated a closer adherence to the literal meaning of the sacred Text, believed in a more limited role for human reasoning faculty and understood moral rules within -and dependent upon- the teachings of religion [see Frank, Richard M. (2006). Early Islamic Theology: The Mu'tazilites and al-Ash'ari. Texts and Studies on the Development of History of Kaläm. Aldershot: Ashgate Publications; and Martin, R. C., Woodward, M. R., \& Atmaja, D. S. (1997). Defenders of Reason in Islam: Mu 'tazilism from Medieval School to Modern Symbol. Oxford: Oneworld Publications. Part I provides some useful historical information about Classical Mu'tazilī. See also Abū al-Fatḥ Shahristānī, alMilal wal-Nihal, Vol. 1, pp. 43-84].
}

${ }^{361}$ The Qur'ân and the tradition of the Prophet offered the theological platform for this peculiar attention to the notion of social justice. This, of course, does not mean that the questions of social and Divine Justice did not appear in Sunnī theology. These questions, however, obtained a prominent role within Shì‘̄i Kalām, or theology. For an extensive discussion, see Muțahharī, Murtaḍā, (2009). 'Adl Ilāhī. Tehran: Șadrā Publications.

362 "Al-mulk yabqā ma 'a al-kufr, wa lā yabqā ma 'a al-zulm" is the famous Hadīth reported in both Shì'ī and Sunnī sources. See, for instance, Shaykh al-Mufîd, Kitäb al-Amāli, p. 310. Given the strong emphasis on justice, those Shī'i jurists who supported the political legitimacy of the rulers did so by arguing that these rulers were "just rulers." In comparison, some of the Sunnī jurists have argued -in a rather Hobbesian waythat the foundation of political legitimacy is in the provision of security and order by state. For an extensive discussion of political legitimacy in Islām, see Feirahi, Davoud. (2009). Qudrat, Dānish wa Mashrū ‘̀yat dar Islām. Tehran: Nashr Niy. Note that the issues of Kufr, i.e. disbelief, and Zulm, i.e. injustice or tyranny, relates to the notions Haqq Allāh, or "duties towards God," and Ḥaqq al-Nās, or "duties towards fellow human beings," in Shī'ah theology and Shī'ah jurisprudence. See Kadivar, Mohesn. (2008). Haqq al-Nās: Islām wa Huqūq Bashar. Tehran: Kawīr Publications. 
become the icon of justice in Shī' ${ }^{`}$ discourses. ${ }^{363}$ His actions have often been considered by Shī'ah Muslims as examples of just deeds, and his wars, of course, as examples of just wars.

The final turn in the Shī's formulation of Jihād took place in Karbalā. The Shī‘ $\overline{1}$ narration of the events emphasizes the "utter injustice" that was inflicted upon the "House of the Prophet." The battle was interpreted, inter alia, as one between the Truth, which is associated with Justice in the Qur' $a^{364}$, and falsehood. It was a legitimate Jihād against persecution and injustices. The event, therefore, sealed the essential character of Jihād in Shī'ah Islam. The Battle of Karbalā in Shī's̄ strategic cultures, it must be noted, is considered Jihād par excellence. As such, it weakened the association of Jihād in its Shī' $\overline{1}$ formulation with the "spread of Islam." 365 The above approach to Jihād was cogently summarized in one of the well-known Shī's traditions. According to this tradition, the Prophet has said that "[t]he most commendable of all Jihāds is [preaching] the word of justice at the presence of an unjust ruler." ${ }^{366}$ In parallel to this turn of emphasis to justice, Shī'ah eschatology emerged around the same notion. The coming of Muhammad al-Mahdī, the Shī'ah twelfth Imām, is believed to usher in an era of justice in the world. The prophesied battles of Muhammad al-Mahdī have been projected to be

\footnotetext{
${ }^{363}$ See Lakhani, M. Ali. The Sacred Foundations of Justice in Islam.

${ }^{364}$ See the verses 6:115, 16:76, and 31:13 in the Qur'ān.

${ }^{365}$ It is not, therefore, unexpected that Shī'ah rulers have easily invoked the metaphor of Husayn's martyrdom in their wars with neighboring Muslim countries. In pre-modern era, Shāh Ismā̄īl (d. 1524 C.E.) of the Safavid dynasty employed the imagery of Karbalā during the Battle of Chāldurān (1514 C.E.) against the Ottoman Empire. In modern times, Ayatollah Khomeini used this imagery during the Iran-Iraq War (1980-8). In neither case, the Shī'ah leaders faced major difficulties in calling their wars with fellow Muslims Jihād.

366 See Muhammad al-Riyshahrī, Mīzān al-Hikmah, Vol. 3, pp. 1943-4, Hadīth No. 2690; and also Ayatollah Muntaẓirī, Dìrāsāt fì Wilāyah al-Faqīh wal-Fiqh al-Dawlah al-Islāmīyyah, Vol. 2, p. 245.
} 
about the "spread of justice." "367

The triangle of Husayn's martyrdom, Jihād, and justice offered a unique paradigm for the Shī'ah community. In fact, one of the frequently quoted phrases in $S^{-} \bar{i}^{`} \overline{1}$ popular culture declares that "every day is "Āshūrā, every land is Karbalā." 368 An underlying assumption of this popular phrase was the atemporal and aspatial nature of what happened in Karbalā. Husayn's "fight against injustice"369 was venerated as a sacred ideal and a supreme example of man's inherent desire for justice. As discussed before, the veneration of Husayn has not been generally translated into the notion that Shī'ah Muslims should follow the example of their martyred Imām. Yet, combined with Shī‘ah eschatology, the events of Karbalā led to the emergence of a Shì'‘̄ "philosophy of history" built around the notion of justice and its eventual triumph. As Shī'ah Muslims rose to power in the Safavid Persia and the minority became the majority, the flavor of this metaphor gradually changed. While the pre-Safavid emphasis was on Husayn's victimization, the new discourses became more assertive culminating in modern

\footnotetext{
${ }^{367}$ A brief discussion of Shī'ah eschatology in relation to Shī`i strategic cultures will follow at the end of Chapter V.
}

368 "Kullu yawmin 'Āshūrā, kullu arḍin Karbalā." As mentioned before, however, Shī'ah Muslims generally did not interpret this phrase as a prescription to rebel against unjust rulers whenever the opportunity presented itself. The mainstream approach has been more cautious and sensitive to practical concerns. Even the Shī'ah Imāms who followed Husayn generally refrained from radical political actions. The above phrase, therefore, was often treated as a description of an enduring social reality, namely that of widespread injustice committed against the minority Shī'ah community. Several Shī's traditions reinforced the exceptionality of Husayn's martyrdom in the battlefield. In addressing a fervent group of Muslims who were pressing him to declare Jihād, "Alī says "be patient [...] and do not move your swords following your ego [...] for one amongst you who dies in the bed having obtained the true knowledge of God, of his Prophet, and of Ahl al-Bayt, has passed away as a martyr" [see 'Alī ibn Abī Țālib, Nahj al-Baläghah, Sermon 190].

${ }^{369}$ A common epithet of Husayn among Shī'ah Muslims is al-Mazlūm, which means the "victim of injustice." For an interesting discussion of this word and its connotations, see Enayat, Hamid. Modern Islamic Political Thought. p. 183. 
"revisionist" narrations. In these modern narrations, Husayn emerged as one who had fought for justice and later on, during the Islamic Revolution of 1979 , for freedom. ${ }^{370}$ As

a result, the story of Husayn's martyrdom has turned into a powerful mixture of myth and epic in Shī‘ah collective consciousness.

While Shī' $\overline{1}$ discourses of Jihād with their emphasis on justice are markedly different from Sunn̄̄ understandings, there are more similarities between $\mathrm{Sh}^{\top}{ }^{`} \mathrm{ah}$ and Sunn̄̄ in terms of the legal aspects of Jihād. In fact, in several areas of jurisdiction, Shī'ah jurists seem to have generally followed their Sunnī counterparts in their legal rulings. In terms of Shī'ī fatwās related to Jihād, this situation has caused some inconsequential rulings. Most of the Sunn̄̄ rulings on Jihād concern wars between Muslims on the one

\footnotetext{
370 'Alī Sharī'tī (d. 1975), a gifted preacher, was particularly influential in formulating Ḥusayn's martyrdom in more "activist" and "volunteerist" terms prior to the Revolution. In fact, Sharī'tī may be considered as a prime example of a group of Muslim "activists" without any formal and traditional education in Shi'‘ah Islam who, through self-education, began to re-interpret Shī'ah theology and Shī'ah history. Sharī'tī believed that Husayn's decision to go to Küfah was a conscious decision rooted in a deep sense of social responsibility [see Sharī'tī, 'Alī. (2011). Husayn Wārith Ādam. Tehran: Qalam]. His formulation of Shahādah was also imbued with mystical notion of Divine unification through the act of martyrdom, for which Husayn was the "supreme role model." Sharī'tī argued that Husayn's martyrdom was not about winning a battle. Instead, Husayn succeeded by "sending a message through his martyrdom" to the next generations [Ibid.]. He also emphasized the role of Husayn's surviving sister, Zaynab bint "Alī, in "propagating the message of Karbalā." In addition, Sharī'tī dismissed the traditional Sh'̄'̄i understanding of Taqīyyah as strategies of expediency. He reinterpreted Taqīyyah as either "Taqīyyah Waḥdat," i.e. Taqīyyah aimed at strengthening unity among Muslims, or "Taqīyyah Mubārizih," i.e. tactics of concealment for those who struggle against injustice. He claimed that Taqīyyah Mubārizih is not about protection of individual believers, but about protection of the Shī's "belief system" itself [see Sharī'tī, "Alī. (2011). Tashayyu' 'Alawī, Tashayyu' Șafawī. Tehran: Sipīdih Bāwarān]. As such, Sharī'tī saw Taqīyyah as a practical tactic for "activists" in their "never-ending struggle against unjust rulers." To Sharī'tî, history of mankind was the continuation of the archetypical rivalry between Abel and Cain, or the forces of good and evil. The evil was also associated with socioeconomic injustice, discriminations, and property ownership in Sharī'tî̀'s discourse [see Sharī'tī, 'Alī. (2008). Islām Shināsī. Tehran: Ilhām]. It was within such a blackand-white philosophy of history that Sharī'tī re-conceptualized quite a number of Shī'ī notions such as Shahādah and Taqīyyah. These reinterpretations often diverged from the traditional Shī'ī theological discourses, especially on Taqiyyah [see the following Chapter]. Nevertheless, his formulations of Shahādah and Taqiyyah became influential during the Revolution and even informed the discourses of some of the Shī'ah "Ulamā on the subjects. For more discussion of this "revisionist" understanding of martyrdom see Enayat, Hamid. Modern Islamic Political Thought. pp. 190-4. Enayat argues that in this modern discourse, martyrdom was transformed from a "passive and harmless" doctrine to a "rhetorical instrument of political mobilisation" [Ibid. p. 184].
} 
hand and non-Muslims on the other. The rulings are not unexpected as the majority of the military encounters of Sunn̄̄ Muslims were against non-believers along the expanding borders of the Muslim world. For the most part of Shī'ah history, such encounters were irrelevant to the Shī'ah community; for they were a small minority group living among Sunn̄̄ Muslims and they rarely shared a border with non-Muslims. The Battle of Karbalā, in which a small fringe group of Muslims were surrounded by a large Muslim army, is a reminder of this fact. Yet, Shī'ah jurists followed the lead of their Sunnī colleagues in writing extensively about "Jihād with infidels." 371 Such encounters with "infidels" did occur for Shī'ah Muslims. But they were far fewer and occurred much later. ${ }^{372}$ Not surprisingly, in these wars with the "infidels," the general Muslim discourse of Jihād proved to be a powerful mobilizing force. ${ }^{373}$

As suggested before, however, there is a distinct element in Shī' $\overline{1}$ jurisdiction of Jihād compared to the Sunnī discourses. For a war to be considered Jihād, there should be

\footnotetext{
${ }^{371}$ One of the clear examples of this rather Sunnī articulation can be find in the writings of Muhammad Hasan al-Najafĩ (Șāhib al-Jawāhir), the prominent Shī'ah jurist of the nineteenth century. Arguably neglecting the tradition of the Shī'ah Imāms - Alī and Husayn- and their "Jihāds" against "unjust" Muslims, he argues that Jihād signifies war against disbelievers with the purpose of spreading Islam [see Muhammad Ḥasan al-Najafī, Jawāhir al-Kalām fì Sharh Sharāyi 'al-Islām, Vol. 21, p. 3].

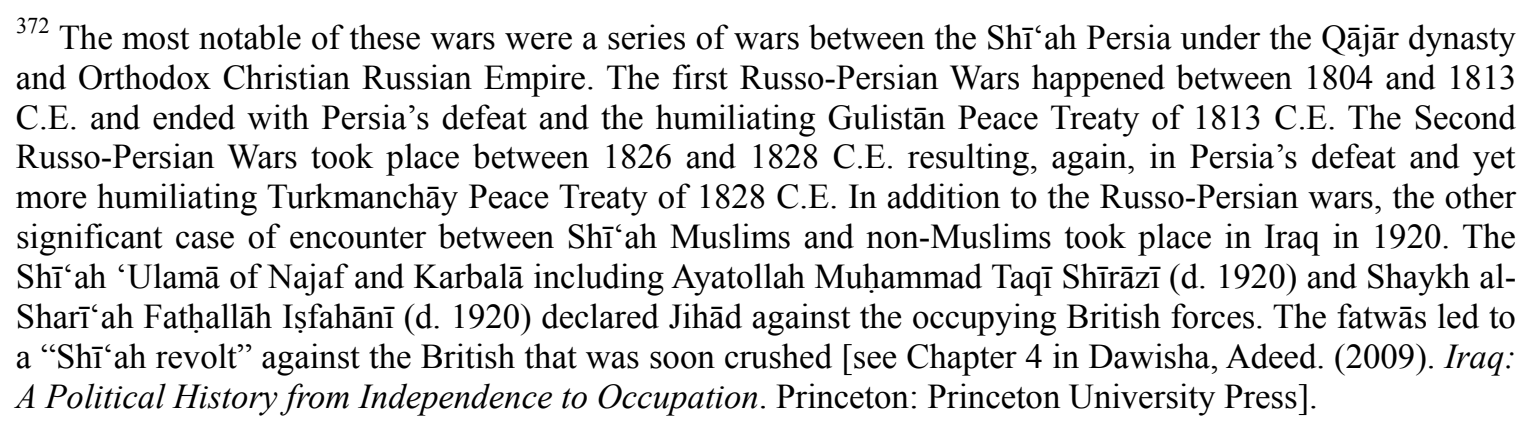

${ }^{373}$ Prominent Shī'ah jurists of the time including Shaykh Ja ‘far Kāshif al-Ghițā’ and Mullā Aḥmad Narāqī (d. 1829 C.E.) issued fatwās and declared the coming wars with Russian Empire as -defensive- Jihād. In fact, it was due to the insistence and religious exhortation of some of these prominent Shī ah jurists that Fath 'Alī Shāh of the Qājār dynasty reluctantly agreed to engage in the second round of wars with the Russian Empire in 1826 C.E.
} 
a "bearer of Wilāyah" present. Faghfoory discusses the various rulings of Shī'ah jurists

when it comes to Jihād. ${ }^{374}$ According to him, the majority of Shī'ah jurists believe that "offensive Jihād" is only possible when the Prophet or an "infallible" Shī'ah Imām is present. $^{375}$ As for the "defensive Jihād," nearly all Shī'ah jurists allow it with the permission of a qualified jurist. In other words, a qualified Shī'ah jurist may call a defensive war Jihād by issuing a fatwā. Secular authorities including the kings could not declare their wars as Jihād. Faghfoory also claims that those Shī‘ah jurists who have condoned "offensive Jihād"376 were under the influence of their Sunnī counterparts and particularly the writings of Muhammad ibn Idrīs al-Shāfi ‘ $\overline{1}^{377}$. Imām al-Shāfi ‘’’’s influence

${ }^{374}$ See Faghfoory, Mohammad H. Ethic of War and Peace in Shi' ite Islam.

${ }^{375}$ Faghfoory quotes Murtaḍa Muțahharī (d. 1979), one of the prominent and influential Shī'ah scholars of the past century, who categorically rejects "offensive wars" as "evil and illegitimate" [see Ibid. and Muṭahharī, Murtaḍā, (1998). Jihād. Tehran: Șadrā Publications. p. 43]. Muțahharī also rejects the notion of "spreading Islam through Jihād" as self-contradictory. According to his perspective, there is no such a thing as "offensive Jihād" for Jihād is by definition legitimate while "offensive wars" cannot be so.

${ }^{376}$ These include Shaykh al-Ṭūsī, 'Allāmih Ḥillī, Shahīd al-Thānī, Șāhịib al-Jawāhir, and Sayyid al-Khū'ī (d. 1992) [see for instance Shaykh al-Țūsī, al-Tibyān fì Tafsìr al-Qur' ān, Vol. 5, p. 202-3; Amīn al-Islām Țabarsī, Majma 'al-Bayān, Vol. 5, pp. 39-40; and Muḥammad Ḥasan al-Najafì, Jawāhir al-Kalām fì Sharh Sharāyi 'al-Islām, Vol. 21, p. 4]. It must be mentioned, however, that Șāhib al-Jawāhir's position regarding "offensive Jihād" has not been clearly stated. It seems that he accepts the possibility of challenging the Sh'̄'i consensus -i.e. the consensus about the impermissibility of "offensive Jihād" in the absence of the Imām. He does not, however, further elaborate on this matter. It must be also noted that, despite his above position, 'Allāmih Hillī is considered as one of the Shī'ah jurists who believe in centrality of peace and exceptionality of war [see Faghfoory, Mohammad H. Ethic of War and Peace in Shi' ite Islam].

Sunnī jurists who have argued for the possibility of "offensive Jihād" often refer to a controversial Ḥadīth attributed to the Prophet. As Faghfoory points out, Shī'ah jurists have questioned the authenticity of this Hadith by doubting the trustworthiness of its chain of transmitters. Instead, the above Shi' ${ }^{\prime}$ ah jurists use one Hadīth by Ja 'far ibn Muhammad, the sixth Shī'ah Imām, to establish their argument regarding "offensive Jihād" [see Ibid.; and al-Ḥurr al- 'Āmilī, Wasā’il al-Shī'ah fì Tahṣ̂̄l al-Masā'il al-Sharī'ah. Vol. 15, pp. 34$56]$.

${ }^{377}$ Known as Imām al-Shāfi ${ }^{`} 1$ (d. 820 C.E.), Muhammad ibn Idrīs is one of the most prominent Sunnī jurists and the founder of the Shăfi'i ${ }^{\prime}$ School of jurisprudence, one of the four mainstream Sunnī legal Schools. The other three Schools of Fiqh in Sunnī Islam are the Hanafī, the Mālikī and the Hanbalī Schools.

Ni`matullāh Șāliḥ̄i Najafābādī, a prominent Shī'ah scholar and theologian, argues in his Jihād dar Islām, or 
is particularly evident, Faghfoory argues, when it comes to Shaykh al-Ṭūsī’s position on Jihād. ${ }^{378}$ It has been argued that Imām al-Shāfi'‘̄̄'s consequential stance regarding "offensive Jihād" was rooted in the sociopolitical context of his time and the need of the powerful Abbasid empire to religiously justify its rapid territorial expansion. ${ }^{379}$ In this era of Muslim conquests, few Sunnī jurists questioned the legitimacy of such territorial expansions. Those Prophetic traditions ${ }^{380}$ that might have restricted or slowed down these

"Jihād in Islam," that most of the Sunnī and Shī'ah jurists who have accepted the possibility of "offensive Jihād" have been under the influence of Imām al-Shāfi'i and his rather extreme interpretation of the verse 2:193 of the Qur'ān in his famous book [see Kitāb al-Umm, Vol. 6, p. 38]. Although several Mālikī and Hanbalī jurists have accepted Imām al-Shāfi ‘'ìs stance regarding Jihād, his interpretation has not remained unchallenged. Ibn Jarīr al-Tabarī, the prominent Sunnī commentator on the Qur'ān, is among those who have rejected Imām al-Shāfi ‘'s's interpretation of the verse 2:193 [see Faghfoory, Mohammad H. Ethic of War and Peace in Shi 'ite Islam; and Șāliḥ̄ Najafābādī, Ni'matullāh. (2008). Jihād dar Islām. Tehran: Nashr Niy].

${ }^{378}$ See Faghfoory, Mohammad H. Ethic of War and Peace in Shi' ite Islam; and Shaykh al-Ṭūsī, al-Nihāyah fì Mujarrad al-Fiqh wal-Fatwā, pp. 289-93. As noted by Faghfoory, several other early jurists of Hillī origin followed Shaykh al-Ṭūsī’s position on "offensive Jihād." These include Aḥmad ibn Idrīs Hillī (d. 1202 C.E.) [see in particular his al-Sarā'ir al-Hāà li-Tahrīir al-Fatāwì, Vol. 2, pp. 3-19] and "Allāmih Hịillī.

379 See Faghfoory, Mohammad H. Ethic of War and Peace in Shi`ite Islam; and Ni‘matullāh Ṣāliḥ̄ Najafābādī, Jihād dar Islām.

${ }^{380}$ Generally speaking, Muslim jus in bello and jus ad bellum contain some of the generic ethics-of-war items such as protection of civilians and the environment as well as the laws of proportionality. There are several obligations in regards to declaration of war, sending warnings, and giving ultimatums [see Faghfoory, Mohammad H. Ethic of War and Peace in Shi'ite Islam; and Muhammad Hasan al-Najafĩ, Jawāhir al-Kalām fì Sharh Sharāyi 'al-Islām, Vol. 21, pp. 51-4]. There are certain prohibitions against cutting trees, destroying farms and villages, killing animals, polluting rivers, cursing the enemy, catapulting fireballs, and flooding the enemy as well as strong prohibitions against poisoning enemy's drinking waters [see 'Allāmih Majlisī, Bihāar al-Anwārr, Vol. 32, p. 399; Ibid. Vol. 19, p. 179; al-Najafī, Jawāhir al-Kalām fì Sharh Sharāyi 'al-Islām, Vol. 21, pp. 66-8; Abū al-Majd al-Ḥalab̄̄, Ishārat al-Sabaq, pp. 142-3; 'Allāmih Hillī, Tadhkirah al-Fuqahā', Vol. 1, p. 413 (Maktabah al-Murtaḍawìyyah's edition); and Quṭb al-Dīn alBiyhaqī, Ișbāhh al-Shī'ah bi Mișbāhh al-Sharī'ah, pp. 187-9]. Insulting the enemy's dead and mutilation are forbidden [see Abū Șalāh al-Ḥalabī, al-Kāfì fìl-Fiqh, pp. 255-7; and al-Najafî, Jawāhir al-Kalām fì Sharh Sharāyi 'al-Isläm, Vol. 21, pp. 77-8]. Fighting is prohibited in sacred places such as the vicinity of Ka'bah as well as during four sacred months of Muslim calendar [see al-Najafì, Jawāhir al-Kalām fì Sharh Sharāyi 'al-Isläm, Vol. 21, pp. 32-4]. Killing of women, children, the elderly, the disabled, and the blind are generally prohibited [see al-Najafî, Jawāhir al-Kalām fì Sharh Sharāyi 'al-Islām, Vol. 21, p. 68; and Ibid. pp. Vol. 21, 73-7]. There are also some strong prohibitions against killing scholars, monks, and residents of monasteries and nunneries [see Muhammad ibn Jarīr al-Ṭabarī, Tārìkh al-Ṭabarī, Vol. 2, pp. 131-385; 'Allāmih Majlisī, Biḥ̄ar al-Anwār, Vol. 21, p. 60; al-Najafî, Jawāhir al-Kalām fì Sharh Sharāyi 'al-Islām, Vol. 21, p. 76; and 'Allāmih Ḥillī, Tadhkirah al-Fuqahā', Vol. 1, p. 412 (Maktabah al-Murtaḍawīyyah's 
expansions were also overlooked.

Unlike Imām al-Shāfi'‘̄, however, the Shī'ah Imāms who lived during the Umayyad and Abbasid expansions did not accept the legitimacy of their rule, let alone sanctioning their wars as Jihād. Therefore, even the Shī'ah jurists who have condoned the possibility of "offensive Jihād" accept the Shī'ah consensus. According to this juridical consensus, for an "offensive Jihād" to be legitimate, the permission of an "infallible Imām" is necessary. ${ }^{381}$ In Shī'ah history, however, there exists a precedent that renders “offensive Jihād” relatively problematic. According to Shī's̄ historiographies, "Alī did not allow his army to initiate war. ${ }^{382}$ It might be due to such precedents that scholars such as Murtaḍā Muṭahharī have identified Jihād with “defensive wars., „383

Finally, it is worth visiting the often-mentioned division between Dār al-Harb, i.e. the Abode of War, and Dār al-Islām, i.e. the Abode of Islam, when it comes to studying edition)] although the legal details on all the above items vary from one jurist to another.

${ }^{381}$ See Muhaqqiq Hiillī, Sharāyi ' al-Islām fì Masā’ il al-Halāl wal-Harām, Vol. 1, p. 232; Ibn Idrīs Hiillī, alSarā'ir al-Hāà li Tahrīr al-Fatāwì, Vol. 2, p. 25; and Muḥammad Hasan al-Najafì, Jawāhir al-Kalām fì Sharh Sharayyi 'al-Isläm, Vol. 21, pp. 11-14. The only exception to this juridical consensus is a number of contemporary Shī'ah jurists. They have argued that not only "offensive Jihād" is possible, but also it could be undertaken by the permission of a qualified jurist. The most significant Shī'ah jurist who has taken this position is Ayatollah Sayyid Abū al-Qāsim al-Khū'̄i [see al-Mīrzā Jawād al-Tabrīzì, Sirāạt al-Nijāt fì Ajwibah al-Istiftā'āt, Vol. 3, p. 359]. Ayatollah Khomeini's position on this issue seems less clear. In his earlier works such as Tahrīr al-Wasīlah, he argues that "offensive Jihād" lies within the religious authority of the "infallible Imāms"; and his emphasis is clearly on defense and resistance. Towards the end of his life and in his position as the Supreme Leader of the Islamic Republic in Iran, however, Ayatollah Khomeini seemed to have adopted a position that viewed the authority of a qualified jurist identical to that of the "infallible Imāms" [see Ayatollah Khomeini, Șahĭfih Nūr, Vol. 20, p. 451-2. Retrieved from www.tebyan.net on January 23, 2012].

${ }^{382}$ See, for instance, Nașr ibn Muzāḥim al-Minqarī, Waqa 'ah Șiffin, p. 153; and 'Alī ibn Abī-Ṭālib, Nahj alBaläghah, Letter 14 according to which 'Alī explicitly forbids initiation of war.

${ }^{383}$ See Muṭahharī, Murtaḍā. Jihād. p. 39. In his argument, Muțahharī specifically refers to the verses 22:3940 of the Qur'ān. In addition to Muțahharī, Faghfoory refers to Ayatollah Șāliḥ̣i Najafābādī as well as Ayatollah Muhaqqiq Dāmād as prominent Shī'ah jurists who categorically reject "offensive Jihād" [see Faghfoory, Mohammad H. Ethic of War and Peace in Shi'ite Islam]. 
Jihād in Islam. The two terms appeared in Sunnī legal discourses due to the expansion of -Sunn̄̄- Islam during the Umayyad and Abbasid empires. Some of the Shī'ah jurists then followed their Sunnī predecessors in employing these and several similar terms. Yet, the reduction of the complex legal system of Sunnī Muslims -in regards to non-Muslims- to Dār al-Ḥarb and Dār al-Islām seems unwarranted. In fact, depending on the political conditions of the time, Sunnī jurists devised a spectrum of concepts such as Dār alHudnih, i.e. the Abode of Truce, Dār al-Ṣulḥ, i.e. the Abode of Peace, Dār al-Amn, i.e. the Abode of Safety, and Dār al-Da'wah, i.e. the Abode of Invitation or Calling. ${ }^{384}$ For each of these "Abodes," they developed various rulings that differed from one jurist to another. The diverse legal rulings highlight the complexities inherent in Sunnī and Shī'ah legal systems when it comes to the issues such as war, peace, Jihād as well as the treatments of different groups of non-Muslims during and after wars. ${ }^{385}$

\footnotetext{
${ }^{384}$ Ibid.

${ }^{385}$ Before concluding this Chapter, it is worth briefly reviewing the issue of suicide and surprise attacks. Suicide attacks, properly speaking, are a modern phenomenon. These attacks are technically possible only because of the modern advancements in explosive technologies. In the pre-modern world, there existed the notion of surprise attacks with the attacker risking certain death in the course of the assault. Yet, the attacker would not kill himself. For this rather evident technical reason, there is nothing in Shi' $1 \overline{1}$ theological sources that directly engages the issue of suicide attacks and its permissibility. There is, as discussed before, the categorical rejection of committing suicide in the Qur'ān [2:195]. There is also the verse 5:32, which declares murdering another human being unjustly is as if "one kills the whole of humanity." Those modern jurists who are against committing suicide attacks generally base their arguments upon these two verses. They also refer to a variety of traditions attributed to the Prophet and the Shī'ah Imāms against "surprise attacks." The frequently quoted of these traditions is a Hadith by Ja far ibn Muhammad, the sixth Shī'ah Imām, who reports that the Prophet never conducted "surprise night assaults" against his enemies [see Abū Ja'far Thiqat al-Islām Kuliynī, Usūul al-Kāfí, Vol. 5, pp. 27-8; Shaykh al-Ṭūsī, al-Nihāyah fì Mujarrad al-Fiqh wal-Fatwā, p. 298; and 'Allāmih Majlisī, Bihār al-Anwār, Vol. 19, p. 167]. In another report attributed to Ja 'far ibn Muhammad, it is claimed that "Islam rejects Fitk" [see "Allāmih Majlisī, Bihār al-Anwār, Vol. 47, p. 137; Shaykh Hādī al-Najafī, Mūsū 'ah Ahādīth Ahl al-Bayt, Vol. 2, p. 47; and Ibid. Vol. 8, p. 280]. In classical Arabic, Fitk means killing someone off-guard or attacking someone by surprise [see Muhammad ibn Manẓūr, Lisān al- 'Arab]. There is also a general prohibition against "surprise attacks" attributed to the Prophet himself [see Muḥammad Ḥasan al-Najafì, Jawāhir al-Kalām fì Sharh Sharāyi 'al-Isläm, Vol. 21, p. 82]. Finally, there is the tradition of 'Ali in the Battles of Jamal, Siffin, and Nahrawān who rejected surprise night attacks against the enemy [see Nașr ibn Muzāhịim al-Minqarī, Waqa'ah Siffin, pp. 193-225].
} 


\section{CHAPTER IV}

\section{TAQĪYYAH: STRATEGIES OF EXPEDIENCY}

\section{Introduction}

The violent events in Karbalā bolstered the place of Shahādah and the metaphor of an "ideal death" in Shī'ah theology. Yet, the implications of the killing of the Prophet's grandson proved to be more complicated. As discussed before, the majority of Shī'ah jurists began to view Husayn's final decisions and his martyrdom as exceptional; ${ }^{386}$ and so did the majority of the Shī'ah community. The fact that Husayn's dramatic fate was not paralleled with that of any other Shī'ah Imām further established the notion that Karbalā was an extraordinary page in Shī'ah history. Husayn's martyrdom, in other words, was believed to be the result of "the gravest of conditions." At the same time, the naked vulnerability of the Shī'ah community, so radically illustrated in Karbalā, called for urgent measures in order to guarantee the survival of the community. The Shī ${ }^{\text {'ah }}$ Imāms and, later on, the Shī' ${ }^{`}$ ah jurists understood the implications of Karbalā well. They tried, therefore, to strike a balance between the rather "idealistic" messages of the story of Husayn on the one hand and the growing, pragmatic, concerns on the other. Following

Based on the above traditions, some Shī'ah jurists have rejected suicide attacks, for they both entail the forbidden act of committing suicide; and there is an element of surprise embedded within them. Arguably the most prominent Shī'ah jurist in our time who has ruled against the practice and, in a number of interviews, has called it an "act of terrorism" is Ayatollah Yūsuf Șāni'î [retrieved from www.saanei.org on February 29, 2012]. It must be also noted that traditional Shī'ah jurists have generally tended to be conservative in their social rulings. The roots of this conservativeness have been both theological and institutional. In terms of the issue of Qatl, or killing, some of these jurists have been extra cautious. Muhaqqiq al-Ardabīlī (d. 1585 C.E.), for instance, calls Qatl "a grave affair" that demands "the greatest caution" [see al-Sayyid al-Khānsārī, Jāmi ' al-Madārik, Vol. 7, p. 35]. According to Mohsen Kadivar, AbulFaụl Bahā’ al-Dīn Ișfahānī, also known as Fạ̣̄il Hindī (d. 1725 C.E.), goes as far to argue that legitimate killing is only possible with the permission of the "infallible Imām" [see Kadivar, Mohesn. Haqq al-Nās: Islām wa Huqūq Bashar. p. 181; and Fāḍil Hind̄̄, Kashf al-Lithām 'an Qawā 'id al-Ahkām].

${ }^{386}$ As discussed in the preceding Chapter, a number of modern Shī'ah jurists and scholars have disputed this mainstream interpretation, with Ayatollah Khomeini being the most influential among them. 
the examples of the Shī‘ah Imāms who succeeded Husayn, the early Shī'ah theologians managed to elaborate a complex juridical edifice. Their legal construct was an effort to accommodate both their ideals and the severity of the reality. A delicate and at times brittle combination of "principled action" and "pragmatism" was the result. The combination of these two dynamics was intended to provide Shī'ah Muslims with an aspiring drive to achieve "spiritual ideals" and, at the same time, to socialize them to heed constraints and limitations. It imparted, furthermore, a sense of "religious" respect for the protection of the Shī'ah community as well as that of individual Shī'ah Muslims. It must be reminded that this combination was due to the strategic assessment of the early Shī'ah community's situation by the Shī'ah Imāms - especially the fourth, the fifth, and the sixth Imāms. The result was the sometimes misunderstood Shī's doctrine of Taqīyyah $^{387}$.

Before examining this doctrine, it must be noted that neither Shahādah nor Taqīyyah are central theological notions in Shī'ah Islam. ${ }^{388}$ Nevertheless, they appear to be the most important strategic notions in Shī'ah theology. Therefore, they have been particularly consequential in shaping $\operatorname{Sh}^{\mathbf{1}}{ }^{‘} \overline{1}$ strategic cultures. As will be discussed in the following Chapter however, both the doctrine of Shahādah and that of Taqiyyah rest upon a central Shī'ī theological notion, i.e. Wilāyah and Walāyah

\footnotetext{
387 The Arabic word Taqiyyah comes from the Arabic root w-q-y (i.e. (sوق). According to Wehr's ArabicEnglish Dictionary, $w-q-y$ means, inter alia, "to guard"; "to preserve"; "to shield"; "to be wary"; "to be on one's guard"; and "to fear." The term Taqiyyah does not appear in the Qur'ān. However, one of the key Qur'ānic terms, "Taqwā," comes from the same root. Taqwā means piety, virtue, and righteousness and its observance is among the major callings that the Qur'ān makes to its readers [see, for instance, 2:197; 5:2; $7: 26 ; 20: 132 ; 22: 37 ; 48: 26 ; 58: 9$ and 49:13 -or the "verse of diversity"- in the Qur'ān].

${ }^{388}$ Some of the central theological notions in Shī'ah Islam are the doctrine of Divine Unity, the principle of Prophethood, the principle of Afterlife and the Day of Judgement, the principle of Divine Justice, and the ontology of Wilāyah and Walāyah.
} 
Unlike Shahādah, the doctrine of Taqìyyah has not been extensively elaborated upon in Shī'ah Islam. Neither has it been visibly manifested in a particular episode in Shī'ah history as did Shahādah in Karbalā. Nevertheless, Taqīyyah has imbued Shī'̄̄ strategic cultures with a keen sense of prudence and expediency. It is not, therefore, surprising that among numerous minority groups that emerged throughout the Muslim world, Shī'ah Muslims have proved to be among the most viable and self-sufficient ones.

\section{The Foundations of Shī‘̄i Doctrine of Taqīyyah and Its Implications}

In his Modern Islamic Political Thought, Hamid Enayat has written a few pages on the notion of Taqiyyah. His approach is within the theoretical framework of political thought studies. However, given the importance and relevance of Enayat's analysis, it is worth beginning with a rather long quotation from his work. After reviewing the etymology of the word Taqīyyah, and its Arabic root, Enayat writes

"[t]here is thus nothing in the term [i.e. Taqiyyah] itself to justify its standard translation in English either as dissimulation or (expedient) concealment, although both acts may be necessary to guard oneself from physical or mental harm on account of holding a particular belief opposed to that held by the majority. The Shī'i case for the necessity of Taqiyyah is based on a commonsense 'counsel of caution' on the part of a persecuted minority. Since for the greater part of their history the Shī'is have been a minority amidst the global Islamic community and have lived mostly under regimes hostile to their creed, the only wise course for them to follow has been to avoid exposing themselves to the risk of extinction resulting from an open and defiant propagation of their beliefs, although they have not shunned their mission, whenever the opportunity has presented itself, to give a jolt to the Muslim conscience by revolting against impious rulers. This precautionary attitude has not been confined to the Shī'īs alone in Islamic history [...]. But the practice has come to be almost exclusively associated with Shī'issm, partly because of the enduring status of the Shì'îs in history as a minority, or 'unorthodox' group, and partly because their opponents have found in it valuable ammunition for their propaganda." (emphasis in the text) 
Enayat notes the strategic thinking that underlies the doctrine of Taqiyyah as well as the element of "common sense" embedded within it. The causal link between the minority status of Shī' ah Muslims and the emergence of this doctrine seems evident. ${ }^{389}$ Yet, Shī'ah jurists proactively strived to establish the religious foundation of Taqīyyah. The practice, these jurists maintained, had Qur'ānic roots. Several verses in the Qur'ān imply the permissibility of expediency and, more explicitly, that of prudent concealment. The most important among these is the verse 16:106. According to this verse, "[w]hoso disbelieves in God, after he has believed -excepting him who has been compelled, and his heart is still at rest in his belief- but whosoever's breast is expanded in unbelief, upon them shall rest anger from God, and there awaits them a mighty chastisement. ${ }^{390}$ The sixth Shī'ah Imām, Ja'far ibn Muhammad, is also reported to have related the famous verse 2:195 to the doctrine of Taqiyyah. As discussed before, this is the verse that rejects selfdestruction. Ja'far ibn Muhammad has been reported commenting upon the verse by arguing that it refers to the practice of Taqiyyah. ${ }^{391}$

\footnotetext{
${ }^{389}$ It must be mentioned that the notion of Taqīyyah also exists in Sunnī Islam -albeit with a different flavor; for, as Hamid Enayat reminds, there is a "commonsense" element in this notion that renders it unavoidable in any comprehensive system of life [see Ibid.].

${ }^{390}$ This is Arberry's translation. It has been reported that the verse was revealed during the early years of Islam and that it addresses 'Ammār ibn Yāsir, who was one of the earliest disciples of the Prophet. Under tortures at the hand of Meccan idol-worshipers, 'Ammār ibn Yāsir had rejected Islam by tongue while still a believer in heart. The verse is understood as God's absolving 'Ammār ibn Yāsir of guilt in doing so. Various Shī'ī and Sunnī commentaries on the Qur'ān have reported this historical context for the verse. See, for instance, Shaykh Makārim Shirāzī, Tafsīr Nimūnih; Amīn al-Islām Ṭabarsī, Majma 'al-Bayān; and 'Abd al-Raḥmān ibn Abī Bakr al-Suyūṭị, al-Durr al-Manthūr fìl-Tafsìr bil-Ma'thūr. In several traditions reported from the Shī'ah Imāms, the practice of Taqiyyah is justified by reference to this particular verse. See, for instance, al-Hurr al-'Āmilī, Wasā'il al-Shì 'ah fì Tahṣịl al-Masā'il al-Sharī'ah, Vol. 11, pp. 479-80.

${ }^{391}$ See Ibid. Vol. 11, p. 467.
} 
In addition to the Qur'ānic verses ${ }^{392}$, several traditions, or Hadīths, attributed to the Shī'ah Imāms further solidified the permissibility of cautionary acts of Taqīyyah. The overwhelming majority of these Hadīths comes from the sixth Shī'ah Imām. The large number of Hadīths by Ja'far ibn Muhammad is in part a result of the fact that he was exceptionally active in teaching his Shī'ah followers. In fact, the number of the Hadīths attributed to Ja'far ibn Muhammad is more than that of any other Shī'ah Imām. Yet, it is also reasonable to believe that the building social pressure had had something to do with the unusually large number of "Taqīyyah Hadīths" by him. During Ja"far ibn Muhammad's imamate, high expectations emerged among the Shī'ah community about the necessity of political engagement by their Imām. ${ }^{393}$ As a result, Ja'far ibn Muhammad seems to have had to justify his aloof approach in politics; and he did so through a number of teachings on Taqīyyah. Later on, these teachings constituted the "Hadith Foundation," or Dalā'il al-Rawā'̄̄, of the doctrine of Taqīyyah.

In several Hadīths, Ja'far ibn Muḥammad is reported to have commented upon the Qur'ānic verses 28:54 and 41:34 in which "good deeds" and "evil deeds" are compared. In his comments, he teaches his followers that "Taqiyyah is [what is referred in these verses as] the good deed while divulging [the secrets of the community] is an act of evil." 394 He then argues that the "best defense" for Shī'ah Muslims is to practice

\footnotetext{
${ }^{392}$ Other Qur'ānic verses that refer to the permissibility of expediency in general and that of Taqiyyah in particular are 3:28 and 40:28. Note that these Qur'ānic references have generally sparked a similar response among both Shī'ah and Sunnī commentators. The practical relevance of expediency and caution to Sh'`‘ ah Muslims, however, created more incentive for Shī ah jurists to elaborate upon the doctrine, its implications, as well as its limitations.

${ }^{393}$ For a more detailed discussion of the political context of Ja 'far ibn Muhammad's imamate, see below.

394 See Sayyid Hasan al-Bujnūrdī, al-Qawā'id al-Fiqhīyah, Vol. 5, p. 77; Abū Ja‘far Thiqat al-Islām Kuliynī, Ușūl al-Käfì, Vol. 2, pp. 217-8; and al-Ḥurr al-'Āmilī, Wasā'il al-Shī'ah fì Tahṣìl al-Masā'il al-
} 
Taqiyyah so that "the one whom between you and him is enmity [would turn around] as though he has been a devoted friend." ${ }^{, 35}$ In another commentary upon the Qur'ānic verses 18:94 and 18:95, Ja'far ibn Muhammad likens the practice of Taqīyyah to erecting a "strong barrier" between one and one's enemies. ${ }^{396}$ In several other traditions, he declares Taqiyyah to be the "protective screen," or Junnah, the "shield," or Turs, and the “sanctuary," or Hirz, for "the believers." ${ }^{, 397}$ He emphasizes that the practice of Taqiyyah is the tradition of his fathers, i.e. the previous Shī'ah Imāms, and that of the prophets. ${ }^{398}$ In parallel to these traditions, a number of Hadīths encouraged Shī'ah Muslims to be vigilantly discreet and to practice Kitmān, which implies secrecy, restraint, and

Sharī'ah, Vol. 11, pp. 459-61. Several other Hadīths include the Shī'ah Imāms' commentaries on verses such as $2: 83 ; 3: 200 ; 41: 34 ; 41: 35 ; 49: 13$; and 103:3; in which Taqiyyah is related to various acts including "speaking leniently to [non-Shī'ah] others," practicing "endurance," "winning over one's enemies," practicing "patience," observing "piety and righteousness," and "doing the righteous deeds" all in a spirit of expediency and caution [see Ibid. Vol. 11, p. 463; Ibid. Vol. 11, p. 466; Ibid. Vol. 11, p. 473; and "Allāmih Majlisī, Bihāar al-Anwār, Vol. 72, p. 401].

${ }^{395}$ See al-Ḥurr al-'Āmilī, Wasā'il al-Shì'ah fì Tahṣìl al-Masā'il al-Sharī'ah, Vol. 11, p. 461. The latter part of the above Hadīth contains a direct quotation from the verse 41:34 of the Qur'ān [consulted with Yūsuf 'Alī's translation].

${ }^{396}$ Ibid. Vol. 11, p. 467. Note that the socio-historical context of these teachings by Ja'far ibn Muhammad was the rising tendency within the Shī'ah community to become politically more assertive. Such course of actions would have entailed certain unrestrained public acts against which Ja'far ibn Muhammad adamantly argued. See Sayyid Ḥasan al-Bujnūrdī, al-Qawā 'id al-Fiqhīyah, Vol. 5, p. 77.

${ }^{397}$ See al-Hurr al- 'Āmilī, Wasā'il al-Shì'ah fì Tahṣ̂̀l al-Masā'il al-Sharī'ah, Vol. 11, pp. 460-61. Arguably, the most explicit affirmation of Taqiyyah appears in a short Hadith attributed -with slight differences- to various Shī‘ah Imāms including Ja ‘far ibn Muḥammad. The Ḥadīth declares that là dìna li man là taqùyyata $l a h \bar{u}$, which means "one who does not observe Taqiyyah has no religion" [see Ibid. Vol. 11, pp- 465-6; and Ibid. Vol. 11, p. 468].

${ }^{398}$ See Ibid. Vol. 11, p. 460; Ibid. Vol. 11, p. 463; Ibid. Vol. 11, p. 464; and also 'Allāmih Majlisī, Bihāar alAnwār, Vol. 75, p. 347. It is worth noting that, despite the explicit defense of Taqiyyah in these Hadīths, there is no Shī'i i tradition from the Imāms clearly and comprehensively defining what constitutes Taqiyyah. This might be an indication that, at the time, the Shī'ah community had a relatively clear, intuitive, understanding of what the notion of Taqīyyah implied. The Imāms, therefore, did not feel obliged to expound upon the definition of the notion; and they did not go beyond relating Taqiyyah to commonsense prudence, dissimulation, and discretion. 
discretion. ${ }^{399}$ In one Hadīth, the sixth Imām elaborates on the practice of Kitmān by encouraging the Shī'ah community to be "subtle" in their social interactions and to observe extreme care in following -and fulfilling- the Imām's wishes. ${ }^{400}$ These Hadiths unequivocally repudiated the act of Idhā'ah, or divulging the secrets [of the community]. ${ }^{401}$ The body of traditions, therefore, related the doctrine of Taqiyyah with the notions of Wilāyah and Walāyah, which constituted some of the central "Sacred Secrets" of the Shī'ah community. ${ }^{402}$ In a Hadīth attributed to the eighth Shī'ah Imām, the "secret" that must be protected against Idhā'ah is stated to be Wilāyah - which had been transferred from God to the Prophet and from him to the Shī'ah Imāms. ${ }^{403}$

One can infer from the above Shī's traditions that, from the beginning, the doctrine of Taqiyyah has had an esoteric aspect as well. The esoteric dimension went

\footnotetext{
${ }^{399}$ See, for instance, Abū Ja ‘far Thiqat al-Islām Kuliynī, Ușūl al-Kāfì, Vol. 2, pp. 221-5.

${ }^{400}$ See Ibid., Vol. 2, p. 223. The Imām uses the derivatives of the Arabic word Luṭf, which means subtlety and delicacy, in reference to the practice of Kitmān. In another Hadīth, he relates the practice of Taqīyyah to that of Kazm al-Ghayz, i.e. containing one's indignation, in front of one's enemy [see al-Hurr al- 'Âmilī, Wasā'il al-Shī'ah fì Taḥșill al-Masā'il al-Sharī'ah, Vol. 12, pp. 179-80].
}

${ }^{401}$ See, for instance, Ibid. Vol. 11, pp. 492-6. In the same body of Hadīths, the Shī'ah Imāms also warn their followers against divulging the Imāms' Amr. Here, Amr, which can loosely be translated into "affairs," might also refer to the extensive yet underground Shī'ah network that had emerged around the offices of the Imāms.

${ }^{402}$ During the imamate of the last eight Imāms, it seems that the protection of the Shī'ah "secrets," or alAsrār, had become a major issue in the community. Ja'afar ibn Muhammad, for instance, declares that protection of the Imām's Sirr, or secret, is the "Jihād of Shī'ah Muslims," and that divulging such a Sirr is nothing short of "intentionally killing" the Imām [see Ibid. Vol. 11, pp. 494-5].

The relation between Taqīyyah and Jihād is further elaborated upon in another Hadīth by the sixth Imām. In this Hadìth, Ja 'afar ibn Muḥammad says that the Jihād of Shī'ah Muslims against "God's enemies" is with "sword" under the auspices of a just ruler and with "Taqiyyah" under the reign of an unjust one [See Ibid. Vol. 11, p. 464].

${ }^{403}$ For this Hadīth, see Ibid. Vol. 11, p. 492. The sixth Shī‘ah Imām also confirms that "bearing," i.e. Ihtimāl, of the "heavy doctrine" of Wilāyah and Walāyah entails not only accepting its truth, but also protecting it from disclosure to any "unsuited audience" [see Ibid. Vol. 11, p. 484; and Abū Ja 'far Thiqat alIslām Kuliynī, Ușūl al-Kăfi, Vol. 2, pp. 222-3]. 
beyond the exoteric implications of the doctrine for the survival of the Shī'ah community. "Esotericism" of Taqīyyah may be approached in two different ways. First is related to the "esoteric teachings" of the Shī'ah Imāms and what such teachings entailed. Hamid Enayat elaborates upon this aspect elegantly. He writes

"[t]here is another argument in defence of taqiyyah which is mysticphilosophical, and is predicated on the esoteric character of Shī'īs [...]. If the raison d'être and the essential function of the Imāms should be sought in their status as the repository of the truth of the religion, or the 'sacred trust' $\left[{ }^{404}\right]$ placed exclusively at their disposal, then their knowledge of that truth cannot be communicable through propagation (idha' 'ah), otherwise [...] the knowledge itself will be in danger of being misrepresented and vulgarised." 405 (emphases in the text)

According to Enayat, the concern for the protection of the Bātinī, or inward, teachings of the Imāms was one of the reasons that led the Shī'ah community to be cautious and to practice Taqīyyah. Accompanying this outlook was the belief that Shī'ah Muslims would always be a minority in the Muslim world; for the "heavy burden of the Sacred Truth",406 would render it "unbearable" for the majority of mankind. The emergence of this belief was due to the esoteric nature of parts of the teachings of the Shī'ah Imāms. These teachings, early Shī'ah Muslims believed, were not meant to be disseminated to the larger

\footnotetext{
404 This "sacred trust" refers, inter alia, to the notion of "Divine Trust" as articulated in the Qur'ān, 7:172. See the preceding Chapter for some more discussion.

${ }^{405}$ Enayat, Hamid. Modern Islamic Political Thought. p. 176.

406 The notion of the "heavy burden of the Truth" is elaborated upon in some of the Hadiths attributed to the first Shī'ah Imām, 'Alī. See, for instance 'Alī ibn Abī Ṭālib, Nahj al-Balāghah, Letter 53; and Ibid. Hikmah 376. To further establish their assertion that there exists a correlation between Shī'ahs' minority status and the truth of their beliefs, Shī'ah authors have referred to several verses of the Qur'ān including 2:249; 4:66; $6: 119 ; 7: 17 ; 8: 34 ; 11: 40 ; 12: 106 ; 23: 70 ;$ and $34: 13$. Needless to say, these Qur'anic references provided early Shī'ah communities with the much-needed theological and spiritual comfort in coming in terms with their inferior social status.
} 
public. As a result, during the life of the eight Shī'ah Imāms who succeeded Husayn, a far-reaching, yet secret, network of Shī'ah Muslims emerged. The network effectively connected Shī'ah Muslims throughout the large and expanding Muslim territory to their Imāms in Medina, Baghdad, Khurāsān, or Sāmarrā. The teachings and instructions of the Imāms were disseminated through this network while it also made extensive financial transactions among Shī'ah Muslims possible. ${ }^{407}$

There is, however, another esoteric dimension of Taqiyyah that Enayat does not address in his book. This relates to the self-perception of the Shī'ah community as the "bearers and protectors" of Wilāyah and Walāyah, which they viewed as the core teachings of Islam. Belief in such a unique position demanded Shī'ah Muslims to consider their very existence as a sacred object. Shī'ah self-perception also meant that their collective survival was of utmost -spiritual- importance for it was necessary for the protection of the "Divine Secrets." The doctrine of Taqīyyah, therefore, was not merely to protect secret teachings. It also meant to protect a "chosen community." 408 Several Hadīths reinforced this communal aspect of Taqīyyah. These Hadīths often ties the

\footnotetext{
${ }^{407}$ For more information on this extensive Shī $\overline{1} \mathbf{1}$ network, its sophisticated division of labors, and its many layers -such as Nuqabā, Nuzarāā, Du'āt, and Du'āt al-Du'āt-see Feirahi, Davoud. Tārīkh Tahawwwūl Duwlat dar Islām. pp. 241-3. Tha'ālibī argues that the clan of Banī 'Abbās successfully used parts of this extensive Shi' 'i network in their struggle against the Umayyad dynasty, which eventually led to the establishment of the Abbasid dynasty in 750 C.E. [see below for more discussion and also Tha'ālibīi, 'Abd al-'Azìz. (1995). Suqūt al-Dawlah al-Umawìyah wa Qīyām al-Dawlah al- 'Abbāsìyah. Beirut: Dār al-Maghrib al-Islāmī].

${ }^{408}$ The notion of Shī'ah community as a "chosen community" has one of its roots in Shī'ah Hadīths. In one reported tradition, the sixth Shī'ah Imām instructs one of his disciples, Ibn Abī Ya'für, to protect his beliefs by practicing Taqiyyah. In justifying his instruction, the Imām argues that "you [i.e. the Shī'ahs] among the people are like honeybees among the birds. Had the birds known what [precious secrets] honeybees carry within, they would have destroyed the bees altogether and at once" [see Muhammad al-Riyshahrī, Mīzann al-Hikmah, Vol. 4, p. 3652, Hadīth no. 4178]. See the following Chapter for more discussion.
} 
necessity of Taqīyyah with the "rights of the Shī'ah community." instance, relates the practice of Taqīyyah to the protection of the Shī'ah "brethren.,"410 Some of the most legally binding descriptions of Taqīyyah may be found in this body of Shī' $\overline{1}$ traditions. In these Hadīths, Shī'ah Muslims are encouraged to "know what Taqīyyah entails" in any given circumstances. ${ }^{411}$ The under-defining character of these Hadīths is yet another indication of the fluidity of the doctrine of Taqīyyah and its circumstantial and contingent nature.

The above Qur'ānic and Hadīth foundations are the reason behind many prominent Shī'ah jurists' unequivocal emphasis on the necessity of Taqiyyah. The writings of these jurists on the subject show the existence of a general consensus about the meaning of the term Taqīyyah. In Shī‘̄i legal texts, Taqīyyah often refers to acts of prudence and discretion in dealing with one's potential enemy in order to protect one's life and/or belongings or to protect one's community. Furthermore, the "enemy" is often understood as someone with a different religious belief system. In dealing with such an enemy, Taqīyyah is a legal permission to practice expediency including, but not limited to, concealing one's true beliefs. ${ }^{412}$

\footnotetext{
${ }^{409}$ In a Ḥadīth by the fourth Imām, for instance, "abolishing Taqìyyah" is mentioned along with "violating the rights of the brethren" as "unforgivable sins" in the eyes of God [see al-Hurr al- 'Āmilī, Wasā'il alShī ah fì Tahṣīl al-Masā’ il al-Sharī'ah, Vol. 11, p. 474].

${ }^{410}$ For this and quite a number of other similar Hadīths, see Ibid. Vol. 11, pp. 472-5.

${ }^{411}$ See, for instance, the Hadīth by the tenth Imām in Ibid. Vol. 11, p. 475.

${ }^{412}$ As mentioned before, the notion of Taqiyyah - especially for the purpose of protecting one's life against non-Muslims- exists in both Sh̄̄'1̄ and Sunnī legal discourses. See, for instance, Shaykh al-Mufĩd, Tașhīh al-I'tiqādāt al-Imāmīyah; Amīn al-Islām Ṭabarsī, Majma al-Bayān; Shaykh al-Anșāiñ, Kitāb al-Makāsib; Sayyid Ḥasan al-Bujnūrdī, al-Qawā id al-Fiqhīyah; Mahmūd al-Ālūsī, Rūh al-Ma 'ānī fi Tafsìr al-Qur'ān al-'Azīm wal-Sab' al-Mathānī; Muḥammad Rashīd Riḍā, Tafsīr al-Minār; Fakhr al-Dīn Rāzī, Tafsīr alKabìr; Ibn Kathīr, Tafsìr al-Qur' ān al- 'Azīmm; and Abū al-Qāsim Zamakhsharī, al-Kashshāf 'an Haqā 'iq al-
} 
One of the earliest Shī'ah theologians, Muhammad ibn Bābawayh al-Qumī, ${ }^{413}$ equates the religious necessity of observing Taqiyyah with that of Muslim daily prayers. ${ }^{414}$ In fact, he goes even further to argue that "Taqiyyah is religiously obligatory and its abolishment is not allowed until the appearance of the Imām al-Qā'im[ ${ }^{415}$ at the end of the time]." ${ }^{416}$ Later Shī'ah theologians and jurists continued to write about the necessity of practicing Taqiyyah -especially for those living under unjust rulers- in order to protect one's survival as well as that of the community. Mūhammad ibn Makkîn

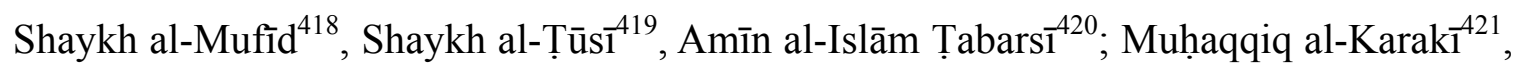

Tanzīl wa 'Uyūn al-Aqāwīl fi Wujūh al-Ta'wīl. It seems that the Sunnī legal discourse often considers Taqīyyah as a "permissible," or Mubāh, act in "extreme conditions" while Shī‘ì discourse differentiates among "obligatory," "permissible," and "forbidden" cases of Taqīyyah. See below for further discussion.

${ }^{413} \mathrm{He}$ is also known as Shaykh al-Ṣadūq (d. 991 C.E.).

${ }^{414}$ See Shaykh al-Ṣadūq, al-I'tiqādāt fì Dīn al-Imāmìyah. p. 107.

${ }^{415}$ Al-Qā'im is one of the epithets for the twelfth Shī'ah Imām, Muhammad al-Mahdī, who is believed to be hidden and is believed to reappear at the end of the time. See the following Chapter for some more discussion of Shī'ah eschatology.

${ }^{416}$ See Ibid. p. 108. This argument is based on a Hadīth reported from the eighth Shī'ah Imām in which Taqiyyah is declared obligatory till the return of the "hidden Imām," i.e. the end of the time. In the same Hadith, the Imām declares that "whoever abolishes the practice of Taqiyyah prior to that time [i.e. the coming back of the "hidden Imām"] is not of us" [see al-Hurr al- 'Āmilī, Wasă'il al-Shī'ah fì Tahṣìl alMasā'il al-Sharī'ah, Vol. 11, p. 466]. According to "Allāmih Majlisī, in another Hadīth, Ja'far ibn Muhammad states that as the time of the return of the "hidden Imām" approaches, the practice of Taqiyyah becomes more prevalent -or necessary [see "Allāmih Majlisī, Bihhār al-Anwār, Vol. 72, p. 434; and also in al-Hurr al-'Āmilī, Wasā'il al-Shī'ah fì Tahṣīl al-Masā’il al-Sharī'ah, Vol. 11, p. 462].

${ }^{417}$ d. 1384 C.E. He is also known as Shahīd al-Awwal, or the First Martyr. See Shahīd al-Awwal, alQawā'id wal-Fawā'id fill-Fiqh wal-Ușül wal- 'Arabìyah, Vol. 2, p. 155. Shahīd al-Awwal relates Taqīyyah to the practice of Mujāmilah, which means amiability and agreeableness. As will be discussed, Taqīyyah has also been associated with Mudārāt, which implies amicable coexistence [see Enayat, Hamid. Modern Islamic Political Thought. p. 177; and 'Allāmih Majlisī, Bihāar al-Anwāar, Vol. 72, p. 401]. The Mudārātī Taqīyyah is sometimes called Taḥbībī, which implies "displaying affection."

${ }^{418}$ See Shaykh al-Mufīd, Tașhịh al-I 'tiqādāt al-Imāmìyah, p. 137. Shaykh al-Mufìd notices that the Shī'ah Imāms ordered some of their followers to practice Taqiyyah while asked others to reveal their beliefs in order to invite people "to the Truth." In the latter case, however, there was no fear of being harmed due to abandoning Taqiyyah. Based on this observation, Shaykh al-Mufĩd concludes that practicing Taqiyyah is sometimes obligatory while in other situations it might not be allowed [see Ibid.]. 
and Shaykh al-Anșārîn ${ }^{-422}$, among others, have written about the legal aspects of the doctrine of Taqīyyah, its conditions, and its limits. ${ }^{423}$ Jurists such as Shaykh al-Ṭūsī and Aḥmad ibn Idrīs Hillî̀ $^{-424}$, in particular, categorically reject Taqīyyah when the issue of Dimā', or spilling of blood, might be an outcome. This legal qualification on the practice of Taqīyyah is based on a Hadīth reported from the fifth Shī'ah Imām. According to the Hadīth, "Taqīyyah has been allowed for the purpose of protecting bloods [from being spilled]; once [the practice of Taqiyyah] leads to the [spilling of] blood, Taqiyyah no

\footnotetext{
${ }^{419}$ See Shaykh al-Ṭūsī, al-Tibyān fì Tafsìr al-Qur 'än, Vol. 2, p. 435. Shaykh al-Ṭūsī reports a tradition from the Prophet regarding Taqìyah, which Sunnī jurists, according to him, have "misinterpreted." Sunnī jurists have understood this particular tradition as an indication that Taqiyyah is allowed; yet revealing one's true belief even when one might die for doing so is preferable. Shaykh al-Tūsì then rejects this interpretation and asserts that observing Taqiyyah in such conditions is "obligatory," or al-Wājib.
}

${ }^{420}$ See Amīn al-Islām Țabarsī, Majma 'al-Bayān, Vol. 2, p. 272. This is Amīn al-Islām TTabarsī’s commentary on the verse 40:28 of the Qur'ān that, as mentioned before, is one of the three Qur'ānic verses used to justify Taqīyyah.

421 See Muhaqqqiq al-Karakī, Rasā'il al-Karakī, Vol. 2, pp. 49-54. Muhaqqiq al-Karakī argues that justification of Taqīyyah comes from not only the consensus of Shī'ah jurists but also "the deeds and the sayings" of the Shī'ah Imāms [see Ibid. p. 51]. For more discussion of the "deeds" of the Shī'ah Imāms regarding Taqìyah, see below.

${ }^{422}$ See Shaykh al-Anșārī, al-Taqīyyah. This short treatise belongs to a genre of writings by various Shī'ah scholars including, for instance, Muhaqqiq al-Karakī on the notion of Taqīyyah. These short treatise were in part an effort to respond to some of the accusations raised against Shī'ah Muslims for their practice of Taqīyyah. The opponents of Taqìyyah maintained that by observing Taqīyyah, Shī'ah Muslims were in fact being hypocrite. In his essentially Realist argument, Shaykh al-Anșārī tries to sketch the legal boundaries of Taqiyyah and the type of "dire conditions," or Ahwāl al-Iḍtirār, that would render practicing Taqīyyah permissible, preferable, or even obligatory. He also reviews the conditions in which practicing Taqiyyah is not preferable, such as pretending to be a disbeliever, as well as conditions in which practicing Taqīyyah is forbidden, such as drinking alcoholic beverages or an act of Taqiyyah that could lead to the death of another Muslim [see Ibid. pp. 39-40 and Ibid. p. 57]. Shaykh al-Anșārī clearly expands the notion of Taqiyyah from its usual connotation to its essence of observing prudence [see Ibid. pp. 53-5]. See below for further discussion of the broader implications of the doctrine of Taqìyah and its consequences for Shī'i strategic cultures.

${ }^{423}$ Another useful juridical discussion of Taqiyyah can be found in the work of one of the prominent Shī'ah jurists of the past century, Sayyid al-Bujnūrdī (d. 1975). See Sayyid Hasan al-Bujnūrdī, al-Qawā 'id alFiqhīyah, Vol. 5, pp. 47-81.

${ }^{424}$ See Enayat, Hamid. Modern Islamic Political Thought. p. 179; Shaykh al-Anșārī, al-Taqūyyah, p. 57;

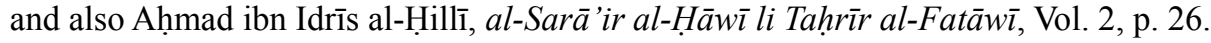


longer applies." 425 In another Hadīth by the sixth Imām, Taqīyyah is said to be impermissible if it leads to "the corruption of the religion." ${ }^{, 426}$ Amīn al-Islām Tabarsī, on the other hand, reports a tradition from the first Shī'ah Imām, 'Alī ibn Abī Ṭālib, in which Taqīyyah is related to Wilāyah and Walāyah. In this Hadīth, protection of one's self is legally permitted as long as one continues to be a Mawāl, or a follower of the [Imām's] Walāyah, in one's heart. ${ }^{427}$ As Enayat writes, however, a common theme in nearly all of these legal writings is that Taqiyyah is "an exceptional dispensation granted only in cases of emergency and compulsion (idțirār). ${ }^{, 428}$ At the same time, the legal discussion of the subject has created a small yet complicated body of juridical arguments with various categorizations of obligatory ${ }^{429}$, preferable $^{430}$, permissible ${ }^{431}$, non-preferable ${ }^{432}$, and

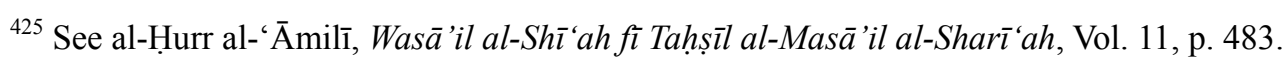

${ }^{426}$ See Shaykh al-Anșāīi, Kitāb al-Ṭahārah, Vol. 2, p. 400; and Abū al-Qāsim al-Khū'ī, Kitāa al-Ṭahārah, Vol. 4, pp. 253-68.

${ }^{427}$ See Amīn al-Islām Țabarsī, Kitāb al-Iḥtijāj, Vol. 1, pp. 354-5; and al-Ḥurr al-‘Āmilī, Wasā'il al-Shī'ah fì Tahṣill al-Masā'il al-Sharī'ah, Vol. 11, pp. 478-9.

${ }^{428}$ Enayat, Hamid. Modern Islamic Political Thought. p. 177 (emphasis in the text). The notion of Dār alTaqīyyah, or the Abode of Taqīyyah, has been used in Shī'ah Hadīths in reference to this situation of Iḍtịār, which leads to the obligation to observe Taqīyyah [see al-Hurr al-'Āmilī, Wasā'il al-Shī'ah fì Tahsị̀l alMasā'il al-Sharī'ah, Vol. 11, p. 466]. See also Ibid. Vol. 11, p. 468, Hadīths no. 1 and 2; as well as Ibid. Vol. 11, p. 469, Hadīth no. 8. According to Shī'ah Fiqh, Taqiyyah is not allowed in the absence of Iḍtirār [see Shaykh al-Anșārī, al-Taqīyyah]. As for the notion of Dār al-Taqīyyah itself, some Shī‘ī sources go as far to label the age of Occultation of the twelfth Imām as an example of Dār al-Taqìyyah. One of the Hadīth foundations of this argument is a discourse attributed to the eighth Shī'ah Imām in which he qualifies the permissibility of Jihād with "infidels" in the absence of the "just Imām." Such an absence is then identified as a characteristic of Dār al-Taqīyyah [see Muhammad Ḥasan al-Najafī, Jawāhir al-Kalām fì Sharh Sharāyi 'al-Islām, Vol. 21, pp. 12-3].

${ }^{429}$ As mentioned before, a key condition for the obligation of Taqiyyah is Iḍtirār.

${ }^{430}$ For instance, when the practice of Taqīyyah might lead to winning over one's enemies or helps strengthening the unity among Shī'ah and Sunnī Muslims. See below.

${ }^{431}$ For instance, when avoiding Taqīyyah might lead to one's "martyrdom" without endangering others in the community [see al-Hurr al-'Āmilī', Wasā'il al-Shī'ah fì Tahṣīl al-Masā'il al-Sharī'ah, Vol. 11, pp. 4767]. In such cases, both practicing and abandoning Taqīyyah may be legally permitted. 
forbidden ${ }^{433}$ acts of Taqīyyah. ${ }^{434}$ Enayat writes

"[f]our categories are particularly mentioned: (1) the enforced (ikrāhiyyah), (2) precautionary or apprehensive (khawfiyyah), (3) arcane (kitmāniyyah), and (4) symbiotic (mudārātī). The enforced taqiyyah consists of acting in accordance with the instructions of an oppressor, and under necessity, in order to save one's life. [...] The precautionary or apprehensive taqiyyah consists of the performance of acts and rituals according to the fatwās (authoritative opinions) of the Sunnī religious leaders, and in Sunnī countries. [...] The arcane taqiyyah is to conceal one's faith or ideology $[\ldots]$ to carry out clandestine activity for furthering religious goals. [...] Finally, the symbiotic type is simply a code of coexistence with the Sunnī majority, and of participation in their social and ritual congregations

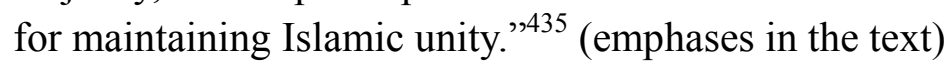

Despite these legal categorizations and differentiations of various types of Taqīyyah, the essential undertone of the doctrine of Taqìyyah has been one of prudence and expediency. Taqīyyah socialized Shī‘ ah Muslims to be sensitive to practical concerns and to appreciate what one may call "realism." ${ }^{436}$ As a result, the early Shī'ah community

${ }^{432}$ For instance, when the stakes are not high -e.g. protection of small properties [see Ibid. Vol. 11, pp. 4512], or when an act of Taqīyyah involves "pretending to reject the Shī'ah Imāms" [see Shahīd al-Awwal, alQawā'id wal-Fawā'id fill-Figh wal-Ușūl wal- 'Arabìah, Vol. 2, p. 158].

${ }^{433}$ For instance, when there is no Iḍtirīarr, or when Taqīyyah leads to violation of "another person's rights," or when it might cause "spilling of bloods," or when it may lead to religious "innovation" -i.e. Bid'ah [see al-Hurr al-'Āmilī, Wasā'il al-Shī'ah fì Tahșill al-Masā'il al-Sharī'ah, Vol. 11, p. 510]. According to the mainstream Shī'ì beliefs, Taqīyyah was forbidden to Husayn in Karbalā for the caliphate of Yazīd ibn $\mathrm{Mu}$ 'āwìyah was a blatant "corruption of the religion." For more discussion of Husayn's martyrdom in Karbalā and the alternative Shī‘i argument, which believes that Husayn could have practiced Taqìyyah, see the preceding Chapter.

${ }^{434}$ For a classical example of the legal discussion of these five categories of Taqīyyah, see Shahīd alAwwal, al-Qawā'id wal-Fawā'id fïl-Fiqh wal-Ușül wal- 'Arabìyah, Vol. 2.

${ }^{435}$ See Enayat, Hamid. Modern Islamic Political Thought. pp. 177-8. For more on these four categories of

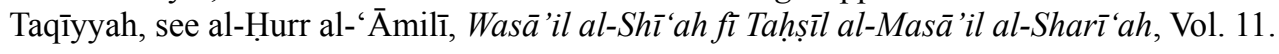

${ }^{436}$ For an insightful discussion of the forces of "idealism" and "realism" in Shī'ah political thought, see Enayat, Hamid. Modern Islamic Political Thought. pp. 26-8. 
internalized a sense of religious duty attached to efforts aimed at protecting the community, be it concealing their religious adherence or practicing Sunnī rituals. ${ }^{437}$ The implications of the doctrine, however, were far-reaching. In fact, the practice of Taqīyyah made it possible for the aforementioned extensive and underground Shì ${ }^{-} \overline{1}$ network to emerge. The creation of the network was a notable achievement especially when one considers the devastating blow the Shī'ah community had received in Karbalā. That Taqīyyah went beyond simply concealing Shī'̄i belief and that it implied strategies of expediency and prudence could be seen in the lives of the Shī'ah Imāms. In fact, the foundation of the doctrine of Taqiyyah may be found more easily in the actions of these Imāms, rather than their words.

The earliest precedence for the doctrine of Taqiyyah is recognizable in the life of the Shī'ah patriarch, 'Alī ibn Abī Țālib. Following the death of the Prophet in 632 C.E., 'Alī was marginalized by the powerful sectors within the tribe of Quraysh. ${ }^{438}$ For the next twenty five years, he reluctantly acquiesced to the caliphate of Abū Bakr, 'Umar ibn alKhațạāb, and 'Uthmān ibn 'Affān. During this long period, 'Alī's relationship with the sitting caliphs was a sophisticated one. On the one hand, 'Alī was adamant about his right to succeed the Prophet. ${ }^{439}$ On the other hand, however, he offered these caliphs his

\footnotetext{
${ }^{437}$ Using an analogy, the sixth Shī'ah Imām instructs his followers to internalize Taqīyyah so that it becomes their "overgarment and undergarment" at once. In other words, the Imām seems to demand expediency to become the second nature of the Shī'ah community [see al-Hurr al- 'Āmilì, Wasä'il al-Shī'ah fì Tahṣīl al-Masā’il al-Sharī'ah, Vol. 11, p. 466].

${ }^{438}$ See Madelung, Wilferd. The Succession to Muhammad. Quraysh was the tribe of the Prophet, and that of the first four caliphs. For a discussion of the political context of the selection of the first caliph, Abu Bakr, and especially of the tribal politics involved in the process, see Feirahi, Davoud. Tärīkh Tahawwūl Duwlat dar Islām. pp. 158-9.

${ }^{439}$ For his explicit statement regarding the issue of caliphate, see "Alī ibn Abī Ṭālib, Nahj al-Balāghah, Sermon 3 -also known as the "Sermon of Shiqshiqiyyah."
} 
assistance and his advice from time to time. ${ }^{440}$ 'Alī justified this complex relationship by expressing his concerns for the future of Islam and what harm his protest against the caliphs might do to the Muslim community. ${ }^{441}$ Nevertheless, the "twenty-five year silence" served as a "tradition foundation," or Sunnah, behind the doctrine of Taqīyyah in Shī'ah Islam. Even though 'Ali's accommodation of the three caliphs was associated to the issue of "future of Islam" instead of the concern for his own survival, it was understood as an example of observing Taqīyyah by the Shī`ah patriarch, hence establishing the broader implications of Taqīyyah.

In regards to the doctrine of Taqiyyah, however, it must be noted that 'Alī's contribution has been more restrictive than permissive. As will be discussed in the following section ${ }^{442}$, 'Alī's political legacy is often associated with his uncompromising adherence to his principles during his caliphate. Even during the twenty-five years of "political silence" prior to his caliphate, "Alī refrained from engagement in the tribal balance-of-power politics, further - politically- marginalizing himself. ${ }^{443}$ The resulting paradigm of "principled action" in Shī'ah Islam later on qualified the doctrine of Taqīyyah in noticeable ways.

The doctrine of Taqiyyah found its next reinforcements in the lives of the second and the third Imāms, namely Hasan and Husayn. Hasan's peace treaty with Mu'āwīyah

\footnotetext{
${ }^{440}$ For the examples of the helps the three first caliphs received from 'Alī see Shaykh al-Mufìd, al-Irshād, Vol. 1, pp. 201-212; and also Muḥammad ibn Jarīr al-Ṭabarī, Tārīkh al-Ṭabarī, Vol. 3; Ibn al-Athīr, alKāmil fìl-Tārīkh, Vol. 3; and Aḥmad ibn Abī Ya'qūb, Tārì̄kh Ya'qūbì, Vol. 2.

${ }^{441}$ See, for instance, 'Alī ibn Abī Ṭālib, Nahj al-Balāghah, Letter 62.

${ }^{442}$ See the section titled "Principled Action and Expediency: The Legacy of 'Alî̄" below.

${ }^{443}$ See Madelung, Wilferd. The Succession to Muhammad.
} 
ibn Abī Sufyān signed in 661 C.E. ${ }^{444}$ has become one of the most debated aspects of Shī'ah history among Shī'ah commentators. His concession of the caliphate to the archenemy of his father has called for complex intellectual and theological arguments by the Shī'ahs to defend the actions of their Imām. The main thrust of these arguments, however, has been the pragmatic concerns of Hasan regarding the prospect of a war with the organized army of Mu'āwīyah ibn Abī Sufyān. ${ }^{445}$ As a result, the peace treaty is sometimes associated with the practice of Taqīyyah. ${ }^{446}$ Hasan's brother, Husayn, also continued the same expedient approach upon becoming the third Shī'ah Imām in 670 C.E. Even though Husayn is generally associated with the more assertive doctrine of Shahādah and the events of Karbalā, he did observe Taqīyyah as long as Mu'āwīyah ibn Abī Sufyān was alive. ${ }^{447}$ This constituted ten years of Ḥusayn's imamate from 670 C.E. to 680 C.E. It was only in the months that followed the death of $M u^{\prime} \bar{a} w \bar{y} y a h$ ibn Abī Sufyān when Husayn refused to observe Taqīyyah. The result, as discussed in the preceding Chapter, was his death in the same year in Karbalā.

\footnotetext{
${ }^{444}$ See Muhammad ibn Jarīr al-Ṭabarī, Tārīkh al-Ṭabarī, Vol. 4, pp. 126-9; and Ibn al-Athīr, al-Kāmil fïlTārīkh, Vol. 3, pp. 404-7.

${ }^{445}$ See Shaykh al-Ṣadūq, 'Ilal al-Sharāyi', Vol. 1, pp. 210-9; 'Allāmih Majlisī, Bihār al-Anwār, Vol. 44, pp.1-33; and Amīn al-Islām Ṭabarsī, Kitāb al-Iḥtijāj, Vol. 2, pp. 8-12.

${ }^{446}$ Ayatollah Kāẓim Sharī'atmadārī (d. 1986), for instance, favored cautious "quietism" during and after the Islamic Revolution in Iran by referring to "Imām Hasan's tradition" and to the Shī'i principle of Taqīyyah [M. Mesbahi, Interview, February 27, 2012]. Ayatollah Sharı̄'atmadārı̄'s argument was in line with Hasan's own justification of the peace treaty with Mu'āwīyah ibn Abī Sufyān. In a conversation with some of his followers who protested against the peace treaty, Hasan argues that the treaty was necessary so that "you and I may survive among them [i.e. the enemies]" [see Muhammad al-Riyshahrī, Mīzāan al-Hikmah, Vol. 2, p. 1620].

${ }^{447}$ See, for instance, Muhammad ibn Jarīr al-Ṭabarī, Tārīkh al-Ṭabarī, Vol. 4, p. 126; Amīn al-Islām Țabarsī, Kitāb al-Ihtijājj, Vol. 2, pp. 20-1; and Abū Muḥammad ibn Qatibah al-Daynūrī, al-Imāmah walSìyāsah, Vol. 1, p. 201.
} 
It was, however, after the horrifying events of Karbalā that Taqīyyah became the essential modus vivendi of the Shī'ah community and that of the Shī'ah Imāms. The Imāms who succeeded Husayn -with arguably the exception of Mūsā ibn Ja'far, the seventh Imām- are believed to have chosen the "politics of Taqiyyah."448 The fact that these Imāms observed Taqīyyah, however, does not mean that they concealed their Shī' $\overline{1}$ beliefs; for these were prominent figures known to be the heads of the Shī'ah community. Instead, their observance of Taqīyyah meant a particularly prudent approach in politics. The fourth Shī'ah Imām, 'Alī ibn Husayn ${ }^{449}$, was one of the few male companions of Husayn who survived the Battle of Karbalā. Yet, he never sought to avenge his father's death by the Umayyad. Other branches of Banī Hāshim ${ }^{450}$ did rebel against the Umayyad

${ }^{448}$ Feirahi, Davoud. Tārīkh Tahawwūl Duwlat dar Islām. p. 252.

${ }^{449} 658$ - 712 C.E. He is also known by his epithets al-Sajjād and Zayn al-‘'̄abidīn.

${ }^{450}$ Along with Banī Umayyah, i.e. Sons of Umayyah, Ban̄̄ Hāshim, i.e. Sons of Hāshim, was one of the main clans of Quraysh, the tribe of the Prophet. Prior to Islam, Banī Umayyah was the most powerful clan of Quraysh. When Muhammad, who belonged to Banī Hāshim, revealed his prophetic mission, the fiercest opposition came from Banī Umayyah. With the success of the Prophet in establishing his authority, therefore, Banī Umayyah was temporary marginalized. This relative marginalization continued during the reign of Abū Bakr, who was from Banī Tamīm clan of Quraysh, and 'Umar ibn al-Khațtāb, who was from Banī 'Adī clan of that tribe. With the rise of 'Uthmān ibn 'Affān, who was from Banī Umayyah, to the caliphate in 644 C.E., Banī Umayyah began to resume their position of power. Their return was so successful that by the time 'Alī, who was from Banī Hāshim, became the caliph in 656 C.E., it was already impossible to reverse Banī Umayyah's hold on power. 'Alī’s archenemy, Mu'āwīyah ibn Abī Sufyān was in fact the head of Banī Umayyah at the time and the rise of the Umayyad dynasty had already been in the making. After 'Alī, Ban̄i Hāshim was divided into several sub-clans. The most important among these were the 'Alawīs, i.e. Sons of 'Alī, and Banī 'Abbās, i.e. Sons of 'Abbās, the Prophet's uncle. The Shī'ah Imāms all belong to the 'Alawī sub-clan of Banī Hāshim. Ban̄i 'Abbās were either identified themselves as Shī'ah or were sympathetic to the $\operatorname{Sh}^{\top}{ }^{\top} \overline{1}$ cause. This is probably why they were a part of the underground $\operatorname{Sh}^{\top}{ }^{\prime} \overline{1}$ network that emerged after Karbalā. It was partly due to employing this network that Banī 'Abbās managed to advance their fight against the Umayyad dynasty. Later on, however, Banī 'Abbās and the 'Alawīs parted ways. This divergence culminated in 750 C.E. when the former group rose to power by establishing the Abbasid caliphate - under the banner of returning the caliphate to the "family of the Prophet." The Abbasid caliphs persecuted the "Alawīs and their Imāms as potential challengers to their claim of political legitimacy [see Ibid. pp. 241-51; and Ahmad ibn Abī Ya'qūb, Tārīkh Ya'qūbī, Vol. 2]. The fear of the 'Alawīs also caused the Abbasid dynasty to adopt Sunnī jurisdiction and Sunnī theology as the legal and religious foundations of the state. Due to this choice, Feirahi argues that after the establishment of the Abbasid caliphate, the term Shī'ah began to be used exclusively in reference to the 'Alawīs, and no longer included Banī 'Abbās [see Feirahi, Davoud. Tārīkh Tahawwwūl Duwlat dar Islām. p. 265; and Ibid. p. 182. 
to revenge the martyrdom of Husayn. In fact, one of the most important Shī's uprisings against the Umayyad dynasty took place during 'Alī ibn Husayn's imamate. The leader of the rebellion was Mukhtār al-Thaqafi ${ }^{451}$ whose avowed mission was to avenge Husayn. Yet, he did not claim this revenge on behalf of 'Alī ibn Husayn. Instead, he fought under the banner of Muḥammad ibn Hanafĩyyah (d. 700/701 C.E.), who was Husayn's stepbrother. Many Shī‘ahs joined Mukhtār al-Thaqafì in this uprising that seriously challenged the hold of Banī Umayyah to power. Yet 'Alī ibn Husayn refrained from public engagement in the affair and, according to the Shī's sources, referred the matter to his uncle, Muhammad ibn Hanafiyyah. ${ }^{452}$ Meanwhile, according to the mainstream Shī'ah historiography, 'Alī ibn Husayn initiated a quiet "educational movement” aimed at

Also, Ibid. p. 160-1 offers a useful discussion of the rising political tensions between Banī Hāshim and Banī Umayyah following the death of the Prophet]. For a classical account of the tensions between Banī Hāshim and Banī Umayyah, see Taqī al-Dīn Abī Muhammad al-Maqrīzì, al-Nizā' wal-Takhāṣum fìmā bayn Ban̄̄ Umayyah wa Ban̄̄ Hāshim.

${ }^{451}$ Mukhtār al-Thaqafi's rebellion was eventually crushed by the forces of Umayyad caliph and he was killed in 687 C.E. See Muhammad ibn Jarīr al-Ṭabarī, Tārīkh al-Ṭabarī, Vol. 4, pp. 513-76; and Ibn alAthīr, al-Kāmil fìl-Tārīkh, Vol. 4, pp. 211-77.

${ }^{452}$ According to Shī'ah sources, 'Alī ibn Ḥusayn did give his implicit consent to Mukhtār al-Thaqafì’s uprising and Mukhtār al-Thaqafī also respected 'Alī ibn Husayn's high stature among the Shī'ah community [see 'Allāmih Majlisī, Bihār al-Anwār , Vol. 45, p. 339; Ibid. Vol. 45, p. 351; and, particularly for 'Alī ibn Husayn's implicit support, see Ibid. Vol. 45, p. 365. See also Aḥmad ibn Abī Ya‘qūb, Tārīkh $Y a ' q \bar{u} b \bar{i}$, Vol. 2]. Despite this mutually respectful relationship, however, there seems to be a general consensus among the historians that Mukhtār al-Thaqafĩ considered -or at least represented- Muhammad ibn Hanafiyyah as the head of the community and maybe even as the "Shī'ah Imām." Prominent contemporary historian, Sayyid Ja 'far Shahīdī, for instance, believes that 'Alī ibn Husayn did not respond to Mukhtār al-Thaqafís initial invitation sent to him; and after the uprising, he only partially approved of Mukhtār al-Thaqafì's acts of revenge [see Shahīdī, Sayyid Ja'far. (1995). Zindigānn̄ 'Alī ibn al-Husayn. Tehran: Daftar Nashr Farhang Islāmī. p. 92; and also Abū al-Ḥasan Mas'ūdī, Murawwij al-Dhahab wa Ma ādin al-Jawhar, Vol. 2]. As a result, later Shī'ah Imāms, while often speaking highly of Mukhtār alThaqafī, refrained from fully sanctioning his actions [see, for instance, 'Allāmih Majlisī, Bihāar al-Anwāar, Vol. 45, pp. 343-5]. 


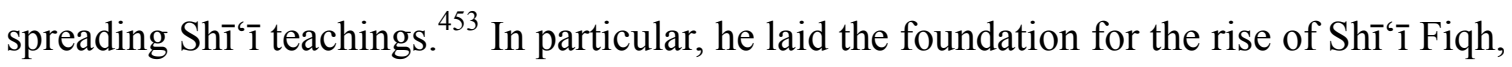
or jurisprudence, during the imamate of the next two Shī'ah Imāms. ${ }^{454}$

The fifth and the sixth Shī'ah Imāms, Muhammad ibn 'Alī and Ja'far ibn Muhammad, followed the same "politics of Taqīyyah." They permitted a selected number of their followers to serve in various governmental positions without revealing their Shì' $\overline{1}$ beliefs. ${ }^{455}$ These elite "secret Shī'ahs" proved to be helpful in protecting the Shī'ah community because of their high positions within the bureaucracy of the caliphate. The

\begin{abstract}
${ }^{453}$ One the important yet understudied Shī'i classical texts is Sahîfah al-Sajjädīyah, a book of prayers taught by 'Alī ibn Husayn. Along with the Qur'ān and Nahj al-Balāghah by 'Alī, Șahîfah al-Sajjādīyah is among the central texts in Shī'ah Islam. Sometimes dubbed as the "Sister of the Qur'ān," Șahîfah alSajjädiyah is more than a book of prayers however; for it lays the general ground of the Shì'i worldview through these prayers. The fifty four prayers of the mainstream version of the book cover a long list of subjects including questions of theology, divinity, prophethood, fate, and Providence; existential issues such as pain, suffering, death, sickness, health, desires, sorrow, fear, repentance, supplication, contentment, gratefulness, and humility; social issues such as parents, progeny, friends, neighbours, as well as discretion, poverty, and benevolence; rituals of Islam such as the "prayer of the night," pilgrimage, and fasting; the central Shī'i issues of justice and injustice; and finally a major discourse on ethics and high morals. As the diverse subjects of these prayers indicate, Șahīfah al-Sajjādìyah functioned as a set of reflections for the Shī'ah community following the disaster of Karbalā. This is why many Shī'ah authors have argued that it was 'Ali ibn Husayn who laid the foundations of what was to become the elaborate legal and theological edifice of Shī'ah Islam. Needless to say, he succeeded in spreading his teachings by resorting to an extremely prudent approach in politics justified by the flexible doctrine of Taqiyyah.
\end{abstract}

454 “Alī ibn Husayn's complex "politics of Taqīyyah" can also be recognized in the anti-Umayyad rebellion of the people of Medina. The revolt, also known as Qìyām al-Hurrah, took place about a year after the events of Karbalā and 'Alī ibn Husayn, who was a prominent figure in the city, did not support it. When the rebels took the control of the city in their hand, the family of Marwān ibn Hakam sought the protection of 'Alī ibn Husayn, which they were granted. Protection of Marwān ibn Hakam's family is significant for he was an archenemy of the 'Alawīs and, later on, he went on to become the fourth Umayyad caliph. The revolt was eventually crushed by the army of Yazīd ibn Mu'āwīyah and he ordered that prominent figures of Medina to be publicly humiliated. The only exception was 'Alī ibn Husayn who was treated with respect after the fall of the city. The Shi' 'ah sources argue that it was the Taqiyyah of the Imām during the revolt that spared him the public humiliation [see Muhammad ibn Jarīr al-Ṭabarī, Tärīkh al-Tabarī, Vol. 4, pp. 370-380; Ibn Kathīr, al-Bidāyah wal-Nihāyah, Vol. 6, pp. 261-3; Aḥmad ibn Abī Ya'qūb, Tārīkh Ya 'qūbì. Vol. 2, p. 250; and Shahīdī, Sayyid Ja'far. Zindigānī 'Alī ibn al-Ḧusayn]. The other aspect of 'Alī ibn Husayn's "politics of Taqīyyah" may be found in his adamant opposition to Shī'ahs' interactions with those associated with the Umayyad court. In a famous letter "Alī ibn Husayn strongly censures his former student, Muhammad ibn Muslim al-Zuhrī, for "cozying up to the unjust [Umayyad] rulers" and "accompanying the betrayers" [see Ibn Shu'bah al-Ḥarrānī, Tuhaf al- 'Uqül, p. 274-7].

${ }^{455}$ For an example of such permissions, see al-Ḥurr al- 'Āmilī̄, Wasā'il al-Shī'ah fì Tahsịll al-Masā'il alSharī'ah, Vol. 11, p. 460. 
"educational" consequences of the two Imāms' Taqīyyah, however, were more significant than implantation of their agents in positions of high power. By observing Taqiyyah, they managed to solidify the basic tenets of the Shī's School of jurisprudence during an extremely turbulent period of Muslim history. These two Imāms spent the majority of their lives quietly teaching large crowds of devoted followers. According to Shī'ī reports, these teachings covered a wide spectrum of subjects in theology, exegesis of the Qur'ān, logic, ethics, and jurisprudence. Both Muḥammad ibn ' $\mathrm{Al}^{-456}$ and Ja'far ibn Muhammad based their "system of education" in the city of Medina, a city that, while religiously and symbolically significant to Muslims, had become marginalized by the rise of such powerful centers of politics as Baghdad and Damascus. The retreat to Medina gave them a leeway to expand their circle of students. ${ }^{457}$ As the Ummayad dynasty was falling to its knees due to the internal conflicts as well as the forceful opposition of Banī 'Abbās, the Shī‘ah Imāms made sure to steer clear of politics. In Shī‘ah historiography, the "quietist" attitude of Muhammad ibn 'Alī and Ja'far ibn Muhammad is often viewed as arguably the most significant examples of practicing Taqiyyah. At the same time, the approach proved successful as, by the time of Ja'far ibn Muhammad's death in 765 C.E., Shī‘ah

\footnotetext{
${ }^{456}$ Muhammad ibn 'Alī was particularly influential in establishing the Shī'ī methodology of critical reasoning in jurisprudence. The method was then employed in practicing Ijtihād, i.e. the "process of arriving at judgements on points of religious law using reason and the [science] of principles of jurisprudence" [see Subḥān̄, Ja 'far. Doctrines of Shi 'i Islam., p. 182]. In regard to his epithet, al-Bāqir, and its relation to his method of critical reasoning, see Aḥmad ibn Abī Ya'qūb, Tārīkh Ya 'qūbì. Vol. 2; and Shaykh al-Ṣadūq, 'Ilal al-Sharāyi', Vol. 1, p. 233.

${ }^{457}$ Even in their teachings, Muhammad ibn 'Alī and Ja'far ibn Muhammad observed a form of Taqīyyah that is sometimes called Taqiīyyah fil-Hukm, i.e. "Taqiyyah in Opinion." This Taqiyyah refers to concealing one's jurisprudential opinion in order to protect oneself. Both Muhammad ibn 'Alī and Ja'far ibn Muhammad attracted large number of students among whom existed many non-Sh'`'ahs. The occasional discrepancies in the jurisprudential opinions of these Imāms are often related to their "Taqiyyah in Opinion" in responding to different audiences. See in particular Șafarī, Ni‘matullāh. (2003). Naqsh Taqīyyah dar Istinbāṭ. Qum: Būstān Kitāb Qum.
} 
Islam had already obtained an elaborate and comprehensive theological and juridical paradigm. $^{458}$

The broad implications of the doctrine of Taqiyyah go beyond the common understanding of "expedient concealment." That becomes more evident when one considers the political context of Ja'far ibn Muhammad's life. In 740 C.E., an important Shī'`i uprising broke out under the leadership of Zayd ibn 'Alī, son of the fourth Shī'ah Imām, 'Alī ibn Husayn. The revolt was against the crumbling Umayyad dynasty in order to reclaim the 'Alawī's right to the caliphate. ${ }^{459} \mathrm{Ja}^{\text {'far }}$ ibn Muhammad, however, did not join the revolt. While most of the Shī'ah community followed Ja'far ibn Muhammad's "quietism," some joined Zayd ibn 'Alī's movement and even considered him instead of Ja'far ibn Muhammad to be the Shī'ah Imām. Eventually, the revolt was suppressed by the Umayyad forces and Zayd ibn 'Alī was killed in the same year. Yet, the disagreement between the two sides of the Shī'ah community survived. The majority followed what was to become the Twelver Shī'ah Islam while the minority Zaydīyyah branched out.

\footnotetext{
${ }^{458}$ As mentioned before, most of the Shī`ah Hadīths are reported from the sixth Shī'ah Imām, Ja ‘far ibn Muhammad. In fact, given the central role played by Ja 'far ibn Muhammad in the development of the Shī' School of jurisprudence, this School is often called the "Ja "farī School of Fiqh" [see, for instance, Shaykh al-Mufĩd, al-Irshäd, Vol. 2, pp. 179-214 for a mainstream Shī'ī account of Ja'far ibn Muhammad's status in Shī'ah jurisprudence]. It must be added that both Muhammad ibn 'Alī and Ja'far ibn Muhammad are among the respected religious and scholarly authorities in Sunnī Islam as well.

${ }^{459}$ See Muhammad ibn Jarīr al-Ṭabarī, Tārīkh al-Ṭabarī, Vol. 5, pp. 481-506; and Ibn al-Athīr, al-Kāmil fìlTärīkh, Vol. 5, pp. 242-7.
} 
On the theological level, the alleged disagreement ${ }^{460}$ between Zayd ibn 'Alī and Ja'far ibn Muhammad was the result of their different understandings of the doctrine of Shahādah and that of Taqīyyah. Zayd ibn 'Alī understood his grandfather's martyrdom in Karbalā as setting a universal example to be -literally- followed. He saw the doctrine of Shahādah as a universal creed -a creed that only under extremely rare circumstances might give way to the doctrine of Taqīyyah. ${ }^{461}$ As a result, Zayd ibn 'Alī and his followers believed that whenever the opportunity to rise against "injustice" presented itself, it would be obligatory to engage in Jihād. ${ }^{462}$ Because of this interpretation, Zaydī Shī'ahs believed that the Imām must have two characteristics. First, he must be a "pious and knowledgeable" descendant of the Prophet through his daughter Fāttimah bint Muhammad. Second, he must rise against injustice by resorting to Jihād, i.e. Qiyām bil-

\footnotetext{
${ }^{460}$ Similar to the case of Mukhtār al-Thaqafî, the fact that the Shī'ah Imām did not publicly approve of Zayd ibn 'Alī's revolt did not prevent Shī'ah theologians to generally revere Zayd ibn 'Alī as a pious and knowledgeable member of Banī Hāshim. According to the mainstream reports, Ja'far ibn Muhammad paid deference to his uncle Zayd ibn 'Alī , and so did the following Shī'ah Imāms [see, for instance, Muhammad 'Alī al-Ardabīlī, Jāmi' al-Ruwāt, Vol. 1, p. 343; Shaykh al-Mufìd, al-Irshād, Vol. 2, pp. 172-3; and also Shaykh al-Șadūq, 'Uyūn Akhbār al-Ridhā, Vol. 2]. Some of the Shī'ah theologians, such as Shahīd alAwwal, have even argued that Zayd ibn 'Alī had had the implicit permission of the Imām in his revolt [see Shahīd al-Awwal, al-Qawā'id wal-Fawā'id fil-Fiqh wal-Ușül wal- 'Arabìyah, Vol. 2, p. 207]. Note that in contemporary -"revisionist"- Shī'ah historiography, one may find an attempt in softening the difference between Ja'far ibn Muhammad's approach and that of Zayd ibn "Alī. This "revisionist" historiography bourgeoned in particular after the Iranian Revolution of 1979. The "revolutionary Shī'ah intelligentsia" that emerged during the Revolution found it necessary to project the life of the Shī ah Imāms as unequivocally pro-revolution -and thus sanctioning every revolutionary move. The task proved to be a difficult one given the extensive tradition of political "quietism" and the practice of Taqiyyah by the Shī'ah Imāms. Nonetheless, an example of this "revisionist" historiography in regards to Zayd ibn "Alī's movement can be found in Razawi Ardekani, Abufazel. (1996). Shakhsìyat wa Qìyām Zayd ibn 'Alī. Tehran: Daftar Tablīghāt Islāmī.
}

${ }^{461}$ In fact, some have argued that Taqīyyah is forbidden in Zaydī Shī‘ah Islam [see Mullā Șaliḥ Māzandarānī, Sharh Ușūl al-Käfì, Vol. 9, pp. 118-136]. Later on, some branches of Zaydīyyah, such as Hādawīyyah, accommodated versions of Taqīyyah in part to explain Hasan ibn 'Alī's peace treaty with Mu'āwīyah ibn Abī Sufyān; for similar to Twelver Shī'ahs, Zaydī Shī'ahs consider Hasan ibn 'Alī as one of their Imāms.

${ }^{462}$ For a discussion of Shī'ī understanding of Jihād and its relation to the principle of Justice in Shī`ah Islam, see the preceding Chapter. 
Sayf, whenever it is possible. ${ }^{463}$ In contrast, Ja'far ibn Muhammad viewed the events of Karbalā as an extraordinary episode. He did not believe that Husayn's martyrdom must be universally followed by Shī'ah Muslims. Instead, he maintained that it was Husayn’s "protest against injustice" that was to be followed by Shī'ah Muslims -via various measures including the practice of Taqīyyah. Ja'far ibn Muhammad also had a broader understanding of the doctrine of Taqiyyah that entailed more caution compared to the assertive approach of Zayd ibn 'Alī. The notion of the universality of the doctrine of Shahādah, which is sometimes inaccurately associated with Twelver Shī'ah Islam, is therefore a Zaydī Shī'ah doctrine. Following this Zaydī doctrine, quite a number of “Zayd̄̄ Imāms" continued Zayd ibn 'Alī’s Jihād against the Umayyad and the Abbasid caliphs after his death. ${ }^{464}$

The split between Twelver Shī‘ahs and Zaydī Shī'ahs was an example of a recurring pattern in the early history of Shī'ah Islam. After the death of Husayn in Karbalā, the sub-clan of the 'Alawīs of Banī Hāshim divided into three branches. These included the Hasanīs, i.e. the descendants of Hasan, the Husaynīs, i.e. the descendants of Husayn, and the Kaysānīyyah, i.e. the descendants of Muhammad ibn Hanafĩyyah. ${ }^{465}$ All the Twelver Shī‘ah Imāms who succeeded Husayn came from the Husaynī branch of the 'Alawīs. Yet, none of them resorted to Jihād in revenge of their ancestor's martyrdom or

\footnotetext{
${ }^{463}$ See Shaykh al-Mufĩd, Awā'il al-Maqālāt fĭl-Madhāhib wal-Mukhtārāt, p. 39; Shaykh al-Mufīd, alMuqni 'ah, p. 655; Hasan ibn Mūsā Nawbakhtī and Sa'd ibn 'Abdullāh al-Qummi, Firaq al-Shī'ah, pp. 314; and Abū al-Hasan Mas'ūdī, Murawwij al-Dhahab wa Ma 'ādin al-Jawhar.

464 See Aḥmad ibn A'tham al-Kūfī, Kitāb al-Futūḥ, Vol. 8; Muhammad ibn Jarīr al-Ṭabarī, Tārīkh alTabarī, Vol. 5, 6 \& 7; and Ibn al-Athīr, al-Kāmil fïl-Tārīkh, Vol. 5 \& 6.

${ }^{465}$ See Feirahi, Davoud. Tārīkh Taḥawwūl Duwlat dar Islām. p. 252.
} 
to claim their right to the caliphate. Instead, other prominent figures from all the three branches ${ }^{466}$ of the 'Alawīs revolted against the Umayyad and the Abbasid from time to time. The reaction of the Shī'ah Imāms to most if not all of these recurring rebellions were neither open approval nor public condemnation, but almost everything in between. It ranged from silent consent to quiet dismissal and to implicit rejection. ${ }^{467}$ These sophisticated and calculated reactions were nothing short of the manifestations of their "politics of Taqiyyah."468 In an unusually direct explanation of his policy of nonengagement, Ja'far ibn Muḥammad argued that the uprising of other factions among Banī Hāshim had provided the Shī'ah community with the much-needed breathing space; for it had kept anti-Shī`ah forces occupied. ${ }^{469}$

The imamate of Ja'far ibn Muhammad also witnessed a significant transition from the Umayyad dynasty to the Abbasid dynasty in 750 C.E. As mentioned before, Ban̄i 'Abbās, who constituted the main oppositional thrust against the Umayyad dynasty,

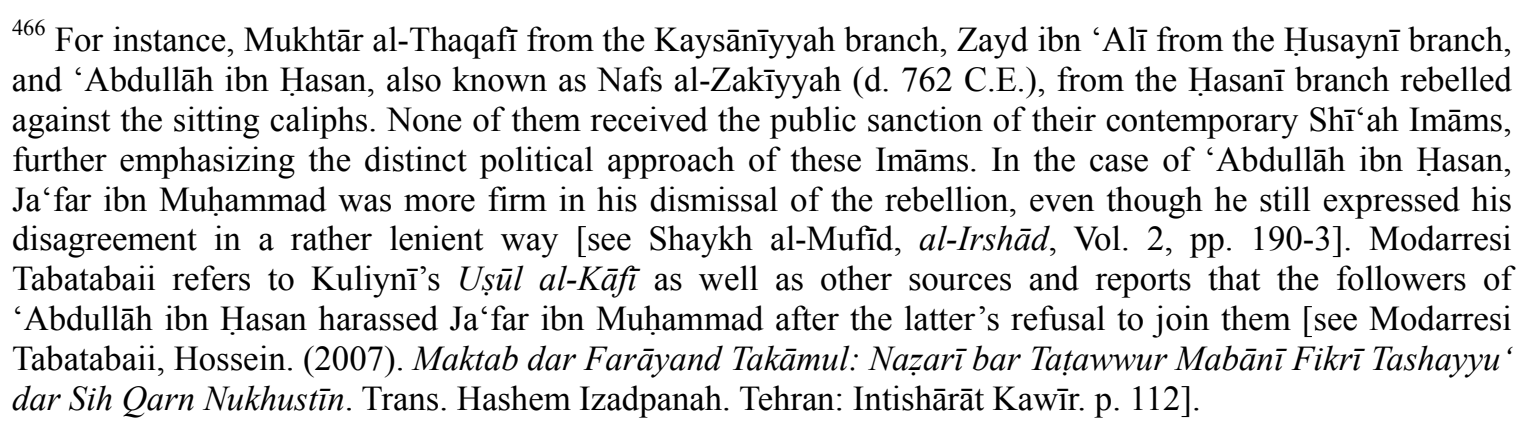

${ }^{467}$ In some of the more significant cases of these Shī'ah-sympathetic uprisings, the later Shī'ah Imām highly praised the efforts. In the case of Zayd ibn "Alī, for instance, his "martyrdom" was recognized by the Imāms who came after his death even though his contemporary Imām had not joined his campaign [see, for instance, 'Allāmih Majlisī, Biḥ̂̄r al-Anwār, Vol. 45, pp. 186-209]. This pattern of recognition after the event was arguably another example of practicing Taqīyyah for it increased the survivability of the Shi' $a$ ah community.

${ }^{468}$ See Feirahi, Davoud. Tārīkh Tahawwūl Duwlat dar Islām. p. 252.

${ }^{469}$ See Muhammad al-Riyshahrī, Mīzān al-Hikmah, Vol. 1, p. 182, Hadīith no. 238; and al-Hurr al-'Āmilī, Wasā'il al-Shì'ah fì Tahṣ̂̀l al-Masā'il al-Sharī'ah, Vol. 11, p. 39, Hadìth no. 12. 
employed the clandestine Shī's̄ network in their campaign. Moreover, their key strategy was to question the political legitimacy of the Umayyad dynasty and to call for the return of the caliphate to its legitimate bearers, namely "the family of the Prophet." The fact that Ja'far ibn Muhammad was a direct descendant of the Prophet rendered him an obvious candidate to whom Banī 'Abbās was referring. Yet, there seems to be a consensus among the Shī'ah historians that Ban̄̄ 'Abbās did not have the intention of offering the caliphate to the 'Alawīs once they succeeded. At any rate, Banī 'Abbās seemed to have managed to conceal their intentions of marginalizing the "Alawīs throughout their campaign in order to exploit the popularity of Ja'far ibn Muhammad among the Shī'ahs. ${ }^{470}$ The strategy created high expectations among the Shī'ah community regarding the political future of their Imām. In fact, upon the imminent success of Ban̄̄ 'Abbās movement, some marginalized elements within that movement approached Ja'far ibn Muhammad with an invitation to become the new caliph. ${ }^{471} \mathrm{He}$ refused the invitation possibly due to his awareness of the firm intention of Banī 'Abbās to establish an 'Abbāsī rather than an 'Alawī caliphate. ${ }^{472}$ Meanwhile, Ja'far ibn Muhammad's refusal to engage in politics when the environment appeared to be so favorable confused the Shī'ah community. Modarresi Tabatabaii believes that the Imām's "political silence," which was in fact the continuation of his father's and his grandfather's policy, was added to a series of

\footnotetext{
${ }^{470}$ See Feirahi, Davoud. Tārīkh Tahawwūl Duwlat dar Islām. p. 251.

${ }^{471}$ For more information on these pro-'Alawī individuals among Banī 'Abbās and their eventual failure, see Ibn Kathīr, al-Bidāyah wal-Nihāyah, Vol. 10, pp. 44-5.

${ }^{472}$ See Feirahi, Davoud. Tārīkh Tahawww̄̄l Duwlat dar Islām. p. 252; and Ahmad ibn Abī Ya'qūb, Tārīkh $Y a$ ' $q \bar{u} b \bar{l}$, Vol. 2. To counter the argument of the 'Alawīs, the Abbasid argued that their ancestor, 'Abbās, had been the legitimate successor to the Prophet. Unlike Shi' 'ahs, however, they did not refer to any particular Prophetic tradition in establishing this claim [see Feirahi, Davoud. Tārīkh Tahawwūl Duwlat dar Isläm. pp. 259-69].
} 
"disappointments" in the community. ${ }^{473}$ Despite their popularity and high stature among Ban̄̄ Hāshim and even among the larger Muslim society, Muḥammad ibn 'Alī and Ja'far ibn Muhammad had refused to engage in politics. ${ }^{474}$ Their decision led to a painful process of socialization of the notion of Taqiyyah among the Shī'ah Muslims. The experience further distanced the Shī'ah community from the Zaydīs. The less political and more esoteric image of the Imāms was also solidified in this period. ${ }^{475}$ This "spiritual image" of the Imāms had now had a solid theological foundation in the teachings of the fourth, the fifth, and the sixth Shī'ah Imāms.

The seventh Shī'ah Imām, Mūsā ibn Ja'far, was politically more active compared to his father and his grandfather. Yet, according to Shī'ah historiography, he was still an observer of the "politics of Taqiyyah." Despite his more vocal opposition to the Abbasid caliphate, for instance, he did not resort to violent measures. Instead, he successfully created an organized Shī'`̄ network by appointing representatives and deputies throughout

\footnotetext{
${ }^{473}$ See Modarresi Tabatabaii, Hossein. Maktab dar Farāyand Takāmul. pp. 34-6. Modarresi Tabatabaii reports that the more fervent followers of the Imām tried in vain to convince him to lead the anti-Umayyad movement while others simply expressed their disappointment. He writes "not only the Imām completely avoided political entanglements, but also he strongly proscribed his followers from doing so; and commanded that the Shi' ahs would not be allowed to join any of the active armed groups [among the opposition] or [even] to engage in Shī'i propaganda" [Ibid. p. 36]. The disappointment can be better understood when one considers that a large number of the Imām's followers resided in the strategic region of Iraq -the future seat of the Abbasid dynasty-, and that they were waiting for the Imām's permission to rebel against the Umayyad.

${ }^{474}$ With the benefit of the hindsight and given the ill fate of the Shī' $\overline{1}$ movements of the time, the disengagement of Muhammad ibn 'Alī and Ja'far ibn Muhammad from politics appear to be a wise course of action. To the contemporary Shī'ah society, however, the aloofness of the Imāms during "such ripe times" was baffling.

${ }^{475}$ Modarresi Tabatabaii believes that the Shī‘i doctrine of the "infallibility of the Imāms" -i.e. the doctrine of 'Ișmah- was also developed in the same period. Prior to this time, the Shī'ah community -except for a few number of devoted followers- revered their Imāms only as extremely pious and knowledgeable descendants of the Prophet [see Ibid. 32; Ibid. p. 39; and Ibid. pp. 73-87].
} 
the Muslim world. ${ }^{476}$ The network facilitated an increasing number of financial, legal, and educational interactions between the community and the Imām as well as within the community itself. The transactions that went through this network were under the radar of the Abbasid caliphate; and they posed a direct challenge to the authority of the caliph. As a result, the powerful Abbasid caliph Hārūn al-Rashīd ${ }^{477}$ eventually imprisoned Mūsā ibn

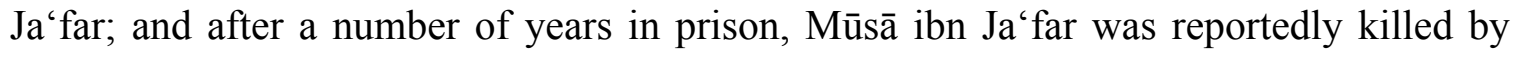
poison in 799 C.E. ${ }^{478}$

The next, somewhat controversial, application of the doctrine of Taqiyyah happened during the imamate of the eighth Imām, 'Alī ibn Mūsā ${ }^{479}$. Unlike the Umayyad system, which was essentially the reproduction of pre-Islam inter- and intra-tribal politics, the Abbasid political system was quite sophisticated. Ruling over a large multiethnic territory, the Abbasid had to balance different factions of the society over which they ruled. They soon adopted the complex bureaucracy of the earlier Persian Empires and hired a number of influential Persian viziers. To establish their political legitimacy, they also developed systematic relations with the prominent Sunn̄̄ 'Ulamā of the time. ${ }^{480}$ In this sophisticated political structure, the relationship between the Abbasid court and the 'Alawīs was even more complicated. The two had begun as implicit allies in their opposition to the Umayyad dynasty and had grown into enemies after the establishment

\footnotetext{
${ }^{476}$ See Ibid. pp. $40-1$.

477 d. 809 C.E.

${ }^{478}$ See Shaykh al-Mufĩd, al-Irshād, Vol. 2, pp. 237-243.

479765 - 817 C.E. He is also known by his epithet al-Riḍā.

${ }^{480}$ See Feirahi, Davoud. Tārīkh Tahawwū̄l Duwlat dar Islām. pp. 259-69.
} 
of the Abbasid dynasty, for the Abbasid saw the 'Alawīs as competitors with a more plausible claim to the caliphate. As mentioned before, this enmity had already been crystallized in the fate of the seventh Shī'ah Imām. Moving among their Arab, Persian, and Turkic bases, however, the Abbasid caliphs had to constantly revise the list of their enemies and their allies. The situation created a dynamic Abbassid-Shī'ah relationship. Traditionally, the Shī'ah Imāms had had a large number of followers in today's Iraq region. Gradually, however, they were obtaining a solid base among the Persians as well. This was in part due to the fact that the Persians had grown disillusioned with the Abbasid's initial campaign to reverse the Umayyad's "anti-Persian policies." The rising opposition between the 'Alawīs (or Shī'ahs) and the Abbasid, therefore, had led to proShī'ah leanings among the Persians. To appease the growing number of 'Alawī sympathizers in Persia, the Abbasid caliphs felt the necessity of employing radically different strategies vis-à-vis the Shī‘ah Imāms. As a result, while caliph Hārūn al-Rashīd had ordered the execution of Mūsā ibn Ja'far in prison, his son ${ }^{481}$ designated Mūsā ibn Ja'far's son as his successor. ${ }^{482}$

The Shī'ah historiography views 'Alī ibn Mūsā's response to the caliph's appointment as nothing short of practicing Taqīyyah. Prior to his appointment, 'Alī ibn Mūsā had been strictly following the usual "politics of Taqīyyah" for about fifteen years. During this period, he had engaged mainly in administering the affairs of the Shī'ah community through the large network of his delegates and devotees. He had also

\footnotetext{
${ }^{481}$ This is Ma'mūn al-'Abbāsī (d. 833 C.E.).

${ }^{482}$ According to Modarresi Tabatabaii, "many historians have speculated that the action of [the caliph] Ma'mūn [al-'Abbāsī in appointing 'Alī ibn Mūsā as his successor] was to contain the rising [Shī'î] fervor" [Modarresi Tabatabaii, Hossein. Maktab dar Farāyand Takämul. p. 42].
} 
exploited the breathing space caused by the death of Hārūn al-Rashīd and by the brutal rivalry between Hārūn al-Rashīd's two sons, Amīn al-‘Abbāsi ${ }^{483}$ and Ma'mūn al-‘Abbāsi, over the caliphate. ${ }^{484}$ Once Ma'mūn al-'Abbāsi consolidated his hold on power as the caliph, he made the Persian city of Marw in the eastern province of Khurāsān his interim capital city. The choice of Marw was already an indication of Ma'mūn al-'Abbāsī’s rising worries about the seething 'Alawī enclaves throughout Persia. In an attempt to contain the 'Alawīs, Ma'mūn al-'Abbāsī invited 'Alī ibn Mūsā from Medina to Marw" ${ }^{485}$ and designated him as the next caliph. According to the Shī'ah historiography, 'Alī ibn Mūsā was forced to accept the position, making him an unwilling figurehead. ${ }^{486}$

Before accepting Ma’mūn al-‘Abbāsī’s offer, however, 'Alī ibn Mūsā stipulated several conditions. These conditions manifest the prevailing attitude of Taqiyyah that had been taking roots in the political philosophy of the Shī'ah Imāms after Husayn.

${ }^{483}$ d. 813 C.E.

${ }^{484}$ See Feirahi, Davoud. Tārīkh Taḥawwūl Duwlat dar Islām. p. 277.

${ }^{485}$ According to Shī‘ah sources, 'Alī ibn Mūsā used the long trip from the Arabian Peninsula to Eastern Persia to "spread his Shī'i teachings." As a result, a large number of traditions going back to him is reported in Shī'ah theological texts. Many of these traditions are collected in 'Uyūn Akhbār al-Ridhā by Shaykh alȘadūq. This multi-volume book is among the main reference text in Shī'ah jurisprudence. It is in this collection where two of the explicit articulations of the Shī's notions of Wilāyah and Walāyah may be found. The first is called the "Hadīth Silsilah al-Dhahab," or the Hadìth of the Golden Chain. In this Hadīth, the Muslim doctrine of the Divine Unity is likened to a fort. The security of this fort, however, can be enjoyed only by those who submit to the Wilāyah and Walāyah of God, of the Prophet, and of the chain of the Shī'ah Imāms who followed the Prophet [see Shaykh al-Șadūq, 'Uyūn Akhbār al-Ridhā, Vol. 1, pp. 1435; and also 'Allāmih Majlisī, Bihāar al-Anwār, Vol. 49, pp.120-3].

The second widely quoted Hadīth specifically likens the "Wiāyah of "Alī ibn Abī Ṭālib" to a Divine fortress, protecting its residents "against the Divine Wrath" [see Shaykh al-Ṣadūq, 'Uyūn Akhbār al-Ridhā, Vol. 1, p. 146]. For more discussion of Wilāyah and Walāyah and their relation to the notion of metaphysical security, see the following Chapter.

${ }^{486}$ The Shī'ah historiography maintains that Ma'mūn al-'Abbāsī threatened 'Alī ibn Mūsā to death after the latter's initial refusal to accept the position. In order to protect himself, therefore, 'Alī ibn Mūsā conceded to Ma'mūn al-'Abbāsī’s proposal [see Shaykh al-Ṣadūq, 'Uyūn Akhbār al-Ridhā, Vol. 1, pp. 150-3]. 
According to Shī'ah sources, 'Al̄̄ ibn Mūsā's conditions included "not to be asked to interfere in the appointments of government's officials; not to be asked to interfere in government's procedures and protocols; not to be asked to serve as a judge; and not to be asked to engage in the politics of the Abbasid caliphate." 487 For someone who had been designated as the next caliph, these conditions appear to be counterintuitive. Yet, they suggest that 'Alī ibn Mūsā was not optimistic about the prospect of his political career within the Abbasid court. By these conditions, therefore, he tried to steer clear of the affair of that court. In the next few years prior to his death ${ }^{488}$, 'Alī ibn Mūsā's chief activity was to attend scholarly forums sponsored by Ma'mūn al-'Abbāsī. In these forums, which has become one of the hallmarks of Ma'mūn al-'Abbāsī’s caliphate ${ }^{489}$, 'Alī ibn Mūsā and his Muslim and non-Muslim interlocutors discussed various theological and ethical issues.

The next three Shī'ah Imāms, i.e. Muhammad ibn 'Alì̄ ${ }^{-490}$, Alī ibn Muhammad ${ }^{491}$, and Hasan ibn 'Alī ${ }^{-492}$, continued the "politics of Taqīyyah." They avoided political

\footnotetext{
${ }^{487}$ For 'Alī ibn Mūsā's conditions in response to Ma'mūn al-'Abbāsī’s "threats," see Shaykh al-Ṣadūq, 'Uyūn Akhbār al-Ridhā, Vol. 1, p. 152; Ibid. Vol. 1, p. 161; and Abū Ja'far Thiqat al-Islām Kuliynī, Ușūl alKäfi, Vol. 1, p. 489.

${ }^{488}$ According to Shī'ah sources, 'Alī ibn Mūsā was eventually poisoned by Ma'mūn al-'Abbāsī in 817 C.E. See Shaykh al-Șadūq, 'Uyūn Akhbār al-Ridhā, Vol. 1, pp. 267-8. Feirahi argues that after consolidating his authority over Persia, Ma'mūn al-'Abbāsī tried to appease, once again, his Arab base by killing his powerful Persian vizier Fạ̣l ibn Sahl, by poisoning 'Alī ibn Mūsā, and by his return to Baghdad -i.e. the traditional seat of the Abbasid dynasty [see Feirahi, Davoud. Tārīkh Tahawwūl Duwlat dar Islām. p. 277].

${ }^{489}$ See Cooperson, Michael. (2005). Al-Ma'mun. Oxford: Oneworld Publications.

${ }^{490} 810$ - 835 C.E. He is also known by his epithets al-Taq̄i and al-Jawād.

${ }^{491} 827$ - 868 C.E. He is also known by his epithets al-Hādī and al-Naqī.

${ }^{492} 846$ - 874 C.E. He is also known by his epithet al-'Askarī.
} 
engagements and quietly expanded the Shî'î network of representatives and deputies initially organized by Mūsā ibn Ja'far. They also reduced their engagement with the Shī'ah community by further delegating partial authorities to their deputies. ${ }^{493}$ The disengagement was, in part, due to the rising pressure lifted against the Imāms by the Abbasid caliphs. The result was socialization of the Shī ah community to be able to survive in the absence of the Imām. To achieve such an objective, the doctrine of Taqīyyah was of increasing importance. It taught Shì ${ }^{`}$ ah Muslims to be self-sufficient and to be extra cautious in dealing with their enemies. It also encouraged them to be prudent when relying on their allies.

Historically, the lives of the Shī'ah Imāms -with few, yet significant, exceptionshave been shaped by the practice of Taqiyyah. The different sociopolitical contexts in which these Imāms practiced Taqīyyah provided the Shī‘ah community with a rich set of precedence. Taqīyyah provided the Shī'ah community with a strategic "system of formal and informal rules." ${ }^{, 494}$ The system guaranteed the survival of the Shī'ah community in the turbulent decades that followed the death of the eleventh Shî‘ah Imām in 874 C.E. During this period, the absence of the Shī'ah Imām and the doctrine of the "hidden Imām”495 created quite a confusion within the community. Towards the end of the ninth century C.E., according to Modarresi Tabatabaii, many Shī‘ah Muslims had already

\footnotetext{
${ }^{493}$ The majority of the reported interactions between these last three Imāms and the community are of financial nature. Religious and spiritual matters were generally delegated to the representatives of the Imāms. An excellent summary can be found in Modarresi Tabatabaii, Hossein. Maktab dar Farāyand Takāmul. pp. 43-53. See also Modarresi Tabatabaii, Hossein. Crisis and Consolidation in the Formative Period of Shi 'ite Islam.

${ }^{494}$ See Onuf, Nicholas. (1998). Constructivism: A User's Manual. In V. Kubálková, N. Onuf, \& P. Kowert (Eds.), International Relations in a Constructed World (pp. 58-78). Armonk: M.E. Sharpe.

${ }^{495}$ See Chapter I and the following Chapter.
} 
grown doubtful of their Shī‘̄i beliefs and some had already left Shī'ah Islam for other Muslim denominations. ${ }^{496}$ One of the dynamics that seems to have protected the community from extinction was the theoretical and practical contributions of the Shī'ah theologians and jurists in the decades that followed the death of the eleventh Imām. Their efforts were two-fold. On the purely theoretical level, the jurists and theologians elaborated upon various Shī‘ $\overline{1}$ doctrines in theology (including the notions of Wilāyah and Walāyah) and in jurisprudence. ${ }^{497}$ On the practical level, however, these emerging religious leaders of the Twelver Shī'ah community continued the practice of Taqiyyah. They observed expediency and caution ${ }^{498}$ not only in dealing with the Sunn̄̄ -Abbasidcaliphate, but also in responding to the rise of other branches of Shī'ah Islam ${ }^{499}$ to power. The habit of political prudence eventually helped the Twelver Shī'ahs to survive the "great bewilderment" and to begin to grow in number once again during the tenth century C.E.

Given the flexibility of the doctrine of Taqiyyah, it is difficult to overlook the powerful forces that this doctrine could release. As Enayat argues, Taqīyyah and its

\footnotetext{
${ }^{496}$ See Modarresi Tabatabaii, Hossein. Maktab dar Farāyand Takāmul. pp. 158-9; and Ibid. p. 183-7. Shī'ah sources call this period the age of "great bewilderment" among Shī'ah Muslims; for many had become uncertain about the existence of the -hidden- twelfth Imām [see Ibid p. 186-7; 'Allāmih Majlisī, Bihār al-Anwār, Vol. 51, p. 109; Ibid. Vol. 51, p. 118; and Ibid. Vol. 51, p. 142].

${ }^{497}$ See Modarresi Tabatabaii, Hossein. Maktab dar Farāyand Takāmul. pp. 188-99.

${ }^{498}$ Enayat refers to "Sh̄̄' $\overline{1}$ ' extreme caution in accepting responsibility for the administration of justice," which might have been an example of this attitude. See Enayat, Hamid. Modern Islamic Political Thought. p. 27.

${ }^{499}$ This includes the Ismā‘ $1 \overline{1}$ Fățimid dynasty (909 - 1171 C.E.) in North Africa and the -Zaydī- Būyid dynasty in Persia (932 - 1062 C.E.) [see Feirahi, Davoud. Tärīkh Tahawwūl Duwlat dar Islām. pp. 283334; and also Bosworth, Clifford Edmund. (1996). The New Islamic Dynasties. New York: Columba University Press. pp. 63-5; and Ibid. pp. 154-7].
} 
underlying expediency can be used and have been used as a pretext to violate other $\operatorname{Sh}^{`}{ }^{`} \overline{1}$ principles. ${ }^{500}$ To address this challenge, Shī'ah jurists have tried to clarify the legal boundaries of Taqiyyah, its conditions, and its limits some of which have been discussed above. Arguably the most important counterforce to Taqiyyah, however, emerged in the Shī'ah historiography of the life of the first Imām, 'Alī ibn Abī Țālib. In the following section, a brief review of this historiography and the resulting paradigm of "principled action" will be discussed.

\section{Principled Action and Expediency: The Legacy of 'Alī}

After the Prophet, 'Al̄̄ ibn Abī Țālib is the most important religious figure in Shī'ah Islam. It may be argued, in fact, that Shī'ah Islam is based on 'Alī’s understanding of the teachings of the Prophet. It is not surprising, therefore, that 'Alī's life and the traditions attributed to him play a central role in shaping Shi`‘ 1 strategic cultures. ${ }^{501}$ The legitimizing influence of his "twenty-five year silence" on the doctrine of Taqīyyah has already been discussed above. In this section, another political legacy of 'Alī will be reviewed -a legacy that is arguably the most important political tradition associated with him in Shī‘ah Islam.

\footnotetext{
500 See Enayat, Hamid. Modern Islamic Political Thought. pp. 177-80.

${ }^{501}$ There are few good sources in English dealing with the life and the teachings of 'Alī ibn Abī Țālib. This is in part due to the fact that the focus of Islamic Studies has traditionally been on Sunnī Islam. More recently, however, there have been several insightful contributions to address the dearth of knowledge about this early Muslim figure in the West. See, for instance, Shah-Kazemi, Reza. (2006). Justice and Remembrance: Introducing the Spirituality of Imam 'Alī. New York: I.B.Tauris \& Co. Ltd; Shah-Kazemi, Reza. (2011). Spiritual Quest: Reflections on Qur'anic Prayer According to the Teaching of Imam 'Alī. New York: I.B.Tauris \& Co. Ltd; and Lakhani, M. Ali. The Sacred Foundations of Justice in Islam.
} 
The mainstream understanding of the Shī'ah-Sunnī split underlines the political dispute over the succession of the Prophet. In the "Orientalist" account of the "roots of Shī'ah Islam," consequential theological differences between the two versions of the religion are often put aside. Yet, it seems that 'Alì's political career either as a "silent protestor" or, later on, as a caliph had its roots in his more esoteric understanding of Islam. It is not surprising, therefore, that 'Alī's political approach had an immediate impact on Shī’ah political philosophies.

During the rule of the first three caliphs, ${ }^{502}$ 'Alī did not endorse their legitimacy as the successor of the Prophet. ${ }^{503}$ As discussed before, however, he refused to openly challenge the first three caliphs; and on certain occasions he provided them with his consultations. According to Shī'ah historiography, "Alī's "silent protest" and reluctant accommodation during this period was an act of "sacrificing" his own political right for the sake of the long-term interests of the Muslim community. In other words, by abstaining from a "devastating revolt" against these caliphs, "Alī practiced political expediency for the "greater cause" of the survival of Islam.

In contrast, during his rather short tenure as the fourth caliph ${ }^{504}$, 'Ali appeared as what can be called a full-fledged "principlist," or someone who acts in accordance to his

\footnotetext{
${ }^{502}$ This period includes the caliphate of Abū Bakr (632 - 634 C.E.), 'Umar ibn al-Khaț̣āa ( 634 - 644 C.E.), and 'Uthmān ibn 'Affān (644 - 656 C.E.). According to the Sunnī historiography 'Alī -reluctantly or otherwise- accepted the three caliphs preceding him [see, for instance, Muhammad ibn Jarīr al-Tabarī, Tārīkh al-Ṭabarī, Vol. 2, p. 448; and Abū Muḥammad ibn Qatibah al-Daynūrī, al-Imāmah wal-Sìyāsah, Vol. 1, pp. 30-2].

${ }^{503}$ See, for example, 'Alī ibn Abī Țālib, Nahj al-Balāghah, Sermon 3; and Ibid. Sermon 77. According to the mainstream Shī'ah historiography, 'Alī did not accept the political legitimacy of the first three caliphs "even for an hour" [see Shaykh al-Mufīd, al-Fușül al-Mukhtārah, p. 56].

${ }^{504} 656-661$ C.E.
} 
principles regardless of the political consequences. Both Sunnī and Shī'ah sources report his peculiar and uncompromising approach in politics. As the caliph, 'Alī consciously refused to put politics above his "principles." For his disregard for political expediency, 'Alī has been both admired and criticized. He has been admired, mostly by Shī'ah writers, as a "true" companion of the Prophet who remained faithful to the teachings of the Prophet. After all, according to Shī'ah theology, 'Alī was the bearer of the "sacred and supreme Knowledge," or Wilāyah and Walāyah, after the Prophet. As the head of the Muslim community, therefore, "Alī could have not compromised his "sacred principles." According to the $\operatorname{Sh}^{`}{ }^{`} \overline{1}$ perspective, it was precisely his tradition of "principled action" that differentiated "Alī's "legitimate" caliphate from that of the first three caliphs.

Several episodes in 'Alī's political career, in particular, manifests his uncompromising adherence to the paradigm of "principled action." One early indication of his political philosophy may be found in his behavior as a member of the Council, known as the Shawrā, responsible for selecting the third caliph. This electoral Council was created after the assassination of 'Umar ibn al-Khațāâ, the second caliph, and according to his instructions. ${ }^{506}$ Appointed by 'Umar ibn al-Khaț̣āb, 'Alī and five other senior members of the Muslim community ${ }^{507}$ were to select the next caliph. The deliberations of the Council resulted in a final choice between 'Alī or 'Uthmān ibn 'Affān

\footnotetext{
${ }^{505}$ The use of the term "principled action" instead of the rather problematic terms "principlism" and "principlist" was first suggested to me by Professor Farhang Rajaee [F. Rajaee, personal communication, July 7, 2011].

${ }^{506}$ See, for instance, Muhammad ibn Jarīr al-Ṭabarī, Tārīkh al-Ṭabarī, Vol. 3, pp. 292-302.

${ }^{507}$ Similar to 'Alī, these were some prominent disciples of the Prophet, namely 'Uthmān ibn 'Affān, 'Abd al-Raḥmān ibn 'Awf, Zubayr ibn 'Awwām, Țalḥah ibn 'Ubaydullāh, and Sa'd ibn Abī Waqqāṣ.
} 
to be the successor of 'Umar ibn al-Khatțāb. According to the Shī'ah historiography, the Council asked 'Al̄̄ and 'Uthmān ibn 'Affān whether they would follow "the Book of God, the tradition of the Prophet, and the examples of the two previous caliphs."508 'Uthmān ibn 'Affān gave an unqualified affirmative response; and 'Alī confirmed that he would follow the Qur'ān and the tradition of the Prophet, or Sunnah, while remaining quiet about his loyalty to "the examples of the two previous caliphs." 509 The Council, then, selected 'Uthmān ibn 'Affān as the caliph. 'Alī's refusal to practice Taqīyyah in responding to the Council even though the stakes were noticeably high was later on interpreted by Shī'ah commentators as an example of "principled action."

When elected the caliph, 'Alī appeared even more stringent in his adherence to his principles. One may even argue that this uncompromising approach in politics eventually caused 'Alī to lose his control over a large part of the Muslim world. During his reign as the fourth caliph, 'Alī had three major military engagements one of which caused an irrecoverable split in the Muslim world and paved the way for the rise of the Umayyad dynasty. 'Alī's first major war, the Battle of Jamal, was with a well-known group of people associated directly to the Prophet. These included 'Āyishah bint Abī Bakr, one of the wives of the Prophet, and Zubayr ibn 'Awwām and Ṭalḥah ibn 'Ubaydullāh, two of the esteemed companions of the Prophet. While Zubayr ibn 'Awwām and Talhah ibn 'Ubaydullāh were among the first who pledged their allegiances to 'Alī as the caliph ${ }^{510}$, they gradually grew discontented with him. According to the Shī'ah historiography, the

\footnotetext{
${ }^{508}$ See Aḥmad ibn Abī Ya'qūb, Tārīkh Ya'qūbì. Vol. 2, p. 162.

${ }^{509}$ Ibid.

${ }^{510}$ See Ibid. Vol. 2, p. 178.
} 
breaking point was reached when 'Alī refused to accommodate their political wishes and, in particular, to appoint them as his governors. ${ }^{511}$ 'Alī's treatment of his fellow disciples, Zubayr ibn 'Awwām and Ṭalhah ibn 'Ubaydullāh, has often been understood as another example of "principled action." By declining the requests of the influential companions of the Prophet, 'Alī alienated them and activated several destructive dynamics against his rule. $^{512}$ The Battle of Jamal was the first major war between two prominent groups of Muslims. ${ }^{513}$ As discussed in the preceding Chapter, this Muslim "civil war" proved to

\footnotetext{
${ }^{511}$ The Sunnī account of the causes of discontent that 'Āyishah bint Abī Bakr, Zubayr ibn 'Awwām, and Talhah ibn 'Ubaydullāh felt towards 'Al̄̄ emphasizes their demand for punishing those responsible in the murder of 'Uthmān ibn 'Affān, the third caliph. 'Āyishah bint Abī Bakr, Zubayr ibn 'Awwām, and Ṭalhạh ibn 'Ubaydullāh, as well as Mu'āwīyah ibn Ab̄̄ Sufyān, maintained that the accomplices in the murder of 'Uthmān ibn 'Affān had been left unpunished. They urged 'Alī to remove his "protection of the murderers" and to prosecute them. 'Alī, on the other hand, rejected the accusations. In response, Shī'ah sources accuse Țalhah ibn 'Ubaydullāh, 'Āyishah bint Abī Bakr, and 'Amr ibn al-'Āṣ, who was Mu'āwīyah ibn Abī Sufyān's chief commander and his close confidant, of being responsible for agitations that led to the murder of 'Uthmān ibn 'Affān [see Muhammad ibn Jarīr al-Ṭabarī, Tārīkh al-Ṭabarī, Vol. 3, pp. 399-425; Ibn alAthīr, al-Kāmil fìl-Tārīkh, Vol. 3, p. 286; Aḥmad ibn Abī Ya'qūb, Tārīkh Ya 'qūbī. Vol. 2, pp. 174-6; Abū Muḥammad ibn Qatibah al-Daynūrī, al-Imāmah wal-Sìyāsah, Vol. 1, pp. 56-63; Aḥmad ibn A'tham al-Kūfī, Kitāb al-Futūh, Vol. 2, p. 393; Ibid. Vol. 2, p. 417; and Ibid. Vol. 2, p. 421. See also 'Alī ibn Abī Ṭālib, Nahj al-Baläghah, Sermon 22; Ibid. Sermon 137; and Ibid. Sermon 174 in which "Alī complains that "those responsible for 'Uthmān [ibn 'Affān]'s death have disguised themselves as the champions of his revenge"]. Historically, no one was tried for the murder of 'Uthmān ibn 'Affān, either under 'Alī's reign or that of Mu'āwīyah ibn Ab̄̄ Sufyān.
}

In regards to Zubayr ibn 'Awwām's and Ṭalḥah ibn 'Ubaydullāh's political aspirations and specifically their demands to be appointed as the governors of Kūfah and Bașrah, see 'Alī ibn Abī Țālib, Nahj al-Balāghah, Sermon 148; Muḥammad ibn Jarīr al-Ṭabarī, Tārīkh al-Ṭabarī, Vol. 3, p. 459; Abū Muḥammad ibn Qatibah al-Daynūrī, al-Imāmah wal-Sīyāsah, Vol. 1, p. 70; and Feirahi, Davoud. Tārīkh Tahawwwūl Duwlat dar Islām. p. 194.

${ }^{512}$ It is reasonable to believe that had 'Alī acquiesced to political ambitions of Zubayr ibn 'Awwām and Țalhah ibn 'Ubaydullāh, he could have prevented the Battle of Jamal and the great confusion it caused within the Muslim society. It was arguably the aftershocks of the Battle of Jamal that deprived 'Ali of a decisive victory in the Battle of Șiffin. This, in turn, led to the split of Khawārij from 'Alī's army, the consequent Battle of Nahrawān, and eventually the assassination of 'Alī by a member of Khawārij.

${ }^{513}$ For the early historical accounts of the Battle of Jamal, see Muhammad ibn Jarīr al-Tabarī, Tärīkh alTabarī, Vol. 3, pp. 465-545; Ibn al-Athīr, al-Kämil fìl-Tārīkh, Vol. 3, pp. 205-59; and Aḥmad ibn Abī Ya'qūb, Tārīkh Ya'qūibì. Vol. 2, pp. 181-3. 
have had lasting legacies - one of which was the consequential Battle of Șeffin between the army of 'Alī and that of Mu'āwīyah ibn Abī Sufyān.

The Battle of Șiffin was the culmination of a series of tensions between 'Alī, the caliph, and Mu'āwīyah ibn Ab̄̄ Sufyān, then governor of al-Shām. Appointed by caliph 'Umar ibn al-Khațtāb, in 640 C.E., Mu'āwīyah ibn Abī Sufyān had managed to establish and consolidate his rule over that strategic territory prior to 'Alī's caliphate. Using his political shrewdness over a long tenure of governorship, Mu'āwīyah ibn Abī Sufyān had cultivated the loyalty of powerful figures in al-Shām. ${ }^{514}$ In one of his first edicts as the fourth caliph, 'Alī removed Mu'āwīyah ibn Ab̄i Sufyān from the position of governorship. ${ }^{515}$ Not surprisingly, Mu'āwīyah ibn Abī Sufyān defied and questioned the legitimacy of 'Alī's caliphate by accusing him of "sheltering the murderers of 'Uthmān ibn 'Affān." Eventually, the two sides came to a military conflict in the region of Șiffīn that ended in an inconclusive arbitration. The war resulted in bifurcation of the Muslim world and severely weakened 'Alī's hold on power. It also gave birth to a group of bitter “extremists," Khawārij" ${ }^{516}$, who broke away in 657 C.E. Khawārij protested 'Alī's handling of the Battle of Șiffìn and eventually assassinated him in 661 C.E. ${ }^{517}$

'Alī's uncompromising treatment of Mu'āwīyah ibn Abī Sufyān and his refusal to renew his tenure as the governor were understood by Shī'ah Muslims as manifestations

\footnotetext{
${ }^{514}$ For a concise yet helpful account of this period see Armstrong, Karen. (2002). Islam: A Short History. New York: Random House.

${ }^{515}$ See Ibn al-Athīr, al-Kāmil fìl-Tārīkh, Vol. 3, p. 201.

${ }^{516}$ See Chapter II.

${ }^{517}$ For the early historical accounts of the Battle of Șiffīn and its consequences, see Muhammad ibn Jarīr alȚabarī, Tārīkh al-Tabarī, Vol. 3, pp. 562-71; Ibid. Vol. 4, pp. 2-52; Ibn al-Athīr, al-Kāmil fïl-Tārīkh, Vol. 3, pp. 276-315; and Aḥmad ibn Abī Ya'qūb, Tārīkh Ya 'qūbì. Vol. 2, pp. 187-90.
} 
of his paradigm of "principled action." Once again, had 'Alī extended Mu'āwīyah ibn Abī Sufyān's governorship, he could have arguably spared his caliphate from the second devastating Muslim "civil war." ${ }^{\text {, }} 18$ Yet, he unequivocally expressed his opposition to Mu'āwīyah ibn Abī Sufyān as a "matter of principles" "519 and justified his disregard for political expediency, or "shrewdness," i.e. Dahā'. In a sermon, 'Alī asserts that “by God, Mu'āwīyah [ibn Abī Sufyān] is not shrewder than I am; but [his shrewdness is because] he perpetrates acts of deception and evil. Had it not been for my despising of deceit and guile, I would have been the shrewdest of all people. But, in fact, every act of deceit is an act of great evil; and, as such, an affront to God. And it is [destined] for every deceitful man to carry a banner [of shame] to be recognized in the Day of Judgment.

By God, his [i.e. Mu‘āwīyah ibn Abī Sufyān's] wicked ploys will not cause me to become forgetful [of my obligations towards God by committing the same evil]; and [even though this will cause me hardships] I will not be overwhelmed by the difficulties.",520

\footnotetext{
${ }^{518}$ According to Muhammad ibn Jarī al-Ṭabarī, Mughayrah ibn Shu'bah, who was one of the companions of the Prophet, tried in vain to dissuade 'Alī from removing Mu'āwīyah ibn Abī Sufyān at that time. He argued that by immediately replacing powerful figures such as Mu'āwīyah ibn Abī Sufyān, "Alī would endanger the future of his caliphate. He even urged "Alī to keep "all governors" of 'Uthmān ibn 'Affān in their position until "Alī would consolidate his hold on power and would ensure the loyalty of his army. After such a transition period, Mughayrah ibn Shu'bah says to "Alī, "you may replace them or leave them to govern" [see Muhammad ibn Jarīr al-Ṭabarī, Tārīkh al-Tabarī, Vol. 3, p. 459; and also Feirahi, Davoud. Tārīkh Tahawwūl Duwlat dar Islām. p. 194].

${ }^{519}$ For 'Alī’s position on Mu'āwīyah ibn Abī Sufyān's governorship and some of his letters to Mu'āwīyah ibn Abī Sufyān, see 'Alī ibn Abī Țālib, Nahj al-Balāghah, Letters 6, 7, 9, 10, 17, 28, 30, 32, 37, 48, 49, 55, 64, 65, 73, and 75. See also Abū Muḥammad ibn Qatibah al-Daynūrī, al-Imāmah wal-Sìyāsah, Vol. 1.

${ }^{520}$ See Ibid. Sermon 200.
} 
Throughout Shī'ah history, "Alī's paradigm of "principled action" has become the hallmark of his political philosophy. In particular, his legacy of "principled action" has served as paradigm against unrestricted use of expediency in Shī' ${ }^{\prime} \overline{1}$ strategic cultures. The fact that the patriarch of Shī'ah Islam refused to be politically expedient to the extent that it cost him his caliphate and indeed his life has been a source of aspiration throughout Shī'ah history and especially for those Shī'ahs who have not been comfortable with the implications of the doctrine of Taqīyyah. ${ }^{521}$

To better understand the significance of the paradigm of "principled action" in Shī'ah Islam, it is worth briefly reviewing its powerful comeback after the Islamic Revolution of 1979 in Iran. As Mesbahi argues, the newly established state in Iran had to struggle with a wide range of theoretical and practical challenges. ${ }^{522}$ Mesbahi claims that the new Shī'ah state dealt with these challenges by employing the paradigm of political expediency which, as discussed above, is at the heart of the doctrine of Taqiyyah. It was

\footnotetext{
${ }^{521}$ One of the important articulations of "Alī's paradigm of "principled action" may be found in "Alī ibn Abī Țālib, Nahj al-Balāghah, Letters 53. This is a letter written by "Alī to his appointed governor of Egypt, Mālik al-Ashtar al-Nakha'ī. Along with the so-called "Medina Constitution," "Alī's letter is among the important ancient documents in Shī'ah political philosophy. In the letter, "Alī expounds upon what constitutes "good governance" in his opinion. It is a coherent and forceful argument that stands in a stark contrast with -at least any generous- practice of political expediency. Interestingly, however, "Alī formulates his paradigm of "principled action" as a kind of "ultimate consequentialism." He does so by adding the metaphysical dimension into the chain of causes and effects. In any case, even though after the Prophet, 'Alī is the most celebrated figure among Shī'ah religious and political establishment, this letter appears to have been of limited influence. See Homayounvash, M., \& Mirtaheri, S. A. (Forthcoming 2012). Honoring Contracts as a Foundation of Peace: A Shī'ah Articulation. Journal of Religion, Conflict and Peace. See also Reza Shah-Kazemi's essay on "A Sacred Conception of Justice: Imam 'Ali's Letter to Malik al-Ashtar" in Lakhani, M. Ali. The Sacred Foundations of Justice in Islam. pp. 61-108. For the text of the "Medina Constitution" see Ibn Hishām, Sìrah al-Nabawìyyah, Vol. 2, pp. 348-51.

${ }^{522}$ Analyzing the challenge posed by the institution of modern nation-state -in the Muslim world in general and in the Shi' ${ }^{`}$ ah world in particular-goes beyond the scope of this dissertation. This challenge, however, may affect the eventual manifestations of various Shī‘ 1 strategic cultures in different ways [M. Mesbahi, Lectures, Fall 2007, and M. Mesbahi, Interviews, Fall 2011].
} 
in response to the extensive use of political expediency by the state that the paradigm of "principled action" made its forceful return in the political career of Ayatollah Muntazirī.

A senior student and close companion of Ayatollah Khomeini, Ayatollah Muntaẓirī was a highly venerated figure among the revolutionaries in 1979 . He was generally respected by other usually more junior leaders of the Revolution, many of whom were Ayatollah Muntazirî’s former students. Given his status, in the early 1980s, Ayatollah Muntazirī was appointed as the future successor of Ayatollah Khomeini by the Iranian "Assembly of Experts." ${ }^{, 523}$ Moreover, as a Shī‘ah jurist universally admired for his extent of knowledge and his jurisprudential skills, Ayatollah Muntazirī wrote arguably the most powerful Shī'ah treatise in support of Wilāyat Faqīih. ${ }^{524}$

Despite his high stature within the political establishment and among Shī'ah jurists, Ayatollah Muntazirī publicly voiced his criticism of what he perceived as "too generous" employment of political expediency at the costs of Shī'i "principles." $\mathrm{He}$ refused to condone certain actions by the government especially in regards to the treatment of political prisoners; and he did so based on religious arguments. In fact, similar to 'Alī, he refused to allow raison d'état to play any significant role in his political

\footnotetext{
${ }^{523}$ In Iran's complicated bureaucratic system, the "Assembly of Experts" is the elected body of high-rank "Ulamā responsible, according to the Constitution, for supervising and electing the leader in the Islamic Republic of Iran.

${ }^{524}$ Wilāyat Faqīh is the foundational theory behind the Iranian state that emerged after the Revolution. The term has often been translated as "Guardianship or Supervision of Jurist." For some more discussion of the theory of Wilāyat Faqīh and the relevant notions of Wilāyah and Walāyah in Shī'ah Islam, see the following Chapter.
}

Ayatollah Muntazirirìs multi-volume book on Wilāyat Faqīh, Dīrāsāt fì Wilāyah al-Faqīh, is in Arabic. The book is written in the same legalistic tradition of classical Shī'i treatise using jurisprudential methodology and the Science of Principles -i.e. 'Ilm al-'Ușūl- to religiously justify the "truth of the theory of Wilāyat Faqīh." Ayatollah Muntazirī's formulation of the theory, however, shows a consequential difference with that of Ayatollah Khomeini. The former articulation is dryly legalistic while the latter's approach to Wilāyat Faqīh is unreservedly esoteric. 
judgments. As a result, the tension between him and the office of Ayatollah Khomeini gradually rose. Eventually, this tension culminated in Ayatollah Muntazirī̄'s removal from his position just month before Ayatollah Khomeini's death. Ayatollah Muntazirī's students and followers usually interpret the episode as the testimony to Ayatollah Muntazirī’s adherence to the paradigm of "principled action," for according to them, Ayatollah Muntazirī who was aware of the deteriorating health of Ayatollah Khomeini, refused to remain silent for a few months and walked away from the most powerful seat in the country without hesitation. ${ }^{525}$

Following the death of Ayatollah Khomeini, Ayatollah Muntazirī continued his uncompromising political approach and showed little concern for immediate consequences. He challenged the newly elected leader, Khamenei, in a similar fashion and by resorting to essentially Shī‘̄i arguments. He repeatedly advocated a return to what he believed to be the religious principles of Shī'ah Islam. Prime among such principles, Ayatollah Muntazirī believed, was the notion that political and social injustice should be protested at any cost. Because of his open and direct criticism of the leader of the country, he was eventually put under house arrest, which lasted for several years. When he died in 2010, Ayatollah Muntazirī had already become the modern icon of the Shī's paradigm of "principled action" in Iran. ${ }^{526}$

\footnotetext{
${ }^{525}$ In response to Ayatollah Muntazirī's criticism, the Iranian state resorted to the notion of expediency. As Mesbahi notes, this was to establish, arguably for the first time in Sh'`'ah history, a full-fledged religious articulation of raison d'état. The state dismissed Ayatollah Muntazirī's criticism as "naïve arguments" that do not take into account the complex realities of politics [M. Mesbahi, Interviews, Fall 2011 \& Spring 2012]. In fact, in the official state propaganda, Ayatollah Muntazirī was derogatorily labeled as the "naïve Shaykh."

${ }^{526}$ The significance of Ayatollah Muntazirī's "school of thought" in political philosophy and especially in relation to the doctrine of Taqiyyah became clear to me through my personal communications with
} 


\section{CHAPTER V}

\section{WILĀYAH AND WALĀYAH: A SHĪ'AH ONTOLOGY}

\section{Understanding Wilāyah and Walāyah}

The reader may have noticed throughout the preceding Chapters that the notions of Wilāyah and Walāyah ${ }^{527}$ lie at the heart of Shī'ah theology. It is, in fact, one of the central claims of my dissertation that unless taking these two notions into account, one cannot fully explain the differences between Shī'ah Islam and Sunnī Islam. In terms of Shī‘̄i strategic cultures, Wilāyah and Walāyah are the theological concepts upon which the doctrines of Shahādah and Taqīyyah rely. As discussed before, Shī'ah theologians strived to achieve a balance between Shī's "ideals" and the practical concerns. On the one hand, the story of Ḥusayn in Karbalā seemed to suggest fulfilling one's -religious- duties regardless of worldly consequences. As a result, the doctrine of Shahādah highlighted the "metaphysical dimension" of human existence in which death and physical insecurity

Professor Mohsen Kadivar during September 2010. See also Mohsen Kadivar's articles on various aspects of "Muntazirī school of thought" on www.kadivar.com [retrieved on February 29, 2012].

527 The Arabic words Wilāyah and Walāyah come from the Arabic root $w-l-y$ (i.e. Jول). According to Wehr's Arabic-English Dictionary, w-l-y means, inter alia, "to be near"; "to be a friend"; "to be in charge"; "to rule"; "to have authority"; "to be a patron"; "to assume the responsibility"; and "to follow in succession." The word Wilāyah in particular means "sovereign power," "rule," and "authority." The word Walāyah -and its other common form, Walā'- means "to be a friend," "friendship," "guardianship," "curatorship," as well as "devotion," "loyalty," and "clientage." In addition, both Wilāyah and Walāyah mean "to be in charge" and "to have authority." The word Walāyah appears in the Qur'ān in the verse 8:72 where it means "friendship" or "protection," and in the verse 18:44 where it means "protection." The word Wilāyah does not appear in the Qur'ān. Other derivatives of the root $w-l-y$-especially the word Walī meaning someone who possesses Wilāyah or Walāyah- appear in the Qur'ān quite a number of times [see, for instance, $2: 107,120,257,282 ; 3: 28,68,122,175 ; 4: 45,75,76,89,119,123,139,144,173 ; 5: 51,55$, $57,81,107 ; 6: 14,51,70,121,127,128 ; 7: 3,27,30,155,196 ; 8: 34,40,72,73,75 ; 9: 23,71,74 ; 10: 62$; $11: 20,113 ; 12: 101 ; 13: 16,37 ; 16: 63 ; 17: 33,97,111 ; 18: 17,26,50,102 ; 19: 5,45,70 ; 22: 13,78 ; 25: 18$; $27: 49 ; 29: 22,41 ; 32: 4 ; 33: 6,17,65 ; 34: 41 ; 39: 3 ; 41: 31,34 ; 42: 6,8,9,28,31,44,46 ; 44: 41 ; 45: 10,19$; $46: 32 ; 47: 11,20 ; 48: 22 ; 60: 1$; and $62: 6]$. As will be further elaborated upon, in Shī'ah theology, Wilāyah and Walāyah respectively refer to the exoteric and esoteric aspects of the "metaphysical structure" of the universe around which the world is organized, and through which the Grace of God is believed to be bestowed upon man. 
appeared trivial. The doctrine broadened the meaning of survival to encompass the "blissful and eternal state" of those who dismiss the fear of death for a "holy cause." On the other hand, the same events of Karbalā gave birth to a cautious "pragmatism," which emphasized the necessity of protecting an "invaluable yet vulnerable community." The fate of Husayn reminded early Shī'ah Muslims that the only alternative to recklessness and oblivion might be extinction. What happened to the Shī' ah Imāms who followed Husayn only added to this sense of vigilance. Even though most if not all of these Imāms were politically cautious ${ }^{528}$ and avoided the type of open political encounter that Husayn had had, they ended up being imprisoned and/or poisoned. ${ }^{529}$ Consequently, the Shī'ah Imāms condoned certain measures of prudence in order to protect the survival of the Shī'ah community and that of Shī'ah individuals. At the same time, none of the Shī'ah Imāms -and indeed no single Shī‘ah theologian or jurist throughout Shī'ah history- has failed to praise Husayn and his "heroic deeds" in Karbalā as an ultimate example of religious sacrifice -and "utmost salvation."

In certain ways the above tension between the "ideals" and the reality reminds one of a similar dynamic within Hinduism. While dharma emphasizes one's

\footnotetext{
${ }^{528}$ For a detailed discussion of "politics of Taqiyyah" and the specific manifestations of such a politics in the lives of the Shī'ah Imāms, see the preceding Chapter.

${ }^{529}$ As discussed in Chapter IV, the extent of political engagement by the Shī'ah Imāms depended upon their socioeconomic settings as well as their characters. While 'Alī ibn Abī Țālib, Husayn ibn 'Alīe Mūsā ibn Ja'far, and arguably 'Alī ibn Mūsā were politically more active, the rest were rather "quietists," e.g. 'Alī ibn Husayn, Muḥammad ibn 'Alī (the fifth Imām), or Ja 'far ibn Muḥammad, and/or under considerable restrictions by the state, e.g. Muhammad ibn 'Alī (the ninth Imām), 'Alī ibn Muhammad, and Hasan ibn 'Alī. The second Imām, Hasan ibn 'Alī, chose the course of political "quietism" following his short-lived tenure as the caliph following the assassination of his father. This tradition of political "quietism" has survived to this day as one may observe it in the behavior of many senior Shī'ah "Ulamā residing in Najaf, Iraq. Prior to the Islamic Revelation of 1979 in Iran, political "quietism" was also the mainstream approach among most senior Shī'ah 'Ulamā living in Qum, Iran.
} 
responsibilities towards society -and towards the world-, moksha invites the believer to the "ultimate liberation of the soul." 530 Similarly, Shī'ah Muslims were urged to pay attention to their precarious situation as a community and to fulfill their responsibilities towards that community. At the same time, they were encouraged to view Husayn's fate as salvation and the "liberation of the soul" par excellence. Similar to Hinduism, therefore, it was necessary for $\mathrm{Sh}^{-}{ }^{`}$ ah theologians to reconcile powerful implications of martyrdom and the demands of preservation. The implicit solution was based on the notions of Wilāyah and Walāyah.

Wilāyah and Walāyah are two closely related concepts in Muslim theology. ${ }^{531}$ The two notions are of particular significance among two overlapping groups of Muslims, namely Shī'ah Muslims and Shī'ah and Sunnī Șūfīs. ${ }^{532}$ In the field of Islamic Studies, there has been some discussion about the delicate differences between the two terms Wilāyah and Walāyah. The discussion aims at clarifying the meanings of the two terms based on an ancient tradition of etymological discussions on Wilāyah and Walāyah among the Șuffis. ${ }^{533}$ An extensive etymological discussion, however, is beyond the scope

\footnotetext{
${ }^{530}$ See Kinsely, David R. (1993). Hinduism: A Cultural Perspective. Englewood Cliffs: Prentice Hall.

${ }^{531}$ In fact, the two terms Wilāyah and Walāyah have been often used interchangeably by scholars of Islam and even by Muslims themselves.

${ }^{532}$ For more discussion of the similarities between Shī'ah Islam and Tașawwuf, i.e. the Șūfì traditions, see various works by Henry Corbin including Corbin, Henry. (1978). The Man of Light in Iranian Sufism. London: Shambhala; and Corbin, Henry. (1986). Temple and Contemplation. London: Routledge. Following Corbin, one may argue that there is an "in-built Tașawwuf" within Shī'ah Islam. This "inherent Tașawwuf," even when left unacknowledged, brings the religious experiences of Shī'ah Muslims close to those of Suufìs according to Corbin.

${ }^{533}$ See, for instance, Cornell, Vincent J. (1998). Realm of the Saints: Power and Authority in Moroccan Sufism. Austin: University of Texas Press. Cornell uses other forms of the two terms, i.e. Wilayat and Walayat, as well [see Ibid. p. xix]. See also Enayat, Hamid. Modern Islamic Political Thought. pp. 45-6.
} 
of this dissertation. Suffice to say that Wilāyah and Walāyah respectively refer to the exoteric and esoteric aspects of a particular ontology adopted by both Shī'ah Muslims and Șūfìs. Esoterically, Walāyah refers to a metaphysical cosmology. ${ }^{534}$ It projects a spiritual hierarchy of the world or a metaphysical "system" through which the Grace of God is bestowed upon men. ${ }^{535}$ Within this context, the term Walāyah implies closeness to the "Absolute." The closer one gets to the "Foundation of all existence," the more powerful one becomes spiritually and metaphysically speaking. According to the Șūfĩ doctrines, this may result in one's turning into a channel of Divine Grace and that of Divine Providence. ${ }^{536}$ That is why Șūfī saints are traditionally called "Walīs of God," which means, inter alia, "friends of God." This terminology is believed to be sanctioned

\footnotetext{
${ }^{534}$ In fact, the esoteric dimension of Islam may be understood through the notion of Walāyah. Walāyah brings the Șüfi or the "seeker" in touch with the "Divine Essence" by means of what is usually called "initiation." Eventually, the Șūfĩ "Path" is to lead to the experience of "annihilation," i.e. Fanā, of the "seeker" within the "Divine Essence" and his or her identification with God. In Șūfì literature, therefore, the structure of Wilāyah and Walāyah covers the exoteric and esoteric aspects of the "Path" towards God. This structure manifests itself in the persons of the Imāms emphasized in Shī'ah Islam, or in Șūfĩ Shaykhs emphasized in Sunnī Șūfì traditions. These religious and spiritual authorities guide and mentor their students through the students' "inner journeys" towards God. See Lings, Martin. (1993). What is Sufism. Cambridge: The Islamic Text Society; Nasr, Seyyed Hossein. (1972). Sufi Essays. Albany: State University of New York Press; and Schuon, Frithjof. (2006). Sufism: Veil and Quintessence. Bloomington: World Wisdom.
}

${ }^{535}$ See Nasr, Seyyed Hossein. Knowledge and The Sacred. In particular, see chapter six. For related notions of the "hierarchy of being," the "hierarchy of knowledge," and the "hierarchy of existence" see Nasr, Seyyed Hossein. Sufi Essays. In terms of Islamic cosmology and the related "hierarchy of the universe," the most authoritative work is Nasr, Seyyed Hossein. (1993). An Introduction to Islamic Cosmological Doctrines. Albany: State University of New York Press. The notion of the "hierarchy of being" has been elaborated upon by various Șūfĩ writers including Ibn 'Arabī, also known as Shaykh al-Akbar (d. 1240 C.E.). Arguably the most extensive treatment of the notion can be found in the works of the prominent Shī'ah philosopher and mystic, Șadr al-Dīn Shīrāzī, also known as Mullā Șadrā (d. 1640 C.E.). His theory of Tashkīk al-Wujūd, or "Gradation of Being," is essentially based upon the notion of the "hierarchy of existence or being," which has close affinity to the notions of Wilāyah and Walāyah. See Kalin, Ibrahim. (2010). Knowledge in Later Islamic Philosophy: Mullā Sadrā on Existence, Intellect and Intuition. Oxford: Oxford University Press; and Rustom, Muhammed. (Forthcoming 2012). The Triumph of Mercy: Philosophy and Scripture in Mulla Șadrā. Albany: State University of New York Press.

${ }^{536}$ For the related notion of Barakah, or "spiritual blessings [emanated from saints]," see Nasr, Seyyed Hossein. Sufi Essays; and Schuon, Frithjof. Sufism: Veil and Quintessence. 
by the Qur'ān. ${ }^{537}$ In Shī'ah Islam, Walāyah refers to a "type of existential authority and domination [over other beings] of an extraordinary nature." ${ }^{, 538}$ Walāyah is an embedded feature of the "esoteric structure" of the world. This "esoteric structure," however, is accompanied by an exoteric manifestation, namely Wilāyah. Wilāyah refers to the structure of external authority that comes from the possession of Walāyah. In other words, the closer one gets to God, the higher becomes one's spiritual status and this, in turn, may lead to external authority. Wilāyah, therefore, is associated with more outward meanings such as guardianship, protection, and eventually political authority.

While according to Muslim theology, the ultimate Wilāyah lies with God, His Wilāyah could be manifested among humankind as well. In Shī'ah Islam, certain individuals are believed to have been granted the status of Wali in the sense of being the vessels of the Divine (exoteric) Wilāyah. To Shī'ah Muslims, these individuals include the Prophet and the Imāms, i.e. 'Alī and his eleven descendants, who are the bearers of

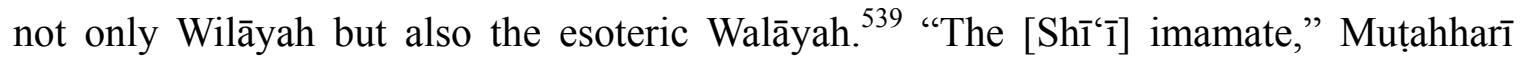

\footnotetext{
${ }^{537}$ As discussed before, the word Walī comes from the same root of $w-l-y$. Walī appears in the Qur'ān in numerous places in both single and plural forms. See above.

${ }^{538}$ See Muṭahharī, Murtạ̣ā. (2010). Walā'-hā wa Wilāyat-hā. Tehran: Ṣadrā Publications. p. 75.

${ }^{539}$ For an authoritative account of Walāyah -and Wilāyah- in Sh'̄'ah Islam, see Tabāṭabā'̄în, Sayyid Muḥammad Ḥusayn. Shi 'ite Islam. Țabāțabā'ī believes that the Qur'ānic term "Imām" refers to the bearer of Walāyah who is ultimately responsible for all the "spiritual guidance" in the world [see the verse 2:124 of the Qur'ān and Mutahharī, Murtaḍā. Walā'-hā wa Wilāyat-hā. p. 97]. In fact, in one of the classical collections of Shī'ī Hadīths, i.e. Ușül al-Kăfít, there is a section under the title of the "Imāms as the Light of God" referring to their functions as the guides for men [see Abū Ja "far Thiqat al-Islām Kuliynī, Ușūl alKăfi, Vol. 1, pp. 194-5].
}

Also, for an example of the Shì'is Șūfì literature, see Țabāṭabā'ī, Sayyid Muḥammad Ḥusayn. (2003). Kernel of the Kernel. Trans. M. H. Faghfoory. Albany: State University of New York Press. See also Nasr, Seyyed Hossein. (1985). Ideals and Realities of Islam. London: George Allen \& Unwin. Note that an important dimension of the Imāms' Walāyah is their "penetrating knowledge." Mainstream Shī'ah sources argue that the Imām's knowledge, or 'Ilm al-Imām, is of esoteric essence and, thus, extraordinary. See, for instance, Shaykh Muhammad Ḥusayn al-Muzaffar, 'Ilm al-Imām. This "extraordinary knowledge" of the 
writes, "is a type of Wilāyah, for it entails a certain degree of right to domination over, expedient administration of, and intervention in the affairs of the people., 540

Similar to the doctrines of Shahādah and Taqīyyah, the notions of Wilāyah and Walāyah in Shī'ah Islam have their roots in the Qur'ān. As indicated before, the word Walī and its plural form Awlīyā' appear many times in the Qur'ān. Several verses, however, are of particular importance when it comes to these two notions. Verse 9:71, for instance, implies that there is a hierarchy among the "believers" for some have "Wilāyah over the others." Verse 5:55 declares that the bearers of Wilāyah and Walāyah are God, the Prophet, and those believers who "perform the prayers, and pay the alms while they are bowing down [in praying to God]." The verse is sometimes called the "verse of

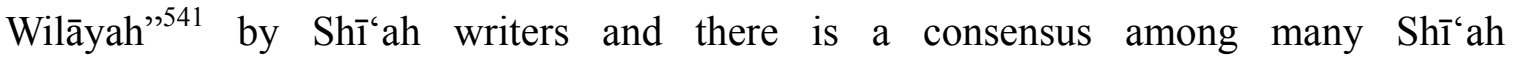
commentators that the latter part of the verse refers to 'Alī ibn Abī Țālib, the first

\footnotetext{
Imāms bring the Shī‘ī doctrine of imamate close to the Sūfì notion of al-Insān al-Kāmil, i.e. "the universal or the perfect man." See Nasr, Seyyed Hossein. (2007). The Essentials Seyyed Hossein Nasr. Bloomington: World Wisdom. pp. 65-72. For more on the philosophical-mystical mixture of Shī‘ 1 and Șūfî Islams and the resulting notion of "Wilāyah al-Takwīn̄̄," see Modarresi Tabatabaii, Hossein. Maktab dar Farāyand Takāmul. pp. 105-6. It must be added that the concept of the Imām's "extraordinary knowledge" did not go undisputed within the Shī'ah community as a group of early Shī'ah scholars challenged it. These scholars argued that the Imāms were "extremely pious and knowledgeable" individuals but denied most of the claims regarding their supernatural capabilities. This school of Shī'i thought, sometimes derogatorily called Muqașșirah or "those who have failed [in appreciating the true status of the Imāms]," seems to have been marginalized throughout history. For an extensive discussion see Modarresi Tabatabaii, Hossein. Maktab dar Farāyand Takāmul. Especially, see pp. 58-107.

${ }^{540}$ See Muțahharī, Murtaḍā. Walā'-hā wa Wilāyat-hā. p. 65. See also Shaykh al-Ṣadūq, 'Uyūn Akhbār alRidhā, Vol. 2, pp. 195-200.

${ }^{541}$ Besides these verses, Shi' 'ah scholars have often referred to the verses $2: 124,207,257,269 ; 3: 61 ; 4: 59$; $5: 3,67 ; 7: 44 ; 8: 62 ; 9: 3 ; 9: 19-22,100,119 ; 13: 7,43 ; 19: 96 ; 21: 73 ; 32: 24 ; 33: 33 ; 39: 32-4 ; 42: 23 ; 56: 10-2$; 66:4; 69:11-2; 76:5-10; and 98:7-8 to establish their claim that after the Prophet, it was 'Ali who possessed Wilāyah and Walāyah. See Shaykh Makārim al-Shirāzī, Āyāt Wilāyat dar Qur'ān.
} 
Imām. ${ }^{542}$ Therefore, they argue that the status of Wilāyah and Walāyah was transmitted from the Prophet to 'Alī.

In terms of the "Hadīth foundation" of Wilāyah and Walāyah, Shī'ah sources report several Prophetic traditions. The two traditions frequently quoted are the so-called "Hadīth of Wilāyah" and "Hadīth of Ghadīr al-Khum." Both traditions have been reported by Shī'ah and Sunnī sources, albeit with slight differences. In regard to these traditions, the main distinction between the Shī'ahs and the Sunnīs lies in their different understandings of the implications of the two Hadiths. According to the "Hadith of Wilāyah," the Prophet has declared that "Alī will be the Walī of every believer after me [i.e. the Prophet]." ${ }^{543}$ Sunn̄̄ commentators view this narration as a special praise of 'Alī by the Prophet in response to some criticism raised against 'Alī. ${ }^{544} \mathrm{Sh}^{`}$ 'ah commentators,

\footnotetext{
${ }^{542}$ See, for instance, Shaykh al-Ṭūsī, al-Tibyān fì Tafsìr al-Qur 'ān, Vol. 3, p. 561; and 'Allāmih Ṭabāṭabā'ī, al-Mīzān fì Tafsìr al-Qur'ān, Vol. 6, pp. 5-25. In his rather long commentary upon the verse, 'Allāmih Țabātabā'̄i articulates the mainstream Sh'̄'ī understanding of Wilāyah and Walāyah based on the Qur'ānic verses as well as the Shī'ah body of Hadīth. Note that 'Allāmih Țabătabā'̄ uses the term Wilayyah alTakwīn, or "Wilāyah of Formation or Origination," to refer to what is called Walāyah in this dissertation [see Ibid. Vol. 6, p. 13]. See also Amīn al-Islām Țabarsī, Kitāb al-Ihtijāj, Vol. 1, p. 161; and Ibid. Vol. 1, p. 197. Several Sunnī commentators have also reported that the above verse was first revealed in reference to 'Alī [see, for instance, Sa'd al-Dīn Taftāzānī, Sharh al-Maquassid fì 'Ilm al-Kalām, Vol. 2, pp. 288-9; Mīr Sayyid Sharīf Jurjānī, Sharh al-Mawāqif, Vol. 8, p. 360; and 'Abd al-Raḥmān ibn Abī Bakr al-Suyūṭ̂̄, alDurr al-Manthūr fìl-Tafsīr bil-Ma 'thūr, Vol. 2, p. 294. See also Qāḍī 'Aḍid al-Dīn İj̄ì, al-Mawāqif fì 'Ilm alKalām; and Maḥmūd al-Ālūsī, Rūh al-Ma 'ānī fi Tafsìr al-Qur'ān al-'Az̄ìm wal-Sab' al-Mathānī]. For related reports, see Abū al-Qāsim Zamakhsharī, al-Kashshāf 'an Haqū'iq al-Tanzīl wa 'Uyūn al-Aqāwīl fi Wujūh al-Ta'wīl, Vol. 1, p. 623; and Fakhr al-Dīn Rāzī, Tafsìr al-Kabìr, Vol. 12, p. 26.

${ }^{543}$ This Hadīth has been reported in various sources including Muhammad al-Tirmadhī, al-Ṣahīh, Vol. 5, pp. 296-7; Aḥmad ibn Ḥanbal, al-Musnad, Vol. 4, pp. 437-8; 'Alā al-Dīn 'Alī al-Hindī, Kanz al- 'Ummāal fì Sunan al-Aqwāl wal-Af'āl, Vol. 11, p. 608. See also Muhammad ibn Ismā‘īl al-Bukhārī, al-Ṣahīh, Vol. 5, p. 85.
}

${ }^{544}$ According to Sunnī sources, quite a number of the praises of 'Alī attributed to the Prophet were issued in defense of the former against various criticisms. This indicates that even at the time of the Prophet, some tension existed between 'Alī and some of his fellow disciples. In fact, 'Alī appears to be a rather polarizing figure in the early history of Islam. Often, a small group of prominent disciples including Salmān al-Fārsī, Abūdhar al-Ghifārī, and Miqdād ibn Aswad are cited as close friends of 'Al̄̄ [see Muhammad al-Tirmadhī, al-Sahīh, Vol. 5, p. 299]. For a Shī'ī account of 'Alī’s character, see Muțahharī, Murtaḍā. (1989). Jädhibih wa Dāfi 'ih 'Alī. Tehran: Șadrā Publications. See also Muḥammad al-Tirmadhī, al-Ṣaḥịh, Vol. 5, pp. 296- 
in contrast, interpret the tradition as a clear indication that 'Alī was declared as the future bearer of the Prophetic Wilāyah and Walāyah. ${ }^{545}$

"Hadīth of Ghadīr al-Khum" refers to another Prophetic tradition reported by both Sunnī and Shī'ah sources. ${ }^{546}$ The Hadīth is arguably the most frequently quoted Hadīth by the Shī'ah sources in regard to their argument about 'Alī's Wilāyah and Walāyah. According to the narration, in the year 632 C.E., the Prophet performed his last pilgrimage to Mecca - often called the "Farewell Pilgrimage." ${ }^{, 547} \mathrm{He}$ was accompanied by a large number of Muslims from various regions of the Arabian Peninsula. After the conclusion of the rituals and before the many caravans departed for their hometowns, the Prophet summoned all to gather in a place called Ghadīr al-Khum, the Pond of Khum, and gave a sermon. Then, according to Shī'ah sources, he raised the hand of 'Alī and declared that "to whomever I have been the Mawlā[ $\left.{ }^{548}\right]$, 'Alī here is to be his Mawlā.,"549

306. The fact that 'Alī had no strong tribal support within Quraysh was also a factor in the emergence of the forces against him, which eventually marginalized 'Alī after the Prophet died. See the preceding Chapter for more discussion.

${ }^{545}$ See for instance, Ayatollah Muntazirīe, Nizām al-Hukm fïl-Islām, p. 36; and al-Sayyid al-Mar'ashī, Sharh Ihqāq al-Haqq, Vol. 15, pp. 92-113. See also Muḥammad al-Riyshahrī, Mūsū'ah al-Imām 'Alī ibn Abī Tâalib fil-Kitāb wal-Sunnah wal-Tārīkh, Vol. 2, pp. 25-8; Ibid. Vol. 2, pp. 31-7; and, in particular, Ibid. Vol. 2, pp. 196-228.

\footnotetext{
${ }^{546}$ See, for instance, Ahmad ibn Hanbal, al-Musnad, Vol. 1, p. 119; Ibid. Vol. 4, p. 370; Ibid. Vol. 5, p. 419; Ibn Kathīr, al-Bidāyah wal-Nihāyah, Vol. 9, p. 194; Abū 'Abdullāh ibn Mājah, Sunan ibn Mājah, Vol. 1, pp. 43-5; and Muhammad al-Tirmadhī, al-Sậ̄h, Vol. 5, p. 297. Numerous Shī'ah sources have reported the Hadīth as well. For the Shī'ah version of the "Sermon of Ghadīr al-Khum" see "Allāmih Majlisī, Bihar alAnwār , Vol. 37, pp. 204-217.

${ }^{547}$ For more information on the "Farewell Pilgrimage," see Muḥammad ibn Ismā‘̄il al-Bukhārī, al-Ṣahīh Vol. 5, pp. 123-5; Ibn Kathīr, al-Bidāyah wal-Nihāyah, Vol. 5, pp. 125-227; and Aḥmad ibn Abī Ya'qūb, Tārīkh Ya'qūbì, Vol. 2, pp. 109-12.

${ }^{548}$ Similar to the word Walī, Mawlā implies "bearer of Wilāyah and Walāyah." Walī is sometimes associated with Walāyah and Mawlā with Wilāyah. Such associations, however, are not clear-cut and both terms can imply either Wilāyah or Walāyah. For a mainstream Shī'i discussion of the word Mawlā in this Ḥadīth, see 'Allāmih Majlisī, Bihar al-Anwār, Vol. 37, pp. 237-253.
} 
The word Mawlā comes from the same Arabic root $w-l-y$, from which the terms Wilāyah and Walāyah are derived. Therefore, Shī'ah writers have generally interpreted the "Hadīth of Ghadīr al-Khum" as the official announcement that "Alī would be the bearer of Wilāyah and Walāyah after the Prophet. ${ }^{550}$ They have understood the term Mawlā in its more literal sense of the "ruler" or the "patron." The Shī'i interpretation rests upon several $\operatorname{Sh}^{\overline{1}}{ }^{‘} \overline{1}$ premises. First is the Shī's emphasis on the principle of Divine Justice that, according to Shī'ah Islam, has been manifested in the sacred hierarchies of Wilāyah and Walāyah. The Muslim doctrine of the "Seal of Prophecy," 551 therefore, did not mean that God would leave Muslims without a Mawlā after the prophets, Shī‘ahs argued. Such an "abandoning of mankind" would have contradicted the Divine Justice and the Divine Providence for His devotees. ${ }^{552}$ According to Shī'ahs, this is why the Prophet made such an announcement in the Valley of Khum just months before his death. It was to declare the "continuation of the Divine Grace" through Wilāyah and Walāyah in the person of 'Alī. In the Shī's version of the "Farewell Sermon," furthermore, the Prophet goes on to compare 'Alī's status to himself as identical to that of Aaron to Moses. ${ }^{553}$ The

\footnotetext{
${ }^{549}$ See 'Allāmih Amīn̄i, al-Ghadīr; 'Allāmih Majlisī, Bihar al-Anwār , Vol. 37, pp. 126-253; Aḥmad ibn Abī Ya'qūb, Tārīkh Ya'qūbì, Vol. 2, p. 112; al-Sayyid al-Mar'ashī, Sharh Ihquāq al-Haqq, Vol. 21, pp. 21-121; and Muḥammad al-Riyshahrī, Mūsū' 'ah al-Imām 'Alī ibn Ab̄ Țālib fil-Kitāb wal-Sunnah wal-Tārīkh Vol. 2, pp. 251-386. See also Muhammad al-Tirmadhī, al-Șahīh, Vol. 5, p. 297.

${ }^{550}$ See, for instance, Muhammad al-Riyshahrī, Mūsū'ah al-Imām 'Al̄̄ ibn Abì Ṭālib fil-Kitāb wal-Sunnah wal-Tārīkh Vol. 2, pp. 251-386.

${ }^{551}$ Based on the Qur'annic verses, Muslims believe that the Prophet was the last of the chain of the prophets sent by God. This belief is usually referred to as the "Seal of Prophecy" for in the verse 33:40 the Prophet is called Khātam al-Nabīyīn, or "the seal of the prophets."

${ }^{552}$ See, for instance, See Muṭahharī, Murtạ̣ā. Walā'-hā wa Wilāyat-hā. pp. 67-8.

${ }^{553}$ See 'Allāmih Majlisī, Bihar al-Anwār, Vol. 37, pp. 139-40; and Ibid. Vol. 37, p. 206. Sunnī sources have also reported such comparisons made by the Prophet, although without mentioning whether or not it
} 
comparison, according to $\mathrm{Sh}^{\mathrm{i}} \mathrm{ah}$ Muslims, is an indication that the Prophet transmitted his Wilāyah to 'Alī in the fullest extent possible in Ghadīr al-Khum. ${ }^{554}$ By doing so, the Prophet guaranteed that the world would not be devoid of a Walī after his death. Secondly, Shī'ah jurists have argued that the "fate of the Ummah" was so important to the Prophet that he could have not simply ignored the issue of his political succession during his lifetime. ${ }^{555}$ To these jurists, the Prophet did address that question in Ghadīr alKhum. ${ }^{556}$

Sunnī commentators, on the other hand, have interpreted the Hadīth of Ghadīr alKhum as yet another special praise of 'Alī by the Prophet. In fact this narration along with several other Prophetic traditions has led to the venerated status of 'Alī among Sunnī

happened during the "Farewell Pilgrimage." See, for instance, Muhammad al-Tirmadhī, al-Ṣahīh, Vol. 5, p. 304; and Abū 'Abdullāh ibn Mājah, Sunan ibn Mājah, Vol. 1, p. 45.

${ }^{554}$ One of the explicit Shī'ī accounts of 'Alī’s Wilāyah and Walāyah in Ghadīr al-Khum is reported by Shaykh al-Ṭusīi. According to Shaykh al-Ṭusī, in one of the anniversaries of the day of Ghadīr al-Khum, 'Alī ibn Abī Țālib gave a sermon. In the sermon, 'Alī articulated a Shī'ī account of the ontology of Wilāyah and Walāyah in relation to the events of Ghadīr al-Khum. He referred to a "selected group of people" after the Prophet whom God had chosen to be "the callers to the Truth and the guides to God." These people were, according to him, "God's validating proof," or Hujjat. He then asserted the Walayyah of these "selected devotees to God" by declaring that "God had made them witness to His creation [or to His people]; and has transferred His Walāyah to them on whatever of His affairs He has desired so." See Shaykh al-Ṭūsī, Mīṣāhh al-Mutahajjid, pp. 752-7.

${ }^{555}$ For various Shī'‘ articulations of these arguments, see al-Shaykh Kāshif al-Ghițā’, Așl al-Shì 'ah wa Ușülahā, Vol. pp. 221-31; al-Sayyid al-Husaynī al-Mīlānī, al-Imāmah fì Ahamm al-Kutub al-Kalāmīyyah wa 'Aqīdah al-Imāmīyyah -in particular pp. 43-56; and Shaykh Muḥammad Rị̣ā al-Muzaaffar, 'Aqā' 'id alImāmīyyah, pp. 65-76.

${ }^{556}$ It must be mentioned that an important genre of writings by prominent Shi' ${ }^{\circ}$ ah theologians deal with the question of Wilāyah and Walāyah of 'Alī ibn Abī Țālib. The genre of writings investigates the Qur'ānic and Hadīth foundations of this Shī'ī argument. This is for 'Alī's Wilāyah and Walāyah is the bedrock of the whole Shî'i ontology of Wilāyah and Walāyah. It is also the basis for their belief that the metaphysical hierarchy of Wilāyah and Walāyah is an essential feature of the "created world"; and that such hierarchy did not cease to exist after the Prophet died. The continuation of Wilāyah and Walāyah after the Prophet was for the simple reason that the world, according to Shī'ah theology, cannot continue to exist without Divine Wilāyah and Walāyah channeled through the Walī(s). Arguably the most well-known example of this genre of Shī'ì writing is the multi-volume al-Ghadīr by 'Allāmih Amīnī (d. 1970). See also al-Sayyid alMar'ashī, Sharh Ihquāq al-Haqq; and Muhammad al-Riyshahrī, Mūsū'ah al-Imām 'Alī ibn Abì Tălib filKitāb wal-Sunnah wal-Tārīkh. 
Muslims. They have understood the word Mawlā to imply "friend"; and the likening of 'Ali to the Prophet as Mawlā of every Muslim was to deflect some of the critiques against the former. ${ }^{557}$ In fact, one of the mainstream Muslim biographers of the Prophet, Ibn Hishām, reports that during the "Farewell Pilgrimage," some of the 'Alī's companions complained to the Prophet about 'Alī's strict manners. The Prophet then dismissed the complaints and praised "Ali for his "strict adherence to Islam." The incident is, therefore, taken as a further indication that the word Mawlā in the above Hadīth refers to a Prophetic command to befriend "Alī and to guard him against future criticisms. ${ }^{558}$ In addition, Sunnī writers have argued that had the Prophet meant 'Alī to be his successor, he would have announced such an important decision more clearly and in a number of occasions prior to his death. ${ }^{559}$

${ }^{557}$ See, for instance, Mīr Sayyid Sharīf Jurjānī, Sharh al-Mawāqif al-İjī, Vol. 8, pp. 359-61.

${ }^{558}$ See Ibn Hishām, Sìrah al-Nabawìyyah, Vol. 4, pp. 1021-2. Note that Ibn Hishām does not report the "Hadīth of Ghadīr al-Khum" in his version of the "Farewell Sermon," which was apparently delivered right after the abovementioned dispute between 'Alī and others.

${ }^{559}$ For a mainstream Sunnī response to Shī‘i arguments regarding the "verse of Wilāyah" and the "Hadīth of Ghadīr al-Khum" see Fakhr al-Dīn Rāzī, Tafsìr al-Kabīr, Vol. 12, pp. 25-31. Note that there is, arguably, another interpretation distinct from the mainstream Shī'i and from the mainstream Sunnī accounts of the "Ḥadīth of Ghadīr al-Khum." This belongs to Sunnī Șūfī Muslims. While Shī'ah Muslims believe that in Ghadīr al-Khum, "Alī became the bearer of the Prophetic Wīlayah, i.e. external and exoteric authority, and Walāyah, i.e. esoteric and spiritual authority, these Sunnī Șūfĩ commentators have argued that it was the latter authority, i.e. Walāyah, that was transmitted to "Alī. There is no wonder, therefore, that the majority of traditional Șūfì orders have their Silsilahs, or "spiritual genealogy," going back to the Prophet through "Alī ibn Ab̄i Țālib [see Dakake, Maria M. (2007). The Charismatic Community: Shi 'ite Identity in Early Islam. Albany: State University of New York Press. pp. 33-48]. The remaining few have Abū Bakr, the first Sunnī caliph, as their spiritual patriarch after the Prophet. A few Șūfĩ orders, e.g. the North African Shādhilī Order, have both 'Alī ibn Abī Țālib and Abū Bakr in their Silsilah. Mainstream Sunnī commentators, on the other hand, reject that the "Hadīth of Ghadīr al-Khum" implies any internal or external authority being transmitted to "Alī.

Note that the "Hadīth foundation" of Wilāyah and Walāyah in Shī'ah Islam goes beyond these two Prophetic traditions. The Shī'ah Imāms themselves produced an important body of teachings regarding Wilāyah and Walāyah. As mentioned before, two of the more important Hadīths in this regard are attributed to the eighth Imām, "Alī ibn Mūsā. These are the "Hadīth of the Golden Chain" and the "Hadìth of the Fortress of Wilāyah." See the preceding Chapter as well as Shaykh al-Șadūq, 'Uyūn Akhbār al-Ridhā, Vol. 
It must be underlined that the notions of Wilāyah and Walāyah exist in Sunnī Islam as well, and especially within the metaphysical doctrines of various Șūfĩ orders in the Sunnī world. ${ }^{560}$ The main difference between Șūfî Sunnīs and Shī'ah Muslims in this regard is that the status of the Shī'ah Imāms are less highlighted by the former group. Sunnī Șūfîs do believe that, following the death of the Prophet, there have been and will always be certain number of living saints who would carry the status of Walāyah. In fact, many Sunnī Șūfī orders incorporated the names of the Shī'ah Imāms within the ranks of their venerated saints and Shaykhs. ${ }^{561}$ In contrast, Shī'ah Muslims believe that the status of the Imāms are considerably higher than those of other Muslim saints. In fact, the mainstream Shī'`̄ belief holds that the spiritual status of the Imāms is the "highest achievable" rank after the "Seal of Prophecy." While acknowledging the significance of non-Imām Awlīyā' (or "possessors of Walāyah), Shī'ah Muslims considered them decisively inferior to the Imāms and, in fact, indebted to the Imāms' Walāyah for bestowing upon the saints their spiritual status. ${ }^{562}$ In any case, the importance of Walāyah in Tașawwuf did not translate to its significance in Sunn̄ theology for in general

1, pp. 143-5; Ibid. Vol. 1, p. 146; and 'Allāmih Majlisī, Biḥ̄ar al-Anwār, Vol. 49, pp.120-3.

${ }^{560}$ Henry Corbin believes that a common core of Tașawwuf and Shī'ah Islam is the notion of Walāyah. See Corbin, Henry. The Man of Light in Iranian Sufism. See also Muțahharī, Murtaḍā. Walā'-hā wa Wilāyat-hā. p. 85. For the discussion of Walāyah and Wilāyah in Sunnī Șūfî traditions, see Chodkiewicz, Michel. (1993). Seal of the Saints: Prophethood and Sainthood in the Doctrine of Ibn 'Arabì. Cambridge: The Islamic Text Society. See pp. 47-59 in particular. See also various works of the prominent Sunnī Șūfì, Ibn 'Arabī especially Fușūs al-Hikam and Futūhăt al-Makkīyyah, as well as the excellent summary of the notion of Walāyah by Hermann Landolt in Encyclopedia of Religion [see Eliade, Mircea. (Ed.). (1987). Encyclopedia of Religion. New York: Macmillan. Vol. 15, pp. 316-22].

${ }^{561}$ In many Sunnī Șūfĩ Silsilahs one may find the names of all or some of the first eight Shī‘ah Imāms.

${ }^{562}$ In addition, there is arguably the middle group of Shī'ah Șūfîs. Their position lies somewhere between that of mainstream Shī'ì beliefs and the position of Sunnī Șūfìs. While venerating the Imāms as supreme saints, Shī‘ah Șūfīs, in general, have paid more tribute to non-Imām saints of Sunnī or Shī‘ī origin. 
Tașawwuf has not been the mainstream interpretation of Islam in the Sunnī world. Moreover, the notion of Wilāyah and external "sacred" authority is generally less highlighted in Tașawwuf compared to Shī'ah Islam. This is yet another reason why the ontology of Wilāyah and Walāyah remains an important point of distinction between Sunnī Islam and Shī‘ah Islam.

Besides their theological implications, Wilāyah and Walāyah shaped the minority Shī‘ah Muslims’ self-perception in important ways. While Sunn̄̄ Muslims viewed themselves as the architects and the guardians of Muslim civilizations, early Shī'ah Muslims tended to see themselves as the guardians of Islam's "Sacred secrets," and above all Wilāyah and Walāyah. ${ }^{563}$ The geographical expansion of the Muslim world to North Africa, the Levant, Mediterranean Europe, South, East and Central Asia was, for the most part, due to the campaigns of the Sunnī caliphs. The Umayyad dynasty laid the material foundations for the rise of Muslim civilizations, which culminated in the "Golden Age" during the Abbasid caliphate. It was under the patronage of Sunnī Abbasid caliphs that Baghdad became one of the prominent centers of education and arts in the eighth century. Later on, it was the Sunnī Ottomans who championed the so-called "Muslim cause" in the face of rising Europe into the modern times. The fact that many early Western

\footnotetext{
${ }^{563}$ Along with 'Uthmān ibn Maẓ'ūn and Salmān al-Fārsī, 'Alī ibn Abī Ṭālib was among the disciples of the Prophet who appear to have been particularly interested in the esoteric aspects of Islam along with its exoteric teachings. In addition, "Ali appears to have been an essential figure among the disciples for his contribution to Muslim mysticism. His rather different understanding of the Prophet's life and message is evident when one compares the reported body of traditions and sayings by "Alī with that of other disciples. Some of the extremely mystical Shīî̀ prayers such as "The Sha'bānīyyah Supplication," or Munājāt, "The Prayer of Kumayl," "The Supplication of the Kūfah Mosque," and "The Prayer of the Morning," or Șabāh, belong to "Alī. See "Alī ibn Abī Țālib, Nahj al-Balāghah; and Shah-Kazemi, Reza. Justice and Remembrance. For an interesting account of the mystical -and rather obscure- disciple, 'Uthmān ibn Maẓ'ūn, see 'Alī ibn Abī Țālib, Nahj al-Balāghah, Hikmah 289. For an insightful discussion of association between the Shī'ah minority status and the "Truth" of their beliefs, see Enayat, Hamid. Modern Islamic Political Thoughts. pp. 18-21.
} 
scholars equated Islam with Sunnī Islam is an indication of how powerful the role of Sunn̄̄ Muslims had been in shaping the image of Islam in the West. Similar arguments may be put forward when it comes to the South and East Asia. The above argument about the role played by Sunnī Muslims is not to deny the important contributions of the Shī'ah communities and the Shī'ah "pious merchants",564 in the spread of Islam in these regions. To this day, however, the overwhelming majority of Muslims in the South, East, and Central Asia are Sunn̄̄. Throughout centuries, Sunn̄̄ Muslims expanded and protected the borders of the Muslim world. Brilliant empire builders, they tapped into the reservoir of scholars, architects, and artists from different parts of this multi-ethnic world including Persians, Turks, North Africans, Andalusians, Chinese, South and East Asians. They enriched the intellectual tapestry of Muslim civilization as patrons of the arts and sciences. Once again, this is not to dismiss the essential contributions of many Shī'ah scholars, scientists, Șūfīs, poets, and theologians in the rise of Muslim civilizations; nor to deny the noticeable cases of Shī'‘̄ "sub-civilizations" such as the Safavid Persia ${ }^{565}$ or the Fătimid Egypt ${ }^{566}$. The point is that, for the most part of the history and over the greater part of Muslim geography, it was the Sunnī rulers, caliphs, and sultans who functioned as the builders and protectors of Muslim civilizations.

\footnotetext{
564 F. Rajaee, personal communication, July 7, 2011. See also Nasr. Seyyed Hossein. (2003). Islam: Religion, History and Civilization. New York: HarperCollins. p. 142.

${ }^{565}$ In recent years, there has been a new scholarly interest in important civilizational achievements of the Safavid. See, for instance, Newman, Andrew J. (2006). Safavid Iran: Rebirth of a Persian Empire. New York: I.B.Tauris \& Co Ltd.

${ }^{566}$ See Feirahi, Davoud. Tārīkh Taḥawwūl Duwlat dar Islām. pp. 281-314.
} 
Meanwhile, Shī'ah Muslims assumed the position of the bearers of the "Sacred Knowledge," or the "Heart of Islam." ${ }^{567}$ Long before they rose to power in any quarter of the Muslim world, Shī'ah Muslims compensated for their social inferiority and material weakness by a firm belief in their central "metaphysical role" as a community, a chosen people. They believed that the majority of Muslims had digressed from the "Truths" of Wilāyah and Walāyah, and that they had forgotten the sacred "spiritual structure" the Prophet meant to reveal. Shī'ah Muslims took it, therefore, as their responsibility to protect the institution of Wilāyah and Walāyah manifested, they believed, in the persons of the Imāms. ${ }^{568}$ The esoteric dimension of Wilāyah-Walāyah ontology proved to be a suitable match for the socioeconomic setting of a minority community bereft of hopes for any external social progress. It is also in this context that one can understand why many prominent Shī'ah jurists have used the term Biyḍih Islām when referring to the protection of the Shī'ah community and later on in reference to Shī's states. ${ }^{569}$ The word Biyḍih, literally meaning egg, implies the essence or foundation; and for centuries, the Shī'ah

\footnotetext{
${ }^{567}$ This term is borrowed from Nasr, Seyyed Hossein. (2002). The Heart of Islam: Enduring Values for Humanity. New York: HarperCollins. See pages 63, 67, and 225-6 in particular. In this regard, Hamid Enayat writes "[e]soterism is closely intertwined with Shî' 1 theosophy, which explains the rationale of Sh'`ism as being merely the awareness and guardianship of the secret truth of Islam" [Enayat, Hamid. Modern Islamic Political Thoughts. p. 22]. Enayat also quotes Henry Corbin's characterization of Shī'ah Islam as "the sanctuary of Islamic esoterism" [Ibid.].

${ }^{568}$ See Dakake, Maria M. The Charismatic Community for an extensive discussion of esoteric Walāyah in early Shī‘ah Islam.

${ }^{569}$ This term can be found in the works of many later Shī'ah 'Ulamā. In modern times, the term was famously used in 'Allāmih Nā'īn̄’'s influential Tanbīh al-Ummah wa Tanzīh al-Millah. As indicated in Chapter II, the book was written prior to the Constitutional Revolution of 1905 in Persia and soon became the classic pro-Constitution document from a Shī'i perspective. The notion of protecting the Biyḍih Islām, i.e. "the essence or the foundation of Islam," was employed by both pro-Constitution and anti-Constitution "Ulamā in their efforts to religiously articulate and justify their positions. The extent of its use has rendered the notion of "protecting the Shī'ah community" a working "jurisdictional principle," i.e. Q⿳亠口冋'idah al-Fiqhī, in Shī'ah Islam. This "working principle" has been further reinforced by the doctrine of Taqiyyah as discussed in the preceding Chapter. See also Ayatollah Khomeini, Tahrīr al-Wasìlah, Vol. 1, pp. 485-6.
} 
'Ulamā have argued that protection of the Shī'ah community ${ }^{570}$ is "religiously mandatory," or al-Wājib, for it has been identified with "protecting the essence of Islam., 571

\section{Strategic Implications}

With regard to Shī‘n̄ strategic cultures, Wilāyah and Walāyah created a paradigm that allowed the doctrines of Shahādah and Taqīyyah to coexist, for Wilāyah and Walāyah projected the Shī'ah community as a "special community." The notion implied that the community may undertake extraordinary measures such as expediency, secrecy, and concealment during episodes of terror. Such was the case, according to Shī'ah historiographies, during the lives of most of the Shī'ah Imāms. There are, however, other times when the Shī'ah community must or may disregard prudence and political calculations for the sake of "upholding justice." Such was, according to mainstream Shī‘ $\overline{1}$ beliefs, the lesson of Husayn's martyrdom. As discussed in Chapter III, however, for the Shī'ah community to choose Shahādah over Taqìyyah, the permission of the legitimate bearer of Wilāyah and Walāyah became a necessity. As a result, Twelver Shī'ah Muslims historically chose sociopolitical prudence as their modus vivendi.

Meanwhile, the impacts of Wilāyah and Walāyah on Shī's̄ strategic cultures went beyond mere accommodation of Shahādah and Taqīyyah. The two notions have also had

\footnotetext{
${ }^{570}$ It must be mentioned that in the works of many Shī'ah 'Ulamā, the two terms "Shī'ah" and "Islām" have been used interchangeably, for the main audience of these works were the Shi' 'ahs and any such distinction deemed unnecessary.

${ }^{571}$ Note that the above perception has its root in Shī'ah Hadīths. For instance, the fifth Shī'ah Imām is reported to have said that "[t] he foundations of Islam are five: the daily prayers, the alms giving, the fasting [in Ramadan], the pilgrimage [to Mecca], and Wilāyah." He then declares that the most essential of the five

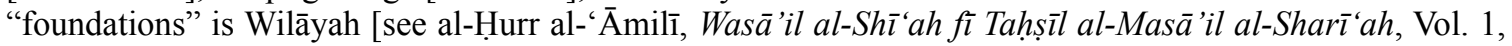
p. 7].
} 
some direct impacts upon Shī‘̄i strategic discourses and practices. Above all, Wilāyah and Walāyah served the community by strengthening the sense of internal unity. It goes without saying that for a minority strategic culture, strong bonds of unity become of significance. The more doctrinal versions of Wilāyah and Walāyah emphasized precisely such bonds of friendship and trust within the community. They also warned against developing similar bonds with people outside the community. Murtaḍa Muṭahharī, one of the chief Shī'ah thinkers of the past century, points to this particular function of Wilāyah and Walāyah in his short treatise on the subject. ${ }^{572} \mathrm{He}$ argues that, based on the Qur'ānic verses, there are two types of Wilāyah, namely "positive and negative."573 A "negative Wilāyah," which is rejected in the Qur'ān, refers to the external authority of an illegitimate and thus unjust ruler. In the verse 4:144, for instance, the believers are warned against "taking non-believers as their Walīs." 574 According to Muțahharī, the verse does not mean that "Muslims should not be kind to non-Muslims or that they should not treat non-Muslims benevolently." Instead, it means that they should not "accept the Wilāyah of non-Muslims and should not consider non-Muslims as one of themselves." ${ }^{575}$ In his formulation of Wilāyah, therefore, Muṭahharī binds the notion of

\footnotetext{
${ }^{572}$ See Muțahharī, Murtaḍā. Walā' 'hā wa Wilāyat-hā. Note that Muțahharī uses the term Wilā' Zi‘āmat, or "Wilayah of Leadership or Lordship," to refer to what is called Wilayyah in this dissertation [see Ibid. p. 66]; and he employs the term Wilā' Tașarruf, or "Wilāyah of Custodian Intervention," to refer to what is called Walāyah in this dissertation [see Ibid. p. 75].

${ }^{573}$ See Ibid. pp. 16-7.

${ }^{574}$ A similar theme can be found in the verses 60:1 and 60:2 of the Qur'ān.

${ }^{575}$ Muțahharī, Murtaḍā. Walā'-hā wa Wilāyat-hā. pp. 21-2. Muțahharī goes on to claim that "the enemies of Islam always try to transform negative Wilāyah into positive Wilāyah [and vice versa...], that is all their efforts aim at fostering intimately close relationship between Muslims and non-Muslims while creating inimical relations among Muslims themselves" [Ibid. p. 35]. This imagery is further fortified in Shī'ī popular culture through various $\mathrm{Sh}^{`}{ }^{`} \overline{\mathrm{s}}$ supererogatory prayers. In one of the commonest of these prayers, i.e.
} 
internal unity to that of strict and uncompromising boundaries between the "self" and the "other." 576 Later on, this self-other bifurcation obtained a sophisticated dynamic with the consolidation of the doctrine of Taqīyyah in the practice of Shī'ah Muslims.

On the other hand, Wilāyah and Walāyah instilled a sense of "metaphysical security" among the Shī'ah Muslims. As custodians of the "Divine Sacred Wilāyah," the Shī'ah community found a sense of purpose and a "calling" to bear with external difficulties. This particular function of Wilāyah and Walāyah aligned with that of the doctrine of Shahādah, for the latter doctrine also belittled physical pain and external suffering for the sake of a higher vocation. The "metaphysical security" was further fortified by the often quoted "Hadīth of the Fortress, or Ḥiṣn, of Wilāyah." In the Hadīth, the eighth Shī'ah Imām likened the "Wilāyah of "Alī" with a fortress guarding its inhabitants "against the Divine Wrath," ${ }^{577}$ which, needless to say, implied a sense of utmost security.

Furthermore, the discourse of Wilāyah and Walāyah socialized the Shī'ah community with a powerful sense of authority and hierarchy. Again, the hierarchical structure was of strategic significance for the survival of a persecuted community as the Shī'ahs were during the early centuries of Islam. The Imāms were revered as the persons of supreme authority at the center of the community. They were not only the external

Du'ā al-Iftitāh, Shī'ahs lament to God about "the absence of their Walī, the multitude of their enemy, the fewness of their numbers, and the severity of the calamities upon them." Here, the notion of Wilāyah and that of Wali are tied to concerns about the protection of a persecuted minority community.

${ }^{576}$ See Wendt, Alexander. Social Theory of International Politics. pp. 224-32. See also 'Alī ibn Abī Țālib, Nahj al-Balāghah, Sermon 27 for the notion of "unity based upon the Truth" and its significance according to the Shī'ah patriarch.

${ }^{577}$ See Shaykh al-Șadūq, 'Uȳ̄n Akhbār al-Ridhā, Vol. 1, p. 146. 
head of the community but also, due to their esoteric position in the "metaphysical hierarchy" of the world, the Divine Hujjat. ${ }^{578}$ The status meant that an immense power was associated with the office of the Imāms. Naturally, this exoteric and esoteric authority of the office of the Imāms created a number of challenges. The transition from one Imām to the next, for instance, became problematic from time to time, for several people claimed to be the next bearer of Wilāyah and Walāyah. As a result, a number of divisions took place in the Shī'ah community based on different chains of the bearers of Wilāyah and Walāyah. The most prominent cases of such divisions include the Kīsānīyyah who believed Muḥammad ibn Ḥanafìyyah to be the fourth Imām; the Zaydīs who followed Zayd ibn 'Alī and Muḥammad ibn 'Abdullāh instead of Ja'far ibn Muhammad; the Ismā‘̄îlīs who believed 'Ismā'īl ibn Ja'far to be the seventh Imām; and Ja'farīyyah who believed Ja'far ibn 'Alī to be the twelfth Imām. ${ }^{579}$ One after another, these groups broke away from the Twelver Imāmīyyah, who constitute the majority of the Shī‘ah Muslims today.

Besides the divisions that occurred as a result of disagreements about who the next Imām would be, the high authority of Wilāyah and Walāyah caused difficulties even within the Twelver Shī'ah community. Shī'ah sources report that the members of the community sometimes challenged the living Imām's decisions or even defied his specific commands especially during the imamate of the last Imāms. ${ }^{580}$ Some of these challengers

\footnotetext{
${ }^{578}$ See Dakake, Maria M. The Charismatic Community.

${ }^{579}$ See Modarresi Tabatabaii, Hossein. Maktab dar Farāyand Takāmul. pp. 111-67; Feirahi, Davoud. Tārīkh Tahawwūl Duwlat dar Islām. pp. 295-334; Abū al-Fatḥ Shahristānī, al-Milal wal-Nihal, Vol. 1, pp. 146189; and Ibid.Vol. 1, pp. 191-7.

${ }^{580}$ See Modarresi Tabatabaii, Hossein. Maktab dar Farāyand Takāmul. pp. 114-42. See also Abū al-Hasan
} 
were in fact prominent Shī ${ }^{`}$ ah disciples praised by the Imāms on some other occasions. ${ }^{581}$ It seems that this less than ideal relationship between the Imāms and the community was tolerated for the most part. In several Hadīths, however, the Imāms indicate that "true Shī‘ahs" are rare. ${ }^{582}$ These Hadīths might be, inter alia, an indication that the Shī'ah community did not always fully observed the implications of the doctrine of Wilāyah and Walāyah.

Towards the end of the chain of the Imāms, the internal challenges against the authority of the Imām heightened. The internal defiance culminated during the imamate of the eleventh Imām, Hasan ibn 'Alī. In fact, he is reported to have complained that more than any of his forefathers, i.e. the previous Shī'ah Imāms, he and his imamate has been doubted and defied by the Shī'ah community. ${ }^{583}$ It is with regard to these rising

ibn Bābawayh al-Qumī, al-Imāmah wal-Tabșirah, pp. 60-77; Shaykh al-Ṭūsī, Kitāb al-Ghaybah, pp. 18-70; Ibid. pp. 192-9; Ibid. pp. 218-28; Ibid. pp. 351-2; Abū Ja'far Thiqat al-Islām Kuliyn̄̄, Ușūl al-Kăfĭ, Vol. 1, pp. 320-4; Ibid. Vol. 1, p. 411; Ibid. Vol. 1, p. 511; 'Allāmih Majlisī, Bihar al-Anwārr, Vol. 26, p. 15; Ḥusayn ibn Ḥamdān al-Khașībī, al-Hidāyah al-Kubrāa, pp. 295-6; Ibid. p. 385; Shahīd al-Thānī, Haqā' 'iq al-Imān, pp. 150-1; Ibn Shahr Āshūb, Manāqib Āl Abì Tăalib, Vol. 3, p. 354; al-Qāộ̄ Nu'mān al-Maghribī, Sharh al-Akhbār, Vol. 3, p. 312; Modarresi Tabatabaii, Hossein. Maktab dar Farāyand Takāmul. pp. 51-2; and Ibid. pp. 89-90 for various intra-Shī'ah disputes, uncertainties, and disagreement as well as several examples of Shī'ahs challenging or defying the authority of their Imāms -or demanding the Imāms' explanation for their actions. For similar reports, see also Shaykh al-Șadūq, Kamāl al-Dīn wa Tamām alNi 'mah; and Shaykh al-Kashī, Rijāl al-Kashī.

${ }^{581}$ Even the Shī'ah patriarch, 'Alī ibn Abī Țālib, was not spared the occasional protests by the closest of his disciples. See Ibn Abī al-Hadīd, Sharh Nahj al-Balāghah, Vol. 3, pp. 115-116 for Mālik al-Ashtar alNakha'ì's questioning the wisdom of one of Alī's decisions or Ibid. Vol. 6, p. 78 for Muhammad ibn Abī Bakr's grievance over 'Alī's removal of him from the governorship of Egypt.

${ }^{582}$ See, for instance, 'Allāmih Majlisī, Biḥar al-Anwār, Vol. 26, pp. 1-17; Ibid. Vol. 65, p. 156; Shaykh alȘadūq, Kamāl al-Dīn wa Tamām al-Ni 'mah, p. 470; Ibid. p. 473; Abū Ja'far Thiqat al-Islām Kuliynī, Ușūl al-Käfì, Vol. 2, pp. 242-4; and Muhammad al-Riyshahrī, Mīzān al-Hikmah, Vol. 2, pp. 1545-8.

${ }^{583}$ See Modarresi Tabatabaii, Hossein. Maktab dar Farāyand Takāmul. p. 134; and Shaykh al-Ṣadūq, Kamāl al-Dīn wa Tamām al-Ni 'mah, p. 222. See also Ḥusayn ibn Ḥamdān al-Khașībī, al-Hidāyah alKubrā, pp. 325-50; Ibn Shu'bah al-Harrānī, Tuhaf al-'Uqūl, pp. 486-7; Quṭb al-Dīn al-Rāwandī, alKharā'ij wal-Jarā'ih, Vol. 1, pp- 440-50; al-Qāọī Nu'mān al-Maghribī, Sharh al-Akhbār, Vol. 3, p. 312; and Sayyid al-Khū'ī, Mu'jam Rijāl al-Hadìth, Vol. 12, p. 319. 
challenges against the authority of the Imāms that the doctrine of the "hidden -twelfthImām" ${ }^{, 54}$ becomes of strategic significance. The doctrine spared the Shī'ah community the type of bickering and internal strife that plagued other branches of Shī'ah Islam. As a result, it prevented further division and weakening of the Twelver community in the long run. ${ }^{585}$ The strategic effects of the doctrine of the "hidden Imām" becomes more evident when one considers the ill fate of the Ismā'îlī Fāttimid dynasty in North Africa, that of Nizārī Ismā'̄illīs under the leadership of Hasan al-Ṣabbāḥ ${ }^{586}$ in Persia, or that of the Zaydīs. ${ }^{587}$ These other branches of Shī'ah Islam had to deal with the destructive dynamics of transition from one Imām to the next as well as the internal challenges to the "supreme authority" of the living Imām. ${ }^{588}$ For Twelver Shī'ahs, such destructive dynamics were averted by the belief in the indirect yet supreme authority of the "hidden Imām." It

\footnotetext{
${ }^{584}$ See the following section of the Chapter for more discussion. Modarresi Tabatabaii reports a controversial statement attributed to the prominent Shī‘ah scholar, Nașīr al-Dīn Țūsī (d. 1274 C.E.), declaring 'adamahu minnā -i.e. "his [i.e. the twelfth Imām's] absence is because of us [i.e. the Shī'ahs' failing to behave towards their Imāms properly]" [see Modarresi Tabatabaii, Hossein. Maktab dar Farāyand Takāmul. p. 135]. The mainstream Shī'i belief holds that the absence of the twelfth Imām was mainly due to the mounting pressure raised against them by the Sunnī caliphate.
}

\footnotetext{
${ }^{585}$ Similar to the notions of Wilāyah, Walāyah, and Taqīyyah, the Shī's doctrine of the "hidden Imām" was articulated and established due to the endeavors of the early generations of Shi' ${ }^{\circ}$ ah theologians. The strategic significance of the theological efforts of these early Shi' ${ }^{\top}$ ah scholars becomes more notable when one considers their social and historical context. As discussed in Chapter IV, the turbulent decades after the death of the eleventh Imām are often called the age of "great bewilderment" in Shī'ah classical sources. The rising uncertainty within the community and the absence of the Imām brought the Shī'ah community to the verge of extinction. It was the writings of these early Shī'ah theologians -such as Muhammad ibn 'Abdullāh Iṣfahānī and Abū Ja'far ibn Qibih Rāzī- that eventually saved the community from being perished. See Modarresi Tabatabaii, Hossein. Maktab dar Farāyand Takāmul. pp. 183-199; and Ibid. pp. 213-38. For more discussion, see the preceding Chapter.

${ }^{586}$ d. 1124 C.E.

${ }^{587}$ See, for instance, Feirahi, Davoud. Tārīkh Tahawwūl Duwlat dar Islām. pp. 313-314; and Ibid. pp. 3314.

${ }^{588}$ For an insightful analysis of the destructive dynamics released by the high authority of Wilāyah in Shī'ah Safavid era, see Matthee, Rudi. (2012). Persia in Crisis: Safavid Decline and the Fall of Isfahan. New York: I.B.Tauris \& Co. See especially pp. 1-26.
} 
created, in other words, an authority that would be impossible to be challenged. It also

shifted the meaning of the authority of the Imām from outward Wilāyah towards inward, and more mystical, Walāyah. The doctrine of the "hidden Imām" may appear counterintuitive to non-Shī'ahs yet it has been among the central strategic doctrines that guaranteed the long-term viability of the Twelver Shī'ah community. ${ }^{589}$

\footnotetext{
${ }^{589}$ Before turning to a discussion of Shī'ah eschatology, it is worth briefly reviewing one of the modern manifestations of Wilāyah and Walāyah in Shī'ah politics. This is the theory of Wilāyat Faqīh, or "Guardianship or Supervision of Jurist," as formulated by Ayatollah Khomeini. The basic tenet of the theory has been generally accepted by prominent Shī'ah jurists throughout history. The mainstream version of the theory of Wilāyat Faqīh is as follows. The Shī'ah Imāms possess both Wilayyah, or external authority, and Walāyah, or mystical authority, to the greatest extent possible for a human being after the age of the prophets. In the absence of the Imāms, the theory maintains that Shī'ah Fuqahā are entitled to a limited scope of Wilāyah, i.e. certain aspects of the Imāms' outward authority. The limited Wilāyah of Fuqahā allows them, in the absence of the Imāms, to have the final word in certain affairs of the Shī'ah community including financial issues and judicial disputes. Most of the prominent Shī'ah Fuqahā, including Mullā Aḥmad Narāqī, Muhaqqqiq al-Karakī, Ja'far Kāshif al-Ghițā', Shaykh al-Anșārī, and 'Allāmih Nā'īnī, accept the authority of jurists in the absence of the Imāms. In two aspects Ayatollah Khomeini's articulation and implementation of the theory Wilāyat Faqīh are distinct from the mainstream version. The first distinction is the extent to which the Imāms' Wilāyah is transmitted to the jurist according to Ayatollah Khomeini's theory of Wilāyat Faqīh. The second distinction is the implicit inclusion of Walāyah in Ayatollah Khomeini's practice of Wilāyat Faqīh. In regard to the first distinction, Ayatollah Khomeini brought the theory to its logical extreme and argued that jurist's external authority was identical to that of the Imāms. He also urged the Shī'ah "Ulamā to fulfill their "religious duty" by engaging in politics and by "applying their Wilāyah." As such, Ayatollah Khomeini's articulation of Wilāyat Faqīh was a departure from the politically "quietist" tradition of most Shī'ah "Ulamā throughout history. See Ayatollah Khomeini, Hukūmah al-Islāmīyyah. See also Ayatollah Muntazirīi, Dīrāsāt fì Wilāyah al-Faqīh; Ayatollah Muntaẓirī, Nizām al-Hukm fïl-Islām; Sachedina, Abdulaziz A. (1988). The Just Ruler in Shi'ite Islam: The Comprehensive Authority of the Jurist in Imamite Jurisprudence. Oxford: Oxford University Press; and Hamid Enayat's chapter in Piscatori, James P. (Ed.). (1983). Islam in the Political Process. Cambridge: Cambridge University Press.
}

In addition to his generous expansion of jurist's Wilāyah, the way Ayatollah Khomeini implemented the theory in Iran diverged from traditional Shī'i understanding too. The official discourse of Wilāyat Faqīh in Iran implicitly incorporated the notion of Walāyah. The resulting discourse was similar to that about the status of the Safavid Shahs. These Shahs, too, claimed both Wilayyah and Walāyah. In the case of the Safavid, however, only the Shah's Wilāyah was justified through Sh``'ì discourses. The Shahs' Walāyah essentially came from Tașawwuf and the fact that the Safavid Shah was, at the same time, the head of the Șafawīyyah Șūfĩ Order. In contrast, Ayatollah Khomeini's practice of Wilāyat Faqīh was essentially Shī'ī in all its aspects. In fact, prior to the Revolution, Ayatollah Khomeini was a well-established teacher of Shī'i mysticism and Shī'ah theosophy in Qum seminary. He was an avowed admirer of Muslim mystics and theosophers such as Suhrawardī (d. 1191 C.E.), Ibn 'Arabī, and Mullā Șadrā. It is not surprising therefore that Ayatollah Khomeini's approach towards Wilāyat Faqīh had a strong mystical undertone in which the Ayatollah implicitly exerts a form of mystical and inner authority, or Walayyah. This brought his status yet closer to that of the Shī'ah Imāms as the "masters of both inner and outer worlds." Living in the neighborhood of Jamārān in Tehran, Ayatollah Khomeini used to be called by his devout followers as the Pīr-i Jamārān, i.e. Pīr of Jamārān. Pīr is the Farsi term for a Șūfì Shaykh and implies the person's spiritual 


\section{A Note on Shī'ah Eschatology}

As Christian eschatology was established around the person of Jesus, Shī'ah eschatology has been essentially developed around the person of Muhammad al-Mahdī, the twelfth Shī‘ah Imām. The similarity has sometimes led to (mis)understanding Shī‘ah eschatology in the light of Christian notions, for it is more convenient to explain Shī'ah eschatology through the familiar prism of Christianity. A genre of Western studies on the subject, therefore, have tried to identify the "Shī'ī equivalents" to Christians notions such as Armageddon and the anti-Christ. Such analogies, however, fail to understand Shī'ah eschatology within the larger edifice of Shī'ah theology. It must be emphasized that historically, Shī‘ah eschatology has not been a driving force in Shī‘ī strategic cultures. The purpose of this section is, therefore, to address some of the common misunderstandings regarding this eschatology and its interaction with strategy. ${ }^{590}$

Two particular misunderstandings need to be addressed here. The first is related to the significance of Shī'ah eschatology in the overall structure of mainstream Shī'ah theology. The second is related to the distinctly Shì'i character of this eschatology, which

authority. Both in discourse and practice, therefore, Ayatollah Khomeini's Wilāyat Faqīh was shaped by Wilāyah and Walāyah. The same jurisdictional-mystical formulation of Wilāyat Faqīh continued after Ayatollah Khomeini's death. In contrast to this mystical understanding of the theory of Wilāyat Faqīh, Ayatollah Muntazirî's articulation of the theory remained strictly legal and jurisprudential as he avoided any reference to the mystical or metaphysical authorities of the jurist in charge. See Mirtaheri, S. Amir. (November 2009). Republic of 'Urafā: The Mystical Dimension of Iranian Politics. Middle East Studies Association Annual Meeting. Boston; Feirahi, Davoud. Tārīkh Taḥawwūl Duwlat dar Islām. pp. 395-415; and Matthee, Rudi. Persia in Crisis.

\footnotetext{
${ }^{590}$ In fact, as Mesbahi argues, mainstream Shī'ah eschatology has been essentially "non-activist" and has been built around the notion of "passive waiting" for the coming of the "hidden Imām." This is why historically, "more Mahdīism has generally meant more quietism in Shī'ah Islam" [M. Mesbahi, personal communication, March 9, 2012]. This brings Shī'ah eschatology close to prudence-driven modus vivendi of Sh'`'ah Muslims based on the doctrine of Taqiyyah -at least in the discourses of the mainstream Shī'ah "Ulamā. Although some non-'Ulamā Shī'ah "activists" of modern times such as "Alī Sharī'atī tried to transform passive Shī'ah eschatology into an "activist" and "volunteerist" doctrine by dismissing the long tradition of Shī'i theological discourses on the subject.
} 
renders it a fitting module of $\operatorname{Sh}^{\top}{ }^{`} \overline{1}$ system of thought. Shī'ah eschatology, in other words, is an organic extension of the Shī's belief system based on the experience of a minority community. At the same time, its distinct Shī‘ī character means that Shī'ah eschatology cannot be properly understood unless one understands some of the foundational Shī' $\overline{1}$ concepts. Two such concepts are of particular relevance here, namely the notion of Wilāyah-Walāyah and the principle of justice. The following discussion of Shī'ah eschatology, therefore, rests upon the discussion of justice in Chapter III as well as that of Wilāyah and Walāyah in this Chapter. Before further exploring the common misunderstandings of Shī'ah eschatology, it is useful to briefly review the main premises of this eschatology.

According to Shī'ah historiographies, the last Shī‘ah Imāms and especially those who succeeded the eighth Imām ${ }^{591}$ were under mounting social and political pressure by the Abbasid caliphate. Given the antagonistic relationship between the Abbasid and the 'Alawīs (or Shī'ahs), it is reasonable to believe that these last Imāms lived under the surveillance of the authorities and that their contacts with their followers became increasingly restricted. Such a restriction considerably truncated the ability of the Imāms to effectively function as the leaders of the community. The limited direct access to the Imāms was partially compensated by the network of Shī‘ ${ }^{`}$ delegates and representatives first organized by the seventh Imām. Towards the imamate of the tenth and the eleventh Imāms, these delegates assumed a central role in administering the affairs of the community. ${ }^{592}$ The representatives were usually responsible for addressing the financial

\footnotetext{
${ }^{591}$ These include Muhammad ibn 'Al̄̄, 'Alī ibn Muhamamad, and Hasan ibn 'Alī.

${ }^{592}$ See Modarresi Tabatabaii, Hossein. Maktab dar Farāyand Takāmul.
} 
and sometimes educational needs of the community. Few of these early representatives, however, were Shī'ah scholars capable of spreading the teachings of Imāms or answering religious questions by the community. ${ }^{593}$ Most of the representatives were chosen from trusted Shī'ah elites in various places; and they were primarily responsible for the financial transactions of the community and especially for the collection of religious alms. ${ }^{594}$ The network of financial and religious representatives was to serve as a model for handling the internal affairs of the dispersed Shī'ah community in the centuries to come.

According to Shī'ah sources, the repression of the community and the restrictions imposed on the Imām heightened during the imamate of the eleventh Imām. For a long period, he was put under house watch in the city of Sāmarrā, then a military stronghold of the Abbasid caliphate. ${ }^{595}$ According to Shī'ah historiographies, his contemporary Abbasid caliphs were determined to kill any son of his so that they would solve their "Alawi problem” once and for all. The headless Shī'ah community, then, was doomed to perish. This bleak fate was averted, Shī'ahs believe, by the miraculous continuation of Wilāyah and Walāyah in the person of Muhammad al-Mahdī, the only son of Hasan ibn 'Alī who

\footnotetext{
${ }^{593}$ See Ibid. pp. 49-50.

${ }^{594}$ The alms-giving duty in Shī‘ah Islam includes Zakāt and Khums. Paying Zakāt is the common practice among both Shī'ah and Sunnī Muslims. Paying Khums, however, is a distinctly Shī'ī practice in which each Shī'ah Muslim has to pay a fifth of his overall profit at the end of the year to the Imām or his representatives. According to Modarresi Tabatabaii, the early Shī'ah Imāms did not demand their followers to pay Khums. During the imamate of the ninth Imām, however, the practice of paying Khums to the office of the Imām became a routine Sh```ī duty [see Ibid. pp. 44-5; and Shaykh al-Ṭūsī, Tahdhīb al-Ahkām, Vol. 4, p. 141]. During the age of Occultation when there is no access to the Imām, qualified Shī'ah "Ulamā collect Zakāt and Khums "on behalf of the hidden Imām."

595 See, for instance, Ibn Shahr Āshūb, Manāqib Āl Abī Ṭālib, Vol. 3, pp. 522-41. The confinement in a military center became such a determining characteristic of the eleventh Imām's imamate that brought him the epithet al-"Askarī meaning the "one who is affiliated with military."
} 
"was born under a veil of secrecy." ${ }^{596}$ Muhammad al-Mahdī’s birth is believed to have been carefully concealed from the outside world and even from the majority of the Shī ${ }^{\circ}$ ah community in order to protect the life of the young Imām. ${ }^{597}$

Upon the death of his father, however, it was no longer possible to conceal Muhammad al-Mahdī’s existence. The problem was solved in an extraordinary fashion, namely by Occultation of Muhammad al-Mahdī in 874 C.E. The Occultation continues to this day and it is believed that the "hidden Imām," or al-Imām al-Ghā'ib, continues to direct the affairs of the "chosen community" in indirect and mystical ways. The situation is believed to last until the end of days when the "return of Muhammad al-Mahdề" ushers in the final phase of man's life on earth. The "return" also brings the Shī's belief in imamate and indeed in Wilāyah and Walāyah into direct association with Shī'ah eschatology. ${ }^{598}$

\footnotetext{
${ }^{596}$ For mainstream Sh```'i accounts of Muhammad al-Mahdī, the conditions surrounding his alleged birth, and the doctrine of the "hidden Imām," see Shaykh al-Ṭūsī, Kitāb al-Ghaybah; and Shaykh al-Mufìd, Rasā'il fil-Ghaybah.
}

${ }^{597}$ As mentioned before, there existed rather widespread uncertainties within the Shi'‘ ah community at the time regarding the existence of Muhammad al-Mahdī. Later on, however, the overwhelming majority of Shī ah Muslims accepted the accuracy of the few reports of his birth and his Occultation. Shī ah Muslims also substantiated their claim by resorting to several Hadīths attributed to the Prophet and to other Shi' ${ }^{-}$ah Imāms prophesying the coming of Muhammad al-Mahdī, the circumstances of his birth, and his imamate till the end of days [see for instance Ibid.]. For more information on the early debates about the existence of Muḥammad al-Mahdī among Shī'ah Muslims, see Modarresi Tabatabaii, Hossein. Crisis and Consolidation in the Formative Period of Shi'ite Islam. The book is arguably the most informative work available in English on the early history of Shī'ah Islam.

${ }^{598}$ In Sunnī eschatology, it is believed that a descendant of the Prophet named Muhammad will appear at the end of history. Some Sunnī sources have also identified this descendant as al-Mahdī. See, for instance, Nasr, Seyyed Hossein. Islam: Religion, History and Civilization. pp. 73-4. See also Abū 'Abdullāh ibn Mājah, Sunan ibn Mājah, Vol. 2, pp. 1366-8; Ibn al-Ash'ath al-Sajistānī, Sunan Abī Dāwūd, Vol. 2, pp. 30911; Muḥammad al-Tirmadhī, al-Ṣahīh, Vol. 3, p. 344; and Modarresi Tabatabaii, Hossein. Maktab dar Farāyand Takāmul. pp. 173-4.

For more general information on Shī'ah eschatology, see Sachedina, Abdulaziz A. Islamic Messianism; Modarresi Tabatabaii, Hossein. Crisis and Consolidation in the Formative Period of Shi 'ite Islam; and chapter 2 in Nasr, S. H. et al (Eds.). Expectation of the Millennium. 
In fact, proper understanding of the Shī's doctrine of the "hidden Imām" hinges upon paying attention to the implications of the Wilāyah and Walāyah ontology in Shī'ah Islam. Similar to Șūfīs, Shī'ah Muslims believe that the earth would never be depleted of Awlīyā', or those possessing the status of Wilāyah and Walāyah and those channeling the Grace of God upon mankind. ${ }^{599}$ Therefore, the doctrine of the "hidden Imām" for Shī'ah Muslims goes beyond providing the community with a sacred, albeit unseen, patron. The "hidden Imām" is believed to be the very reason for the continuation of the Grace of God upon earth. Without him, in other words, the whole "metaphysical structure" of the universe would, it is believed, collapse. ${ }^{600}$ That is why Muhammad al-Mahdī’s eventual death after his reappearance ushers in the final chapter of the history and the beginning of the Day of Judgment, for once he is gone, there will no longer exist any channel of Wilāyah and Walāyah to hold the universe in place.

Following the "Occultation of the Imām," the already existing network of Shī'ah scholars and financial agents gradually took upon themselves to organize the community. Similar to the painful socialization that the early Christians underwent after Crucifixion, early Shī'ah Muslims slowly and reluctantly lost their hope in the immanent reappearance of Muhammad al-Mahdī. ${ }^{601}$ As indicated before, it was the later Shī'ah scholars who developed an elaborate theological structure to explain the type of relationship the

\footnotetext{
${ }^{599}$ According to some Șūfì traditions, the number of these -often unidentified-Awlīyā' at any time is fixed -usually at seven or forty. Once a Walī passes away, these Șūfĩ traditions maintain, a new one will be selected by God who receives Divine guidance in one way or another. These men are sometimes called alAbdāl and are believed to be responsible for "preserving the cosmic order" [see the entry for "Badal" by R. A. Nicholson in 1993 reprint of E. J. Brill's First Encyclopedia of Islam, Vol. IX, p. 35].

${ }^{600}$ See, for instance, Muḥammad ibn Ibrāhīm al-Nu'mānī, Kitāb al-Ghaybah, pp. 136-41.

${ }^{601}$ See Modarresi Tabatabaii, Hossein. Maktab dar Farāyand Takāmul, pp. 180-8.
} 
"hidden Imām" held with the community during Occultation. ${ }^{602}$ The latter point relates to one of the misunderstandings that one may find in Western studies of Shī ${ }^{`} a h$ eschatology, namely the place of this eschatology in the overall system of Shī'ah theology.

Even though all of the prominent Shī'ah 'Ulamā believe in the abovementioned association of Shī‘ah eschatology and the twelfth Imām, historically, the Shī‘ah religious establishment has not been comfortable with extensive or "activist" discussion of eschatological subjects. The cautious approach is arguably the result of several bitter experiences throughout the history of Shī'ah Islam when false claims of Muhammad alMahdī's reappearance rendered the community riven and bewildered. The most famous episode of such traumatic confusions happened in 1844 C.E. when Sayyid "Alī Muhammad Shīrāzī claimed to be Muhammad al-Mahdī and took the title Bāb, or the "gate." Even though Bāb was imprisoned, tried, and eventually executed in 1850 C.E., the Shī'ah religious establishment of the time could not contain the "Bābī Movement." Unlike previous messianic movements in the Shī‘ah history, the Bābī Movement broke away from Islam and eventually gave birth to the Bahā'ism, which was established by Bahā’allāh, a follower of Bāb. ${ }^{603}$ As a result of this traumatic rupture based on Shī'ah eschatology, Shī'ah 'Ulamā grew extra cautious about excessive discussion of Muhammad al-Mahdī especially by non-'Ulamā. To further justify this caution, they often quote Shī‘ah Hadīths that urges Shī‘ah Muslims to reject those who claim to know

\footnotetext{
${ }^{602}$ See, for instance, Muḥammad ibn Ibrāhīm al-Nu'mānī, Kitāb al-Ghaybah, pp. 200-8; al-Sharīf alMurtạ̣ā, al-Muqni' fill-Ghaybah, pp. 60-5; and Ibid. pp. 74-9.

${ }^{603}$ For more information on the history of Bābism and Bahā'ism from an inside perspective, see Smith, Peter. (1987). The Babi and Baha'i Religions: From Messianic Shi 'ism to a World Religion. Cambridge: Cambridge University Press. See also Chapter 24 [pp. 474-91] in Wessinger, Catherine. (Ed.). (2011). The Oxford Handbook of Millennialism. Oxford: Oxford University Press.
} 
the exact time of the reappearance of Muhammad al-Mahdī. ${ }^{604}$ In fact, a universal fear among traditional Shī'ah 'Ulamā has been the emergence of new eschatological movements that divorce themselves from the religious establishments and seek "direct contacts" with the "hidden Imām.",605 Such a course of action would mean circumvention of the religious authority of the 'Ulamā who function as the representatives of the “hidden Imām." The traditional 'Ulamā, therefore, venerate Muḥammad al-Mahdī as the "hidden leader of the community" -and indeed "that of the world"- while generally avoiding extensive eschatological discussions.

One may also find another confusion regarding Shī'ah eschatology in some of the recent discussions of the subject, which relates to the chronology of the events at the end of history according to this eschatology. Shī'ah sources do not provide a definite account of the end of history and its detailed events. Instead, the subject is often treated by reporting a number of scattered and at times conflicting reports about what will happen then. ${ }^{606}$ In particular, there is no clear equivalent to Christian "Armageddon" as an epic battle between the forces of good and evil. To be sure, Muhammad al-Mahdī has been reported to engage in series of battles following his reappearance. These battles, according to Shī'ah eschatology, would be necessary to fulfill Muhammad al-Mahdī’s

\footnotetext{
${ }^{604}$ These Hadīths can be found in various Shī'ah sources. See, for instance, Shaykh al-Ṭūsī, Kitāb alGhaybah, pp. 397-414; Ibid. pp. 425-8; and Muḥammad ibn Ibrāhīm al-Nu'mān̄̄, Kitāb al-Ghaybah, pp. 299-306.

${ }^{605}$ In popular Shī'ah culture, this approach is sometimes called mahdawīyyat bidūn rūhānīyyat -i.e. "belief in Muhammad al-Mahdī's hidden imamate without [needing] the "Ulamā." It is not difficult to understand why such an approach has faced fierce opposition by traditional religious establishment throughout the Shī'ah world.

${ }^{606}$ See, for instance, Shaykh al-Ṭūsī, Kitāb al-Ghaybah, pp. 433-66; Muhammad ibn Ibrāhīm al-Nu'mānī, Kitāb al-Ghaybah, pp. 255-355; as well as Shaykh al-Mufīd, al-Irshād, Vol. 2, pp. 368-88.
} 
mission on earth, namely to "restore justice." In fact, the saliency of the Shī's principle of justice in $\mathrm{Sh}^{-}{ }^{`}$ ah eschatology has been sometimes overlooked in the Western literature. As a result, the distinctly Shī's ${ }^{1}$ character of this eschatology in contrast to Sunn̄̄ eschatology has been missed too.

One frequently quoted eschatological statement in various Shī'ah texts, prayers, and Hadīths states that Muhammad al-Mahdī will reappear once the earth "has been filled with injustice and cruelty." In such a "desperate situation," the statement continues, Muhammad al-Mahdī will rise to "fill the same earth with justice." other Shī' ${ }^{\top} \overline{1}$ doctrines, therefore, Shī'ah eschatology has been built around the principle of justice. Once again, this is a reminder of the historical trajectory that the Shī'ah community has gone through as a persecuted minority. The promise of "restoration of justice" by Muhammad al-Mahdī offered the community a soothing hope for what lies in their future. ${ }^{608}$ To be sure, it is believed that the "restoration of justice" by Muhammad alMahdī is accompanied by the spread of "true Islam." "609 Yet, the notion of "true Islam"

\footnotetext{
${ }^{607}$ The statement, yamla'uhā qistan wa 'adlan kamā muli'ta zulman wa jawra, can be found in quite a number of Shī'ah classical sources, albeit in slightly different wordings. See, for instance, Shaykh alȘadūq, al-Tawhìd, p. 82; Shaykh al-Șadūq, Kamāl al-Dīn wa Tamām al-Ni 'mah, p. 342; Ibid. p. 369; Ibid. p. 380; Shaykh al-Tūsī, Kitāb al-Ghaybah, p. 174; Ibid. 188; Ibid. p. 464; Muḥammad ibn Ibrāhīm alNu'mānī, Kitāb al-Ghaybah, p. 69; and Ibid. pp. 83-4.
}

${ }^{608}$ In fact, available Shī‘ ${ }^{`} \mathbf{1}$ eschatological reports indicate that Muhammad al-Mahdī’s mission will be received positively by various non-Muslim people. This imagery might be relevant to the universal appeal of justice that appears as a central element in Shī'ah eschatology [see Ibid.]. On the other hand, this version of the conclusion of history is a matching end for the overall historical experience of the Shi' ${ }^{\circ}$ ahs as a community craving for eventual and absolute justice. The utopian age promised under Muhammad alMahdī offers such a perspective for the "chosen community" to finally put behind the position of being a minority. Shī'ah classical sources often refer to the verses 24:55, 28:5, 7:128 and 21:105 of the Qur'ān in establishing their arguments regarding the centrality of justice in Shī'ah eschatology.

${ }^{609}$ It has been indicated that Muhammad al-Mahdī's call to "true Islam" will appear as if he is inviting men to a "new religion" or a "new Islam," for by that time, Islam will have become "corrupted and distorted" to such an extent that no one would recognize "true Islam." See, for instance, "Allāmih Majlisī, Bihar alAnwār, Vol. 52, p. 338; and Shaykh al-Mufīd, al-Irshād, Vol. 2, p. 384. 
seems to have been overshadowed by a justice-oriented language that, as Enayat writes, projects a "link between the Return [of Muhammad al-Mahdī] and the ultimate, global sovereignty of the righteous and the oppressed."

${ }^{610}$ Enayat, Hamid. Modern Islamic Political Thought. p. 25. 


\section{CHAPTER VI}

\section{CONCLUSION}

The historical trajectory of the Shī'ah community combined with a $\operatorname{Sh}^{\top}{ }^{`} \overline{1}$ understanding of Islam created a unique perspective on questions of identity, security, and survival. As discussed in the preceding Chapters, the Shī'ah Imāms provided the community with a rich set of precedence. Their Hadīths as well as their actions indicated a combination of "idealistic principled actions," especially in the cases of "Ali and Husayn, as well as prudence and caution, especially in the cases of the Imāms who followed Husayn. Building upon this mixture and with an eye on the state of their persecuted community, the early Shī‘ah jurists developed a complex theological edifice. They combined a number of aspiring religious ideals with rational discourses of expediency and vigilance. The uneasy mixture was in part possible due to the unique Shī'ah ontology of Wilāyah and Walāyah, for this ontology projected the Shī'ah community as a "special community" who were to guard the "heart of Islam" and, therefore, the heart of the "final" message of God to humanity. Such a special status entailed a religious necessity to protect this community. At the same time, this "uniqueness" demanded special metaphors of religious ideals. While the doctrine of Taqīyyah addressed the former necessity, the doctrine of Shahādah responded to the latter need. At the same time, Taqīyyah and Shahādah constituted the theological backbone of Shī'î̀ strategic cultures and, by extension, the modern notion of national security for various $\mathrm{Sh}^{\mathrm{i}} \mathfrak{1} \mathrm{i}$ political actors.

For analytical purposes, the doctrine of Shahādah is sometimes associated with "idealism" in this dissertation while that of Taqiyyah is related to "realism." It must be 
emphasized, however, that similar to any analytical simplification, the above bifurcation is neither clear-cut nor exhaustive. The complexity of the Shī'i theological edifice simply defies any such "reductionism," as do most ancient theologies. The complexity becomes more evident when one adds the notions of Wilāyah and Walāyah to the picture. Wilāyah and Walāyah allowed the emergence of what one may call a Shī's "transcendental realism" for which Shahādah and Taqīyyah were but different manifestations. The "transcendental" discourse allowed Shī ah jurists to avoid an otherwise uncomfortable contradiction. The ostensibly "idealistic" doctrine of Shahādah appeared as "true realism," for if one adds the metaphysical dimension to one's calculation of the chains of causes and effects, one could dismiss physical pain. ${ }^{611}$ From a non-phenomenological perspective, such an assertion might be received with skepticism. From a phenomenological outlook, however, the implications of believing in the "metaphysical structure" of the world come to the center of the inquiry. To a believer's eyes, such a structure is more than a faded attachment to the "real" reality of the material world. Instead, it is understood as an integrated part of the reality or, if one closely follows the metaphysical doctrines of most religions, even the reality itself. ${ }^{612}$

According to this perspective, even the doctrine of Taqiyyah reflects the "transcendental realism," for the ontology of Wilāyah and Walāyah projects the world as

\footnotetext{
${ }^{611}$ For an articulation of this "transcendental realism," see "Alī ibn Abī Ṭālib, Nahj al-Balāghah, Letters 53. In this letter, "Alī defends an absolute adherence to pacta sunt servanda. One of his key arguments contains his warnings against negative "metaphysical consequences" of breaking a contract. See Homayounvash, M., \& Mirtaheri, S. A. (Forthcoming 2012). Honoring Contracts as a Foundation of Peace: A Shī'ah Articulation. Journal of Religion, Conflict and Peace.

${ }^{612}$ This is arguably one of the reasons why in the discourses of traditional metaphysics as well as those contemporary Traditionalists and metaphysicians the term "realism" has a quite different connotation. Various articulations of this "metaphysical realism" may be found in mainstream doctrines of different Șūfì orders.
} 
a single whole in which the material and the metaphysical are intertwined. The notion of "single whole" is also in line with the doctrine of Unity in Islam, or al-Tawhīd. Welcoming the ideal of "sacrifice for justice," or Shahādah, becomes as much a reflection of "heeding the reality" as observing the imperatives of prudence, or Taqiyyah. In the resulting paradigm, the seemingly contradictory doctrines accommodate a reality that is at once mundane and transcendental, which is yet another reason for caution in employing convenient notions such as "idealism" and "realism."

Theological discussions often have concrete and practical implications. By moving from questions of Political Theory into the realm of Strategic Studies, ${ }^{613}$ my dissertation tries to better understand such implications. It is a fundamental assumption here that Shī‘i strategic thinking has some of its roots in Shī'ah theology. This theology has been the product of complex interactions between the understanding of Islam by Shī'ah's "founding fathers" on the one hand and the Shī'ah history on the other. We have already discussed some distinct dimensions of the Shī'ī understanding of Islam in Chapter V. Therefore, it is worth briefly reviewing the overall picture of Shī'ah history here.

For analytical purposes, one can divide this history into two phases. ${ }^{614}$ First is the "formative phase" of Shī‘ah Islam during which Shī‘ah Muslims were minorities living under a non-Shī‘ah, Muslim political rule. The "formative phase" arguably stretches about nine centuries from 632 C.E., i.e. the death of the Prophet, to the rise of the Safavid

\footnotetext{
${ }^{613}$ See Chapter II.

${ }^{614}$ This division of Shī'ah history was initially developed through a series of discussions with Professor Mohsen Kadivar in September 2010.
} 
dynasty in Persia in 1501 C.E. ${ }^{615}$ The "formative phase" also witnessed the consequential death of the Prophet's grandson, Husayn, in Karbalā in 680 C.E. The foundation of most of the major themes in Shī'ah theology was laid during this phase first by the Shī'ah Imāms and then by the Shī'ah jurists. In particular, important Shī's doctrines related to security and survival were articulated in this phase and under the overwhelming influence of being a minority.

The second phase of the Shī'ah history began when Twelver Shī'ahs rose to power in a major political unit of the Muslim world, i.e. Persia. Safavid Persia has been the beginning of the most viable Shī' $\overline{1}$ political rule in Muslim history. ${ }^{616}$ The second phase itself may be divided into two periods. The first stretches from 1501 C.E. until 1979 when Shī'ah Shahs were in power. During this period, Shī'ah 'Ulamā did not have “direct" access to political power, although they often exerted indirect influence over politics. ${ }^{617}$ In 1979, however, the Shī'ah 'Ulamā became the "bearer of political Wilāyah"

\footnotetext{
${ }^{615}$ This bifurcation of the Shi'‘ ah history is not a definite one. In particular, it does not mean that during the "formative phase" there has been no Shī'i political rule. To the contrary, during these centuries, there have been important episodes in which Shī'ah Muslims rose to power for short periods of time in certain parts of the Muslim world. These significant exceptions, however, did not lead to a viable Shī'i political structure similar to what the rise of the Safavid gave birth to in Persia. Notable cases of Shî'i rise to political power in the first period of Shī'ah history include the reign of Idrīsid in Morocco ( $\left(8^{\text {th }}-10^{\text {th }}\right.$ centuries); Hamdānid in Syria $\left(9^{\text {th }}-11^{\text {th }}\right.$ centuries $)$; Fātimid in Egypt $\left(10^{\text {th }}-12^{\text {th }}\right.$ centuries $)$; Zīyārid in Persia $\left(10^{\text {th }}-11^{\text {th }}\right.$ centuries), and Būyid in Persia $\left(10^{\text {th }}-11^{\text {th }}\right.$ centuries). Some prominent scholars of Shī'ah history such as Richard Bulliet believe that the lasting legacies of these pre-Safavid Shī'i dynasties have been small compared to those of the Safavid [R. Bulliet, personal communication, March 5, 2010].

${ }^{616}$ Again, this is not to dismiss the short-lived non-Shī'ah rules that emerged in Persia in between the demise of the Safavid dynasty in 1736 C.E. and the rise of the Shī‘i Qājār dynasty in late eighteenth century.

${ }^{617}$ This separation of "religious authority" from "political authority" arguably allowed Shī‘ah "Ulamā to temporarily contain the tension in Shī'ah political theology between "idealistic" pro-justice forces on the one hand and political expediency on the other.
} 
in Iran. In both periods of the second phase, however, the Shî' 1 i theological doctrines that had been articulated in the "formative phase" survived.

During its formative centuries, Shī‘ah Islam was under considerable socioeconomic pressures. Similar to many other minority groups, therefore, justice became a central notion in Shī‘ah theology. In parallel, the physical insecurity of Shī‘ah Muslims led to the emergence of survival strategies, or Taqiyyah, and survival metaphors, e.g. Shahādah. As discussed in Chapter IV, Taqīyyah was sanctioned by Shī‘ah religious authorities and provided Shī‘ ah Muslims with a considerable flexibility aimed at survival. It allowed Shī'ah Muslims under a perceived threat of death or bodily injury to conceal their beliefs. More importantly, the practice of Taqiyyah helped Shī'ah Muslims to internalize the notion of expediency and to feel religiously comfortable in observing it. As discussed in Chapter IV, however, there have been legal and theological nuances around the notion of Taqīyyah because of its considerable potential.

The more "idealistic" doctrine of Shahādah also emerged in this formative phase. As discussed in Chapter III, Shī‘̄i Shahādah also obtained a "mystical" flavor due to its ultimately sacrificial imagery. In terms of perception of security and survival, the doctrine projected utmost physical insecurity of death as utmost metaphysical security of redemption. As a result, Shahādah may be considered as the central Shî‘i metaphor of security. In this metaphor, the insecurity of a "chosen" group of Muslims was compensated by a narrative of "metaphysical security" manifested par excellence in the story of the Prophet's grandson, Husayn, in Karbalā.

The narrative, itself, could be considered as a Constructivist articulation of human security in which the "cosmic dimension" emerges as an essential element of human 
existence in this world. Husayn became the embodiment of "moral and metaphysical victory" despite his utter physical defeat, the slaughter of his companions, and the imprisonment of his family. It was through his iconic martyrdom, the narrative maintains, that Husayn achieved the ultimate security through "immediate salvation." The resulting discourse of Shahādah held that physical and temporal pain was not comparable to the reward that lies afterwards. It became a construction of security in which death, the usual emblem of ultimate insecurity, was represented as the cradle of ultimate security. Such a social construction was further strengthened by a social reality that denied Shī'ah Muslims an outlook of material security and prosperity. Deprived of security, Shī'ah Muslims took refuge in "metaphysical security." As discussed in Chapter V, a similar notion of "metaphysical security" emerged within the ontology of Wilāyah and Walāyah. The two notions established a Shī'̄i version of "Special Providence." They articulated various channels through which the Grace of God is bestowed upon the Shī'ah community as well as the whole of humanity. The notions carried in themselves a theme of invincibility and "determinism" towards the "eventual and guaranteed salvation," for deliverance was believed to be assured for those living under Divine Wilāyah and Walāyah.

The interplay of justice, insecurity, and Shahādah also led to an often overlooked difference between the Shī's̄ paradigm of Jihād and the Sunnī one. In Shī‘ah Islam, Jihād implied fighting against "injustice." In Sunnī Islam, it often referred to wars against "infidels." The difference is yet another example of the centrality of justice in Shì'1 discourses. In terms of Shī‘̄i strategic cultures, this "justice-oriented” Jihād allowed 
Shī'ah jurists to consider intra-Muslim wars as examples of Jihād more comfortably than their Sunn̄̄ counterparts.

Even though the doctrine of Shahādah offers powerful potential for Shī'̄ī strategic cultures, its impacts should not be overstated. As Enayat argues, the doctrine has often served the symbolic and spiritual needs of the Shī'ah community throughout history. ${ }^{618}$ In contrast, Shī'̄i strategic cultures have historically been dominated by prudent "quietism." As discussed in Chapter IV, political "quietism" has been the long-term consequence of the rather nebulous doctrine of Taqīyyah, which provided Shī'ah Muslims with a flexible menu of options in dealing with security challenges. At the same time, a primary source of insecurity for Shī'ahs during the first historical phase was the Sunnī caliphate. Therefore, an antagonism emerged in early Shī'ah theology towards political power. As a result, some scholars of Shī'ah politics have focused on the "Theology of Discontent" in Shī'ah Islam. ${ }^{619}$ It is true that in Shī'ah political theology, political power has sometimes been deemed as essentially evil. It is also true that for centuries, mainstream Shī'ah theology considered any political rule as inherently inclined towards injustice unless controlled and guided by the "infallible" Shī'ah Imāms. Yet, it is incorrect to reduce the complex system of strategic thinking among Shī'ah Muslims to mere power rejection and protest. The doctrine of Taqiyyah, for instance, is a notable example of sophisticated approach taken by $\mathrm{Sh}^{-}{ }^{`}$ ah Muslims towards political power and towards the state. ${ }^{620}$

\footnotetext{
${ }^{618}$ See Enayat, Hamid. (2010). Andīshih Sīyāsī dar Islām Mu 'āṣir. Tehran: Intishārāt Khārazmī. pp. 310-5.

${ }^{619}$ See Dabashi, Hamid. The Theology of Discontent.

${ }^{620}$ The anti-political-rule theme in Shī‘ah Islam, as Enayat writes, “does not mean that Shī'ism never compromised with the powers that be. On the contrary, for the best part of their history, Shī'i theologians and jurisconsults displayed an impressive ingenuity in devising practical arrangements with the rulers to
} 
The rapid change of status for Shī'ah Muslims from a persecuted minority to a majority in power in early Safavid period was not unproblematic. In a matter of decades, the whole socio-religious scene of Persia was transformed. ${ }^{621}$ As one may expect, the anti-political-power tendencies at the heart of Shī'ah political theology created a number of challenges for the nascent Shī' ${ }^{‘} \overline{1}$ state. A genre of studies in the field of Shī'ah Studies address this tension between a political theology rooted in minority status and the political rule. ${ }^{622}$ The second period, therefore, was a dynamic one as Shī'ah's antipolitical-power and anti-state stances had to gradually embrace the emergence of Shì ${ }^{-} \overline{1}$ political powers.

Despite the above tension at the heart of Shī'ah political theology, $\operatorname{Sh}^{\top}{ }^{`} \overline{1}$ strategic cultures continued to be developed around the triangle of Shahādah, Taqīyyah, and Wilāyah-Walāyah. In particular, the practice of expediency at the core of Taqīyyah proved to be essential in shaping the complex relationship between Shī'ah 'Ulamā and the Shī'ah courts. At the same time, a more or less national notion of security began to ensure the safety and survival of their followers" [Enayat, Hamid. Modern Islamic Political Thoughts. p. 26].

${ }^{621}$ As Professor Richard Bulliet indicates, the roots of Shī ah Islam had been strong in Persia even before the rise of the Safavid to power. This was, however, an "informal" version of Shi'‘ah Islam revolving around a "popular love for the Shī'ah Imāms." In fact, the rapid success of the Safavid in turning Persia from Sunnī Islam to Shī‘ah Islam was arguably due to these pre-existing Shī‘i sympathies among other things [R. Bulliet, personal communication, March 5, 2010]. See also Feirahi, Davoud. Tārīkh Tahawwwūl Duwlat dar Islām. pp. 411-4.

${ }^{622}$ This tension became clear to me through a number of interviews with Professor Mesbahi. As Mesbahi argues, the accommodation of a Shī'i rule proved to be a long process. This was due to the deep internalization of the anti-state Shī'ah political theology and the notion of Ghașb, or usurpation [of the legitimate authority of the Imāms]. For the most part, in fact, the fundamental antagonism towards political power in the absence of the "infallible" Imāms remained intact while practical and "realistic" accommodations of Shī'i rulers were justified on the ground of expediency. In times of political crisis, the collective interest of the Shī'ah community was invoked to provide the Shī ah Shahs with the necessary support [M. Mesbahi, Lectures, Fall 2007, and M. Mesbahi, Interviews, Fall 2011]. 
emerge, first against the Sunnī Ottomans, and secondly against Christian colonial powers of Russian, British, and Portuguese origins. As discussed in Chapter II, the antiimperialist resistance also gave prominence to the Shī's doctrine of Nafy-i Sabīl. Eventually, however, the separation of political and religious authorities proved unsustainable as the political power of the 'Ulamā gradually increased. By the time of the universal Marja 'īyah of Grand Ayatollah Burūjirdī (d. 1961 C.E.), the power accumulated in the office of a Grand Marja' was a political force waiting to be tapped into. The situation eventually led to the Islamic Revolution of 1979.

The dynamics of power before and after the Revolution in Iran lie beyond the scope of this dissertation. ${ }^{623}$ Yet, the strategic culture of the new political entity that emerged after 1979 offers an interesting case of a Shī'î strategic culture. This modern strategic culture too has its roots in the same theological triangle, namely Shahādah, Taqīyyah, and Wilāyah-Walāyah. The foundational theory of the new state, or the theory of Wilāyat Faqīh, was a manifestation of the Shī's ontology of Wilāyah and Walāyah, albeit an extreme one as discussed in Chapter V. Secondly, the doctrine of Taqiyyah was manifested itself in religious articulation of raison d'état after 1979 and the extensive use

\footnotetext{
${ }^{623}$ Mesbahi argues that the rise of the Islamic Republic in Iran has been one of the important political developments since the beginning of the "age of Occultation" in Shi' 'ah Islam. The Revolution, he argues, may be considered as the beginning of modern politics in the Shī'ah world, for Ayatollah Khomeini was the first Sh'̄'ah Faqīh to articulate an essentially Hobbesian notion of state and that of national security. The significance of this development is more evident when one considers the broader crisis of modern nationstate in the Muslim world. Historically, it has not been without difficulty for Muslims to internalize the selfreferential character of modern nation-states, as well as its glorification in the modern ideology of nationalism. In addition, the institution of modern state in the Muslim world initially emerged as the legacy of colonialism. As such, it suffered from legitimacy deficiency from the beginning. The fact that modern nation-state was a substitute for the "sacred institution of caliphate" further undermined its legitimacy in the Sunnī world. Needless to say, the objection to the legitimacy of modern nation-state in the Shî' $\overline{1}$ world has been yet stronger given the Shī'i anti-power political theology. It is in this context that Ayatollah Khomeini's religious formulation of raison d'état becomes of significance [M. Mesbahi, Interviews, Fall 2011. See also Piscatori, James. Islam in a World of Nation-States].
} 
of the notion of political expediency in justifying the survival of the state. In fact, the state modernized the doctrine of Taqiyyah and even institutionalized it. ${ }^{624}$ As the state had to tame the anti-power forces in Shī'ah Islam, which has been the legacy of many past centuries, the notion of Mașlahah, or expediency, proved to be invaluable.

Finally, scholars such as Mesbahi have argued that it was the doctrine of Shahādah that emerged as the "backbone of Iran's national security during the Iran-Iraq war in the 1980s." ${ }^{625}$ The assessment is based on the acts of sacrifice that the Shí ${ }^{‘} \overline{1}$ doctrine of Shahādah could demand the community over limited periods of time. During such times of crisis, the doctrine has been particularly powerful in shaping $\operatorname{Sh}^{\mathbf{c}}{ }^{‘} \mathbf{1}$ strategic behaviors. Over the long run, however, the doctrine of Shahādah has often had a symbolic value for the community. ${ }^{626}$ Beyond the exceptional episodes of crisis, Taqīyyah has been the modus vivendi of the community. Moreover, a consensus gradually emerged among Shī'ah jurists about the necessity of permission by a legitimate "bearer of Wilāyah" to engage in non-defensive Jihād. ${ }^{627}$ This further diminished the immediate relevance of the doctrine of Shahādah beyond the times of "defensive wars." ${ }^{228}$ In any case, it can be argued that Iranian modern strategic culture has employed both Shahādah

\footnotetext{
${ }^{624}$ For instance, a government body called the "Expediency Council" was created with the responsibility of, inter alia, identifying and protecting the strategic interests of the state.

${ }^{625}$ M. Mesbahi, Interviews, Spring 2010, and Mesbahi, Mohiaddin. Free and Confined.

${ }^{626}$ According to Enayat, this has been the case until modern times partly because of the dominance of the doctrine of Taqīyyah in Shī'ī strategic thoughts. See Enayat, Hamid. Andīshih Sìyāsī dar Islām Mu 'ạșir. pp. 314-5.

${ }^{627}$ See Chapter III.

${ }^{628}$ The rising importance of the doctrine of Shahādah in certain $\operatorname{Sh}^{-} \overline{1}^{\overline{1}}$ discourses is a rather modern phenomenon. See Enayat, Hamid. Andīshih Sìyāsī dar Islām Mu'āṣir. pp. 322-34.
} 
and Taqīyyah thus far. Whether this strategic culture will be dominated by the Shī`i modus vivendi of Taqīyyah or whether it will highlight Shahādah remains to be seen. The layout of this strategic culture, nevertheless, shows how ancient theological notions of Taqīyyah, Shahādah, and Wilāyah-Walāyah could serve as theological foundations for a Shī's̄is strategic culture. 


\section{BIBLIOGRAPHY}

Abisaab, Rula Jurdi. (1994). The Ulama of Jabal 'Amil in Safavid Iran, 1501-1736: Marginality, Migration and Social Change. Iranian Studies, 27(1-4), 103-22.

Abrahamian, Ervand. (1982). Iran between Two Revolutions. Princeton: Princeton University Press.

Adamsky, Dima. (2010). The Culture of Military Innovation: The Impact of Cultural Factors on the Revolution in Military Affairs in Russia, the US, and Israel. Stanford: Stanford University Press.

Al-Fārābi, Abū Nașr (1985). On the Perfect State. USA: Oxford University Press.

Algar, Hamid. (1981). Islam and Revolution: Writings and Declarations of Imam Khomeini (1941-1980). Berkeley: Mizan Press.

Almond, G. A., Appleby, S., \& Sivan, E. (2003). Strong Religion: The Rise of Fundamentalisms Around the World. Chicago: University of Chicago Press.

Amir-Arjomand, Said. (1984). The Shadow of God and the Hidden Imam: Religion, Political Order, and Societal Change in Shi'Ite Iran from the Beginning to 1890. Chicago: University of Chicago Press.

Amir-Arjomand, Said. (1988). The Turban for the Crown: The Islamic Revolution in Iran. Oxford: Oxford University Press.

Amir-Arjomand, Said. (1988). Authority and Political Culture in Shi 'ism. Albany: State University of New York Press.

Amir-Moezzi, Mohammad A. (1994). The Divine Guide in Early Shi Ism: The Sources of Esotericism in Islam. Albany: State University of New York Press.

Anderson, Benedict. (2003). Imagined Communities. New York: Verso.

Angell, Norman. (1972). The Great Illusion: A Study of the Relation of Military Power in Nations to Their Economic and Social Advantage. New York: Arno Press.

Antoun, Richard T. (2001). Understanding Fundamentalism: Christian, Islamic, and Jewish Movements. Walnut Creek: AltaMira Press.

Appleby, Scott. (2003). Serving Two Masters? Affirming Religious Belief and Human Rights in a Pluralistic World. In J. D. Carlson and E. C. Owens (Eds.), The Sacred and the Sovereign: Religion and International Politics (pp. 170-195). Washington: Georgetown University Press.

Armstrong, Karen. (2001). The Battle for God. New York: Random House. 
Armstrong, Karen. (2002). Islam: A Short History. New York: Random House.

Asad, Talal. (1983). Anthropological Conceptions of Religion: Reflections on Geertz. Man (NS), 18(2), 237-259.

Asad, Talal. (2003). Formations of the Secular: Christianity, Islam, Modernity. Stanford: Stanford University Press.

Bataille, George. (1989). Theory of Religion. New York: Zone Books.

Bennison, Amira K. (2009). The Great Caliphs: The Golden Age of the 'Abbasid Empire. London: I.B.Tauris \& Co.

Berger, Peter. (1967). The Sacred Canopy: Elements of a Sociological Theory of Religion. New York: Anchor Books.

Berger, Peter. (Ed.). (1999). The Desecularization of the World. Washington: Ethics and Public Policy Center.

Berger, Peter. (2000). Secularism in Retreat. In J. L. Esposito \& A. Tamimi (Eds.), Islam and Secularism in the Middle East (pp. 38-51). New York: New York University Press.

Berger, Thomas U. (1996). Norms, Identity, and National Security in Germany and Japan. In P. J. Katzenstein (Ed.), The Culture of National Security: Norms and Identity in World Politics (pp. 317-356). New York: Columbia University Press.

Bireley, Robert. (1990). The Counter-Reformation Prince: Anti-Machiavellianism or Catholic Statecraft in Early Modern Europe. Chapel Hill: University of North Carolina Press.

Black, Jeremy. (2004). Rethinking Military History. New York: Routledge.

Black, Jeremy. (2012). War and the Cultural Turn. Cambridge: Polity Press.

Bosworth, Clifford Edmund. (1996). The New Islamic Dynasties. New York: Columba University Press.

Buley, Benjamin. (2008). The New American Way of War: Military Culture and the Political Utility of Force. New York: Routledge.

Bull, Hedley. (1995). The Anarchical Society: A Study of Order in World Politics. New York: Columbia University Press.

Bulliet, Richard W. (1994). Islam: The View from the Edge. New York: Columbia University Press.

Burch, Kurt. (2002). Toward a Constructivist Comparative Politics. In Daniel Green (Ed.), Constructivism and Comparative Politics (pp. 60-87). New York: M. E. Sharpe. 
Burckhardt; Titus. (1987). Mirror of the Intellect: Essays on Traditional Science \& Sacred Art. Albany: State University of New York Press.

Buzan, B., Wæver, O., \& de Wilde, J. (1998). Security: A New Framework for Analysis. Boulder: Lynne Rienner Publishers.

Calhoun, C., Juergensmeyer, M., \& VanAntwerpen, J. (Eds.). (2011). Rethinking Secularism. Oxford: Oxford University Press.

Carlson, J. D., \& Owens, E. C. (Eds.). (2003). The Sacred and the Sovereign: Religion and International Politics. Washington: Georgetown University Press.

Carr, E. H. (2001). The Twenty Years' Crisis 1919-1939: An Introduction to the Study of International Relations. New York: Palgrave Macmillan.

Casanova, José. (1994). Public Religions in the Modern World. Chicago: University of Chicago Press.

Casanova, José. (2006). Secularization Revisited: A Reply to Talal Asad. In D. Scott \& C. Hirschkind (Eds.), Powers of the Secular Modern: Talal Asad and His Interlocutors (pp. 12-30). Stanford: Stanford University Press.

Chodkiewicz, Michel. (1993). Seal of the Saints: Prophethood and Sainthood in the Doctrine of Ibn 'Arabī. Cambridge: The Islamic Text Society.

Cohen, Eliot A. (1996). A Revolution in Warfare. Foreign Affairs, 75(2), 37-54.

Connor, Walker. (1972). Nation-Building or Nation-Destroying?. World Politics, 24(3), 319-355.

Coomaraswamy, Ananda. (2007). Figures of Speech or Figures of Thought?: The Traditional View of Art. Bloomington: World Wisdom.

Cooperson, Michael. (2005). Al-Ma'mun. Oxford: Oneworld Publications.

Corbin, Henry. (1978). The Man of Light in Iranian Sufism. London: Shambhala.

Corbin, Henry. (1986). Temple and Contemplation. London: Routledge.

Cornell, Vincent J. (1998). Realm of the Saints: Power and Authority in Moroccan Sufism. Austin: University of Texas Press.

Cozette, Murielle. (2008). What Lies Ahead: Classical Realism on the Future of International Relations. International Studies Review, 10, 667-679.

Dabashi, Hamid. (2006). The Theology of Discontent: The Ideological Foundation of the Islamic Revolution in Iran. New Brunswick: Transaction Publishers. 
Dakake, Maria M. (2007). The Charismatic Community: Shi ite Identity in Early Islam. Albany: State University of New York Press.

Dawisha, Adeed. (2009). Iraq: A Political History from Independence to Occupation. Princeton: Princeton University Press.

Duffield, John S. (Autumn 1999). Political Culture and State Behavior: Why Germany Confounds Neorealism. International Organization, 53(4), 765-803.

Durkheim, Émile. (2001). The Elementary Forms of Religious Life. Oxford: Oxford University Press.

El Fadl, Khaled Abou. (2002). The Place of Tolerance in Islam. Boston: Beacon Books.

Eliade, Mircea. (Ed.). (1987). Encyclopedia of Religion. New York: Macmillan.

Elshtain, Jean. (2004). Military Intervention and Justice as Equal Regard. In R. A. Seiple \& D. R. Hoover (Eds.), Religion and Security: The New Nexus in International Relations (pp. 115-130). Lanham: Rowman \& Littlefield.

Enayat, Hamid. (1982). Modern Islamic Political Thought. Austin: University of Texas Press.

Enayat, Hamid. (2010). Andīshih Sīyāsī dar Islām Mu 'ạṣir. Tehran: Intishārāt Khārazmī.

Esposito, John L. (2000). Islam and Secularism in the Twenty-First Century. In John L. Esposito \& Azzam Tamimi (Eds.), Islam and Secularism in the Middle East (pp. 1-12). New York: New York University Press.

Faghfoory, Mohammad H. (Forthcoming April 2012). Ethic of War and Peace in Shi'ite Islam. In G. M. Reichberg \& H. Syse (Eds.), Ethics of War and Peace in World Religions. Cambridge: Cambridge University Press.

Falk, Richard A. (2001). Religion and Humane Global Governance. New York, Palgrave Macmillan.

Falk, Richard A. (2003). A Worldwide Religious Resurgence in an Era of Globalization and Apocalyptic Terrorism. In F. Petito \& P. Hatzopoulos (Eds.), Religion in International Relations: The Return from Exile (pp. 181-208). New York: Palgrave Macmillan.

Fanon, Frantz. (2004). The Wretched of the Earth. New York: Grove Press.

Farrell, Theo. (2005). The Norms of War: Cultural Beliefs and Modern Conflict. Boulder: Lynne Rienner.

Feirahi, Davoud. (2009). Qudrat, Dānish wa Mashrū ‘̄̌yat dar Islām. Tehran: Nashr Niy.

Feirahi, Davoud. (2009). Tārīkh Tahawwūl Duwlat dar Islām. Qum: Intishārāt Dānishgāh 
Mufīd.

Feng, Huiyun. (2007). Chinese Strategic Culture and Foreign Policy Decision-Making: Confucianism, Leadership and War. New York: Routledge.

Finnemore, Martha. (1996). National Interests in International Society. New York: Cornell University Press.

Fox, Jonathan, \& Sandler, Shmuel. (2004). Bringing Religion Into International Relations. New York: Palgrave Macmillan.

Frank, Richard M. (2006). Early Islamic Theology: The Mu'tazilites and al-Ash 'ari. Texts and Studies on the Development of History of Kalām. Aldershot: Ashgate Publications.

Gaddis, John L. (2004). Surprise, Security, and the American Experience. Cambridge: Harvard University Press.

Geertz, Clifford. (1973). The Interpretations of Cultures. New York, Basic Books.

Glenn, J., Howlett, D., \& Poore, S. (Eds.). (2004). Neorealism versus Strategic Culture. Burlington: Ashgate Publishing.

Gellner, Ernest. (1992). Postmodernism, Reason, and Religion. London: Routledge.

Goldziher, Ignác. (1971). Muslim Studies (Vol. II). New York: Aldine Publishing.

Goldziher, Ignác. (2006). Muslim Studies (Vol. I). Chicago: Aldine Publishing.

Gopin, Marc. (2000). Between Eden and Armageddon: The Future of World Religions, Violence, and Peacemaking. Oxford: Oxford University Press.

Gray, Colin. (1986). Nuclear Strategy and National Style. Lanham: Hamilton Press.

Gray, Colin. (1999). Strategic Culture as Context: The First Generation of Theory Strikes Back. Review of International Studies, 25, 49-69.

Guénon, René. (1989). Oriental Metaphysics. Unknown: Hanuman Books.

Guénon, René. (1995). Fundamental Symbols: The Universal Language of Sacred Science. Cambridge: Fons Vitae.

Guénon, René. (2001). The Crisis of Modern World. Hillsdale: Sophia Perennis.

Guénon, René. (2004). The Multiple States of Being. Hillsdale: Sophia Perennis.

Guénon, René. (2004). The Reign of Quantity and the Signs of the Times. Hillsdale: Sophia Perennis. 
Habermas, Jürgen. (2002). Religion and Rationality: Essays on Reason, God and Modernity. Cambridge: The MIT Press.

Habermas, Jürgen, et al. (2010). An Awareness of What is Missing: Faith and Reason in a Post-secular Age. Cambridge: Polity Press.

Hairi, Abdul Hadi. (1977). Shiism and Constitutionalism in Iran: A Study of the Role Played by the Persian Residents of Iraq in Iranian Politics. Leiden: Brill.

Hall, M., and Jackson, P. T. (Eds.). (2007). Civilizational Identity: The Production and Reproduction of "Civilizations" in International Relations. New York: Palgrave Macmillan.

Harris, Brice F. (2009). America, Technology and Strategic Culture: A Clausewitzian Assessment. New York: Routledge.

Haynes, Jeffrey. (1998). Religion in Global Politics. New York: Longman.

Haynes, Jeffrey. (2011). Religion, Politics, and International Relations: Selected Essays. New York: Routledge.

Heidegger, Martin. (2004). The Phenomenology of Religious Life. Bloomington: Indiana University Press.

Hertog, Katrien. (2010). The Complex Reality of Religious Peacebuilding: Conceptual Contributions and Critical Analysis. Plymouth: Lexington Books.

Hoover, Dennis R., and Johnston, Douglas M. (Eds.). (2012). Religion and Foreign Affairs: Essential Readings. Waco: Baylor University Press.

Huntington, Samuel P. (1996). The Clash of Civilizations and the Remaking of World Order. New York: Simon \& Schuster.

Hurd, Elizabeth S. (2004). The Political Authority of Secularism in International Relations. European Journal of International Relations, 10(2), 235-262.

Hurd, Elizabeth S. (2008). The Politics of Secularism in International Relations. Princeton: Princeton University Press.

Husserl, Edmund. (1970). The Crisis of European Sciences and Transcendental Phenomenology. Evanston: Northwestern University Press.

Jafri, Askari. (1988). Nahj al-Balāghah (Peak of Eloquence): Sermons and Letters of ImamAli Ibn Abi Talib. Karachi: Islamic Seminary Publications.

Johnson, Robert. (2012). The Afghan Way of War: How and Why They Fight. New York: Oxford University Press. 
Johnston, Alastair I. (1995). Cultural Realism: Strategic Culture and Grand Strategy in Chinese History. Princeton: Princeton University Press.

Johnston, Alastair I. (1995). Thinking about Strategic Culture. International Security, 19(4), 32-64.

Johnston, Alastair I. (1996). Cultural Realism and Strategy in Maoist China. In P. J. Katzenstein (Ed.), The Culture of National Security: Norms and Identity in World Politics (pp. 216-268). New York: Columbia University Press.

Johnston, Douglas, \& Sampson, Cynthia. (Eds.). (1994). Religion, the Missing Dimension of Statecraft. Oxford: Oxford University Press.

Jones, David R. (1990). Soviet Strategic Culture. In C. G. Jacobsen (Ed.), Strategic Power: USA/USSR (pp. 35-49). London: St. Martin's Press.

Juergensmeyer, Mark. (1993). The New Cold War?. Berkeley: University of California Press.

Juergensmeyer, Mark. (2001). The Global Rise of Religious Nationalism. In D. N. Hopkins, L. A. Lorentzen, E. Mendieta, \& D. Batstone (Eds.), Religions/Globalizations: Theories and Cases (pp. 66-83). London: Duke University Press.

Juergensmeyer, Mark. (2003). Terror in the Mind of God: The Global Rise of Religious Violence. Berkeley: University of California Press.

Kadivar, Mohsen. (2006). Qarā’at Farāmūsh Shudih: Bāzkhān̄̄ Naẓarīyih "'Ulamā Abrār" -Talaqqī Awwalīyih Islām Shī‘ì az Aṣl "Imāmat". Madrisih, 1(3), 92-102.

Kadivar, Mohsen. (2007). Sìyāsat-Nāmih Khurāsānī. Tehran: Kawīr Publications.

Kadivar, Mohesn. (2008). Haqq al-Nās: Islām wa Huqūq Bashar. Tehran: Kawīr Publications.

Kalin, Ibrahim. (2010). Knowledge in Later Islamic Philosophy: Mullā Sadrā on Existence, Intellect and Intuition. Oxford: Oxford University Press.

Kant, Immanuel. (2011). Groundwork for the Metaphysics of Morals: A -GermanEnglish Edition. Cambridge: Cambridge University Press.

Katzenstein, Peter J. (Ed.). (1996). The Culture of National Security: Norms and Identity in World Politics. New York: Columbia University Press.

Keddie, Nikki. (1966). Religion and Rebellion in Iran: The Tobacco Protest of 1891-92. London: Frank Cass. 
Keddie, Nikki. (1968). An Islamic Response to Imperialism: Political and Religious Writings of Sayyid Jamal al-Din "al-Afghani”. Berkeley: University of California Press.

Keddie, Nikki. (1972). Sayyid Jamal al-Din "al-Afghani": A Political Biography. Berkeley: University of California Press.

Keddie, Nikki. (1980). Iran: Religion, Politics and Society: Collected Essays. New York: Frank Cass.

Keddie, Nikki. (1983). Religion and Politics in Iran: Shi ism from Quietism to Revolution. New Haven: Yale University Press.

Keddie, Nikki. (1995). Iran and the Muslim World: Resistance and Revolution. New York: New York University Press.

Keddie, Nikki. (2006). Modern Iran: Roots and Results of Revolution. New Haven: Yale University Press.

Keohane, Robert O. (2002). Power and Governance in a Partially Globalized World. New York: Routledge.

Kier, Elizabeth. (1997). Imagining War: French and British Military Doctrine between the Wars. Princeton: Princeton University Press.

Kierkegaard, Søren. (1962). Afsluttende Uvidenskabelig Efterskrift. København: Gyldendal.

Kinsely, David R. (1993). Hinduism: A Cultural Perspective. Englewood Cliffs: Prentice Hall

Kratochwil, Friedrich V. (1989). Rules, Norms, and Decisions: On the Conditions of Practical and Legal Reasoning in International Relations and Domestic Affairs. New York: Cambridge University Press.

Krause, Keith R. (1999). Culture and Security: Multilateralism, Arms Control and Security Building. New York: Frank Cass Publisher.

Kubálková, Vendulka. (2000). Towards an International Political Theology. Millennium Journal of International Studies, 29, 675-704.

Kubálková, Vendulka. (2003). Toward an International Political Theology. In F. Petito \& P. Hatzopoulos (Eds.), Religion in International Relations: The Return from Exile (pp. 79-105). New York: Palgrave Macmillan.

Lakhani, M. Ali. (Ed.). (2006). The Sacred Foundations of Justice in Islam: The Teachings of 'Ali ibn Abi Talib. Bloomington: World Wisdom. 
Lambton, Ann K. S. (1980). Theory and Practice in Medieval Persian Government. London: Variorum Reprints.

Lambton, Ann K.S. (1981). State and Government in Medieval Islam: An Introduction to the Study of Political Theory. Oxford: Oxford University Press.

Laustsen, Carsten B., \& Wæver, Ole. (2000). In Defence of Religion: Sacred Referent Objects for Securitization, Millennium - Journal of International Studies, 29, 705-739.

Lewis, Bernard. (1990). The Roots of Muslim Rage. The Atlantic Monthly, 266(3), 4758.

Lewis, Bernard. (2004). The Crisis of Islam: Holy War and Unholy Terror. New York: Random House

Liddell-Hart, Basil H. (1991). Strategy. New York: Penguin Books.

Lings, Martin. (1993). What is Sufism. Cambridge: The Islamic Text Society.

Lings, Martin. (2006). Muhammd: His Life Based on the Earliest Sources. London: Inner Tradition.

Lings, Martin. (2006). Symbol \& Archetype: A Study of the Meaning of Existence. Cambridge: Fons Vitae.

Lobell, S. E., Ripsman, N. M., \& Taliaferro, J. W. (Eds.). (2009). Neoclassical Realism, the State, and Foreign Policy. Cambridge: Cambridge University Press.

Madelung, Wilferd. (1985). Religious Schools and Sects in Medieval Islam. London: Variorum Reprints.

Madelung, Wilferd. (1988). Religious Trends in Early Islamic Iran. Albany: State University of New York Press.

Madelung, Wilferd. (1992). Religious and Ethnic Movements in Medieval Islam. Hampshire: Variorum.

Madelung, Wilferd. (1997). The Succession to Muhammad: A Study of the Early Caliphate. Cambridge: Cambridge University Press.

Mahnken, Thomas. (2008). Technology and the American Way of War Since 1945. New York: Columbia University Press.

Malekpour, Jamshid. (2004). The Islamic Drama. Portland: Frank Cass Publishers.

Martin, R. C., Woodward, M. R., \& Atmaja, D. S. (1997). Defenders of Reason in Islam: Mu 'tazilism from Medieval School to Modern Symbol. Oxford: Oneworld Publications. 
Matthee, Rudi. (2012). Persia in Crisis: Safavid Decline and the Fall of Isfahan. New York: I.B.Tauris \& Co.

Mead, Walter R. (2002). Special Providence: American Foreign Policy and How It Changed the World. New York: Routledge.

Mearsheimer, John J. (1983). Conventional Deterrence. Ithaca: Cornell University Press.

Mendieta, Eduardo. (Ed.). (2005). The Frankfurt School on Religion: Key Writings by the Major Thinkers. New York: Routledge.

Mesbahi, Mohiaddin. (Spring 2011). Free and Confined: Iran and the International System. Iranian Review of Foreign Affairs. 2(5), 9-34.

Meyer, Christoph O. (2006). The Quest for a European Strategic Culture: Changing Norms on Security and Defence in the European Union. New York: Palgrave Macmillan.

Modarresi Tabatabaii, Hossein. (1993). Crisis and Consolidation in the Formative Period of Shi 'ite Islam: Abu Ja'far Ibn Qiba Al-Razi and His Contribution to Imamite Shi 'ite Thought. Princeton: Princeton University Press.

Modarresi Tabatabaii, Hossein. (2007). Maktab dar Farāyand Takāmul: Naẓarī bar Tațawwur Mabānī Fikrī Tashayyu' dar Sih Qarn Nukhustīn. Trans. Hashem Izadpanah. Tehran: Intishārāt Kawīr.

Morgan, Forrest E. (2003). Compellence and Strategic Culture of Imperial Japan: Implications for Coercive Diplomacy in Twenty-First Century. Westport: Praeger Publishers.

Morgenthau, Hans J. (1946). Scientific Man vs Power Politics. Chicago: University of Chicago Press.

Mottahedeh, Roy. (2000). The Mantle of The Prophet: Religion and Politics in Iran. Oxford: Oneworld Publications.

Mufti, Malik. (2009). Daring and Caution in Turkish Strategic Culture: Republic at Sea. New York: Palgrave Macmillan.

Murtaẓawī, S. Ḍia’. (1998). 'Āshūra dar Fiqh. Qum: Intishārāt Daftar Tablīghāt.

Muṭahharī, Murtạ̣ā. (1989). Jādhibih wa Dāfi 'ih 'Alī. Tehran: Șadrā Publications.

Muṭahharī, Murtaḍā, (1998). Jihād. Tehran: Șadrā Publications.

Muṭahharī, Murtaḍā, (2009). 'Adl Ilāhī. Tehran: Șadrā Publications.

Muțahharī, Murtạ̣ā. (2010). Walā'-hā wa Wilāyat-hā. Tehran: Șadrā Publications. 
Nasr, S. H., Dabashi, H., \& Nasr, S. V. R. (Eds.). (1989). Expectation of the Millennium: Shi ism in History. Albany: State University of New York Press.

Nasr, Seyyed Hossein. (1972). Sufi Essays. Albany: State University of New York Press.

Nasr, Seyyed Hossein. (Fall 1982). The Spiritual Significance of jihãd. Parabola, 7(4), 14-19.

Nasr, Seyyed Hossein. (1985). Ideals and Realities of Islam. London: George Allen \& Unwin.

Nasr, Seyyed Hossein. (1989). Knowledge and The Sacred. Albany: State University of New York Press.

Nasr, Seyyed Hossein. (1993). An Introduction to Islamic Cosmological Doctrines. Albany: State University of New York Press.

Nasr, Seyyed Hossein. (1996). Religion and the Order of Nature. Oxford: Oxford University Press.

Nasr, Seyyed Hossein. (1997). Man and Nature: The Spiritual Crisis in Modern Man. Chicago: Kazi Publications.

Nasr, Seyyed Hossein. (2002). The Heart of Islam: Enduring Values for Humanity. New York: HarperCollins.

Nasr. Seyyed Hossein. (2003). Islam: Religion, History and Civilization. New York: HarperCollins.

Nasr, Seyyed Hossein. (2007). The Essential Seyyed Hossein Nasr. Bloomington: World Wisdom.

Nasr, Vali. (2006). Shi'a Revival: How Conflicts within Islam Will Shape the Future. New York: WW Norton \& Co.

Newman, Andrew J. (2006). Safavid Iran: Rebirth of a Persian Empire. New York: I.B.Tauris \& Co Ltd.

Niebuhr, Reinhold. (1932). Moral Man and Immoral Society: A Study in Ethics and Politics. New York: Charles Scribner's.

Norris, Pippa, \& Inglehart, Ronald. (2004). Sacred and Secular: Religion and Politics Worldwide. Cambridge: Cambridge University Press.

Onuf, Nicholas. (1989). World of Our Making: Rules and Rule in Social Theory and International Relations. Columbia: University of South Carolina Press. 
Onuf, Nicholas. (1998). Constructivism: A User's Manual. In V. Kubálková, N. Onuf, \& P. Kowert (Eds.), International Relations in a Constructed World (pp. 58-78). Armonk: M.E. Sharpe.

Piscatori, James P. (Ed.). (1983). Islam in the Political Process. Cambridge: Cambridge University Press.

Piscatori, James P. (1986). Islam in a World of Nation-States. Cambridge: Cambridge University Press.

Raines John. (Ed.). (2002). Marx on Religion. Philadelphia: Temple University Press.

Rajaee, Farhang. (Ed.). (1993). The Iran-Iraq War: The Politics of Aggression. Gainesville: University Press of Florida.

Rose, Gideon. (1998). Neoclassical Realism and Theories of Foreign Policy. World Politics, 51(1), 144-172.

Rosecrance, Richard. (1986). The Rise of The Trading States: Commerce and Conquest in the Modern World. New York: Basic Books.

Rosenthal, Erwin. (1962). Political Thought in Medieval Islam: An Introductory Outline. Cambridge: Cambridge University Press.

Roskin, Michael. (1999). From Pearl Harbor to Vietnam: Shifting Generational Paradigms and Foreign Policy. In G. J. Ikenberry (Ed.), American Foreign Policy: Theoretical Essays (pp. 315-336). New York: Longman.

Ruggie, John G. (1998). Constructing the World Polity: Essays on International Institutionalization. New York: Routledge.

Rustom, Muhammed. (Forthcoming 2012). The Triumph of Mercy: Philosophy and Scripture in Mullā Sadrā. Albany: State University of New York Press.

Sachedina, Abdulaziz A. (1981). Islamic Messianism: The Idea of the Mahdi in Twelver Shi 'ism. Albany: State University of New York Press.

Sachedina, Abdulaziz A. (1988). The Just Ruler in Shi ite Islam: The Comprehensive Authority of the Jurist in Imamite Jurisprudence. Oxford: Oxford University Press.

Șafarī, Ni'matullāh. (2003). Naqsh Taqīyyah dar Istinbāṭ. Qum: Būstān Kitāb Qum.

Sagan, Scott D., \& Waltz, Kenneth N. (2002). The Spread of Nuclear Weapon: A Debate Renewed. New York: WW Norton \& Co.

Said, Edward. (1978). Orientalism. New York: Vintage Books.

Șāliḥ̄ Najafābādī, Ni‘matullāh. (1970). Shahīd Jāwīd. Tehran: Unknown. 
Șāliḥ̄i Najafābādī, Ni‘matullāh. (2008). Jihād dar Islām. Tehran: Nashr Niy.

Seiple, Robert A., \& Hoover, Dennis R. (Eds.). (2004). Religion and Security: The New Nexus in International Relations. Lanham: Rowman \& Littlefield.

Schimmel, Annemarie. (1992). Islam: An Introduction. Albany: State University of New York Press

Schmitt, Carl. (1986). Political Theology: Four Chapters on The Concept of Sovereignty. Cambridge: MIT Press.

Schmitt, Carl. (1996). The Concept of the Political. Chicago: University of Chicago Press.

Schuon, Frithjof. (1982). Esoterism As Principle and As Way. Hillsdale: Sophia Perennis.

Schuon, Frithjof. (1984). The Transcendent Unity of Religions. Wheaton: Quest Books.

Schuon, Frithjof. (2003). Form and Substance in Religions. Bloomington: World Wisdom.

Schuon, Frithjof. (2003). Stations of Wisdom. Bloomington: World Wisdom.

Schuon, Frithjof. (2003). The Eyes of the Heart: Metaphysics, Cosmology, Spiritual Life. Bloomington: World Wisdom.

Schuon, Frithjof. (2003). To Have a Centre. Bloomington: World Wisdom.

Schuon, Frithjof. (2006). Sufism: Veil and Quintessence. Bloomington: World Wisdom.

Shah, T. S., Stepan, A., \& Toft, M. D. (Eds.). (2012). Rethinking Religion and World Affairs. Oxford: Oxford University Press.

Shahīdī, Sayyid Ja'far. (1995). Zindigān̄ì 'Alī ibn al-Husayn. Tehran: Daftar Nashr Farhang Islāmī.

Shah-Kazemi, Reza. (2006). A Sacred Conception of Justice: Imam 'Ali's Letter to Malik al-Ashtar. In M. A. Lakhani (Ed.), The Sacred Foundations of Justice in Islam: The Teachings of 'Ali ibn Abi Talib (pp. 61-108). Bloomington: World Wisdom.

Shah-Kazemi, Reza. (2006). Justice and Remembrance: Introducing the Spirituality of Imam 'Alī. New York: I.B.Tauris \& Co. Ltd.

Shah-Kazemi, Reza. (Summer 2009). Recollecting the Spirit of Jihad. Sophia Perennis, $1(3), 23-51$.

Shah-Kazemi, Reza. (2011). Spiritual Quest: Reflections on Qur'anic Prayer According to the Teaching of Imam 'Ali. New York: I.B.Tauris \& Co. Ltd. 
Sharī'tī, 'Alī. (2008). Islām Shināsī. Tehran: Ilhām.

Sharī'tī, ‘Alī. (2011). Husayn Wārith Ādam. Tehran: Qalam.

Sharī'tī, 'Alī. (2011). Tashayyu' 'Alawī, Tashayyu' Safawī. Tehran: Sipīdih Bāwarān.

Smart, Ninian. (1996). Dimensions of the Sacred: An Anatomy of the World's Beliefs. London: Fontana Press.

Smith, Huston. (1992). Forgotten Truth: The Common Vision of The World's Religions. New York: HarperCollins.

Smith, Huston. (2001). Why Religion Matters: The Fate of the Human Spirit in an Age of Disbelief. New York: HarperCollins.

Snyder, Jack L. (1977). The Soviet Strategic Culture: Implications for Nuclear Options, $R-2154-A F$. Santa Monica: Rand Corporation.

Snyder, Jack L. (Ed.). (2011). Religion and International Relations Theory. New York: Columbia University Press.

Sondhaus, Lawrence (2006). Strategic Culture and Ways of War. New York: Routledge.

Steiner, Barry H. (1991). Bernard Brodie and the Foundations of American Nuclear Strategy. Lawrence: University of Kansas Press.

Sterling-Folker, Jennifer. (Spring 2002). Realism and the Constructivist Challenge: Rejecting, Reconstructing, or Rereading. International Studies Review, 4(1), 73-97.

Stern, Jessica. (2003). Terror in the Name of God: Why Religious Militants Kill. New York: Harper Collins Publishers.

Subhāān̄, Ja'far. (2001). Doctrines of Shi ‘i Islam: A Compendium of Imami Beliefs and Practices. London: I. B. Tauris.

Țabāṭabā'̄̄, Sayyid Muḥammad Ḥusayn. (1975). Shi 'ite Islam. Trans. S. H. Nasr. Albany: State University of New York Press.

Ṭabāțabā'̄', Sayyid Muḥammad Husayn. (2003). Kernel of the Kernel. Trans. M. H. Faghfoory. Albany: State University of New York Press.

Taylor, Charles. (2007). A Secular Age. Harvard: Harvard University Press.

Taylor, Charles. (2012). The Meaning of Secularism. In D. R. Hoover and D. M. Johnston (Eds.), Religion and Foreign Affairs: Essential Readings (pp. 11-20). Waco: Baylor University Press.

Thomas, Scott M. (2000). Religion and International Conflict. In K. R. Dark (Ed.), 
Religion and International Relations (pp. 1-23). New York: Palgrave Macmillan.

Thomas, Scott M. (2000). Taking Religious and Cultural Pluralism Seriously: The Global Resurgence of Religion and the Transformation of International Society. Millennium, 29(3), 815-841.

Thomas, Scott M. (2005). The Global Resurgence of Religion and the Transformation of International Relations: The Struggle for the Soul of the Twenty-First Century. New York: Palgrave Macmillan.

Toje, Asle. (2008). America, the EU and Strategic Culture: Renegotiating the Transatlantic Bargain. New York: Routledge.

Vasquez, John A. (1998). The Power of Power Politics: From Classical Realism to Neotraditionalism. Cambridge: Cambridge University Press.

Wallerstein, Immanuel. (2005). Render Unto Caesar?: The Dilemmas of a Multicultural World. Sociology of Religion, 66(2), 121-133.

Walzer, Michael. (2006). Just and Unjust Wars:A Moral Argument With Historical Illustrations. New York: Basic Books.

Watt, W. Montgomery. (1961). Muhammad: Prophet and Statesman. Oxford: Oxford University Press.

Watt, W. Montgomery. (1981). Muhammad at Medina. Oxford: Oxford University Press.

Weber, Max. (1993). The Sociology of Religion. Boston: Beacon Press.

Weber. Max. (2002). The Protestant Ethics and the "Spirit" of Capitalism and Other Writings. New York: Penguin Books.

Wendt, Alexander. (1999). Social Theory of International Politics. New York: Cambridge University Press.

Wessinger, Catherine. (Ed.). (2011). The Oxford Handbook of Millennialism. Oxford: Oxford University Press.

Williams, Michael C. (2007). Culture and Security: Symbolic Power and the Politics of International Security. New York: Routledge.

Zhang, Shu Guang. (1992). Deterrence and Strategic Culture: Chinese-American Confrontations, 1949-1958. New York: Cornell University Press.

\section{Classical Sources (in Arabic)}

'Abd al-Raḥmān ibn Abī Bakr al-Suyūṭī. (Unknown). al-Durr al-Manthūr fill-Tafsīr bilMa thūrr. Beirut: Dār al-Ma'rifah lil- Țibā'ah. 
'Alā al-Dīn 'Alī al-Hindī. (1989). Kanz al-'Ummāl fì Sunan al-Aqwāl wal-Af'āl. Beirut: Mu’assisah al-Risālah.

‘Alī ibn Abī-Ṭālib. (1988). Nahj al-Balāghah. Karachi: Islamic Seminary Publications.

'Allāmih Amīnī. (1977). al-Ghadīr. Beirut: Dār al-Kitāb al-'Arabī.

'Allāmih Hillī. (1993). Tadhkirah al-Fuqahā'. Qum: Mu'assisah Āl al-Bayt li Ihyā' alTurāth.

'Allāmih Hịillī. (Unknown). Tadhkirah al-Fuqahā'. Tehran: Maktabah al-Murtaḍawīyyah li-Iḥyā’ al-Āthār al-Ja 'farīyyah.

'Allāmih Majlisī. (1983). Biḥar al-Anwār. Beirut: Mu’assisah al-Wafā'.

'Allāmih Țabāṭabā'̄̄. (Unknown). al-Mīzān fì Tafsīr al-Qur'ān. Qum: Manshūrāt Jamā'ah al-Mudarrisīn.

Abū 'Abdullāh ibn Mājah. (Unknown). Sunan ibn Mājah. Unknown: Dār al-Fikr lilȚibā'ah.

Abū al-Fatḥ Shahristān̄̄. (Unknown). al-Milal wal-Niḥal. Beirut: Dār al-Ma'rifah lilTibā'ah.

Abū al-Ḥasan ibn Bābawayh al-Qumī. (1984). al-Imāmah wal-Tabșirah. Qum: Madrasah al-Imām al-Mahdī.

Abū al-Ḥasan Mas'ūdī. (Unknown). Murawwij al-Dhahab wa Ma'ādin al-Jawhar. Unknown: Dār al-Andulus.

Abū al-Majd al-Halabī. (1994). Ishārat al-Sabaq. Qum: Mu'assisah al-Nashr al-Islāmī alTābi'ah li Jamā'ah al-Mudarrisīn.

Abū al-Qāsim al-Khū'̄i. (1990). Kitāb al-Ṭahārah. Qum: Dār al-Hādī lil-Maṭbū'āt.

Abū al-Qāsim Zamakhsharī. (1966). al-Kashshāf 'an Haqā'iq al-Tanzīl wa 'Uyūn alAqūwīl fi Wujūh al-Ta'wīl. Egypt: Maṭba'ah Muștafā al-Bābī.

Abū Ja'far Thiqat al-Islām Kuliynī. (1984/5). Ușūl al-Kāfì. Tehran: Dār al-Kutub alIslāmīyyah.

Abū Muḥammad ibn Qatibah al-Daynūrī. (1992/3). al-Imāmah wal-Sīyāsah. Qum: Intishārāt Sharīf al-Raḍ̄i

Abū Șalāḥ al-Halabī. (Unknown). al-Kāfì fìl-Fiqh. Isfahan: Maktabah al-Imām Amīr alMu'minīn 'Alī al-'Āmmah.

Aḥmad ibn A'tham al-Kūfī. (1990/1). Kitāb al-Futūḥ. Beirut: Dār al-Aḍ̂ā’' 
Aḥmad ibn Abī Ya'qūb. (Unknown). Tārīkh Ya 'qūbì. Beirut: Dār Șādir.

Aḥmad ibn Hanbal. (Unknown). al-Musnad. Beirut: Dār Șādir.

Aḥmad ibn Idrīs Hillī. (1989/90). al-Sarā'ir al-Hāwwì li-Tahrī̄r al-Fatāwī. Qum: Mu’assisah al-Nashr al-Islāmī al-Tābi'ah li Jamā'ah al-Mudarrisīn.

al-Hurr al-'Āmilī. (1983). Wasā'il al-Shī‘ah fì Taḥșil al-Masā'il al-Sharī'ah. Beirut: Dār Ihyā' al-Turāth al-'Arab̄i.

al-Hurr al-'Āmilī. (1997/8). al-Fușūl al-Muhimmah fî Uṣūl al-A'immah. Qum: Mu’assisah Ma‘ārif Islāmī Imām Rị̣ā.

al-Mīrzā Jawād al-Tabrīzī. (1995). Șirāt al-Nijāt fì Ajwibah al-Istiftā'āt. Qum: Daftar Nashr Barguzīdih.

al-Qāḍī Nu'mān al-Maghribī. (1993/4). Sharh al-Akhbār. Qum: Mu'assisah al-Nashr alIslāmī al-Tābi'ah li Jamā'ah al-Mudarrisīn.

al-Qundūzi al-Hanafì. (1995/6). Yanābi ‘ al-Mawaddah li-dhawī al-Qurbā. Qum: Dār alUswah lil-Ṭibā'ah.

al-Sayyid al-Husaynī al-Mīlānī. (1993). al-Imāmah fì Ahamm al-Kutub al-Kalāmīyyah wa 'Aqīdah al-Imāmīyyah. Qum: Intishārāt Sharīf al-Raḍ̄i

al-Sayyid al-Khānsārī. (1985). Jāmi ‘ al-Madārik. Tehran: Maktabah al-Șadūq.

al-Sayyid al-Mar'ashī. (Unknown). Sharh Ihquāq al-Haqq. Qum: Maktabah Āyatullāh alMar'ashī al-Najafī.

al-Sharīf al-Murtaḍā. (1989). Tanzīh al-Anbīyā’’. Beirut: Dār al-Aḍ̂ā'.

al-Sharīf al-Murtaḍā. (1995). al-Muqni' fìl-Ghaybah. Beirut: Mu'assisah Āl al-Bayt li Ihỵā' al-Turāth.

al-Shaykh Kāshif al-Ghițā'. (1994/5). Aṣl al-Shī'ah wa Ușūlahā. Qum: Mu'assisah alImām ‘Alī.

Amīn al-Islām Ṭabarsī. (1966). Kitāb al-Iḥtijāj. Najaf: Dār al-Nu'mān lil-Ṭibā'ah.

Amīn al-Islām Tabarsī. (1995). Majma 'al-Bayān. Beirut: Mu'assisah al-A'lamī lilMaṭbū'āt.

Ayatollah Khomeini. (1970/1). Taḥrīr al-Wasīlah. Najaf: Dār al-Kutub al-'Ilmīyyah.

Ayatollah Khomeini. (1979). Hukūmah al-Islāmīyyah. Beirut: al-Mu'assisah al'Arabīyyah. 
Ayatollah Muntazirīi. (1988). Dīrāsāt fì Wilāyah al-Faqīh wal-Fiqh al-Dawlah alIslāmīyyah. Qum: al-Markaz al-‘'Alamī lil-Dirāsāt al-Islāmīyyah.

Ayatollah Muntazirīi. (2001/2). Niẓām al-Hukm fìl-Islām. Qum: Hāshimiyūn.

Fāḍil Hindī. (1995/6). Kashf al-Lithām 'an Qawāid al-Aḥkām. Qum: Mu'assisah alNashr al-Islāmī al-Tābi'ah li Jamā'ah al-Mudarrisīn.

Fakhr al-Dīn Rāzī. (1978/9). Tafsīr al-Kabīr. Egypt: Unknown.

Ḥasan ibn Mūsā Nawbakhtī \& Sa'd ibn 'Abdullāh al-Qummi. (1992). Firaq al-Shì'ah. Cairo: Dār al-Rashād.

Hasan ibn Sulaymān al-Ḥillī. (1950). Mukhtașar Baṣā'ir al-Darajāt. Najaf: al-Maṭba'ah al-Haydarīyyah.

Ḥusayn ibn Ḥamdān al-Khașībī. (1991). al-Hidāyah al-Kubrā. Beirut: Mu'assisah alBalāgh lil-Ṭibā'ah.

Ibn Abī al-Hadīd. (Unknown). Sharh Nahj al-Balāghah. Qum: Mu’assisah Ismā'īlīyān lil-Ṭibā'ah.

Ibn al-Ash'ath al-Sajistānī. (1990). Sunan Abī Dāwūd. Unknown: Dār al-Fikr lil-Ṭibā'ah. Ibn al-Athīr. (1966). al-Kāmil fīl-Tārīkh. Beirut: Dār Șādir/Dār Beirut.

Ibn Hishām. (1963). Sīrah al-Nabawīyyah. Cairo: Maktabah Muḥammad 'Alī Șabīḥ \& Sons.

Ibn Kathīr. (1988). al-Bidāyah wal-Nihāyah. Beirut: Dār Iḥyā’ al-Turāth al-‘Arabī.

Ibn Kathīr. (1992). Tafsīr al-Qur'ān al- 'Az̄ìm. Beirut: Dār al-Ma'rifah lil-Ṭibā'ah.

Ibn Shahr Āshūb. (1956). Manāqib Āl Abī Țālib. Najaf: al-Maktabah al-Haydarīyyah.

Ibn Shu'bah al-Harrānī. (1984). Tuhaf al- 'Uqūl. Qum: Mu'assisah al-Nashr al-Islāmī alTābi'ah li Jamā'ah al-Mudarrisīn.

Imām al-Shāfi‘’̄. (1983). Kitāb al-Umm. Unknown: Dār al-Fikr lil-Ṭibā‘ah.

Mīr Sayyid Sharīf Jurjān̄̄. (1907). Sharh al-Mawāqif. Egypt: Maṭba'ah al-Sa‘ādah.

Muhạmmad al-Riyshahrī. (1995/6). Mìzān al-Hikmah. Unknown: Dār al-Hadīth lilȚibā'ah.

Muhammad al-Riyshahrī. (2000). al-'Aql wal-Jahl fìl-Kitāb wal-Sunnah. Beirut: Dār alHadīth lil-Ṭibā‘ah. 
Muhammad al-Riyshahrī. (2004/5). Mūsū'ah al-Imām 'Alī ibn Abī Țālib fil-Kitāb walSunnah wal-Tārīkh. Qum: Dār al-Ḥadīth lil-Ṭibā'ah.

Muḥammad al-Tirmadhī. (1983). al-Ṣaḥịh. Beirut: Dār al-Fikr lil-Ṭibā‘ah.

Muḥammad Hasan al-Najafī. (1986/7). Jawāhir al-Kalām fì Sharḥ Sharāyi'al-Islām. Tehran: Dār al-Kutub al-Islāmīyyah.

Muḥammad ibn Ibrāhīm al-Nu'mānī. (2001/2). Kitāb al-Ghaybah. Qum: Anwār al-Hudā. Muḥammad ibn Ismā'īl al-Bukhārī. (1981). al-Ṣaḥịh. Istanbul: Dār al-Fikr lil-Ṭibā‘ah.

Muhammad ibn Jarīr al-Ṭabarī. (1983). Tārīkh al-Ṭabarī. Beirut: Mu'assisah al-A'lamī lil-Maṭbū'āt.

Muhạqiq Hịllī. (1988/9). Sharāyi` al-Islām fì Masā’il al-Halāl wal-Harām. Tehran: Intishārāt Istiqlāl.

Muḥaqqiq al-Karakī. (1987/8). Jāmi 'al-Maqāșid fì Sharḥ al-Qawā ‘id. Qum: Mu’assisah $\bar{A} l$ al-Bayt li Iḥyā' al-Turāth.

Muhaqqiq al-Karakī. (1988/9). Rasā'il al-Karakī. Qum: Maktabah Āyatullāh al-Mar'ash̄̄ al-Najafì.

Mullā Muḥsin Fiỵ̣ Kāshānī. (1980/1). Mafātīḥ al-Sharāyi‘. Qum: Majma‘ al-Dhakhā’ir al-Islāmīyyah.

Mullā Șāliḥ Māzandarānī. (2000). Sharḥ Ușūl al-Kāfì. Beirut: Dār Iḥyā' al-Turāth al'Arabī.

Najm al-Dīn Ja'far ibn Namā Hiillī. (1950). Muthīr al-Aḥzān wa Munīr Subul al-Ashjān. Najaf: Manshūrāt al-Maṭba'ah al-Hiiydarīyyah.

Nașr ibn Muzāḥim al-Minqarī. (1962/3). Waqa'ah Șiffin. Cairo: al-Mu'assisah al'Arabīyyah al-Hadīthah lil-Ṭab'.

Qāọ̄i ‘Aḍid al-Dīn Ījī. (1997). al-Mawāqif fì 'Ilm al-Kalām. Beirut: Dār al-Jīl.

Quṭb al-Dīn al-Biyhaqī. (1995). Iṣbāḥ al-Shī'ah bi Miṣbāḥ al-Sharī'ah. Qum: Mu'assisah al-Imām al-Ṣādiq.

Quṭb al-Dīn al-Rāwandī. (1989). al-Kharā'ij wal-Jarā'ih. Qum: Mu'assisah al-Imām alMahdī.

Sa‘d al-Dīn Taftāzānī. (1981). Sharḥ al-Maqāṣid fì 'Ilm al-Kalām. Pakistan: Dār alMa'ārif al-Nu'mānīyyah.

Sayyid 'Alī Ṭabāṭabā'î. (1998/9). Rìyāẹ al-Masā'il fì Bayān Ahkām al-Shar' bil-Dalā'il. 
Qum: Mu'assisah al-Nashr al-Islāmī al-Tābi ‘ah li Jamā'ah al-Mudarrisīn.

Sayyid al-Khū’'̄. (1992). Mu ‘jam Rijāl al-Hadìth. Unknown: Unknown.

Sayyid Ḥasan al-Bujnūrdī. (1998/9). al-Qawā ‘id al-Fiqhīyah. Qum: Nashr al-Hādī.

Sayyid ibn Ṭāwūs. (1996/7). al-Luhūffì Qatlā al-Ṭufūf. Qum: Anwār al-Hudā.

Sayyid Muḥsin al-Amīn al-'Āmilī. (Unknown). A'yān al-Shī'ah. Beirut: Dār al-Ta'āruf lil-Maṭbū'àt.

Shahīd al-Awwal. (Unknown). al-Qawā'id wal-Fawā'id fĭl-Fiqh wal-Ușūl wal'Arabiyah. Qum: Maktabah al-Mufid.

Shahīd al-Thānī. (1988/9). Haqā'iq al-Imān. Qum: Maktabah Āyatullāh al-Mar'ashī alNajafī.

Shahīd al-Thānī. (1993/4). Masālik al-Afhām ilā Tanqīh Sharāyi" al-Islām. Qum: Mu'assisah al-Ma‘ārif al-Islāmīyyah.

Shaykh ‘Abbās al-Qumī. (2000/1). Nafs al-Mahmūm. Iran: Intishārāt Dhawil-Qurbā.

Shaykh al-Anșārī. (1991/2). al-Taqīyyah. Qum: Mu’assisah Qā’im Āl Muhammad.

Shaykh al-Anșārī. (1994/5). Kitāb al-Ṭahārah. Qum: Mu'assisah al-Hād̄̄.

Shaykh al-Anșārī. (1996). Kitāb al-Makāsib. Qum: Mu’assisah al-Hādī.

Shaykh al-Ḥwayzī. (1991/2). Tafsīr Nūr al-Thaqalayn. Qum: Mu’assisah Ismā'īlīyān li1Țibā'ah.

Shaykh al-Islām al-Juwiynī. (1978). Farā'id al-Simțayn. Beirut: Mu'assisah al-Maḥmūd̄̄ lil-Ṭibā'ah.

Shaykh al-Kashī. (1969/70). Rijāl al-Kashī. Mashhad: Unknown.

Shaykh al-Mufīd. (1989/90). al-Muqni'ah. Qum: Mu'assisah al-Nashr al-Islāmī alTābi'ah li Jamā'ah al-Mudarrisīn.

Shaykh al-Mufīd. (1993). al-Fuṣūl al-Mukhtārah. Beirut: Dār al-Mufīd lil-Ṭibā'ah.

Shaykh al-Mufīd. (1993). al-Irshād. Beirut: Dār al-Mufīd lil-Ṭibā‘ah.

Shaykh al-Mufìd. (1993). al-Masā'il al-'Akbarīyyah. Beirut: Dār al-Mufìd lil-Ṭibā'ah.

Shaykh al-Mufīd. (1993). Awā'il al-Maqālāt fìl-Madhāhib wal-Mukhtārāt. Beirut: Dār alMufĩd lil-Ṭibā'ah. 
Shaykh al-Mufīd. (1993). Kitāb al-Amālì. Beirut: Dār al-Mufìd lil-Ṭibā'ah.

Shaykh al-Mufīd. (1993). Rasā’ il fìl-Ghaybah. Beirut: Dār al-Mufìd lil-Ṭibā‘ah.

Shaykh al-Mufīd. (1993). Taṣhịḥ al-I'tiqādāt al-Imāmīyah. Beirut: Dār al-Mufīd lilȚibā'ah.

Shaykh al-Șadūq. (1959). Ma'ānī al-Akhbār. Qum: Mu'assisah al-Nashr al-Islāmī alTābi‘ah li Jamā'ah al-Mudarrisīn.

Shaykh al-Ṣadūq. (1966). 'Ilal al-Sharāyi'. Najaf: al-Maktabah al-Ḥaydarīyyah.

Shaykh al-Ṣadūq. (1984). 'Uyūn Akhbār al-Ridhā. Beirut: Mu'assisah al-A'lamī lilMaṭbū'āt.

Shaykh al-Șadūq. (1984). Kamāl al-Dīn wa Tamām al-Ni'mah. Qum: Mu'assisah alNashr al-Islāmī al-Tābi‘ah li Jamā'ah al-Mudarrisīn.

Shaykh al-Șadūq. (1993). al-I'tiqādāt fì Dìn al-Imāmīyah. Beirut: Dār al-Mufīd lilȚibā'ah.

Shaykh al-Ṣadūq. (Unknown). al-Tawḥ̄d. Qum: Manshūrāt Jamā‘ah al-Mudarrisīn.

Shaykh al-Ṭūsī. (1973/4). Talkhīṣ al-Shāfì. Qum: Dār al-Kutub al-Islāmīyyah.

Shaykh al-Ṭūsī. (1985/6). Tahdhīb al-Aḥkām. Tehran: Dār al-Kutub al-Islāmīyyah.

Shaykh al-Ṭ̂̄īi. (1989). al-Tibyān fì Tafsìr al-Qur'ān. Unknown: Maktab al-I'lām alIslāmī.

Shaykh al-Ṭūsī. (1991). Kitāb al-Ghaybah. Qum: Mu’assisah al-Ma‘ārif al-Islāmīyyah.

Shaykh al-Ṭ̂̄sī. (1991). Mīṣbāḥ al-Mutahajjid. Beirut: Mu’assisah Fiqh al-Shī‘ah.

Shaykh al-Ṭūsī. (Unknown). al-Nihāyah fì Mujarrad al-Fiqh wal-Fatwā. Qum: Intishārāt Quds Muhammadī.

Shaykh Hādī al-Najafī. (2002). Mūsū 'ah Aḥ̂adìth Ahl al-Bayt. Beirut: Dār Iḥyā' al-Turāth al-'Arabī.

Shaykh Makārim al-Shirāzī. (2008/9). Āyāt Wilāyat dar Qur'ān. Qum: Intishārāt Nasl Jawān.

Shaykh Muḥammad Ḥusayn al-Muẓaffar. (1982). 'Ilm al-Imām. Beirut: Dār al-Zahrā' lilTibā'ah.

Shaykh Muhammad Rị̣ā al-Muẓaffar. (Unknown). 'Aqā'id al-Imāmīyyah. Qum: Intishārāt Anșārīyān. 
Taqī al-Dīn Abī Muḥammad al-Maqrīzī. (1888). al-Nizā' wal-Takhāṣum fìmā bayn Banī Umayyah wa Banī Hāshim. Leiden: Unknwon.

Tha'ālibī, 'Abd al-'Azīz. (1995). Suqūt al-Dawlah al-Umawīyah wa Qīyām al-Dawlah al-'Abbāsīyah. Beirut: Dār al-Maghrib al-Islāmī. 
VITA

\section{SAYED AMIR MIRTAHERI}

Born, Gholhak, Iran

1999-2003

B.Sc., Electrical Engineering Sharif University of Technology

Tehran, Iran

2003-2005

M.A.Sc., Telecomunication Engineering

Simon Fraser University

Vancouver, British Columbia

2006-present

$\mathrm{PhD}$ Candidate with distinction, International Relations Florida International University

Miami, Florida

\section{PUBLICATIONS AND PRESENTATIONS}

Homayounvash, M., and Mirtaheri, S. A. (Forthcoming 2012). Honoring Contracts as a Foundation of Peace: A Shī'ah Articulation. Journal of Religion, Conflict and Peace.

Mirtaheri, S. Amir. (Fall 2010). European Muslims, Secularism and the Legacy of Colonialism. European Journal of Economic and Political Studies: Special Issue on Transnational Islam. 3(Special Issue): 73-86.

Mirtaheri, S. Amir. (Summer 2010). Inexpensive Leadership: On Canada's Global Normative Position and Its Potential. Journal of Military and Strategic Studies. 12(4): 1740 .

Miratheri, S. A. (February, 2010). Non-Linear Modeling of the Characteristic Functions of International Actors Using Artificial Neural Networks. Paper presented at the Annual Convention of International Studies Association, New Orleans, Louisiana.

Mirtaheri, S. A. (April, 2009). The Emerging Otherness of Muslims in Western Europe?. Paper presented at the European Otherness Roundtable, FIU, Miami, Florida.

Mirtaheri, S. A., and Homayounvash, M. (2007). Why Are Contracts Binding? A Comparative Study of Pacta Sunt Servanda in Western Legal Philosophy and Islam. Paper presented at the International Studies Association-South Meeting, Savannah, Georgia. 